\title{
INFLUÊNCIA DO pH E DA NUTRIÇÃO MINERAL NA NODULAÇÃO E FIXAÇÃO DO NITROGÊNIO MOLECULAR PELO FEIJOEIRO (Dhaseolus vulgaris L.), CULTIVADO EM SOLUÇÃO NUTRITIVA
}

LUIZ GONZAGA DA PAZ

Orientador: E. Malavolta

Tese apresentada à Escola Superior de Agricultura "Luiz de Queiroz", da Universidade de São Paulo, para obtenção do título de Doutor em Solos e Nutrição de Plantas.

PIRACICA B A

Estado de Sâo Paulo - Brasıll Agosto, 1978 
DE D I CA TOR IA

"A civilização tem uma grande divida com as leguminosas."

R. MCKEE, 1948

A minha esposa,

Rosete

Aos meus filhos,

Lucia Christina

Sandra Ligia

Luiz Roberto

Simone Maria

Paulo sērgio

Álisson césar

Rosete,

OFEREÇO ESTE TRABALHO 
Ao Prof. E. Malavolta, pela orientação segura, lücidas sugestões e esclarecimentos inestimäveis em todas as etapas des te trabalho;

A Dra. Alaides P. Ruschel, pela co-orientação e participação valiosa e decisiva na condução do experimento;

A Dra. Tsai M. Saito, pelo apoio, sugestões e colaboração;

Aos Prof. Henrique Bergamin Filho, Francisco Krug e Elias G. Zagatto, pela colaboração, através da Seção de Química Ana litica do CENA;

Aos Prof: Henrique Paulo Haag, Murilo Salgado Carneiro, Vidal Pedroso de Faria e Moacyr Corsi, pelo estímulo e entusiasmo transmitidos durante a realização do Curso;

Aos Dr. José Pires Dantas e Boaventura F. Reis, pela coopera ção nas determinações analíticas;

A Dr. Elizabeth Fischer, pelo companheirismo, empenho e dedi cação, sempre presentes na condução do experimento;

Aos Técnicos de Laboratório José Renato de Freitas, Maria An gela Foltran e Yolanda Apárecida Rufini, pela valiosa ajuda nas determinações analíticas;

Ao CNPq (Conselho Nacional de Desenvolvimento Científico e Tecnológico) e ao PEAs (Programa de Educação Agrícola supe rior), pela doação de Bolsas de Estudo, imprescindíveis para a realização dos Cursos de Pós-Graduação; 
Aos Prof: Humberto Carneiro e Naldo Holliday Pires Ferreira, respectivamente, Magnificos Reitor e Vice-Reitor da Universidade Federal Rural do Pernambuco, de cujas decisões me foi possível alcançar tão elevados objetivos;

Ao Departamento de Zootecnia da UFRPE, representado pelos Prof:. Joaquim José Bastos de Faria e Emmanuel Barreto Cam pelo, pela extraordinária visão de educadores;

A Srạ. Isabel Caroni de Gáspari, pelos trabalhos datilográficos.

E a todos que direta ou indiretamente contribuiram para o bom desenvolvimento deste trabalho. 
Pàgina

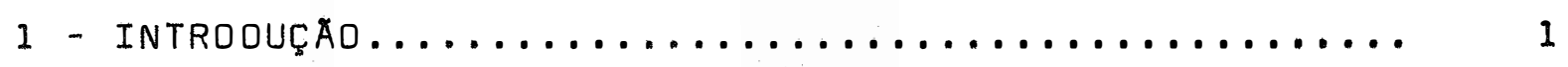

2 - Revisao de literatura............................ 6

2.1 - Aspectos bioquímicos e fisiológicos da nodulação e fixação do nitrogênı.......... 6

2.2 - Caracterização do feijoeiro................ 14

2.3 - Efeito do Nitrogênio combinado.............. 16

2.4 - Efeito do pH, Cálcio e Solução salina......... 18

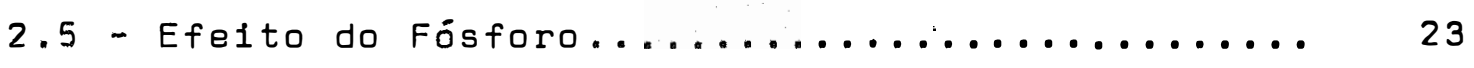

2.6 - Efeito do Alumínio, Ferro, Manganès

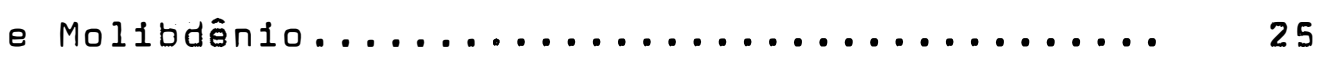

3 - material e metodos...................... 32

3.1 - Instalação dos experimentos.............. 32

3.2 - Variedades estudadas................... 32

3.3 - Estirpes de Rhizobiron utilizadas............ 33

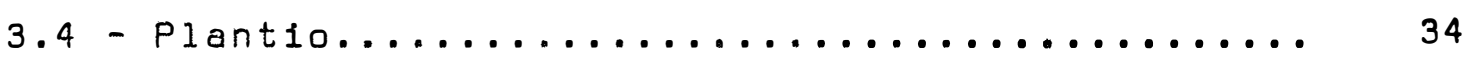

3.5 - Delineamento Experimental............... 35

3.6 - Colheita e preparo do material............ 38

3.7 - Determinação da atividade da nitrogenase..... 39

3.8 - Determinações analíticas dos macro e micronutrientes.................... 39

3.9 - Experimentos realizados................. 40 
4 - RESULTADOS E DISCUSSĂ ................... 47

4.1 - Efeito de nIveis crescentes de N........... 48

4.1 .1 - Peso de Matéria Seca............. 48

4.1 .2 - Nitrogênio absorvido............. 50

4.1 .3 - Nodulação................... 52

4.1 .4 - Atividade da Nitrogenase.......... 53

4.1 .5 - Correlações.................. 55

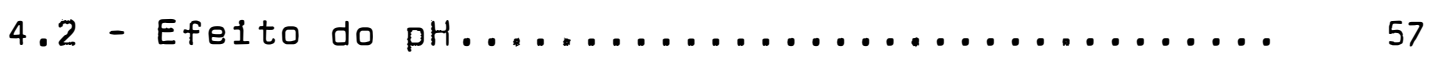

4.2.1 - Peso da Matéria Seca............. 57

4.2 .2 - Nitrogênio absorvido.............. 58

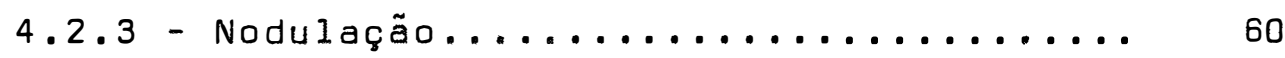

4.2 .4 - Atividade da nitrogenase.......... 62

4.2 .5 - Correlações......................64 64

4.3 - Efeito do Cálcio e Solução salina.......... 65

4.3 .1 - Peso da Matéría Seca.............. 65

4.3 .2 - Nitrogènio e Cálcio absorvidos...... 67

4.3 .3 - Nodulação................... 69

4.3.4 - Atividade da Nitrogenase.......... 70

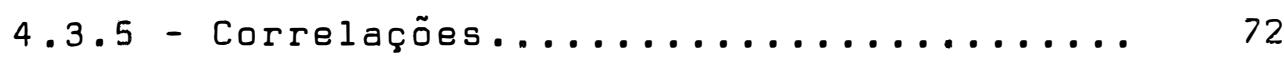

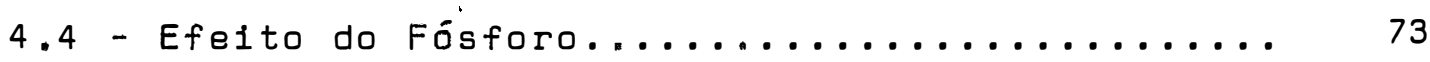

4.4 .1 - Peso da Matéría Seca............. 73

4.4 .2 - Nitrogênio e Fósforo absorvidos..... 74

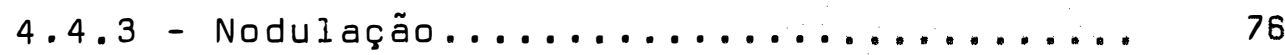

4.4 .4 - Atividade da Nitrogenase.......... 77

4.4 .5 - Correlações.................. 78 
Página

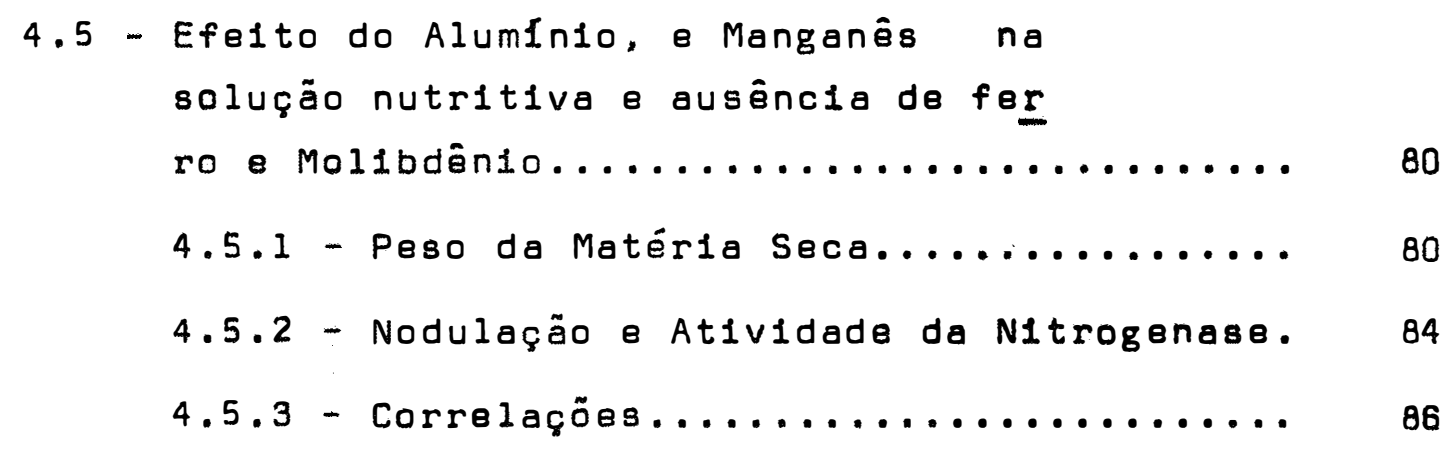

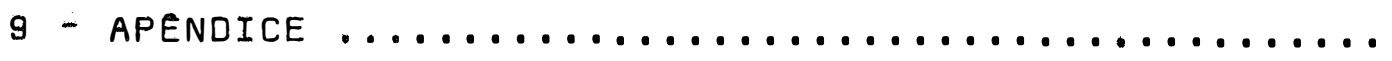


1 - INTRODUÇÃO

o feijoeiro (Phaseolus vulgaris L.) constitui a fonte mais importante de proteína vegetal da alimentação do povo brasileiro, o que explica seu cultivo generalizado por todo o ter ritório nacional (MALAvolta, 1972). Segundo o mesmo autor, no triênio $1967 / 1969$ houve uma queda na produção total, ärea colhí da e rendimento, da ordem de 14,$0 ; 1,0$ e $14,0 \%$, respectivamente, o que tem levado o Brasil a importā-lo em vārias oportunida des, para suprir o consumo interno. Analisando com mais profun didade a cultura do feijoeiro em nosso país, SIMONSEN ASSOCIADos (1976) relataram que o Brasil é o principal produtor mundial de feijão, participando com $20 \%$ do total produzido, mas o rendimento decresceu $20 \%$ entre 1975 e 1960 . O Nordeste apresen ta a maior participação em ärea colhida (40\%) enquanto a Região Sul se destaca com a maior porcentual de produção (37\%). Ainda 
segundo o mesmo relatório, uma projeção feita para 1980, revelou que o rendimento médio do Brasil alcançarā apenas $673 \mathrm{~kg} / \mathrm{ha}$, o que representará um progresso moderado, jā que no período $1967 / 69$ produzimos 698,661 e $606 \mathrm{~kg} / \mathrm{ha}$, decrescendo para 506,9; 523 e $485 \mathrm{~kg} / \mathrm{ha}$ no triênio 1974/76 (BRASIL - Fundação IBGE, 1960; 1976). Em vários países onde o feijão é cultivado, a produção é bastante elevada. Segundo a FAO (1974), no triênio 1972/74, os EE.UU. produziram em média, $1.425 \mathrm{~kg} / \mathrm{ha;}$ o Japão, 1.437; o Egito, 2.166 e o Chile, $1.008 \mathrm{~kg} / \mathrm{ha}$

Não se pode precisar (MALAvolta et alii, 1974) qual o fator ou fatores responsáveis pelos baixos níveis de produtividade do feijoeiro, mas admite-se que mais de um fator limite a produção, podendo variar de região para região. Segundo ARAUJo, citado por GRAHAM e HALLIDAY (1976), cerca de 65 a $70 \%$ das sementes de soja plantadas no Brasil são inoculadas, enquanto para o feijão não alcança 0,5\%. Respostas do feijoeiro à inocula ção são constantes, conforme registros da literatura, muito embora a porcentagem de células dos nódulos infectados pelo Rhizo bium seja inferior à soja e ao amendoim (VINCENT, 1974), e a atividade específica dos nódulos alcance menos da metade dos níveis alcançados pela soja (HARDY et alii, 1968). Em Madagascar (VUONG HUI HAI, citado por GRAHAM e HALLIDAY, 1976) a inoculação permitiu elevar a produção do feijoeiro de 1.272 para 2.315 $\mathrm{kg} / \mathrm{ha}$; no Sudão (HABISH e ISHAG, 1974) houve registros significativos, quando a inoculação permitiu eleva-la de 793 para 1.943 $\mathrm{kg} / \mathrm{ha}$. 
A queda da produtividade do feijoeiro vem repercutindo no consumo per-capita, haja visto que em 1971 o Brasil consumiu $26,4 \mathrm{~kg} / \mathrm{ano}$, caindo em $1975 \mathrm{para} 19,8 \mathrm{~kg} / \mathrm{per}$ capita/ano. E sabido que há uma correlação positiva entre renda per-capita e consumo proteína, sendo que nas camadas de baixa renda o consumo de proteína cresce em função do aumento do consumo de produtos de origem vegetal, tais como, cereais, tubérculos e leguminosas (SIMONSEN ASSOCIADOS, 1976). Por outro lado, pesquisa de àmbito nacional realizada por MALDONADO NEVES (1971), comprovaram que o feijão é o alimento mais consumido no Brasil $(98,5 \%)$, seguindo-se o $\operatorname{arroz}(91,4 \%)$, o pão $(90 \%)$ e o café $(88,2 \%)$.

A demanda proteica, particularmente pelo feijão exig rá até o final do século maiores atenções dos pesquisadores, jā que teremos segundo FURTADO (1974) mais de 225 milhões de habitantes, se for mantido nos próximos decênios o atual ritmo de crescimento demográfico (2,4\%/ano). Admitem mesmo os geneticis tas e nutricionistas, que o aumento da produtividade do feijoe ro deve se constituir em meta prioritäria, uma vez que ajustados e agilizados os mecanismos de oferta e demanda, o consumo per-capita possivelmente elevar-se-ia. Tal fato contribuirá de cisivamente para minimizar aspectos sócio-econômicos relevantes, tais como, mortalidade infantil e esperança de vida de ponder $\overline{-}-$ vel parcela da população brasileira. 
o feijoeiro responde bem à adubação nitrogenada e tem apresentado um número relativamente alto de respostas ao nitrogênio (MIYASAKA et alii, 1963 ; FONTES, 1972 ; PONS, 1975 ; CHA GAS e VIEIRA, 1975 ; DUTRA et alii, 1975).

Tais resultados sugerem que a leguminosa nas condições brasileiras não fixa eficientemente o $\mathrm{N}_{2}$ atmosférico, o que pode ser explicado através de vārias hipóteses: ineficiência pa ra a simbiose; populações de Rhizobium não eficientes; condi ções de clima e solo inadequadas; combinação de todas essas hipóteses.

Värios autores (MASEFIELD, 1968 e 1971 ; EDJE et a $i$ i, 1975) admitiram influência da presença de antibióticos quando da inoculação da semente, retardamento das atividade do Rhizobium no florescimento, curto período de crescimento do feijoeiro. RUSCHEL et alii (1977) encontraram provas de que parte do $\mathrm{N}_{2}$ fixado pode ser excretado pela planta, exigindo novo suprimento de energia para ser reabsorvido, depois de submeterem a planta ao $15_{\mathrm{N}}$.

Näo obstante todos esses relatos, RAGGIO et alii (1959) comprovaram a fixação do nitrogênio, expondo nódulos do feijoeiro ao ${ }^{15} \mathrm{~N}$. RUSCHEL e RUSCHEL (1975) observaram efeito da variedade na simbiose Rhizobium-feijoeiro, avaliando a fixação através do peso, teor de $N$ e atividade da Nitrogenase.

o objetivo do presente trabalho foi estudar em três variedades de feijoeiro, Carioca, Rico-23 e Venezuela 350 , cul- 
tivadas em solução nutritiva, sob condições controladas, a influência de alguns fatores que afetam a nodulação e fixação do nitrogênio molecular, a saber:
a) - Níveis de $\mathrm{N}$ combinado;
b) - $\mathrm{pH}$; níveis de Calcio;
d) - Níveis de Fósforo;
e) - Níveis de Alumínio;
f) - Níveis de Manganês;
g) - Ausência de Ferro e Molibdênio;
h) - Salinidade. 
2.1 - Aspectos bioquímicos e fisiolögicos da nodulação e fixação do ni trogênio

A rotação de culturas através do uso alternativo de plantas leguminosas e não leguminosas é uma prática muito antiga. Os benefícios decorrentes do seu emprego não eram conheci dos, mas, empiricamente, observavam os povos que viviam da agri cultura, sensivel melhoramento, das colheitas e condições do solo, até que em i830, BoUSSINGAULt ofereceu uma explicação para o caso. Através de experimentos realizados em casa de vegetação com trevo e ervilha, pode observar aumento dos seus teores de nitrogênio, embora vegetassem em areia, livre desse elemento, o que confirmou hipótese de que as leguminosas usavam $\circ \mathrm{N}_{2}$ do ar atmosfērico. Posteriormente, HELLRIEGEL e WILFARTH confirmaram 
tais resultados na Alemanha, publicando-os em 1888. Estes pesquisadores estabeleceram assim a realidade da fixação biológica do $N$, e demonstraram sua associação com nódulos existentes nas plantas leguminosas, o que significava claramente que os nódulos foram induzidos por microrganismos Convertendoo $\mathrm{N}_{2}$, gás inerte, numa forma utilizävel, estes microrganismos suprem parte das necessidades vitais da planta em $N_{2}$ obtendo em troca, carboidratos solúveis que serão usados como fonte de energia na sintese de novos tecidos. Um gênero simples de bactéria, o Rhi zobium, é responsável por esse evento.

- Rhizobium è uma bactēria que pertence à família Rhi zobiaceae, bastante regular, móvel quando jovem, gram-negativa, que mede 1,2 a $3,0 \mu \mathrm{m}$ de comprimento e 0,5 a $0,9 \mu \mathrm{m}$ de 1 argura, heterotrófico, aeróbio. Estirpes isoladas de leguminosas tropi cais toleram temperaturas mais elevadas ( 30 a $429 \mathrm{C})$, mas em geral, desenvolvem-se melhor entre 25 e 30 ọ, e variação de $\mathrm{pH}$ entre 6,0 e 7,0 (VINCENT, 1974 e 1975). Uma série de fungos, Pseudomonas spp. e actinomicetos podem funcionar como seus anta gonistas, enquanto outros microrganismos do solo favorecem seu desenvolvimento (VINCENT, 1974). O Rhizoḅium pode viver livremente no solo como um heterotrófico aeróbio, mas também simbioticamente no nódulo, sob condições quase anaeróbias (KLECKKOWSKA et alii, citados por NUTMAN, 1972).

A invasão das raízes pelo Rhizobium ocorre de värias maneiras; às vezes a infeção se dá diretamente através da pare de celular, mas, frequentemente, as bactérias invadem-os pelos 
radiculares que säo projeçöes das paredes celulares, assumindo uma forma não reprodutiva, chamada bacteróide, que é o fixador ativo do nitrogênio (HAUSENBUILLER, 1975). Um componente genético governa a compatibilidade entre o Rhizobium e a planta hos pedeira (EPSTEIN, 1975), caso contrário não corre a nodulação ou se desenvolvem nödulos pouco eficientes. Estimuladas por metabōlitos orgânicos excretados pela raiz (ROVIRA, 1969) as bactérias se congregam na rizosfera, podendo converter o tripto fano em ácido indol-acético (AIA) por descarboxilação e deamina ção (GIBSON, 1977). Além do AIA, uma proteína ou polissacarí deo, e um ácido nucleico podem ser responsāveis pela ramificação e encurvamento dos pelos radiculares (GIBSON, 1976 ; Ranga RAO, 1977 ; GIBSON, 1977). O filamento de infecção apresenta estrutura membranosa, contém celulose e pectina e sua forma pode ser múltipla, ramificada, tuberculada, afunilada, ou ainda como um disco (DART, 1974 ; EPSTEIN, 1975 ; RANGA RAO, 1977).

A nodulação é influenciada por fatores químicos, externos, e endógenos, além do AIA, ácido abscíssico, PHILLIPS, cí tado por DART (1974), e ainda o fitocromo, cujo papel no flores cimento e germinação é relevante (LIE, 19699 e 1971). Segundo GIBSON (1977), dois tipos de nódulos podem ser formados, meristemáticos que são comuns em muitas leguminosas temperadas e nódulos esfēricos, não meristemáticos, mais comuns nos trópicos. os nódulos estão em conexão direta com o sistema vascular da planta e alguns possuem quantidades consideráveis de hemoglobina (LEHNINGER, 1975) resultante do complexo leguminosa - Rhizo- 
bium, muito embora nenhum dos dois organismos cultivados isoladamente a possuam (ALlEN e ALlen, citado por DEVLIN (1975). Há provas da sua existência em leveduras e outros fungos (APPLEBY, 1974). Segundo virtanem e miettinem (1963), nódulos sem hemoglobina não fixam nitrogênio, havendo, segundo vārios autores (JORDAM e GARRARD ; GRAHAM e PARKER, citados por APPLEBY, 1974), cO $\underline{r}$ relação entre a concentração de hemoglobina e a fixação. A prin cipal função da hemoglobina (BERGERSEN, 1971,1973; SKINNER, 1976) parece ser a de facilitar o suprimento de oxigênio para os bacteróides fixadores de nitrogênio. A sequência de reações que conduzem ao aparecimento dos nódulos, foi estudada em Medicago sativa por MUNNS (1968a), que destacou os seguintes eventos:

a) - Desenvolvimento dos pelos radiculares;

b) - Desenvolvimento de uma população de Rhizobium próximo à superfície das raízes, na rizosfera;

c) - Encurvamento e infecção dos pelos radiculares;

d) - Desenvolvimento do filamento de infecção;

e) - Formação dos nódulos.

A fixação biológica do N é catalisada por uma enzima chamada nitrogenase, composta por duas proteinas: uma de maior peso molecular, contendo Fe e Mo, chamada Mo-Fe-Proteina, e outra mais leve, contendo apenas Fe, chamada Fe-Proteina. Segundo HARDY et alii (1975), ambos os componentes são essenciais pa ra a atividade da nitrogenase na relação de 1 ou 2 Ferro-Protei 
nas para cada Mo-Fe-Proteina, sendo sua atividade regulada pela relação ATP/ADP. O suprimento de ATP sempre excede a demanda (HALLIDAY, 1976), e apenas 25 a $40 \%$ do trifosfato de adenosina (ATP) gerado na respiração do nódulo, parece ser necessário para a atividade da nitrogenase, permanecendo 60 a $75 \%$ disponível para os processos biosintéticos, enquanto pequena parte é gasta na evolução de $\mathrm{H}_{2}$. Ainda segundo o mesmo autor, para produzir 1 mg de $\mathrm{N}$ através da fixação simbiótica, $9,4 \mathrm{mg}$ de carbono seriam utilizados pelas raízes e $4,1 \mathrm{mg}$ pelos nódulos. Com obser vações de natureza teórica, BERGERSEN (1971) postulou que a fixação de $\mathrm{N}_{2}$ atmosférico exige $1,3 \mathrm{mg}$ de carbono para cada mg de N fixado. GRAHAM e HALLIDAY (1976) conduzindo estudos em Phaseolus vulgaris, verificaram existir concentrações de carboidra tos solúveis nos nódulos, correspondentes a 0,3 a $2,6 \%$ do peso da matéria fresca, enquanto as raízes, caules e folhas apresentaram respectivamente, $0,7 / 1,8 \% ; 0,4 / 1,4 \%$ e $0,6 / 2,7 \%$.

o primeiro produto estável da fixação do nitrogênio é a amônia, excretada pelos bacteróides logo depois de fixada. Se bem que os dados indiquem que $\mathrm{N}_{2}$ é inicialmente convertido a $\mathrm{NH}_{3}$, e difícil acreditar que a reação total envolvendo a adição de 6 elétrons aos dois átomos de $N$, não envolva intermediários. Segundo BERGERSEN (1973), o nitrogênio surge inicialmente como ácido glutâmico, seguindo-se a serina, a treonina ou asparagina e o $\mathrm{NH}_{3}$. HARDY et alii (1975) também identificaram a asparagina na soja, ao lado do ácido aspártico e do ácido glutâmico, enquanto outros autores (KURZ et ali $i$ e ROBERTSON et ali $i$ citados 
por GIBSON, 1977) admitiram que a sintetase da glutamina (GS) é responsável pelo primeiro passo na assimilação da amônia. Estü dos mais recentes admitem duas vias de assimilação do íon amonio pelas células vegetais: a via GDH, ou seja, através da mediação inicial da deshidrogenase glutâmica, e a via GS/GOGAT, ou seja, através da ação das enzimas sintetase de glutamina, sinta se glutâmica, transminase e sintetase da asparagina (MIFLIN e LEA, 1976 ; SCOTT, 1978). O estudo da assimilação e movimento do nitrogênio nos nódulos permitiu a alguns autores (MIFLIN e LEA, 1976) relatarem que $70 \%$ do $N$ encontrado na corrente de transpor te estava sob a forma de asparagina; $13 \%$ como glutamina; $4 \%$ como ácido glatâmico e $13 \%$ sob a forma de outros aminoácidos.

Em 1965, SCHOLLHORN \& BURRIS, pesquisadores da Univer sidade de Wisconsin, e DILLWORTH da Universidade de Murdoch, Aus trália, demonstraram que o acetileno inibia a atividade da nitrogenase, e, posteriormente comprovaram que a enzima reduzia o acetileno $\left(\mathrm{C}_{2} \mathrm{H}_{2}\right)$ a etileno $\left(\mathrm{C}_{2} \mathrm{H}_{4}\right)$ (BRILL, 1977). Logo depois, KoCH e EVANS (1966) utilizaram o método de redução do acetileno para medir a atividade da nitrogenase em nódulos destacados de soja. O método de redução do acetileno, segundo HARDY et alii (1973) é mil a dez mil vezes tão sensível quanto o método em que é utilizado o ${ }^{15} \mathrm{~N}$, apresenta facilidade operacional muito maior, o que permite a realização de 30 medições/homem $x$ hora no campo e 20 análises de cromatografia gasosa/homem x hora em laboratório. Afirmaram ainda esses autores que o $\mathrm{CO}_{2} \bar{e}$ um potente inibidor da redução do acetileno pela nitrogenase, que é afe tada, principalmente, pelo $\mathrm{N}$ combinado, temperatura, $1 \mathrm{uz}, \mathrm{p}_{2}$, $\mathrm{N}_{2}, \mathrm{PC}_{2} \mathrm{H}_{2}$ e àgua. 
Devido à presença da reductase de nitrato na bactéria, muitos nódulos apresentam atividade dessa enzima (GIBSON, 1977). o nitrito produzido, um inibidor da nitrogenase, pode ser responsável pela inibição da fixação do nitrogênio em plantas nodu ladas expostas ao nitrato (GIBSON e PAGAN, 1977), como também em bacteröides extraidos dos nódulos (RIGAUD et alii, 1973), em cul turas de Rhizobium (PAGAN et alii, citados por GIBSON e PAGAN, 1977), e da enzima cultivada "in vitro" (KENNEDY et alii, 1975).

A baixa eficiência fotossintētica de leguminosas domesticadas é a maior limitação para a fixação biológica do N, e provavelmente, para a sua utilização (HARDY et alii, 1975). Se gundo GIBSON (1977) alta intensidade luminosa, tem sido responsabilizada pela "fome de N" verificada em leguminosas que vegetam em solos onde o nível de Nitrogênio é baixo. Admitem värios autores (GROBELAAR et alii, 1971; DART, 1974), que tanto - comprimento do dia, como a intensidade luminosa afetam o núme ro e a distribuição dos nódulos. Dentro de certos limites (LIE, 1971 e 1974), pode se verificar uma correlação direta entre intensidade luminosa e nodulação, e ainda, fixação de $N$, muito em bora o desenvolvimento dos nódulos e a fixação de $N$ sejam mais dependentes da luminosidade para o suprimento de carboidratos, do que o processo de infecção em si.

Reduções de temperatura, tanto diurna como noturna, a fetam a capacidade fotossintética do feijoeiro (DALE, 1964 ; JO NES, 1971). Temperaturas elevadas afetam a formação do nódulo 
e a fixação de $N$, entretanto valores considerados altos para a simbiose, podem não atender às exigências da planta hospedeira, dependendo do nível de $N$ presente.

Em geral, afirmou GIBSON (1976), plantas supridas com $N$ combinado, reagem melhor às elevaçōes de temperatura entre 5 e 209C, do que plantas noduladas.

Admitiram värios autores (FERRARI et alii, 1967 ; HABISH, 1970 ; SOUTO e DOBEREINER, 1970), que leguminosas tropicais e subtropicais apresentam níveis satisfatórios de $\mathrm{N}$ fixado, sob temperaturas máximas entre 27 e $409 \mathrm{C}$. Segundo outros auto res (DART e MERCER, 1965 ; GIBSON, 1971) temperaturas inferiores a $209 \mathrm{C}$ afetam a simbiose em leguminosas tropicais.

Segundo LIE (1971), a planta exige temperaturas mais elevadas no segundo ou terceiro dia após a inoculação. Em outro relato, o mesmo autor (LIE, 1974) afirmouque o efeito da temperatura é mais importante quando incide sobre a raiz do que sobre a parte aérea.

o oxigênio é necessārio aos nōdulos, participando da fosforilação oxidativa, reação que fornece a energia necessāria à redução de $\mathrm{N}$ a $\mathrm{NH}_{3}$, mas a absorção de $\mathrm{N}$ não e afetada pelo au mento dos níveis de $\mathrm{CO}_{2}$ na atmosfera (GIBSON, 1977).

Um baixo potencial da água do solo afeta a fixação do nitrogênio devido à inibição da fotossintese (HUANG et alii, em GIBSON, 1977) mas dentro de certos limites, os nódulos poderão 
recuperar sua atividade com o reumidecimento (PANKHURST e SPRENT, SPRENT, citados por GIBSON, 1977).

o desfolhamento remove a principal fonte de produtos da fotossintese para os nódulos, e de acordo como maior ou menor grau de severidade, entram em jogo variāveis morfológicas e fisiológicas importantes (PAZ e LOBÃO, 1976), que influenciadas pelas condições ambientais, afetarão o nümero e peso médio dos nódulos, além da fixação do nitrogênio (WhIteman, 1970 ; Rogers, 1969 ; GIBSON, 1977 ).

\section{2 - Caracterização do feijoeiro}

o feijoeiro (Phaseolus vulgaris L.) é uma leguminosa nativa da América Central, e foi domesticado hä 7.000 anos atrás (KAPLAN, citado por FROUSSIOS, 1970). Seu sistema radicular é fibroso, com muitos nódulos pequenos localizados principalmente nas raízes secundárias, o que difere da maioria das le guminosas, que apresenta raiz primária, tendo ao seu redor os nodulos principais (KAMATA, citado por GRAHAM e HALLIDAY, 1976). o crescimento inicial do feijoeiro é muito lento até os 20 dias, intensifica-se aos 30 e atinge o nível mäximo aos 50 dias (HAAG et alii, 1967). Exige, segundo os mesmos autores, elevadas quantidades de nitrogênio, jā que uma população de plantas cor respondente a um hectare absorve $201 \mathrm{~kg}$ de $\mathrm{N}$.

Vārios pesquisadores tem se preocupado com a adoção de práticas agronômicas e estudos de melhoramento genético vi- 
sando elevar sua produtividade. ADAMS (1973) propôs modificações em sua "arquitetura" vegetal, concebendo um ideótipo para - sistema de monocultura, com ciclo de 100 dias e uma população de 500.000 plantas/hectare. O Centro Internacional de Agri cultura Tropical (CIAT, 1975) preconizou o uso de "tutoramento" e obteve com variedades trepadoras, $5.600 \mathrm{~kg} / \mathrm{ha}$ em $96 \mathrm{dias}$ com população em torno de 1.000 .000 de plantas/ha, método também pro posto por pesquisadores nacionais (PRADO et atii, 1976).

0 feijoeiro tem apresentado elevados niveis de $\mathrm{N}_{2}$ $\left(\mathrm{C}_{2} \mathrm{H}_{2}\right)$ fixado. GRAHAM e HALLIDAY (1976) relataram que níveis de 38 moles de $\mathrm{C}_{2} \mathrm{H}_{4}$ /hora/planta tem sido encontrados, e valores superiores a 20 moles de $\mathrm{C}_{2} \mathrm{H}_{4}$ são comuns, embora as respos tas à nodulação no campo sejam extremamente variáveis. Segundo os mesmo autores, JANSSEN e VITOSH obtiveram apenas 6 moles de etileno/planta/hora, enquanto SPRENT, em vários ensaios realiza dos em casa de vegetação, obteve 1,5 m moles. A.atividade específica dos nódulos apresenta igualmente valores muito variáveis, desde 10,51 a $31,89 \mu$ moles $\mathrm{C}_{2} \mathrm{H}_{4} / \mathrm{g}$ de matéria seca nodular aos 50 dias (RUSCHEL e SAITO, 1977) a 130 a 250 pmoles de etileno por grama de matéria seca dos nódulos obtidos por outros autores (GRAHAM e HALLIDAY, 1976) entre os 32 e 67 dias de idade, com diferentes cultivares de Phaseolus vulgaris.

o feijoeiro apresenta elevado teor proteico, situando-se segundo vários autores (RUTGER, 1970 ; ORTEGA et alii, 1974 ; TULMANN NETO, 1975) entre 17,9 e $37,6 \%$. Seu valor nutri cional é todavia comprometido pela baixa digestibilidade de 
sua proteina (KALDY, 1972 ; BOULTER, 1977), fatores anti-metabó licos e baixo teor de alguns aminoácidos essenciais (HELLENDOORN, 1969 ; BRESSANT et alii, 1973 ; ORTEGA et alii, 1974 ; TULMANN NETO, $1975 ;$ BOULTER, 1977).

\section{3 - Efeito do Nitrogênio combinado}

Vinte anos antes da descoberta da função dos nódulos, ou seja, em 1864, RAUTENBERG e KUHN observaram que a amônia e o ní trato inibiam a nodulação (RAGGIO et alii, 1965). Em geral, a fixação do nitrogênio é inibida pelo amoníaco ou por compostos facilmente convertidos em amoníaco, tais como nitrato, nitrito, ureia e aminoácidos (DEVlin, 1975 ; MALAVolta, 1976). O grau de inibição depende, segundo LIE (1974), da concentração e forma de $N$ combinado, tempo da aplicação, condições de crescimento e tipo da planta hospedeira, além da estirpe de Rhizobium empre gada, jă que a origem e características individuais da estirpe (VINCENT, 1974), influenciam o nümero e o peso médio dos nódulos. Vários autores admitem (TONHAZY e PELCZAR JR., 1954 ; TANNER e ANDERSON, 1964) que a destruição catalïtica do ácido indolacéti co (AIA) pelo nitrato seria responsável pela inibição da nodula ção, mas o mecanismo que envolve a ação do AlA sobre a nodulação, segundo värios pesquisadores (KEFFORD et alii, 1960 ; TANNER e ANDERSON, 1963) não está bem claro. Sendo o nitrito um inibidor da nitrogenase, sua possível produção no tecido nodular sob a ação da reductase de nitrato, provavelmente, segundo 
alguns autores, influencia a fixação do nitrogênio, inibindo-a, em plantas expostas ao nitrato (KENNEDY et ali $i, 1975$; GIBSON e PAGAN, 1977). Esta hipótese, reduziria o papel do nódulo na translocação de produtos da fotossintese foi afastada em: recen te pesquisa efetuada por GIBSON e PAGAN (1977). Estes autores adicionaram $\mathrm{NO}_{3}$ à mutantes deficientes em reductase de nitrato, e verificaram que a inibição da atividade da nitrogenase foi semelhante à estirpe não deficiente.

Outros pesquisadores postularam que a inibição decorre em função da redução do suprimento de produtos da fotossinte se utilizados pela raiz e parte aérea em decorrência da assimilação do nitrato (SMALL e LEONARD, 1969 ; OGHOGHORIE e PATE, 1971). A adição de elevados teores de nitrogênio afetam inicialmente o nümero e o peso dos nódulos, mas não inibem o seu desenvolvimento e a fixação simbiótica do nitrogênio (RUSCHEL et alii, 1974 ; RUSCHEL e RUSCHEL, 1975 ; RUSCHEL e SAITO, 1977).

Se pequenas quantidades de nitrogênio, como dose de "arranque", são oferecidas de modo a permitir um aumento do cres cimento dos nódulos, mais $N$ poderā ser fixado pela planta (PATE e DART, 1961 ; MUNNS, 1968a; DART e WILDON, 1970 ; LONERAGAN, 1972). Alguns autores atribuem o efeito benéfico da "dose de arranque", de $N$ combinado ao melhor crescimento inicial da planta, e à disponibilidade de aminoācidos livres para o de senvolvimento dos nódulos, quando presentes nas raízes, e para a sintese da clorofila, quando presente na parte aérea (GIBSON, 1976 ; GIBSON, 1977 ). 
A hipótese de que a relação C/N governava a formação do nódulo e a fixação do nitrogênio defendida por alguns autores (VAN SCHREVEN, 1959 ; CARTWRIGHT e SNOW, 1962), que afirmavam que quanto mais ampla, maior seria a fixação, foi afastada por outros pesquisadores (RAGGIO et alii 1957 ; CARTWRIGHT, 1967, GROBELAAR et ali $i, 1971$ ). Segundo tais autores, o efeito adver so se devia à acumulação de compostos nitrogenados e redução do nível de carboidratos dentro do tecido da raíz e não a um efeito local de algum composto nitrogenado em particular.

Segundo LONERAGAN (1972), são necessärias concentrações muito elevadas de nitrogênio, $4 \mathrm{mM}$ de $\mathrm{NO}_{3}{ }^{-}$, para inibir completamente a nodulação. Outros autores (RAGGIO e RAGGIO, 1962) relataram que o nitrato administrado em doses iguais ou inferiores a $1,0 \mathrm{mM}$ estimulam a nodulação. Estes dados estão de acordo com as observações de MUNNS (1968a) estudando a leguminosa Medicago sativa. Com $0,02 \mathrm{mM}$ de $\mathrm{NO}_{3}^{-}$a nodulação foi inibida, e concentrações mantidas entre 0,2 e $0,5 \mathrm{mM}$ reduziram drasticamente o número de nódulos na primeira colheita, mas nas colheitas subsequentes o efeito foi muito reduzido ou quase nu 10 (MUNNS, 1968a).

2.4 - Efeito do pH, Cälcio e Solução salina

No estudo do efeito do $\mathrm{pH}$ temos que distinguir entre a ação direta dos iônios hidrogênio e o seu papel indireto, tra duzido por alterações na disponibilidade dos el'mentos essenciais 
existentes no solo (MALAVolta, 1967). Nos solos äcidos, iônios como Al, Fe, Mn, Cu e $\mathrm{Zn}$, podem ser encontrados em quantidades tóxicas às plantas (MALAVolTA, 1976). Com relação às leguminosas em particular, relatou VICENT (1965), que a atividade dos ions $\mathrm{H}^{+}$é o fator que mais restringe a sobrevivência e o crescimento do Rhizobium no solo. Vários autores admitiram que o feito nocivo da acidez sobre as leguminosas tem sido reconhecido hā muitos anos, no entanto, afirmam (LIE, 1969b; LONERAGAN, 1972 ; MUNNS e FOX, 1977) que o grau de tolerância varia entre as estirpes de Rhizobium.

Segundo VICENT (1965), tipos de bactérias de crescimento lento, tais como Rhizobium japonicum e Rhizobium Zupini, são mais tolerantes do que aquelas que apresentam rápido crescimento, como o Rhizobium melizoti. Em outro relato do mesmo autor (VICENT, 1974), foi apresentada a sequinte sequência em relação à tolerância da bactēria à acidez: Rhizobium Zeguminosarum > Rhi zobium trifolii > Rhizobium phaseoli > Rhizobium meliloti.

Relatou ANDREW (1977) que os principais fatores que interferem na reação das leguminosas à acidez são:

a) - Sobrevivência e crescimento do Rhizobium no solo;

b) - Infecção da raiz e formação do nódulo;

c) - Eficiência simbiótica leguminosa-Rhizobium;

d) - Nutrição da planta hospedeira.

O papel desempenhado pelo pH no processo de infecção e posterior nodulação não estā claramente esclarecido (ANDREW, 1977). A inibição da atividade enzimática da pectinase na fai- 
$x a$ de $\mathrm{pH}$ entre 4,5 e 5,5 cuja relevância foi defendida por MUNNS (1969), posteriormente foi contestado por outros autores (LILLICH e ELKAN, citados por LIE, 1974 ; SOLHEIM e RAA, 1971). Outros pesquisadores observaram influência da morfologia dos pelos radiculares, formação de uma camada de mucilagem protegendo a bactéria sob condições de neutralidade, e forte interação $p H$ x Ca (MUNNS, 1968b; LIE, 1969b e 1974 ; LOWTHER e LONERAGAN, 1970).

As leguminosas tropicais toleram a acidez do solo ou a deficiência de cálcio melhor do que as leguminosas temperadas (ANDREW e NORRIS, 1961 ; NORRIS, 1965 ; MUNNS e FOX, 1977). Es sa afinidade simbiótica tolerante à acidez que caracteriza as leguminosas tropicais está relacionada à sua associação com estirpes promíscuas originärias do grupo cowpea (NORRIS, 1967). Ad mite DOBEREINER (1971) que as dificuldades no estudo de leguminosas de nodulação promíscua, são recompensadas pela disponibiidade de estirpes de Rhizobium que produzem nódulos pretos. Em Phaseolus vulgaris, STAMFORD et alii (1968) encontraram nódulos pretos quando inocularam o feijoeiro com uma estirpe "preta" isolada de Mimosa caesalpiniaefolia Benth.

Segundo MUNNS et alii (1977), o feijoeiro (Phaseolus vulgaris) quando submetido aos valores de $\mathrm{pH} 4,7 ; 5,5 ; 6,3$ e 7,1 aumentou o teor de $N$ e o número de nódulos em pH 6,0 mas sem haver correlação com o crescimento. Na faixa de pH superior a 6,0 os autores verificaram que o feijoeiro aumentou o crescimen to, mas não houve um aumento corresponde em número e peso dos 
nódulos, mas houve sim uma redução de 4 a $5 \%$ no teor de $N$ nas folhas. Na Nigéria, Centrosema pubescens apresentou produções de matéria seca mais elevadas na faixa de pH entre 6,1 e 7,4 ao passo que stylosanthes gracilis apresentou melhor desempenho nos pHs situados entre 5,7 e 6,0 .

Um baixo suprimento de Ca disponível é um carolärio da acidez do solo, mas quando existem tratamentos de pH e Cálcio, com interação entre ambos, o efeito relativo do pH frequen temente predomina sobre o efeito do cálcio (ANDREW, 1977). Observou todavia o autor, que na faixa intermediária de pH, o pro blema está condicionado às concentrações de câlcio usadas no experimento. Quando a leguminosa é cultivada em presença de $N$ combinado (MALAVOLTA, 1976), tanto o processo de infecção como a formação dos primeiros nódulos exigem uma concentração de Ca maior do que a necessária. Estirpes de Rhizobium trifolii apre sentaram alterações morfológicas em concentrações de Ca iguais ou inferiores a $1 \mathrm{ppm}(0,025 \mathrm{mM} / 1$ itro) (LONGERI e ALLEN, 1970). Segundo os mesmos autores, a concentração de Mg necessāria ao crescimento do Rhizobium não deve ser inferior a $1 \mathrm{ppm}(0,04 \mathrm{mM} / 1)$.

Segundo LOWTHER e LONERAGAN (1970), Trifolium subterraneum aumentou três vezes a porcentagem de plantas noduladas e treze vezes o número de nódulos/planta, quando a concentração de cálcio foi elevada de 35 para $700 \mu \mathrm{M}$. Afirmaram ainda os autores, que o processo de infecção pode ocorrer livremente com 250 $\mu \mathrm{M}$ de $\mathrm{Ca}$ e $\mathrm{pH} 5,0$ mas os nódulos só aumentarão de tamanho se as plantas receberem concentrações de cálcio mais elevadas. 
Relataram ANDREW e JOHNSON (1976) que as leguminosas Macroptilium Zathyroides e Lotononis bainesii não foram efetadas pelas concentrações de Ca estudadas $(0,125$ e 2,0mM) e apresentaram nodulação total ( $100 \%$ das plantas). Por outro lado, Stylosanthes humilis e Lotononis bainesii apresentaram as maiores produçóes de matéria seca com o nível mais baixo de Ca, isto é $0,125 \mathrm{mM}$. Segundo SAITO e RUSCHEL (1976), a calagem por si só, ( 1 t de $\mathrm{CaCO}_{3} / \mathrm{ha}$ ) não afetou o peso e o nitrogênio total de Phaseolus vulgaris. Com 2,0 t de $\mathrm{CaCO}_{3} / \mathrm{ha}$, RUSCHEL et alii (1966) verificaram que o número de nódulos do feijoeiro aumentou mais de 5 vezes, enquanto que o peso da planta somente foi duplicado.

As leguminosas que vegetam em condições ambientais sạ Iinas apresentam crescimento reduzido (BERNSTEIN e OGATA, 1966; IMBAMBA, 1973). A sensibilidade da raíz à salinidade pode afetar não somente o desenvolvimento das raízes, mas também o meta bolismo nas folhas devido a alteraçōes no balanço hormonal (BEN zIONI et alii, 1967). Segundo MALAVOLTA (1976) e TERRY (1977), - cloro é necessārio para a operação do fotosistema II da fotos síntese, ou seja, para a decomposição fotoquímica da água que é acompanhada pela libertação de $0_{2}$. Relataram LAHAyE e EPSTEIN (1971) que o feijoeiro é normalmente sensível a elevadas concen trações de NaCl, mas desenvolveu-se bem em solução nutritiva con tendo $50 \mathrm{mM}$ de cloreto de sódio, mas com suficiente quantidade de cálcio. 
AYOUB (1974) estudou em solução nutritiva a eficiência do cálcio à tolerância de Phaseolus vulgaris ao meio salino, verificando que concentrações de 20 e $40 \mathrm{mM}$ de $\mathrm{Na} \mathrm{Cl}$, na au sência de Ca, resultaram em redução da parte aérea, raiz e peso dos nódulos. A adição de 1 a $2 \mathrm{mM}$ de cālcío foi suficiente para prevenir os efeitos prejudiciais da solução salina. Em relatos posteriores, WIGNARAJAH et alii (1975a e 1975b) observaram que a adição de $48 \mathrm{mM}$ de $\mathrm{NaCl}$ ao feijoeiro, comprometeram a dí visão celular, os níveis de carboidratos, e a concentração de glicose, inositol e sacarose.

\section{5 - Efeito do Fósforo}

o fósforo é um dos elementos que o solo armazena temporariamente e transforma, sendo talvez, o elemento que mais frequentemente limita a produção nas regiões tropicais e subtropicais (MALAVOLTA, 1976); nos ecosistemas agrícolas possivel mente em maior extensão do que o cälcio e o potássio (BRAY, 1954). o fósforo tem um papel vital no metabolismo da planta, como cons tituinte de vários compostos importantes, tais como, nucleotídeos, nucleoproteinas, ATP, NAD (nicotinamida-adenina dinucleotídeo), NADP (fosfato de nicotinamida-adenina dinucleotídeo) (LAMBERT e TOUSSAINT, 1977).

Segundo WORTHEN e ALDRICH (1967), as culturas dispões de mais $P$ quando $o$ pH se encontra entre a faixa de 6,0 é 7,0. Quando o $\mathrm{pH} e$ inferior, o fösforo fica retido pelos com- 
postos de Fe e Al, e quando é maior do que 7,0 os fosfatos mono cálcico e dicálcico se transformam em fosfato tricálcico, menos solūvel. Admitiram värios autores (WARNOCK, 1970 ; LOPEZ G. e MALAVOLTA, 1974 ; HAUSENBUILLE, 1975), que doses elevados de $P$ afetam a disponibilidade de zinco, podendo provocar uma "deficiência de $\mathrm{Zn}$ induzida pelo fosfato" nos tecidos da planta.

A adubação fosfatada tem um papel relevante na nodula ção, fixação simbiótica, extração de nitrogênio e teor de $N$ das plantas (ANDREW e ROBINS, 1969 a; JONAS e FREITAS, 1970 ; KOLLING et alii, 1974 e 1976).

Segundo SAITO e RUSCHEL (1976), a aplicação de 150 ppm de $\mathrm{P}_{2} \mathrm{O}_{5}$ aumentou o número e o peso dos nódulos do feijoeiro, quando cultivado em vasos com diferentes tipos de solos. o nível crítico disponível do fósforo para Phaseolus vulgaris, foi estabelecido em solos do Rio Grande do Sul por GOEPFERT (1972), como sendo em torno de 18 ppm. Relataram KOLLING et alii (1974), que a adubação fosfatada foi fator decisivo para uma nodulação eficiente em Phaseolus atropurpureus (Macroptilium atropurpureum, e apresentou efeitos significativos até a maior dose aplicada $\left(360 \mathrm{~kg}\right.$ de $\left.\mathrm{P}_{2} \mathrm{O}_{5} / \mathrm{ha}\right)$.

São escassos os dados registrados na literatura sobre a composição mineral de leguminosas tropicais. ANDREW e ROBINS (1969a) em ensaio de vasos com solos, envolvendo nove leguminosas tropicais, verificaram que a aplicação de $\mathrm{NaH}_{2} \mathrm{PO}_{4} \cdot \mathrm{H}_{2} \mathrm{O}$ em doses de 0,138 a $0,828 \mathrm{~g} / \mathrm{vaso}$, correspondendo a 100 a $1200 \mathrm{Kg} / \mathrm{ha}$ de superfosfato $\operatorname{com} 9,6 \%$ de $P$, permitiu concentrações de $P$ na parte aérea variáveis entre 0,10 e $0,36 \%$. 
Segundo ANDREW e ROBINS (1969b) há uma boa correlação entre $P$ e $N$ na planta, relacionada diretamente com a quantidade de fosfato adicionado ao solo. Este efeito pode ser atribuido ao desenvolvimento do sistema radicular (DUNCAN e OHLROGGE, 1958), eficiência dos nódulos; Jones, 1968 e ao metabolismo da planta (COLE et alii, 1963). Doses crescentes de superfosfato $\operatorname{com} 9,6 \%$ de $\mathrm{P}(100$ a $1200 \mathrm{~kg} / \mathrm{ha})$ elevaram os teores de $\mathrm{N}$ da par te aérea de nove leguminosas forrageiras tropicais, alcançando níveis entre 1,93 e 4,01\% (ANDREW e ROBINS, 1969b). Em ensaio de campo conduzido por COBRA NETO (1967), o autor relatou que - feijoeiro apresentou aos 25 dias de idade, os seguintes teores de N e P: raiz, 2,95 e 0,28\%; caule, 2,90 e 0,22\%; folhas, 4,48 e $0,27 \%$; aos 46 dias, os referidos nutrientes estiveram assim distribuidos: raiz, 1,61 e $0,11 \%$; caule, 1,61 e 0,19\%; folha, 3,36 e $0,35 \%$.

2.6 - Efeito do Alumínio, Ferro, Manganês e Molibdênio

Em elevadas concentrações, o alumínio afeta a planta saturando as células livres do córtex, inibindo o crescimento da raiz, mas não interfere na atividade metabólica do fósforo na parte aérea (RORISON, WALLIHAN, citados por RUSCHEL et alii, 1968). Segundo värios autores (CLARKSON, RORISON, citados por MALAVOLTA, 1976), o Al interfere no funcionamento dos metabólitos fosforilados, inibe a hexoquinase, afeta a produção de DNA e reduz a incorporação de fósforo inorgânico em RNA. A toxidez de Al é comumente considerada (WUTKE, 1975) como o principal e- 
feito pernicioso da acidez, admitindo-se que 1 ppm de Al sóluvel seja tóxico para a maioria das plantas cultiviadas.

Relatou FOY (1974) que há pouca informação sobre o efeito direto do Al sobre o Rhizobium, mas deve-se distinguir entre a ação do alumínio sobre suas células no solo, sobre a forma ção do nódulo e sobre a própria fixação do nitrogênio. Embora e xistam diferenças entre variedades com respeito à tolerância do Al, admitiram KAMPRATH e FOY (1971) que o principal efeito sobre a fixação de $\mathrm{N}_{2}$ está provavelmente relacionado com os danos causados ao crescimento da raiz, redução do número de nódulos e interferência com a absorção e o transporte do cálcio.

Segundo RUSCHEL et alii (1968), o feijoeiro quando cul tivado em solução nutritiva, teve seu desenvolvimento afetado com concentraçôes iguais ou superiores a 3 ppm de Al, enquanto que 7 ppm ou mais efetaram significativamente o teor de Al tanto na raiz, como na parte aérea, situando-se entre 0,95 e 1,60\%, e entre 0,09 e $1,18 \%$, respectivamente.

Relatou FOY et ali $i$ (1967) que as variedades "Dade" e "Romano" de Phaseolus vulgaris reagiram de modo diferente às con centrações de alumỉnio ( 0 a 8 ppm) adicionado à solução nutritiva. Com 8 ppm de Al, a variedade "Romano" alcançou uma produção de raízes e parte aérea correspondente a 59 e $53 \%$, respectivamen te, dos valores obtidos com o nível o (zero), enquanto a varieda de "Dade" não foi afetada, am sua parte aérea, mas as raízes apresentaram uma tendência para um maior crescimento. 
o ferro ocorre nas células das plantas principalmente na forma de porfirinas, atuando como um grupo prostético ou funcional dos citocromos, peroxidases, catalase e leg-hemoglobina. Estā também presente em vārias enzimas importantes, inclusive ferredoxinas, proteinas transferidoras de elétrons (BUTLER e JONES,1973). Análises de plantas cloróticas com elevados teores de ferro, sugerem que o Fe se apresenta sob forma insolúvel, sem participação efetiva nos processos matabólicos.

Segundo MULDER e BROTONEGORO (1974), um suprimento insuficiente de ferro que afete o crescimento das bactérias pode interferir na fixação do nitrogênio, afetando a síntese ou o fun cionamento de uma ou mais enzimas. A presença de elevados teores de Fe na nitrogenase justifica a necessidade da racionalizaça do seu emprego (POSTGATE, 1974).

Relatou MALAVOLTA (1976) que a falta de arejamento pode elevar a concentração de ferro nas raízes, mas a presença de certos fungos, nematoides e outros microrganismos pode afetar a sua absorção. Quanto à ação inibitória do Fe-EDTA sobre a nodulação (LIE, 1974), cujos efeitos assemelham-se à deficiência de cálcio e acidez, afirmaram LIE e BROTONEGORO (1969) que ela só é efetiva quando o quelado está em contacto com a raiz. Ainda segundo os mesmos autores, $0,1 \mathrm{mM}$ de Fe-EDTA ( $5 \mathrm{ppm}$ de Fe), concentração normalmente adicionada à solução nutritiva, inibiu a nodu 1 ação de Pisum sativum L.; $0,2 \mathrm{mM}$ inibiu-a fortemente, ao passo que concentrações mais elevadas $(0,3$ a $0,5 \mathrm{mM})$ provocaram inibição quase total. 
Sabe-se de hã muito, que o manganês deve desempenhar um papel na fotossintese, porquanto a intensidade da mesma diminui quando hā deficiência desse elemento (MAlavolta et alii, 1974). Segundo os referidos autores, hā uma relação entre o Fe e o Mn na nutrição das plantas, sendo conhecido o fato de que um excesso do segundo no meio diminui a concentração do primeiro tecido. Se gundo SOMERS e SHIVE (1942), a explicação teórica desse relacionamento reside no fato de que, metabolicamente, o Fe funciona principalmente no estado reduzido $\left(\mathrm{Fe}^{+2}\right)$ e tem um potencial de o xidação menor do que o manganês. Para um bom crescimento e desenvolvimento da planta admitiram SOMERS e SHIVE (1942) que a re lação Fe/Mn deve se situar entre 1,5 e 2,5 .

As plantas diferem quanto ao grau de tolerância ao excesso de Mn (MORRIS e PIERRE, 1949), sendo o amendoim mais tolerante do que o cowpea a soja, e estes muito mais do que a lespedeza e o trevo doce. Em feijoeiro, relatou Malavolta (1976), ocorrem sintomas de toxidez quando o teor de Mn nas folhas alcan ça 1000 ppm, a ervilha 550 ppm e a cevada 200 ppm. A susceptibi lidade das leguminosas à toxidez de $M n$, além de diferir entre as espécies, também pode depender da variedade estudada (FREIRE e VIDOR, 1971). Diferenças significativas com relação ao número e peso dos nódulos, nitrogênio total, cālcio e manganês nos teci dos, em variedades de soja foram relatadas por vários autores (DOBEREINER e ARRUDA, 1967 ; CABEDA e FREIRE, 1968). Outros pesquisadores (SOUTO e DOBEREINER, 1969) encontraram diferenças sig nificativas para a interação Espēcie $x$ Mn no tecido, com relação ao peso dos nódulos, matéria seca, teor de nitrogênio e nitrogênio total em Centrosema pubescens, Pueraria javanica, Macropti 
lium atropurpureum e Glycine javanica.

Relatou LOHNIS (1951) que o feijoeiro tem uma sensibilidade específica à toxidez de Mn, afetando a fixação simbiótica do nitrogênio. A adição de 40 ppm de Mn (DOBEREINER, 1966) afetou a quantidade de $N$ total e o número de nódulos por planta, mui to embora a extensão dos efeitos tenha variado bastante entre as estirpes de Rhizobium phaseoli utilizadas. No mesmo relato, observou a autora que tanto a nodulação como a fixação de nitrogênio foram menos afetada na soja.

A essencialidade do molibdênio para as plantas superio res foi demonstrada em 1939 por ARNON e STOUT, cultivando o toma teiro em solução nutritiva, quando verificaram também que esse micronutriente deveria estar implicado nometabolismo do nitrogênio (MALAvolta et alii, 1974). Segundo ANDREW (1962) o Mo é essencial na nutrição das leguminosas em suas fases: na fixaça do $N$ pelo Rhizobium no nódulo e na transformação de nitratos em amônia.

Relatou GAUCH (1973) que as exigências das plantas superiores em Mo, são muito reduzidas, quando em presença de $\mathrm{NH}_{4}$, mas não podem ser totalmente abolidas. Plantas deficientes em Mo, acrescentou o autor, acumulam nitrato nas folhas, mas os sin tomas desaparecem com a aplicação do nutriente.

0 Mo é essencial para a fixação simbiótica do nitrogênio, daí porque as deficiências são com mais frequência observadas em leguminosas, mas podem ser corrigidas com aplicaçóes no solo, por 
via foliar, ou através da própria semente. As exigências da soja cultivada em solos deficientes em Mo poderão ser satisfeitas usando-se sementes com altos teores de molibdênio (GURLEY e GIDDENS, 1969). Tais observações estão de acordo com o relato de HEWITT e SMITH (1975), quando afirmaram que as reservas de Mo, $\mathrm{C}_{\zeta_{6}}$ Zn e possivelmente $C 1$, existentes nas sementes das leguminosas, podem se constituir em fatores significativos nos resultados obtidos; feijões (Phaseolus vulgaris) e ervilhas especialmente, pos suem Mo nas sementes em quantidades suficientes para o crescimen to total das plantas e suprimento de deficiências, podendo inclusive persistir por duas gerações. Para o feijoeiro, os autores relataram niveis de 2 a 8 ppm de Mo ( 1 a $5 \mu \mathrm{g} / \mathrm{semente);} 4$ a 10 ppm de $M n(2$ a $5 \mu g / s e m e n t e) ; 3$ a 8 ppm de Cu (1,8 a $4 \mu g / s e m e n t e)$; 26 a $42 \mathrm{ppm}$ de $\mathrm{Zn}(13$ a $20 \mathrm{\mu g} / \mathrm{semente})$ e $160 \mathrm{ppm}$ de Cl (83 $\mathrm{\mu g} / \mathrm{se}$ mente).

Apesar da importância do molibdênio para as leguminosas tropicais, devido à sua adaptação aos solos ácidos, elas são presumivelmente mais eficientes na sua obtenção e utilização (FREI RE e VIDOR, 1971). Em geral, acrescentaram os mesmo autores, o Mo reduz o número de nódulos, mas aumenta o seu tamanho, alteran do-1he a cor e o formato, o que pode ser complicado por outros fatores, tais como o suprimento de fósforo ou de enxofre, que po de reduzir ou anular o efeito depressivo. o feijoeiro parece ter exigências específicas para responder à aplicação de Mo em solos äcidos (FRANCO; 1977). Quando cultivado em solo arenoso 
da série Ecologia, com $\mathrm{pH} 4,5$ foi afetado pela aplicação de 5 kg/ha de molibdato de sódio, tendo diminuido o número de nódulos e aumentado a quantidade de nitrogênio fixado por nódulo (RUSCHEL et alii, 1966). 
32 .

3 - MATERIAL E METOdOS

3.1 - Instalação dos experimentos

os experimentos foram instalados e conduzidos em casa de vegetação localizada no CENA (Centro de Energia Nuclear para a Agricultura), anexo à Escola Superior de Agricultura "Luiz de Queiroz", da Universidade de São Paulo, em Piracicaba, no período compreendido entre abril e novembro de 1977 .

\section{2 - Variedades estudadas}

Foram estudadas três variedades de feijoeiro (Phaseolus vulgaris L.), a saber. Venezuela 350 e Carioca, procedentes da Seç̧ão de Microbiologia do CENA, e Rico 23, procedente do Instituto Agronômico de Campinas. Segundo estudos realizados por AMA- 
RAL (1975), as três variedades foram consideradas como de baixa, alta e média produtividade, respectivamente, em ensaios conduzidos em solução nutritiva.

\section{3 - Estirpes de Rhizobium utilizadas}

Foram utilizadas três estirpes de Rhizobium phaseoli, desenvolvidas em cultura pura, quando da inoculação das sementes do feijoeiro: $127 \mathrm{~K}_{17}$ e $127 \mathrm{~K}_{14}$, ambas da Cia Nitragin (USA), e C $_{13}$, isolada nos laboratórios da Seção de Microbiologia do Solo do CENA. A preparação do inoculante foi feita com o emprego do meio de cultura 79 , de acordo com recomendações de RUSCHEL (1977). A composição do referido meio de cultura é a seguinte:

$$
\begin{aligned}
& \mathrm{K}_{2} \mathrm{HPO}_{4} 0,5 \mathrm{~g} ; \mathrm{MgSO}_{4} \cdot 7 \mathrm{H}_{2} 00,2 \mathrm{~g} ; \mathrm{NaCl} 0,1 \mathrm{~g} ; \mathrm{Glicose}, \\
& \text { dextrose ou Manitol } 10,0 \mathrm{~g} ; \text { Extrato de levedura } 2,0 \mathrm{~g} ; \mathrm{A}- \\
& \text { gar } 12,0 \mathrm{~g} ; \text { Agua destilada } 1.000 \mathrm{ml} ; \mathrm{FeCl}_{3} 10,0 \mathrm{mg} ; \mathrm{CaCO}_{3} \\
& 3,0 \mathrm{~g} .
\end{aligned}
$$

Partes iguais das diferentes estirpes de Rhizobium fo ram empregadas na mistura. 


\section{4 - Plantio}

Inicialmente procedeu-se a um ensaio de germinação com sementes das variedades de feijão a serem estudadas, em papel de filtro e àgua destilada. As variedades Venezuela 350 e Carioca, apresentaram mais baixo poder germinativo (70 a $80 \%)$, enquanto a variedade Rico 23 procedente do IAC alcançou $95 \%$.

Precedendo a inoculação, as sementes foram uniformemen te selecionadas, colocadas em um copo de 100 ml e embebidas em álcool absoluto durante três minutos. Em seguida o copo foi esvaziado, e as sementes foram imersas em hipoclorito de sódio a 10\% durante cinco minutos; decorrido o tempo procedeu-se a uma lavagem com àgua esterilizada.

Tendo como substrato a vermiculita, devidamente esteri lizada em autoclave a 1209C, e utilizando-se bandejas de plástí co que mediam $40 \times 50 \times 8 \mathrm{~cm}$, previamente desinfectadas, foi fei to o plantio em covas rasas, com espaçamento de $5 \mathrm{~cm}$ entre 1 inhas e entre fileiras. O umidecimento da vermiculita foi feito no momento do plantio com a Solução Nutritiva no 1 de HoAGLAND e ARNON (1950), diluida a $1: 5$.

Decorridos 10 (dez) dias apōs o plantio, as mudas foram transplantadas para bandejas de plástico com capacidade para 35 litros, cujas paredes externas haviam sido isoladas com duas camadas de tinta, preta betuminosa e purpurina branca. 
Um sistema de arejamento e controle das condições ambientais (temperatura e luminosidade) foi acionado ininterruptamente. Para isto foi colocado um termômetro de máximas e mínimas para verificação da temperatura da casa de vegetação (Tabela 1) e solução nutritiva, e simultaneamente,alternava-se a posição das bandejas, permitindo uma distribuição mais uniforme da luminosidade durante o fotoperíodo. Procedeu-se também um combate sistemático ao oỉdio Erysiphe polygoni DC ex Merat. através de Karathane WD, na concentração de $0,8 \mathrm{~g} / 1$ itro. Periodicamente fo ram feitas pulverizações com o acaricida AKAR 338 ( 2 ml/1itro).

Toda a solução nutritva foi substituida em todos os ex perimentos, a cada 10 dias de intervalo, ao passo que diariamente, quando necessārio, era adicionada água distilada às bandejas para completar o volume da solução.

\section{5 - Delineamento Experimental}

o delineamento experimental proposto e adotado foi o de parcelas subdivididas (KEMPTHORNE, 1973), cujo esquema de anālise de variância apresentamos a seguir: 
Esquema da Anālise de Variância

\begin{tabular}{|c|c|c|c|c|c|}
\hline \multirow{2}{*}{$\begin{array}{l}\text { Causa de } \\
\text { Variação }\end{array}$} & \multicolumn{5}{|c|}{ Graus de Liberdade } \\
\hline & $\begin{array}{l}19 \text { Ensaio } \\
\text { (N) }\end{array}$ & $\begin{array}{l}29 \text { Ensaio } \\
\text { (PN) }\end{array}$ & $\begin{array}{l}39 \text { Ensaio } \\
\text { (Ca) }\end{array}$ & $\begin{array}{c}40 \text { Ensaio } \\
\text { (P) }\end{array}$ & 50 Ensaio \\
\hline Substratos (S) & 4 & 4 & 7 & 5 & 6 \\
\hline Variedades (V) & 2 & 2 & 2 & 2 & 2 \\
\hline$S \times V$ & 8 & 8 & 24 & 10 & 12 \\
\hline Res. (a) & 45 & 45 & 72 & 54 & 63 \\
\hline Parcelas & (59) & (59) & (95) & (71) & (83) \\
\hline Epocas (E) & 1 & 1 & 1 & 1 & 1 \\
\hline$E \times S$ & 4 & 4 & 7 & 5 & 6 \\
\hline$E \times V$ & 2 & 2 & 2 & 2 & 2 \\
\hline$E \times V \times S$ & 8 & 8 & 14 & 10 & 12 \\
\hline Res. (b) & 45 & 45 & 72 & 54 & 63 \\
\hline Total & 119 & 119 & 191 & 143 & 167 \\
\hline
\end{tabular}


TABELA 1 - Temperaturas médias registradas na casa de vegetação no período de Fev. a Nov. de 1977 (em QC)

\begin{tabular}{lccc}
\hline Meses & $\begin{array}{c}\text { Médias das } \\
\text { Máximas }\end{array}$ & $\begin{array}{c}\text { Médias das } \\
\text { Mínimas }\end{array}$ & $\begin{array}{c}\text { Médias } \\
\text { Mensais }\end{array}$ \\
\hline Fevereiro & 33,1 & 20,2 & 26,6 \\
Março & 31,3 & 19,4 & 25,5 \\
Abril & 26,5 & 15,1 & 20,8 \\
Maio & 25,5 & 11,1 & 18,3 \\
Junho & 24,3 & 11,5 & 17,9 \\
Julho & 28,2 & 10,6 & 19,4 \\
Agosto & 28,7 & 11,4 & 20,0 \\
Setembro & 29,1 & 13,5 & 21,3 \\
Outubro & 30,3 & 15,9 & 23,1 \\
Novembro & 29,9 & 17,3 & 23,6 \\
\hline
\end{tabular}


Dentro do esquema experimental proposto, as variedades estudadas representaram as parcelas, as colheitas representaram as subparcelas, e os substratos ou tratamentos, representaram os blocos. 0 emprego dos diferentes testes para a comparação das mëdias foi feito de acordo com as recomendações de PIMENTEL GoMES (1970) e REMPTHORNE (1973). A transformação dos dados objé tivando uma maior precisão dos resultados, se deu de acordo com os estudos de SNEDECOR e COCHRAN (1974).

3.6 - Colheita e preparo do material

Foram feitas duas colheitas, aos 25 e 45 dias de crescimento vegetativo. Inicialmente separou-se a raiz da parte aérea, quando esta $\bar{l}$ tima depois de colocada em sacos de papel numerados foi levada à secagem em estufa à temperatura de 75-80oc. Manipuladas cuidadosamente, as raízes eram enxugadas em papel ab sorvente e colocadas em frascos de vidro (62 ou 500 ml) paramedição do $N$ fixado atravēs do método de redução do acetileno (HAR DY et alii, 1968 e 1973). 


\section{7 - Determinação da atividade da Nitrogenase}

A atividade da Nitrogenase foi determinada na Seção de Microbiologia do Solo do CENA. Para tanto, a colheita foi feita sempre entre 9 e 12 horas da manhã, quando a atividade é máxi ma (HARDY et ali $i, 1968$ ). Previamente enxuto, o sistema radicular foi colocado nos frascos de vidro, fechados com rolhas de borracha e mantidos sob atmosfera contendo $10 \%$ de acetileno e ar atmosférico. Amostras controles para etileno, como contaminante do acetileno injetado, foram analisadas, e o resultado subtraí do de cada amostra na avaliação da atividade total da $\mathrm{N}_{2}$-ase. os cálculos para os teores de etileno foram feitos tomando-se em consideração diferentes amostras de um mesmo padrão de etileno in jetado no cromatógrafo para cada experimento. Após uma hora de incubação, amostrass de $0,5 \mathrm{ml}$ foram retiradas e analisadas em cromatógrafo de gās Beckman G.C. -65 , com coluna separadora de Pó rapak $N$, sob temperatura de $1109 \mathrm{C}$, usando-se chama de ioniza ção de hidrogênio e gás nitrogênio como transportador de gases. A determinação da Atividade específica da nitrogenase foi feita levando-se em consideração o etileno formado (umoles) e a massa nodular (g de M. S. - Matēria Seca)

3.8 - Determinaçōes analf ticas dos macro e micronutrientes

Depois de determinada a atividade da nitrogenase, as raízes foram lavadas em água destilada, quando os nódulos foram destacados para contagem e determinação do peso da matéria seca 
após secagem em estufa a 75-809C.

As determinações dos macro e micronutrientes dos diferentes segmentos da planta foram feitas na Seção de Química Analítica do CENA, de acordo com as recomendações de BREMNER (1965), e PARKINSON e ALLEN (1975). As leituras foram realizadas no Au toanalyzer II Technicon e no Atomic Absorption spectrophotometer Perkin-Elmer, Modelo 306.

\section{9 - Experimentos realizados}

Experimento 1: Niveis crescentes de $N$

Neste experimento foram estudados os efeitos do $N$ combinado $\left(\mathrm{NO}_{3}^{-}\right)$na nodulação, fixação de nitrogênio e produção de matéria seca, objetivando basicamente a dose "arranque" de $N$ indispensável ao desenvolvimento inicial da planta. Assim sendo, foram estabelecidos cinco tratamentos: a) solução completa ; b) solução sem $N$; c) solução $\operatorname{com} 0,1 \mathrm{~N}$ da completa $(0,3 \mathrm{mM}$ de $\left.\mathrm{N}-\mathrm{NO}_{3}^{-}\right)$; d) solução com $0,2 \mathrm{~N}\left(0,6 \mathrm{mM}\right.$ de $\left.\mathrm{N}-\mathrm{NO}_{3}^{-}\right)$; e) so 1 ução $\operatorname{com} 0,4 \mathrm{~N}\left(1,2 \mathrm{mM}\right.$ de $\left.\mathrm{N}-\mathrm{NO}_{3}^{-}\right)$. A composição total das refé ridas soluções foi feita segundo recomendações de vārios autores (HOAGLAND e ARNON, 1950 ; MALAVOLTA, 1975 ; RUSCHEL, 1977), e es tá inserida na Tabela 2 . 
TABELA 2 - Composição química das soluções nutritivas, diluídas a $1: 5$, utilizadas no ensaio sobre o efeito de niveis crescentes de nitrogênio

\begin{tabular}{|c|c|c|c|c|c|}
\hline \multirow{2}{*}{ Soluções estoque } & \multicolumn{5}{|c|}{ ml / litro de solução } \\
\hline & Completo & $-\mathbf{N}$ & $0,1 \mathrm{~N}$ & $0,2 \mathrm{~N}$ & $0,4 \mathrm{~N}$ \\
\hline $\mathrm{KH}_{2} \mathrm{PO}_{4} \mathrm{M}$ & 0,2 & - & - & - & - \\
\hline $\mathrm{KNO}_{3} \mathrm{M}$ & 1,0 & - & - & - & - \\
\hline $\mathrm{Ca}\left(\mathrm{NO}_{3}\right)_{2} \cdot 4 \mathrm{H}_{2} \mathrm{O} \mathrm{M}$ & 1,0 & - & - & - & - \\
\hline $\mathrm{MgSO}_{4} \cdot 7 \mathrm{H}_{2} \mathrm{O} \mathrm{M}$ & 0,4 & 0,4 & 0,4 & 0,4 & 0,4 \\
\hline $\mathrm{K}_{2} \mathrm{SO}_{4}, 0,5 \mathrm{M}$ & - & 1,0 & 1,0 & 1,0 & 1,0 \\
\hline $\mathrm{Ca}\left(\mathrm{H}_{2} \mathrm{PO}_{4}\right)_{2} \cdot \mathrm{H}_{2} \mathrm{O} 0,05 \mathrm{M}$ & - & 2,0 & 2,0 & 2,0 & 2,0 \\
\hline $\mathrm{CaSO}_{4} 0,01 \mathrm{M}$ & - & 40,0 & 40,0 & 40,0 & 40,0 \\
\hline $\mathrm{NaNO}_{3} \mathrm{M}$ & - & - & 0,3 & 0,6 & 1,2 \\
\hline Solução a (*) & & $g / 1$ & de soluçã & es toque & \\
\hline $\mathrm{H}_{3} \mathrm{BO}_{3}$ & & & 2,86 & & \\
\hline $\mathrm{MnCl}_{2} \cdot 4 \mathrm{H}_{2} \mathrm{O}$ & & & 1,81 & & \\
\hline $\mathrm{ZnSO}_{4} \cdot 7 \mathrm{H}_{2} \mathrm{O}$ & & & 0,22 & & \\
\hline $\mathrm{CuSO}_{4} \cdot 5 \mathrm{H}_{2} \mathrm{O}$ & & & 0,08 & & \\
\hline $\mathrm{H}_{2} \mathrm{MoO}_{4} \cdot \mathrm{H}_{2} \mathrm{O}$ & & & 0,02 & & \\
\hline Solução b (**) & & & & & \\
\hline
\end{tabular}

(*) A Solução (a) foi adicionada à solução nutritiva na proporção de $0,02 \mathrm{ml} / 1$ itro em todos os tratamentos.

(**) A solução (b) foi preparada segundo recomendações de JACOBSON (1951) e MALAVOLTA (1975), e adicionada à solução nutritiva na proporção de $0,2 \mathrm{ml} / 1$ itro em todos os tratamentos. 
Experimento 2: Efeito do $\mathrm{pH}$

No segundo experimento foi estudada através de cinco tratamentos, a influência de diferentes valores de pH na nodulação, fixação de nitrogênio e produção de maÉria seca. No pri meiro tratamento foi empregada a solução $n$ @ 1 de HOAGLAND e AR NON (1950) no seu pH normal, cujos valores variaram de 5,56 a 7,12. Nos demais tratamentos utilizou-se a solução "arranque", determinada através do ensaio de nitrogênio, com seus valores de pH ajustados para 4,$0 ; 5,0 ; 6,0$ e 7,0 , cuja composição foi a seguinte:

\begin{tabular}{|c|c|}
\hline Elementos & $\mathrm{M} 1 / 1$ de solução \\
\hline $\mathrm{K}_{2} \mathrm{SO}_{4} 0,5 \mathrm{M}$ & 1,0 \\
\hline $\mathrm{Mg} \mathrm{sO}_{4} \cdot 7 \mathrm{H}_{2} \mathrm{O} \mathrm{M}$ & 0,4 \\
\hline $\mathrm{Ca}\left(\mathrm{H}_{2} \mathrm{PO}_{4}\right)_{2} \mathrm{H}_{2} \mathrm{O} 0,05 \mathrm{M}$ & 2,0 \\
\hline $\mathrm{CaSO}_{4} 0,01 \mathrm{M}$ & 40,0 \\
\hline $\mathrm{NaNO}_{3} \mathrm{M}$ & 0,3 \\
\hline Solução a & 0,2 \\
\hline $\mathrm{Fe}-\mathrm{EDTA}$ & 0,2 \\
\hline
\end{tabular}

os valores de pH nas faixas correspondentes aos tratamentos $(4,0 ; 5,0 ; 6,0 ; 7,0)$ foram ajustados na solução acima, duas vezes por dia com o emprego de potenciômetro e soluções de HCl $0,1 \mathrm{~N}$ e $\mathrm{NaOH} 0,1 \mathrm{~N}$. 
Experimento 3: Nívels crescentes de Ca e Solução salina

Neste experimento foram estabelecidos oito tratamentos cujas soluções apresentaram a composição da Tabela 3

Como se verifica na Tabela 2 o nitrogênio foi adiciona do à solução como dose "arranque", sob a forma de $\mathrm{NaNO}_{3}$. A quan tidade pré-estabelecida $(0,3 \mathrm{mM})$ decorreu em função da melhor resposta encontrada para os diferentes parâmetros estudados.

Experimento 4: Niveis crescentes de $P$

No presente experimento foram estudados seis tratamentos, cujas soluções nutritivas apresentaram a composição da Tabe 1 a 4 .

Experimento 5: Efeito do Al, Mn, Fe e Mo

Neste ensaio foi empregada a solução nutritiva estudada no ensaio anterior, onde o $N$ esta presente como dose de "arranque" $\left(0,3 \mathrm{mM}\right.$ de $\left.\mathrm{N}-\mathrm{NO}_{3}\right)$. A toxidez do alumínio e do manganês foi estudada em duas concentrações dos referidos elementos. Em dois outros tratamentos foram excluídos o ferro e o molibdênio das respectivas soluções, tendo-se o cuidado de empregar água di ionizada para minimizar a contaminação. A Tabela 5 apresenta a composição química das diferentes soluções utilizadas neste expe rimento. 
44.

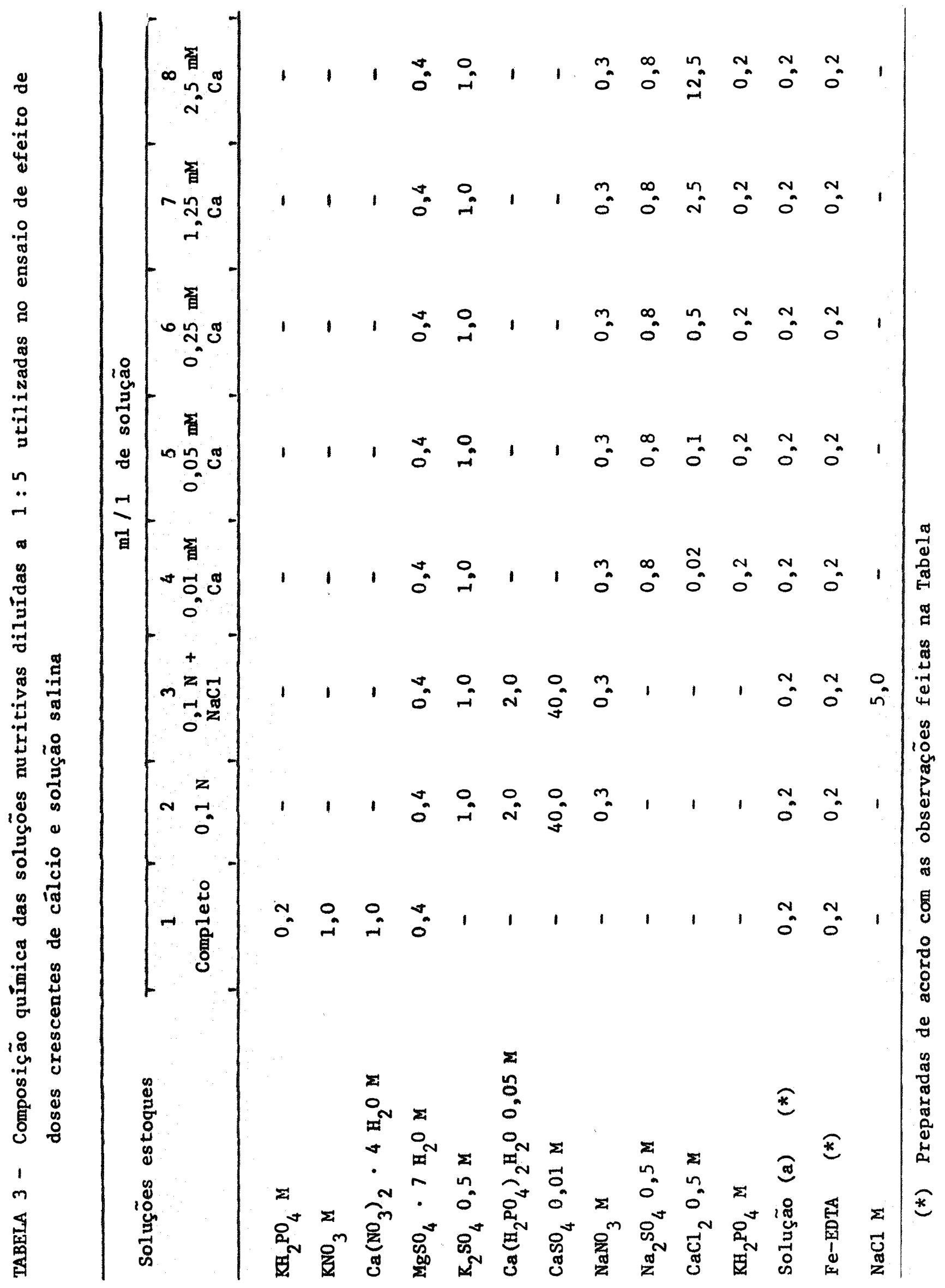




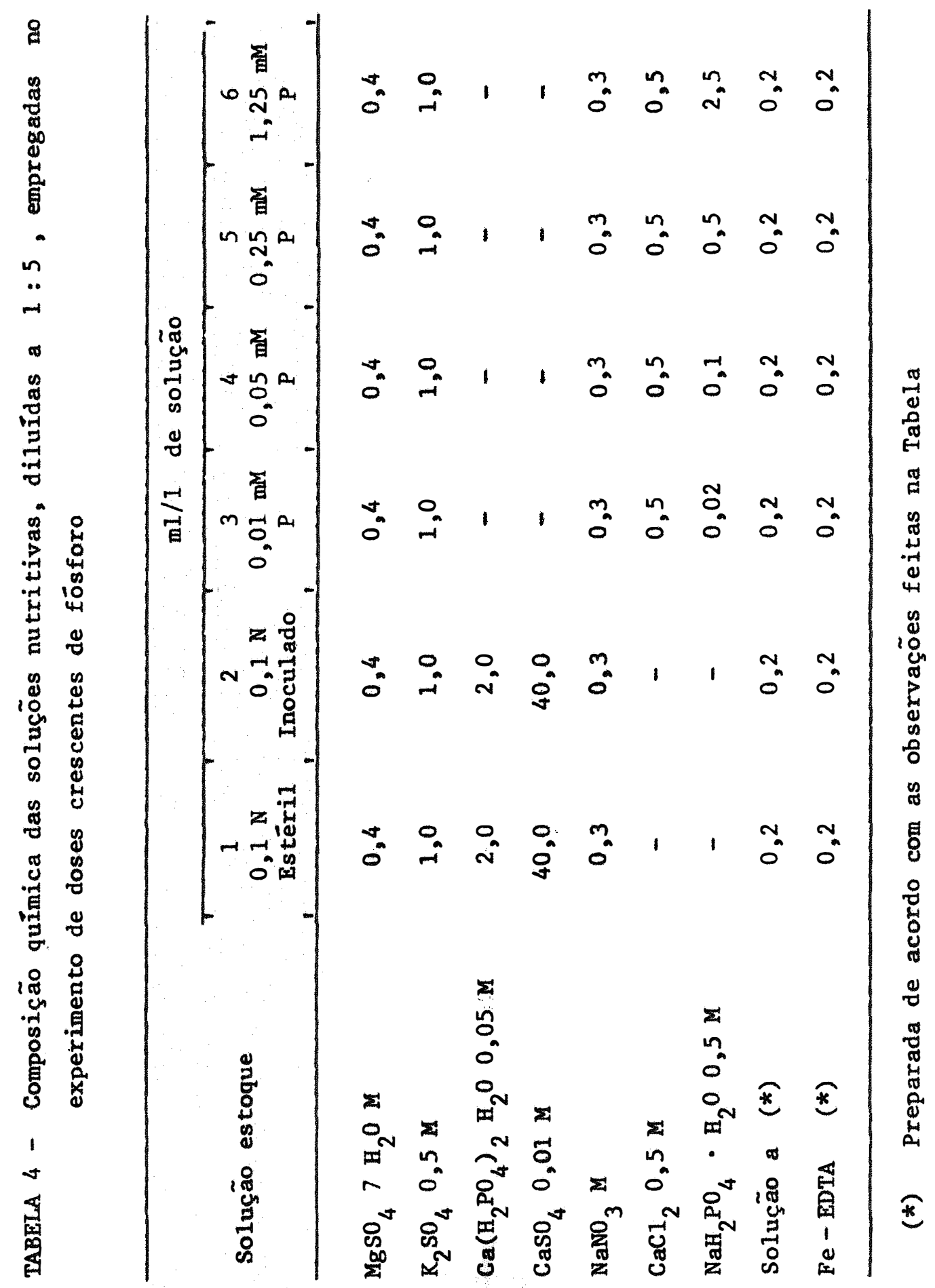




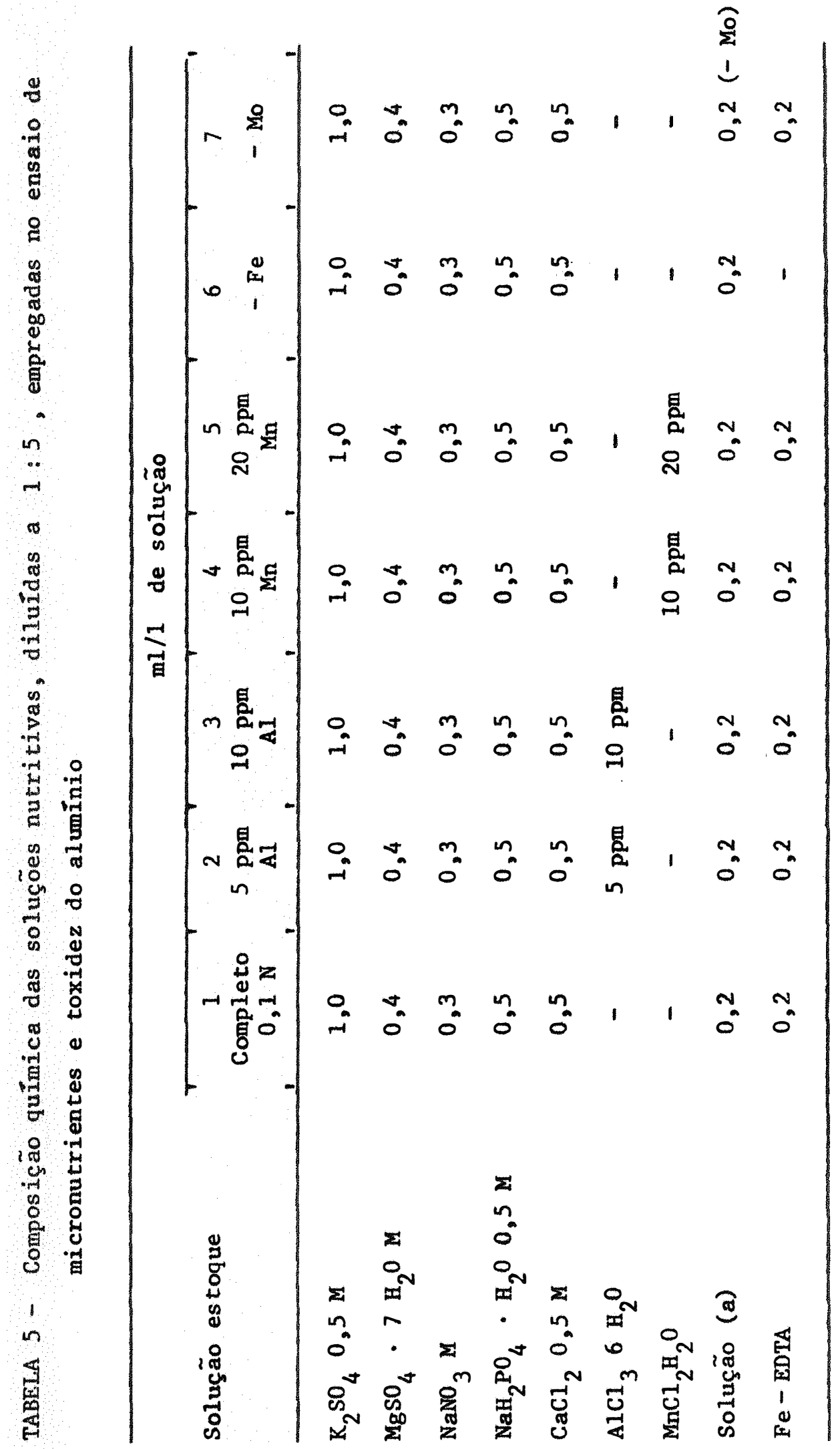


Como se verifica na Tabela 1 , as temperaturas registradas na casa de vegetação durante o transcorrer do período experimental, oscilaram entre 10,6 e 33,1 9C. A média das temperaturas máximas alcançou 28,7 e a das mínimas 14,6 9C. Tais valores se situam nos níveis considerados satisfatórios para as exigências do feijoeiro com relação à temperatura ideal para o seu desenvol vimento (SINGH e MACK, 1966). Por outro lado, as diferenças verificadas entre os valores registrados na casa de vegetação e aqueles da solução nutritiva, que afetariam diretamente o sistema radicular, não comprometeram o desenvolvimento da cultura. Segundo UNGER e DANIELSON (1967), soluções nutritivas submetidas a diferentes temperaturas $(17,5 ; 25,0$ e 32,5 SC), não afetaram a viscosidade e a permeabilidade das raízes do feijoeiro, não comprometendo, por conseguinte, a translocação de produtos da fotos 
síntese da parte aérea para a raiz, nem a fixação de nitrogênio (SOUTO e DOBEREINER, 1970 ; DART et ali $i$, citados por GIBSON, $1976 a)$.

\section{1-Efeito de niveis crescentes de $N$}

Dentro do esquema proposto para a análise de variância dos experimentos, verifica-se que para todas as variáveis estudadas no primeiro ensaio ocorreram diferenças altamente significativas entre Tratamentos ( $T$ ), cujos valores de $F$ são apresentados na $T \underline{a}$ bela 7 .

\subsection{1 - Peso da Materia Seca (M.S.)}

Além das diferenças detectadas entre Tratamentos, a anāli se de variância revelou diferenças altamente significativas para a variāvel Peso da M.S. da parte aérea, entre Variedades (V) e entre Idade de colheita, com valores de F alcançando 5,53 e 661,85, respectivamente.

Os coeficientes de variação (C.V.) revelaram boa precisão do experimento alcançando 20,16 e $20,43 \%$, respectivamente, para os Resíduos (a) e (b).

Para a variável Peso da matéria seca da raiz foi encontra do um valor para $F=3,60$, revelando diferenças significativas en tre Variedades. Também entre Idade de colheita registraram-se 
diferenças altamente significativas, com o valor de F alcançando 518,01. 0s C.V. encontrados também foram baixos, com 22,86\% para o Resíduo (a) e $24,07 \%$ para o Resíduo (b). 0 Peso da M. S. nodular e o Peso da M.S. total também revelaram diferenças altamente significativas entre Idade de corte, com valores de F atin gindo 212,28 e 765,55 respectivamente. Somente a variāvel Peso da M.S. nodular apresentou diferenças altamente significativas en tre Variedades, com o valor de $F=16,63$. Os coeficientes de variação das duas variáveis foram razoāveis (Tabela 7), situan do-se entre 19,21 e $51,35 \%$.

Verifica-se através das Tabelas 6 e 7 , que todas as varie dades de feijoeiro estudadas, Venezuela 350 , Carioca e Rico 23, responderam linearmente às doses de nitrogênio estudadas em ambas as colheitas, tanto para peso da M.S. da parte aérea, como para o peso da M. S. da raiz e M. S. total. Tais resultados confirmaram relatos feitos por diferentes autores (RUSCHEL et ali $i$, 1974 ; KANG, 1975 ; EDJE et alii, 1975).

Com relação ao peso da M.S. nodular (Tabelas 6 e 7) verificou-se aos 25 dias de idade uma relação negativa entre doses de $N$ e peso da M.S. Aos 45 dias de idade, a variedade Venezue1a 350 respondeu 1 inearmente até $0,6 \mathrm{mM}$ de $\mathrm{N}^{-\mathrm{N} 0_{3}^{-}}$para cair bruscamente com $3,0 \mathrm{mM}$ de nitrato. Já as variedades Carioca e Rico 23 mantiveram-se equidistantes entre 0,3 e $1,2 \mathrm{mM}$ de $\mathrm{N}^{-\mathrm{NO}_{3}^{-}} \mathrm{com}$ boa nodulação, para cair verticalmente até os $3,0 \mathrm{mM}$. 0s resul tados obtidos confirmam os relatos feitos por vārios autores sobre doses de "arranque" e sua importância na nodulação (GIBSON, 1974 ; GIBSON, 1976 ; GIBSON e PAGAN, 1977). Segundo MUNNS (1968.a) 0,2 ou $0,5 \mathrm{mM}$ de nitrato reduzem drasticamente o nüme- 
ro de nódulos na primeira colheita, mas nas colheitas subsequentes a redução é diminuta. Doses mais elevadas, alcançando 4,0 mM de $\mathrm{N}^{-\mathrm{NO}_{3}^{-}}$, poderão inibir completamente a nodulação (LONERAGAN, 1972 ).

A dupla ação de $N$ combinado justifica plenamente os resul tados obtidos; doses baixas são necessārias para estimular o crescimento inicial, já que plantas jovens exigem um suprimento elevado de carboidratos para atender à demanda das folhas, raízes e nódulos. Doses muito elevadas inibem a formação de filamento de infeção e interferem na produção e atividade do AIA in dispensável à própria infecção.

\section{1 .2 - Nitrogênio absorvido}

A anālise de variância revelou diferenças significativas entre Tratamentos, como se verifica nos valores de Finseridos na Tabela 7, para a porcentagem de $N$ da parte aérea. Por outro $1 a-$ do, ocorreram diferenças altamente significativas entre Idade de cortes, cujo valor de F alcançou 89,62. Os coeficientes de variação foram baixos e atingiram 21,17 e $13,91 \%$ para os dois resí duos. Os níveis de $N$ encontrados se situaram entre 1,42 e 4,00\% aos 25 dias, e entre 1,41 e 2,39 aos 45 dias de idade, corroborando resultados obtidos por värios autores (SISTACHS, 1970 ; AMARAL, 1975).

Com relação à raiz, a anālise estatística revelou diferen ças altamente significativas entre Tratamentos e entre Idade de cortes, cujos valores de F alcançaram 107,73 e 72,24. o ensaio 
revelou boa precisão, com C.V. atingindo 18,29 e $10,65 \%$. Os pe centuais de $\mathrm{N}$ estiveram dentro dos limites encontrados por outros autores (HAAG et alii, 1967 ; AMARAL, 1975), oscilando entre 1,67 e $3,04 \%$ aos 25 dias e entre 1,41 e $2,15 \%$ aos 45 dias.

A anālise de variância revelou diferenças altamente signi ficativas entre Tratamentos para as variáveis \% $N$ total e mg de N/planta (Tabela 7). Diferenças altamente significativas também ocorreram entre Idade de colheita, tanto para porcentagem de

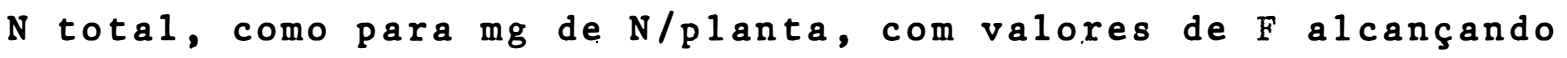
113,81 e 229,27. Os coeficientes de variação para as duas variá veis foram muito baixos, e se situaram entre 8,13 e $18,60 \%$ (Tabe 1a 7). A quantidade de $N$ total absorvido alcançou os níveis obtidos por vários autores(DOBEREINER et ali $i, 1966$; RUSCHEL e RU CHEL, 1975; RUSCHEL e SAITO, 1977) situando-se entre 5,52 e 48,45 mg/planta aos 25 dias, e entre 6,44 e $98,14 \mathrm{mg} / \mathrm{planta}$ aos 45 dias (Tabelas 1 e 2 do Apêndice); tais valores transformados $(\log \times 1,00)$ alcançaram 0,73 a 1,68 e 0,79 e 1,98 , como se veri fica nas Tabelas 6 e 7 .

A quantidade de $\mathbf{N}$ absorvido estā diretamente relacionada com o nivel de $N$ aplicado e potencial de crescimento da planta; além do mais, deve ser considerado o efeito sinérgico do $N$, dai a amplitude dos valores encontrados no experimento. 


\section{1 .3 - Nodulação}

Verifica-se nas Tabelas 6 e 7, que a anālise de variância revelou diferenças altamente significativas entre Tratamentos, pa ra as variáveis número de nódulos e peso médio dos nódulos. Tam bém ocorreram diferenças altamente significativas entre Variedades e entre Idade de colheita para o número de nódulos, cujos va lores de $F$ alcançaram 26,52 e 57,72. Os coeficientes de variação revelaram boa precisão do experimento e alcançaram 28,19 e $25,75 \%$. os resultados obtidos em relação ao número de nódulos nas duas idades de colheita, confirmam relatos feitos por outros autores, com valores médios entre 9 e 209 nódulos/planta, conforme se verifica nas Tabelas 1 e 2 do Apêndice (CARTWRIGHT e SNOW, 1962; GRAHAM e HALLIDAY, 1976 ; RUSCHEL e SAITO, 1977). Segundo FRAN CO e DOBEREINER (1968), doses baixas de N aumentam o número de nódulos mas diminuem o seu peso médio.

Para a variável peso médio dos nódulos os valores de F encontrados revelaram diferenças altamente significativas entre Tratamentos (Tabelas 6 e 7). Também ocorreram diferenças altamente significativas entre Variedades e entre Idade de colheita, e os valores de F alcançaram 9,80 e 48,71 respectivamente. Os coeficientes de variação podem ser considerados satisfatórios, embora altos, dado à natureza do experimento: 47,57 e 50,24\%.

o peso médio dos nódulos para os níveis crescentes de $N$ estudados, alcançou os valores médios de 0,08 a $1,91 \mathrm{mg}$ de matéria seca nodular, situando-se dentro dos limites obtidos por outros pesquisadores (MASEFIELD, 1971 ; RUSCHEL e RUSCHEL, 1975). 
Os nódulos exigem na sua formação certo nível de compostos nitrogenados, daí porque, quando as condições de crescimento são favorāveis à planta, o desenvolvimento dos nódulos pode ser retardado ou inibido sob baixas doses de $N$ combinado.

4.1.4 - Atividade da Nitrogenase $\left(\mathrm{N}_{2}\right.$-ase $)$

Observa-se na Tabela 7 , que a atividade total da $\mathrm{N}_{2}$-ase expressa em $\mu$ moles de etileno $\left(\mathrm{C}_{2} \mathrm{H}_{4}\right)$ apresentou diferenças altamente significativas entre Tratamentos. A anālise de variância também revelou diferenças altamente significativas entre Variedades, Idade de colheita e interação Tratamentos x Variedades, com valores de F correspondentes a 9,$88 ; 37,28$ e 4,10. Os coeficientes de variação foram elevados $(88,72$ e $78,71 \%)$, mas já eram esperados em se tratando de atividade biológica sujeita a va riações bruscas e incontroláveis.

Os níveis de $\mathrm{C}_{2} \mathrm{H}_{4}$ produzido/planta/hora situaram-se com seus valores médios entre 0,002 e 1,04 umoles aos 25 dias de ida de e entre 0,013 e $30,35 \mu m o l e s$ aos 45 dias de crescimento vegetativo (Tabelas 1 e 2 do Apêndice). Tais quantidades confirmam resultados $j \bar{a}$ registrados na literatura por diferentes autores conduzindo ensaios com o feijoeiro (HALLIDAY, 1976 ; GRAHAM e HALLIDAY, 1976 ; RUSCHEL e SAITO, 1977).

A atividade especifica da $\mathrm{N}_{2}$-ase, expressa em $\mu$ moles de etileno/grama de M.S. nodular revelou diferenças altamente signi ficativas entre Tratamentos com valores de $F$ maiores do que os 
da Tabela 7. Verifica-se na mesma Tabela 7, que os coeficientes de variação foram razoāveis, alcançando 37,24 e 40,80\%. A anāli se de variância também apresentou diferenças altamente significa tivas para Variedades e para a interação Tratamentos X Variedades, cujos valores de F alcançaram 11,84 e 4,02. Ainda de acordo com a anāilse de variância, houve diferença significativa entre Idade de colheita, com um valor para F alcançando 4,73.

Os dados sobre nitrogênio fixado avaliados através da atị vidade específica da $N_{2}$-ase, alcançaram valores médios de 2,12 a $92,17 \mu$ moles de etileno/g de M.S. nodular/hora na 1 a colheita

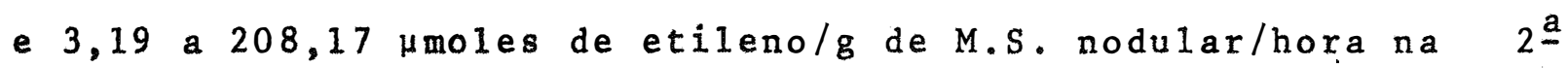
colheita efetuada aos 45 dias de idade. Vários autores em ensaios conduzidos também com ofeijoeiro, obtiveram valores bem aproximados. RUSCHEL e SAITO (1977) relataram 1,85 a $5,99 \mu$ moles de etileno/g de nödulos frescos aos 35 dias de idade, e 12,41 a 29,01 aos 50 dias. HALLIDAY (1976) em um ensaio envolvendo 14 cultivares de Phaseolus vulgaris obtiveram 218 a 324 umoles de etileno/g de M.S. nodular/hora, enquanto GRAHAM e HALLIDAY (1976) relataram niveis que se situaram entre 130 e $250 \mu$ moles de $\mathrm{C}_{2} \mathrm{H}_{4} / \mathrm{g}$ de Matéria seca nodular/hora.

A atividade da nitrogenase foi inibida sob altas doses de $\mathrm{N}$ combinada. Tais resultados sugerem uma provável competição pe los carboidratos entre os nódulos e a parte aērea da planta, resultando na diminuição do número de nódulos e do seu peso médio. A atividade da nitrogenase regulada pelo nível de ATP (BRILL, 1977), e quando o suprimento de ATP é isolado, sem a presença 
de $\mathrm{N}$, a evolução de $\mathrm{H}_{2}$ se processa. Aparentemente, segundo BRILL (1977), o transporte de elētrons se processa normalmente na ausência de $\mathrm{N}$; quando eles alcançam o sítio ativo da enzima, recombinam-se com os prótons.

\section{1 .5 - Correlações}

Verifica-se atravēs da Tabela 16 o grande nümero de correlações encontradas no ensaio sobre o efeito de níveis crescentes de nitrogênio, nas duas idades de colheita. Observa-sena Tabela 16 , que aos 45 dias de idade houve correlação positiva sig nificativa entre M.S. total $x \mathrm{~N}$ absorvido (mg de N/planta), enquanto que aos 25 dias somente as variedades Venezuela 350 e Rico 23 apresentaram tal correlação. As Atividades total e específica da $\mathrm{N}_{2}$-ase do feijoeiro colhido aos 45 dias de idade apresentaram também correlação positiva e significativa nas três variedades estudadas (Tabela 16).

As variáveis M.S. nodular e $N$ absorvido, como mg de $N /$ planta - expresso em $\log (x+1,00)$ apresentaram correlação po sitiva e significativa nas variedades Carioca e Venezuela 350 co 1hidas aos 25 dias de crescimento vegetativo.

Algumas das correlações encontradas e apresentadas na Tabela 16 foram estudadas e relatadas por outros autores. DOBEREINER et alii (1966) relataram que o logarítmo do N total aumen ta 1 inearmente com o peso dos nódulos, após estudos efetuados com soja e feijão. Idêntico resultado foi obtido no cerrado com leguminosas tropicais (FRANÇA e CARVALHO, 1970). 
A correlação positiva e significativa encontrada no presente trabalho (Tabela 16) entre nümero de nódulos e Atividade específica da $\mathrm{N}_{2}$-ase, para a variedade Venezuela 350 aos 25 dias de idade, foi relatada por RUSGHEL e REUSZER (1973). Os autores encontraram correlação positiva nas plantas jovens enegativas nas plantas mais velhas e concluiram afirmando, que, provavelmente, nódulos das plantas jovens tenham tido maior atividade expressa por unidade ou nódulo área do que os nódulos das plantas mais ve 1has. Esta hipótese não tem apoio nos resultados obtidos no pre sente trabalho, uma vez que as variáveis M.S. nodular x Atividade específica da $\mathrm{N}_{2}$-ase apresentaram correlação positiva e signi ficativa para a variedade Rico 23 , tanto aos 25 dias como aos 45 dias de crescimento vegetativo. A variedade Venezuela 350 apresentou idêntica correlação somente com 45 dias de idade.

Em outro relato dos mesmos autores (RUSCHEL e REUSZER, 1973a) foi observada correlação positiva entre \% de $N$ na parte aérea $x$ Atividade específica da $\mathrm{N}_{2}$-ase; entre $\mathrm{N}$ total $x$ Atividade específica, e entre o peso dos nódulos (peso vivo) e atividade específica da $\mathrm{N}_{2}$-ase.

Segundo WHITEMAN (1970), as leguminosas forrageiras trop cais Desmodium uncinatum e Phaseolus atropurpureum (M. atropux pureum apresentaram correlação positiva significativa entre M.S. nodular e M.S. da parte aérea. 
4.2 - Efeito do $\mathrm{pH}$

\subsection{1 - Peso da matéria seca}

Consoante os resultados obtidos através da análise de va riância, registraram-se diferenças significativas entre Tratamen tos (T), conforme se verifica nas Tabelas 8 e 9 , para as variáveis Peso da M.S. da parte aérea, Peso da M.S. da raiz, Peso da M.S. nodular e Peso da M.S. total. Por outro lado, também ocor reram diferenças altamente significativas entre Idade da colheita pa ra as referidas variáveis, cujos valores de F alcançaram, respec tivamente, 350,$11 ; 280,41 ; 530,08$ e 110,21 , sendo amplamente superiores aos valores encontrados na Tabela. Diferenças signi ficativas também ocorreram entre Variedades (V) tanto para o peso da M.S. nodular como para o peso da M.S. total, cujos valores de F atingiram 3,08 e 3,12. Os coeficientes de variação demons traram boa precisão do experimento situando-se entre $22,28 \%$ e $59,35 \%($ Tabela 8$)$.

As diferenças verificadas entre variedades, segundo vários autores, são comuns no gênero Phaseolus (HALLIDAY, 1976; GRA HAM e HALLIDAY, 1976). Verifica-se através das Tabelas 8 e 9 , que o peso total da M.S. elevou-se como aumento do pH. ANDREW (1976) e ANDREW e JOHNSON (1976) também verificaram em leguminosas forrageiras tropicais e temperadas idêntico resultado. Segundo relato de ANDREW (1976) a M.S. de Macroptizium Zathyroides foi máxima no $\mathrm{pH} 4,5$ e em valores mais altos, mas decresceu em 70\% quando o pH caíu para 4,0; em Desmodium uncinatum a produção de M.S. aumentou progressivamente de $10 \%$ em $\mathrm{pH} 4,0$ para $100 \%$ em 
pH 6,0. Segundo ODU et ali $i$ (1971) as leguminosas Centrosema pu bescens e Stylosanthes gracilis alcançaram maior produção de matéria seca (M.S.) nos valores de $\mathrm{pH}$ entre 6,1 e 6,4 ; e entre 5,7 e 6,0 respectivamente. ANDREW e NORRIS (1961) também obtiveram idêntico resultado com as leguminosas Centrosema pubescens Bent. e Stylosanthes bojeri Vog.

Maiores produções de M.S. em leguminosas mantidas nos valores de $\mathrm{pH}$ entre 6,0 e 7,0 foram obtidas por outros autores (MUNNS et alii, 1977). Como a hipótese da influência do Al e Mn estā afastada no presente trabalho, admite-se, que a ação do $\mathrm{pH}$ tenha ocorrido isoladamente, afetando a absorção de outros nu trientes essenciais, ou através de forte interação com o Ca (efeito do íon $\mathrm{H}^{+}$reduzindo a absorção do $\mathrm{Ca}$ ), elemento muito importante para a eficiência da simbiose e o próprio crescimento da planta.

\subsection{2 - Nitrogênio absorvido}

Conforme se verifica nas Tabelas 8 e 9 , ocorreram diferen ças altamente significativas entre Tratamentos para as variáveis \% $N$ da parte aérea, \% $N$ da raiz, \% N total e mg de N/planta. Diferenças também altamente significativas, registradas através da anālise de variância, ocorreram entre Idade da colheita, cujos valores de F alcançaram para as variáveis acima citadas, 220,12; 314,$08 ; 171,17$ e 661,24 . Por outro lado, todos os Coeficientes de variação encontrados foram muito baixos, o que revela boa pre cisão do experimento. Verifica-se na Tabela 8 que seus valores se situaram entre $4,72 \%$ e $10,10 \%$. 
Em que pese as diferenças detectadas entre Tratamentos, não se verificou uma tendência para um aumento do teor de $N$ da parte aérea correspondente à elevação do pH, observada por ANDREW e JOHNSON (1976). Através das Tabelas 8 e 9 , verifica-se que a porcentagem de $\mathbf{N}$ da parte aérea variou de 2,34 a 4,95\%, enquanto que na raiz esses valores se situaram entre 1,65 e $4,94 \%$. ANDREW e JOHNSON (1976) em seu estudo envolvendo várias legumino sas tropicais, encontraram 2,62 a $5,03 \%$ para o $N$ da parte aérea e 1,26 a $4,83 \%$ para as raizes. Estudos conduzidos por MUNN et alii (1977) revelaram em Phaseolus vulgaris que a elevação do pH de 6,0 para 7,0 contribuiu para melhorar as características dos nódulos, mas reduziu a porcentagem de $N$ das folhas de $5 \%$ para $4 \%$. Observando-se a quantidade total de $\mathbf{N}$ absorvido, expressa em mg N/planta (Tabelas 3 e 4 do Apêndice), verifica-se que somente a variedade Venezuela 350 respondeu linearmente aos valores crescentes do $\mathrm{pH}$, apresentando 17,$54 ; 20,05 ; 24,25$ e 25,70 mg de N/planta aos 25 dias de idade e 56,$89 ; 60,63 ; 67,04$ e $71,39 \mathrm{mg}$ de $\mathrm{N} / \mathrm{p} 1 \mathrm{anta}$ aos $45 \mathrm{dias}$ de crescimento vegetativo. Tais resultados estão de acordo com o peso total da M.S. que também apresentou linearidade em Venezuela 350 , nas duas colheitas.

Quando leguminosas são mantidas sob baixos valores de $\mathrm{pH}$, mas na presença de $\mathrm{N}$ combinado, os efeitos do $\mathrm{pH}$, ou da interação $\mathrm{pH} \times \mathrm{Ca}$, são bem menores e não comprometem a quantidade de $N$ absorvido pelas plantas.. Admitem, todavia, alguns autores (ODU et alii, 1971 ; ANDREW, 1977) que tal comportamento pode variar de intensidade, entre espécies ou cultivares. 


\section{$4 \cdot 2 \cdot 3-$ Nodulação}

A anālise de variância revelou diferenças altamente signi ficativas para as variáveis número de nódulos e peso médio dos nódulos, quando influenciadas por valores crescentes de pH (Tabe las 8 e 9). Ocorreram diferenças também altamente signifi cativas entre Idade de Cortes, cujos valores de F alcançaram 220,41 e 472,69 para as duas variáveis, e apenas significativas, isto é, ao nível de $5 \%$ de probabilidade, entre variedades, cujos valores de $\mathrm{F}$ foram 3,58 e 3,61 respectivamente. Os coeficentes de variação foram elevados, porém aceitáveis: 31,08 e 33,88\% para número de nódulos e 65,31 e 63,59\% para peso médio dos nódulos. A variedade Venezuela 350 , embora mantendo a linearidade para a elevação do $\mathrm{pH}$, apresentou nodulação bastante inferior às variedades Carioca e Rico-23, cujas produções foram bastante aproximadas. Com efeito, verifica-se na Tabela 8 , que o número de nódulos expresso em $\sqrt{x+1}$ alcançado pela variedade Carioca para. cada faixa de $\mathrm{pH}$ foi, respectivamente, 3,$41 ; 5,85 ; 5,72$ e 7,03; a variedade Rico-23 apresentou: 3,$56 ; 5,41 ; 5,43$ e 6,84 ; a variedade Venezuela $350,3,26 ; 3,80 ; 3,90$ e 4,24. Na colheita posterior, aos 45 dias de idade, verificou-se igual com portamento com relação à nodulação, isto é, menor número de nódú los para a Venezuela 350 e valores bem superiores para as outras duas. Em números absolutos (Tabela 4 do Apêndice) os valores mé dios alcançados foram: $36 ; 67 ; 65$ e 45 para a var. Venezuela; 43,5 ; 102 ; 99 e 101 para a var. Carioca e 79 ; 118 ; 158,5 e 129 para a var. Rico-23, respectivamente para os valores de pH, 4,$0 ; 5,0 ; 6,0 ; 7,0$. Resposta linear ao $\mathrm{pH}$ foi encontrada ape nas para o Carioca, enquanto que as variedades Venezuela, e Rico 23 decresceram a nodulação com a elevação do pH de 6,0 para 7,0. 
0s resultados obtidos no presente trabalho já eram espera dos, conforme registros encontrados na literatura. Segundo ANDREW (1976) a nodulação de Desmodium uncinatum (leguminosa for rageria tropical) foi severamente reduzida, alcançando apenas $30 \%$ em $\mathrm{pH} 4,0$ e só ligeiramente reduzida no $\mathrm{pH}^{4,5}$, com Medicago sativa cv. Hunter River Broadleaf, classificada em dois grupos, tro pical de verão e temperada de inverno, praticamente não apresentou nodulação nos valores de $\mathrm{pH} 4,0$ e 4,5, exigindo o $\mathrm{pH} 6,0$ para alcançar $100 \%$ de nodulação. Há uma variação muito ampla com relação à tolerância à acidez do solo, entre espécies e estirpes de bactērias nodulares (LONERAGAN, 1972). Segundo o mesmo autor, em valores de $\mathrm{pH}$ muito baixo, o efeito da acidez sobre o crescimento da bactéria do nódulo não é importante em algumas leguminosas. Segundo dados apresentados por ANDREW (1977) M. I $_{\underline{a}}$ thyroides e L. bainesii nodularam bem em toda a faixa de pH compreendida entre 4,0 e 6,0. Acrescentou o referido autor, que em solos férteis contendo significativas quantidades de $N$ disponível, a resposta das leguminosas ao $\mathrm{pH}$ pode ser modificada, mas o efeito simbiótico é importante no funcionamento do sistema.

Com relação ao peso médio dos nódulos, merece registro o fato verificado em $\mathrm{pH} 4,0$ quando todas as três variedades apresentaram um peso médio superior aqueles alcançados nos valores de pH mais elevados, aos 45 dias de crescimento vegetativo. Não foi encontrada resposta justificativa para o fato, principalmente se considerarmos que aos 25 dias de idade o peso era bem menor. Os resultados refletem a existência de nódulos maiores e mais pesados, mas não eficientes na fixação do nitrogênio, cujo desenvolvimento passou a se processar a partir do 250 dia de idade. 
Em geral existe uma correlação positiva e direta entre pro dução de M.S. e nodulação, o que explica a tendência verificada nos resultados aqui obtidos, quando a nodulação apresentou valores mais elevados na faixa de pH entre 6,0 e 7,0.

\subsection{4 - Atividade da Nitrogenase $\left(N_{2}\right.$-ase)}

A anālise de variância revelou para as variāveis Atividade total e Atividade específica da $\mathrm{N}_{2}$-ase, diferenças altamente significativas entre tratamentos, cujos valores de F alcançaram, respectivamente, 16,97 e 14,34 (Tabela 8). Por outro lado, ainda de acordo com a anālise de variância, tambēm ocorreram diferenças altamente significativas entre Variedades e Idade da co1heita, para a Atividade total da $\mathrm{N}_{2}$-ase, com valores de $\mathrm{F}$ atingindo 6,93 e 131,33 respectivamente. Para a Atividade específica da $\mathrm{N}_{2}$-ase não se obteve diferenças significativas nem para Va riedades, nem para Idade da colheita. Os coeficientes de variação foram elevados para a Atividade total da $\mathrm{N}_{2}$-ase $(78,28$ e $79,13 \%)$ e baixos para a Atividade específica $(25,14$ e 27,47\%).

Verifica-se atravēs das Tabelas 8 e 9 , que o comportamento das variedades estudadas diferiu bastante entre os 25 e 45 dias de crescimento vegetativo. Aos 25 dias houve resposta 1 inear aos valores de $\mathrm{pH}$, para a Atividade total da $\mathrm{N}_{2}$-ase, enquan to que aos 45 dias a linearidade desenvolveu-se apenas até o pH 6,0 caindo bruscamente quando o $\mathrm{pH}$ elevou-se para 7,0. A atividade específica da $\mathrm{N}_{2}$-ase, muito embora em grau menos acentuado, a- 
companhou também essa tendência. Os dados não surpreendem uma vez que o número de nódulos apresentou igual tendência, o que re flete uma correspondência entre nodulação e fixação de nitrogênio, em função da elevação do pH.

os resultados obtidos confirmam alguns relatos feitos por outros autores trabalhando com leguminosas tropicais. Na Nigéria, oDU et alii (1971) estudaram o comportamento de Centrosema pubescens e Stylosanthes gracilis em valores de pH que variaram de 5,7 a 8,0 e verificaram que a fixação de nitrogênio foi máxima no pH 6,0. No Brasil, LAERA et alii (1977) relataram que vārios cultivares de Phaseolus vulgaris vegetando em solo äcido não responderam à aplicação de sulfato de cálcio nem de molibdênio, no que concerne à fixação de $N_{;}$somente com a elevação do pH para valores acima de 5,8 é que o crescimento e a fixação de N se processaram.

A quantidade de $\mathrm{N}$ fixado estä diretamente relacionada com a massa nodular e a eficiência desses nódulos. Baixos níveis de fixação alcançados em baixos valores de $\mathrm{pH}$, decorrem naturalmente, de grau de tolerância de feijoeiro à acidez. Várias hipóteses entretanto, tentam explicar o papel isolado de pH na infecção dos pelos radiculares,e que contribui para tornar bastante complexo o problema e exige estudos isolados dos fatores. 


\section{2 .5 - Correlaçọes}

A Tabela 17 apresenta todas as correlações estudadas no ensaio de cālcio, que apresentaram valores de "r" significativos em uma ou outra época de colheita. Verifica-se através da referida Tabela, que as variedades Carioca e Rico 23 apresentaram nas duas colheitas correlação positiva significativa entre Número de nódulos $x$ Atividade total da nitrogenase, e apenas na $2 \stackrel{a}{\text {. }}$ colheita, aos 45 dias de idade, as mesmas variedades apresentaram correlação positiva e significativa entre Número de nódulos e Atividade especifica de $\mathrm{N}_{2}$-ase.

A variedade Venezuela 350 foi a única a apresentar correlação significativa nas duas colheitas, entre M.s. total x pH. A variedade Carioca apresentou correlação significativa entre Núme ro de nódulos $x \mathrm{pH}$, aos 45 dias de crescimento, enquanto a Venezuela 350 teve idêntica correlação aos 25 dias de idade (Tabela 17).

Vários autores vem estudando os efeitos do $\mathrm{pH}$ sobreocres cimento, a nodulação e a fixação de nitrogênio pelas leguminosas. WHITEMAN (1970) encontrou para D. uncinatum e M. atropurpureum, correlação positiva entre número de nódulos e M.s. total. Outros autores também relataram correlação positiva entre M.s. total e $\mathrm{pH}$ em diferentes leguminosas forrageiras tropicais (ANDREW, 1976; ANDREW e JOHNSON, 1976 ; ANDREW, 1977). Os mesmos autores relataram correlações entre\% de plantas noduladas e pH (valores cor respondentes a 4,$0 ; 4,5 ; 5,0$ e 6,0). RICE et alii (1977) de- 
senvolvendo estudos em Medicago sativa L. e Trifolium pratense L. relataram que a produção relativa e a nodulação da alfafa respon deram linearmente à elevação do pH até o valor 6,0; a partir daí manteve-se inalterável com a elevação do $\mathrm{pH}$ ao valor 7,5 .

\section{3 - Efeito do Cálcio e Solução salina}

$$
\text { 4.3.1 - Peso da matëria seca (M.S.) }
$$

Consoante os valores de F encontrados, registraram-se diferenças altamente significativas entre Tratamentos para as va riáveis peso da matéria seca da parte aérea, peso da matéria seca da raiz, peso da matéria seca nodular e peso total da matéria seca. A anālise de variância revelou ainda, para todas as variáveis, diferenças também altamente significativas entre Idade de corte, cujos valores de F alcançaram, respectivamente, 433,31; 592,$90 ; 762,35$ e 572,22. Ocorreram também diferenças entre Va riedades, para as variáveis peso da M.S. da raiz ( $1 \%$ ), peso da M.S. nodular (5\%) e peso da M.S. total (1\%), tendo sido encontra dos valores de F da seguinte ordem: 21,$45 ; 3,28$ e 5,36.

Através das Tabelas 10 e 11 , pode-se verificar que os coe ficientes de variação foram razoāveis e se situaram entre 34,90 e $46,30 \%$. o peso da M.S. da raiz e da parte aérea reagiu quase linearmente, nas duas idades de colheita, até à dose de $1,25 \mathrm{mM}$ de Ca, caindo bruscamente com a dose mais elevada, que correspon deu a $2,5 \mathrm{mM} \mathrm{Ca}$. Comparando-se as médias alcançadas no tratamen to $0,5 \mathrm{mM} \mathrm{Ca}$ com aquelas obtidas no tratamento $0,5 \mathrm{mM} \mathrm{Ca}+\mathrm{NaCl}$, 
verifica-se que todas as variāveis, com exceção de M.S. nodular do feijoeiro aos 25 dias de idade, foram altamente beneficiadas com a adição de solução salina (NaCl).

Vários autores têm admitido a importância da solução sali na no crescimento e nodulação das leguminosas. Segundo MALAVolTA (1976), o sódio é geralmente o constituinte principal dos solos salinos, e como tal, tem efeito adverso no crescimento de muitas espécies vegetais, enquanto o cloro participa da operação do fotosistema II da fotossintese. Esta afirmação sobre a impor tância do $\mathrm{Cl}^{-}$foi contestada por TERRY (1977), isolando cloroplas tos da beterraba açucareira. Segundo BALASUBRAMANIAN e SINHA (1976) em Vigna sinensis e Vigna aureus, o nümero de nódulos e o peso da M. S. nodular foram reduzidos sob condiçóes salinas, em concentraçôes equivalentes a 26,55 e $145 \mathrm{mM}$ de $\mathrm{NaC} 1$. Admitiram os mesmos autores que o sal supxime a formação dos nódulos,mas o desenvolvimento posterior não é afetado. Os resultados obtidos no presente trabalho, com $5 \mathrm{mM}$ de NaCl para a colheita aos 25 dias de idade, confirmam tal observação, cujos reflexos incidiram também na atividade da nitrogenase $\left(\mathrm{N}_{2}{ }^{-a s e}\right)$. Concentrações muito elevadas de $\mathrm{NaCl}(40 \mathrm{mM})$ podem reduzir drasticamente o peso da M.S. das folhas (WIGNARAJAH et ali $i, 1975 a$ ).

Baixas doses de $\mathrm{Ca}$ afetam o metabolismo do $\mathrm{N}$, impedindo a absorção e a assimilação do nitrato, o encurvamento dos pelos ra diculares e o crescimento do filamento de infecção. O Ca interfere também na migração dos carboidratos, o que contribuiu para a baixa produção de M.S. das plantas submetidas a doses baixas. 
Por outro lado, doses excessivas dificultam a absorção da K e a fetam a disponibilidade de certos micronutrientes (MALAVolta, 1976), o que sugere uma explicação para o efeito negativo causado por doses mais elevadas de Ca $(2,5 \mathrm{mM} / 1)$.

\subsection{2 - Nitrogênio e Cälcio absorvidos}

Tendo em vista os valores de F encontrados, ocorreram diferenças altamente significativas entre Tratamentos para as variāveis \% de $\mathrm{N}$ da parte aérea, \% de $\mathrm{N}$ da raiz, \% de $\mathrm{N}$ total e mg de N/planta. A anālise de variância também revelou diferenças altamente significativas entre Idade de colheita para todas as variáveis, cujos valores de F alcançaram 516,29; 340,30 ;

1030,39 e 297,68. Registraram-se ainda diferenças altamente sig n ificativas entre Variedades para a \% de $N$ da parte aérea (F = $26,85), \%$ de $N$ da $\operatorname{raiz}(F=34,69)$ e $\%$ de $N$ total $(F=7,97)$.

Os coeficientes de variação encontrados para as quatro variáveis foram baixos, situando-se entre 9,42 e $18,03 \%$ (Tabe1a 11).

Para os porcentuais de Ca na parte aérea e na raiz (Tabe1a 11), além das diferenças altamente significativas entre tratamentos, a anālise de variância revelou diferenças altamente sig nificativas entre Idade de corte para as duas variáveis $(F=59,05$ e 192,38). A variável \% de Ca da parte aērea apresentou tambēm interação Tratamentos $x$ Variedades, significativa $(F=1,94)$, ao passo que a \% de Ca na raiz apresentou diferença altamente signi 
ficativa entre variedades $(F=7,64)$ e para a interação $T \times V$ (F $=5,16)$.

Os coeficientes de variação revelaram boa precisão experimental e se situaram entre 13,31 e $18,72 \%$ (Tabela 11-A).

Verifica-se através das Tabelas 10 e 11 que as concen trações de Ca na parte aérea e na raiz elevaram-se com o aumento das doses de Ca,tanto aos 25 como aos 45 dias de idade de colheita, ao passo que o teor de $N$ apresentou uma tendência à dimi nuição. Idênticos resultados foram obtidos por outros autores em diferentes leguminosas (LONERAGAM, 1959 ; BANATH et ali $i$ 1966; ANDREW, 1976). Os níveis de Ca e N encontrados no presente trabalho, tanto na parte aérea como na raiz, em ambos os estadios vegetativos se situam dentro dos valores encontrados por outros autores (GALLO e MIYASAKA, 1961 ; HAAG et alii, 1967 ; FRANCO e DOBEREINER, 1968 ; HIROGE et ali $i, 1970$ ).

o Ca é relativamente imóvel, não se redistribuindo com fa cilidade para o resto da planta (MALAVolta et alii, 1974), o que justifica a presença de elevadas concentrações na parte aérea e na raiz, paralelamente às altas doses aplicadas. Com relação ao $N$, cujos níveis apresentaram uma tendência à redução em presença de altas doses de Ca, pode ser sugerido um provāvel efeito de di luição do nutriente, em função da maior produção de matéria seca. 


\section{$4 \cdot 3 \cdot 3-$ Nodulação}

De acordo com os valores de F obtidos, as variäveis número de nódulos e peso médio dos nódulos apresentaram diferenças altamente significativas e razoáveis coeficientes de variação, situando-se entre 25,25 e 46,61\% (Tabela 11).

A anālise de variância revelou ainda diferenças altamente significativas para Idade de colheita para ambas as variáveis $(F=266,59$ e 467,34)!: Para a variāvel nümero de nódulos ocor reram também diferenças entre Variedades $(F=15,68)$ e para a in teração Tratamentos x Variedades $(F=2,06)$. Para a variável pe so médio dos nódulos o valor de $F(21,27)$ revelou diferenças altamente significativas entre Variedades.

Verifica-se através das Tabelas 10 e 11 , que todas as variedades responderam bem à elevação das doses de cálcio até 1,25 $\mathrm{mM}$, declinando a nodulação em função da dose mais elevada $(2,5$ mM) em ambos os estádios vegetativos, com exceção da variedade Venezuela 350 aos 45 dias de idade. O número de nódulos (dados transformados para $\sqrt{x+1,00}$ ) elevou-se de 8,815 para 11,404 (30\%), enquanto o peso médio em mg foi reduzido de 1,53 para 1,10 (30\%). Segundo LONGERI e ALLEN (1970), concentrações de Ca e Mg inferiores a $1 \mathrm{ppm} ; 0,025 \mathrm{mM} / 1$ e $0,04 \mathrm{mM} / 1$ podem comprometer o crescimento das bactérias, mas em níveis muito elevados reduzemno. Em Trifolium subterraneum, 0,035 a $0,7 \mathrm{mM}$ de $\mathrm{Ca}$ aumentou em três vezes a porcentagem de plantas noduladas e treze vezes o nú mero de nódulos/planta (LOWTHER e LONERAGAN, 1970). Concentrações de cālcio inferiores a $0,2 \mathrm{mM}$ inibiram a nodulação de Medicago sativa (MUNNS, citado por ANDREWS, 1977). 
o fato observado em relação ao declínio da nodulação com $2,5 \mathrm{mM}$ de $\mathrm{Ca}$, não pode ser atribuido, para as variedades Carioca e Rico 23, somente ao cálcio. ANDREW e JoHnSON (1976) verificaram que leguminosas muito sensíveis ao baixo $\mathrm{pH}$, tiveram pobre nodulação independente das doses de Ca $(0,125$ e 2,0 mM), o que sugere forte interação $\mathrm{pH} \times \mathrm{Ca}$. Em verdade, a variedade Venezue 1a 350 , apresentou nodulação bem inferior às demais na faixa de $\mathrm{pH}$ entre 5,0 e 6,0 para cair mais drasticamente nos valores de pH entre 6,0 e 7,0. Com relação aos níveis crescentes de $\mathrm{Ca}$ a mesma variedade respondeu linearmente ao aumento das doses. FRAN CO e DOBEREINER (1968) admitiram que doses baixas de Ca, diminuem o número mas aumentam o peso dos nódulos.

A nodulação foi afetada pelas doses mais elevadas de Ca $(2,5 \mathrm{mM} / 1)$. Tal resultado pode ser considerado normal já que acompanhou a produção de M.S. Correlações entre M.S. e nodulação são frequentemente citadas na literatura, muito embora existam diferenças entre variedades, também observadas no presente traba 1ho.

\section{3 .4 - Atividade da Nitrogenase $\left(\mathrm{N}_{2}\right.$-ase $)$}

Em função dos valores de F encontrados, como se verifica na Tabela 11, tanto a Atividade total como a Atividade específica da nitrogenase, revelaram diferenças altamente significativas entre Tratamentos ( $T$ ). Os coeficientes de variação pelas razões expostas anteriormente, foram elevados para a Atividade total $(72,19$ e $66,19 \%)$, mas satisfatórios para a Atividade específica 
da nitrogenase $(29,21$ e $24,05 \%)$. A anālise de variância tambēm revelou diferenças altamente significativas para a Atividade to tal, entre Variedades $(F=6,11)$, para a interação $T \times V \quad(F=$ 4,73 e entre Idade da colheita $(F=161,80)$. Com relação a Ati vidade específica, houve diferença apenas significativa para a interação $T \times V(F=1,98)$ e altamente significativa para Idade de colheita $(F=194,86)$.

Verifica-se através das Tabelas 10 e 11 que tanto a Ativi dade total como a Atividade específica da nitrogenase apresentaram um pico correspondente ao Tratamento de $0,25 \mathrm{mM}$ de Cálcio,on de a Atividade foi máxima para as três variedades com 45 dias de idade. Aos 25 dias de crescimento vegetativo, o pico de maior Atividade total e específica foi no tratamento correspondente a $0,5 \mathrm{mM}$ para as variedades Carioca e Rico 23. A variedade Vene zuela 350 apresentou maior Atividade total também com $0,5 \mathrm{mM}$ de Ca e maior Atividade específica com $0,05 \mathrm{mM}$. Os níveis de ção do Nitrogênio alcançados estiveram dentro dos limites obti dos nos demais experimentos e relatados por outros autores (RUSCHEL e RUSCHEL, 1975 ; HALLIDAY, 1976 ; RUSCHEL e SAITO, 1977).

Os valores obtidos para a atividade total e específica da nitrogenase, refletem, dentro de certos limites, o efeito do Ca sobre a nodulação. Algumas discrepâncias são normais e ocorrem em função do maior ou menor grau de eficiência nodular. Vários autores (LONERAGAN, 1972 ; ANDREW, 1977) relataram que a eficiên cia nodular estā sujeita a amplas variações entre estirpes de Rhizobium e variedades de plantas, em função da presença do Ca e $\mathrm{da}$ interação $\mathrm{pH} \times \mathrm{Ca}$. 


\section{3 .5 - Correlações}

A Tabela 18 demonstra todas correlações significativas es tudadas no experimento sobre níveis crescentes de Ca. Verificase na referida Tabela que existem uma correlação positiva e significativa para todas as variedades estudadas, em ambas as idades de colheita, entre\% de Ca na parte aérea $x \%$ de Ca na raiz. A variedade Venezuela 350 foi a ünica a apresentar correlação po sitiva significativa entre número de nódulos e níveis de cālcio, e entre número de nódulos e Atividade total da nitrogenase, aos 45 dias de idade. A mesma variedade apresentou isoladamente, cor relação positiva e significativa entre \% de Ca na parte aérea e número de nódulos, e entre \% de Ca na raiz e número de nōdulos, tambēm aos 45 dias de crescimento.

As três variedades estudadas apresentaram aos 45 dias de idade, correlação positiva significativa entre as Atividades total e especifica da nitrogenase.

Outra particularidade da variedade Venezuela 350 , disse respeito à correlação apresentada entre M.S. nodular e Atividade total da $\mathrm{N}_{2}$-ase aos 45 dias de desenvolvimento vegetativo. 


\section{4 - Efel to do Fösforo}

\subsection{1 - Peso da Matëria Seca (M.S.)}

Verifica-se através dos valores de F obtidos na Tabela 13, que ocorreram diferenças altamente significativas entre Tratamen tos (T), para as variáveis peso da matéria seca da raiz e peso a M.S. nodular. Os coeficientes de variação foram baixos e se situaram entre 20,19 e $36,62 \%$ (Tabela 13). As variáveis peso da M.S. da parte aérea e peso da M.S. total não apresentaram diferenças entre Tratamentos.

A anālise de variância revelou ainda diferenças altamente significativas entre Variedades (V) e entre Idade de colheita, com valores de F, 6,07 e 362,09 para a M.S. da parte aérea; para a M.S. da raiz, com valores de F alcançando 7,87 e 265,33; com relação à M.S. nodular ocorreram diferenças altamente significativas para a interação $T \times V(F=3,41)$ e entre Idade de colheita $(F=510,22)$; também o peso da M.S. total apresentou diferenças altamente significativas entre Variedades $(F=5,45)$ e entre Idade de colheita $(F=420,50)$.

Verifica-se através das Tabelas 12 e 13 que as variedades estudadas responderam à aplicação de doses crescentes de $P$, mas não apresentaram resposta linear; além do mais o comportamento entre Variedades dentro de um mesmo tratamento foi bastante diferente em ambas as idades de colheita. Respostas à aplicação de fósforo na produção da matéria seca, são comuns na literatura. 
ocorre, que as doses empregadas no experimento forambaixas, situando-se entre 0,31 e $18,75 \mathrm{ppm}$. GOEPFERT (1972) obteve correlação linear entre o rendimento do feijoeiro e doses crescentes de P até 20 ppm. Com doses mais elevadas värios autores obtiveram maiores produções de matëria seca (Kolling et alii, 1974; WHITEAKER et ali $i$, 1976).

0 fósforo desempenha papel importante na fotossintese como fonte geradora de energia sob a forma de ATP, além de estimular e enraizamento e o perfilhamento das plantas. As melhores respostas com relação às doses de P estudadas, foram ohtidas na 1 . colheita, aos 25 dias de idade, o que confirma relatos de vários autores sobre a maior importância da adubação fosfatada no estabelecimento, ou seja nas primeiras fases de crescimento das plan tas (JONES, 1974 ; WHITEAKER et alii, 1976).

\subsection{2 - Nitrogênio e fósforo absorvidos}

Na Tabela 13-A, verifica-se que todas as variáveis relacionadas com teores de $\mathrm{P}$ e $\mathrm{N}$, e $\mathrm{N}$ total absorvido, apresentaram diferenças altamente significativas entre Tratamentos (T) e apre sentaram baixos coeficientes de variação (C.V.), indicando boa precisão experimental. A anālise de variância revelou ainda diferenças significativas entre Variedades (V) para \% de $N$ da parte aérea $(F=5,60), \%$ de $N$ da raiz $(F=38,29), \%$ de $N$ total ( $F$

$=11,37)$, mg de $N / p l a n t a ~(F=3,38)$, \% de P na parte aérea $(F=$ $9,36)$ e \% de $P$ na raiz $(F=4,57)$. As variāveis \% de $P$ na parte 
aérea, \% de $P$ na raiz e mg de N/planta apresentaram diferenças altamente significativas entre idade de colheita, cujos valores de F foram, respectivamente, $1.216,53 ; 186,97$ e 543,70 . A interação $T \times V$ apresentou diferenças significativas para todas as variáveis, com exceção de mg de N/planta, e os valores de F se situaram entre 2,11 e 10,78 .

Vários autores admitiram que os teores de $N$ e $P$ da parte aérea aumentam com as doses crescentes de fósforo aplicadas (ANDREW e ROBINS, 1969 ; JONES, 1974 ; KOLLING et alii, 1976). No presente trabalho tal fato ocorreu somente em relação à porcenta gem de $P$, como se verifica nas Tabelas 12 e 13 . A quantidade de $N$ total absorvido, sendo função do teor de $N$ e do peso da matéria seca, manteve-se dentro do comportamento dessas duas variáveis. SAITo e RUSCHEL (1976) também não obtiveram aumento do teor de $N$ da parte aérea do feijoeiro decorrente da presença do fósforo, embora a nodulação tenha sido favorecida.

Segundo ANDREWS (1977) existem poucos dados com experimen tos detalhados que expliquem a relação entre níveis de $\mathrm{P}$ e \% de $N$ na parte aérea acompanhada de uma maior produção de matéria se ca. Com efeito, EIRA et ali $i$, citados pelo referido autor estudaram a influência do fósforo em várias leguminosas tropicais, verificando que $M$. atropurpureum apresentou aumento no teor de $\mathrm{N}$, enquanto $G$. wightii e $S$. gracilis tiveram redução. os teores de $N$ e $P$ no presente ensaio situaram-se nos limites encontra dos na literatura (ALMEIDA et alii, 1973 ; AMARAL, 1975). 
A não elevação dos teores de $N$ em decorrência do aumento das doses de $P$, amplamente registrada na literatura, pode ser atribuida à insuficiência da simbiose Leguminosa - Rhizobium, ou à baixa ação sinérgica do $N$, uma vez que o crescimento da planta, avaliado através do peso da M.S. também foi afetado.

\section{$4.4 .3-$ Nodulação}

A luz dos valores de F encontrados (Tabela 13), tanto o número de nódulos como o peso médio dos nódulos apresentaram diferenças altamente significativas ( $1 \%$ ) entre tratamentos, enquan to os coeficientes de variação encontrados foram baixos para a variável número de nódulos $(21,51$ e $22,17 \%)$ e altos $(69,35$ e 77,54) para o seu peso médio.

A anālise de variância revelou ainda diferenças altamente significativas entre Variedades e Idade de colheita (F = 15,27 e 97,52) para número de nódulos, e significativas $(F=3,75)$ e altamente significativas $(F=37,56)$ para Variedades e Idade de co lheita com relação ao peso médio.

Verifica-se através das Tabelas 12 e 13, que o fósforo influenciou a nodulação nas duas idades de colbeita, muito embora a resposta: não tenha sido linear. Värios autores relataram aumento do número de nódulos e do peso com a elevação do suprimento de fósforo (MOOY e PESEK, 1966 ; ALMEIDA et alii, 1973; SAI TO e RUSCHEL, 1976 ; ANDREW, 1977). 
A nodulação, dentro de certos limites, acompanhou o desen volvimento da planta, o que jä era esperado. 0 suprimento de $P$ gerou energia sob a forma de ATP, transferiu parte dessa energia para atender o crescimento da planta, mas a quantidade restante não foi suficiente para uma maior nodulação, o que justifica serem as leguminosas bastante exigentes em fósforo.

4.4 .4 - Atividade da Nitrogenase $\left(\mathrm{N}_{2}\right.$-ase $)$

Considerando-se os valores de F obtidos e apresentados na Tabela 13, registraram-se diferenças altamente significativas en tre Tratamentos ( $T$ ), para as variāveis Atividade total e Ativida de especifica da nitrogenase.

A anālise de variância revelou ainda diferença significativa entre Variedades $(F=3,95)$ para a Atividade total da $\mathrm{N}_{2}$-ase, entre Idade de colheita $(F=68,03)$ e para a interação Tratamentos $x$ Variedades $(F=2,08)$ para a variável Atividade específica da nitrogenase. Os coeficientes de variação estiveram dentrodos limites permissiveis para a natureza do experimento e as variaveis em estudo, e se situaram entre 28,58 e $67,38 \%$.

Verifica-se atravēs das Tabelas 12 e 13 , que a fixação de N alcançou valores maiores com as doses mais elevadas de fósforo. Tais resultados jä eram esperados uma vez que tanto o peso da M.S. nodular como o número de nódulos tiveram idêntico comportamento. Na maioria dos casos, o $N$ fixado, está na dependência do tecido nodular formado (DOBEREINER et alii, 1966), mas o número de nódu 
los nem sempre é um bom indice de avaliação da eficiência da sim biose (FRANCO e DOBEREINER, 1968).

os níveis de fixação de $N$, avaliada através da Atividade da nitrogenase, estiveram dentro dos limites relacionados nos demais experimentos e confirmados por outros autores (GRAHAM e HALLIDAY, 1976 ; RUSCHEL e SAITO, 1977).

A atividade da nitrogenase tambēm foi comprometida pelo su primento de $P$, mas se manteve dentro do potencial da massa nodular formada. Os resultados obtidos corroboram relatos de diversos autores (DOBEREINER et alii, 1966) e demonstram a necessidade de avaliação do estudo nutricional da planta, já que o grau de absorção do $P$ e tambēm do $N$ e $K$ está na dependência da idade da planta, o que justifica o emprego da adubação fosfatada parce lada, isto ê, na formação, e depois, em cobertura.

\section{4 .5 - Correlações}

A Tabela 19 revela as variáveis que foram estudadas para efeito de correlação. Verifica-se que as variāveis, Peso da $M$. S. total e Peso da M.S. nodular não apresentaram correlação significativa com os níveis de fósforo estudados aos 25 e 45 dias de crescimento vegetativo. Por outro lado, observa-se que a Atividade específica da nitrogenase não revelou correlação significativa para nenhuma das variedades estudadas, com os níveis de $P$ aplicados nas duas idades de colheita (Tabela 19). 
Com relação à Atividade total da $\mathrm{N}_{2}$-ase e as doses de $\mathrm{P}$, constata-se através da Tabela 19, que houve correlação positiva e significativa para a variedade Carioca. Ainda na mesma Tabela, verifica-se que a variedade Carioca apresentou correlação significativa entre M.S. nodular x M.S. total nas duas colheitas efetuadas.

A variedade Venezuela 350 isoladamente, apresentou aos 25 e 45 dias de idade, correlação significativa entre nümero de nódulos e Atividade total da nitrogenase. A variedade Rico 23 apresentou uma única correlação, Atividade total x Atividade espe cífica, quando colhida com 25 dias de idade.

Vārios autores obtiveram correlações idênticas, estudando leguminosas tropicais submetidas a níveis crescentes de fósforo. ALMEIDA et alii (1973) obtiveram correlação linear significativa entre peso da M.S. nodular e níveis de fósforo. KOLLING et alii relataram uma correlação significativa entre o peso da M.S. total, em siratro e desmódio submetidas a níveis crescentes de fós foro. Os mesmos autores obtiveram ainda correlação significativa com as duas leguminosas forrageiras, entre peso da M.S. dos nódulos $x$ mg de N/planta. MOOY e PESEK (1966) relataram a existência de correlação significativa entre níveis de fósforo e nümero de nódulos, e entre peso da matéria fresca nodular e níveis de fósforo. 
4.5 - Efeito do Aluminio manganês na solução nutritiva e au sência de Ferro e Molibdênio

4.5 .1 - Peso da Matéría seca (M.S.)

Verifica-se através da Tabela 15, consoante os valores de F encontrados, que registraram-se diferenças altamente significa tivas entre Tratamentos (T), para as variáveis Peso da matéria seca da parte aérea, da raiz, dos nódulos e peso da M.S. total. os coeficientes de variação (C.V.) foram satisfatörios em função dos tratamentos aplicados, situando-se entre 19,53 e $41,32 \%$.

Por outro lado, a anālise de variância revelou ainda dife renças entre Variedades $(V), F=4,88$, entre Idade de colheita $(F=29,54)$, e para a interação $T \times V(F=3,59)$, com relação variável M.S. da parte aérea. Para o peso da M.S. da raiz, tive mos diferenças altamente significativas entre Idade de colheita $(F=95,17)$ e entre Variedades $(V)$, onde F alcançou 21,77. A in teração $T \times V$ também registrou diferenças significativas （F= 2,04). A produção de M.S. nodular apresentou diferenças altamente significativas apenas entre as colheitas $(F=201,61)$, enquan to a M.S. total revelou diferenças entre Variedades $(F=86,92)$, entre Idade de colheita $(F=71,79)$ e.para a interação $T \times V$. $(F=$ $2,15)$.

Verifica-se através das Tabelas 14 e 15 , que o peso da ma téria seca das diferentes partes vegetativas do feijoeiro foi drasticamente afetado pela presença do Al e do Mn, em grau mais ou menos acentuado, em função da concentração dos referidos elementos na solução nutritiva. 
A influência do Al sobre o desenvolvimento da planta, prin cipalmente os danos causados à raiz, é reconhecida por vārios au tores (FOY et alii, 1967 ; RUSCHEL et ali $i, 1968$; MALAVOLTA, 1976). Segundo ANDREW (1977), parte dos trabalhos realizados en volve elevadas concentrações de Al na solução (40 a 50 ppm), o que torna pouco em comum com os níveis encontrados na solução do solo, que raramente excedem de $4 \mathrm{ppm}$.

As diferenças registradas no presente trabalho com relação às variedades e a tolerância do Al, são comumente registra das na literatura (KAMPRAth e FOY, 1971). Com 2 ppm de Al, D. uncinatum reduziu significativamente seu crescimento, enquanto M. Lathyroides, L. bainesii e S. humilis, não tiveram a produção de M.S. afetada.

Verifica-se ainda que a parte aérea foi mais afetada do que a raiz, em relação ao peso da matéria seca (M.S.) da varieda de Venezuela 350 , que apresentou reduções de 61,3 e $60 \%$, respectivamente, confirmando relato de värios autores (RUSCHEL et ali 1968 ; ANDREW e BERG, 1973). As elevadas reduções obtidas referem-se às doses mais elevadas de Al (10 ppm). Com 7 ppm, RusCHEL et ali $i$ (1968) registraram diferenças de 45 e $44 \%$, respecti vamente para a parte aérea e raiz, enquanto foy et alii com 8 ppm, detectaram reduções de 47 e $41 \%$ para ambas as partes da planta.

Todas as variedades estudadas apresentaram elevadas concentrações de Al, tanto para parte aérea, como na raiz, cujos va lores segundo REIS (1978), alcançaram 640 a 1.020 ppm, e 1.550 a $6.430 \mathrm{ppm}$, respectivamente. Concentrações tambēm bastante e- 
levadas foram observadas por RUSCHEL et alii (1968) com 1 a 7 ppm de Al, onde os nümeros elevaram-se de 200 a 900 ppm na parte aérea e 1.300 a 9.500 ppm na raiz.

Observa-se nas Tabelas 14 e 15 , que todas as variảveis es tudadas em relação ao peso da M.S. foram severamente prejudicadas pela presença do $M n(10$ e 20 ppm) na solução, principalmente a massa nodular que atingiu valores iguais a zero (0). A variedade Venezuela 350 aos 45 dias de idade, foi a mais prejudicada, com reduções de 87 e $89 \%$, respectivamente para o peso da M.S. da parte aérea e da raiz. ANDREW e HEGARTY (1969) relataram maiores reduções na parte aérea do que na raiz, enquanto souto e DoBEREINER (1969) admitiram que a M.S. nodular foi mais atingida do que o número de nódulos. Com 40 ppm de Mn, o crescimento do feijão e da soja foram também bastante afetados DOBEREINER, 1966).

o ensaio sobre manganês, revelou nas primeiras semanas, evidentes sintomas de toxidez, os quais evoluiram rapidamente pá ra uma sintomatologia característica de deficiência de Fe induzi da pelo excesso de Mn, confirmando assim os relatos de diferentes autores (SOMERS e SHIVE, 1942 ; MALAVOLTA et ali $i, 1974$; MALAVOLTA, 1976 ).

Com relação às ausências do Fe e do Mo, verifica-se (Tabe las 14 e 15), que somente aos 45 dias o peso da matéria seca foi afetado. Todavia, nenhum sintoma característico da deficiên cia desses micronutrientes, foi apresentado pelas plantas, o que nos levou a inferir que fatores outros adversos, principalmente a infestação maciça de ácaros brancos, tenha comprometido o de- 
senvolvimento da planta. Com efeito, as folhas ficaram bastante afetadas, perderam a cor verde característica da presença da clo rofila, comprometendo evidentemente, o suprimento de produtos da fotosintese.

Os carboidratos sintetizados podem ser utilizados diretamente para o crescimento da parte aérea, ou translocados para manter o metabolismo das raízes e nódulos, imprescindíveis à fixação do nitrogênio.

As condições experimentais não nos permitem afirmar categoricamente, que as plantas estiveram em completa ausência de Fe, não obstante o emprego de āgua diionizada no preparo da solução.

Tais restrições também são feitas para o tratamento menos. Mo. Ocorre, que värios autores (MEACHER et ali $i, 1952$; HEWITT e SMITH, 1975) admitiram que as reservas de Mo presentes na semente, ultrapassam em dez vezes o total necessärio ao crescimento da planta, podendo inclusive persistir por duas gerações. Anälises procedidas por DANTAS (1978) revelaram existir 0,62 a $1,64 \mathrm{ppm}$ de Mo nas sementes das variedades estudadas. 0 referi do pesquisador revelou que o feijoeiro aos 45 dias, apresentou 0,50 a 1,94 ppm na parte aérea e 0,41 a 0,53 ppm na raiz; aos 25 dias os valores alcançaram 0,64 a 0,97 e 0,79 a 1,36 ppm, respec tivamente.

Plantas supridas com 1 a 5 ppm de Mo, são consideradas su ficientemente supridas (JONES, 1968). 


\subsection{2 - Nodulação e Atividade da Nitrogenase}

Os valores de F obtidos no experimento (Tabela 15) revela ram diferenças altamente significativas entre Tratamentos (T) pa ra as variáveis número de nódulos, peso médio dos nódulos, ativi dade total e atividade específica da nitrogenase. Os coeficientes de variação apresentados na mesma Tabela, se situaram entre 23,02 e $59,03 \%$. Para a variável número de nódulos, também ocor reram diferenças significativas entre Variedades $(F=8,58)$ e pa ra a interação Tratamentos x Variedades $(F=2,52)$. Para o peso médio, a análise de variância detectou diferenças entre variedades $(F=10,97)$; entre Idade de colheita $(F-119,61)$ e para a interação $T \times V(F-5,08)$. A análise de variância revelou ain da diferenças altamente significativas entre variedades para as variáveis Atividade total $(F=5,08)$ e Atividade específica da $\mathrm{N}_{2}$-ase $(\mathrm{F}=5,99)$, e entre Idade de colheita $(\mathrm{F}=53,65$ e 825,41$)$ para ambas as variáveis.

A presença do Al afetou a nodulação e a fixação de N, sen do que aos 45 dias,não obstante a presença de grande nümero de nódulos de elevado peso médio (Tabela 15), não houve fixação de nitrogênio, revelando ineficiência nodular em relação à atividade da nitrogenase.

os danos causados pelo Al à raiz, reduzindo a nodulação e comprometendo a simbiose leguminosa Rhizobium, além de inibir o desenvolvimento dos pelos radiculares, impedem evidentemente a fixação de nitrogênio (RORISON, citado por RUSCHEL et alii, 1968 ; KAMPRATH e FOY, 1971 ). 
$0 s$ niveis de Mn estudados (10 e 20 ppm) inibiram completa mente a nodulação e a atividade da nitrogenase, como se verifica nas Tabelas 14 e 15 .

Verifica-se através da Tabela 14 , que as ausências do Fe e do Mo não afetaram a nodulação, nem a fixação do nitrogênio das variedades de Phaseolus vulgaris estudadas, aos 25 dias de crescimento vegetativo. Na 2 . colheita, a nodulação foi bantante afetada em ambos os tratamentos, quando comparados com o tratamento completo.

A luz dos argumentos levantados no ítem anterior com rela ção às condições experimentais da casa de vegetação, hä evidên cias para se sugerir que a não fixação de $N$ do tratamento menos Fe foi devida à redução do suprimento de carboidratos da parte aérea para o sistema radicular.

Com relação ao molibdênio, há fortes evidências para se sugerir que o suprimento existente nas sementes foi suficiente para assegurar a nodulação e a fixação do $N$, avaliada através da atividade da nitrogenase. Relatou ANDREW (1962), que as quantidades de Mo exigidas para a fixação simbiótica do N atmosférico, são bem superiores àquelas exigidas para o próprio crescimento da leguminosa. Plantas deficientes em Mo, apresentam pouca nodula ção, aumento do tamanho dos nódulos e alteração da sua cor e for mato (KLIEWER e KENNEDY, 1960 ; FREIRE e VIDOR, 1971), o que não foi verificado no presente trabalho. Segundo WERNER e MATTOS (1974), a adição de $0,250 \mathrm{~kg} / \mathrm{ha}$ de Mo, proporcionou à soja perene, variedade comum (Glycine wightii willd.) aumentos signifi- 
cativos na produção de M.S., peso dos nódulos, \% de N e produção de $\mathrm{N}$ total por vaso. Empregando $5 \mathrm{~kg} / \mathrm{ha}$ de molibdato de sódio, RUSCHEL et alii (1966) relataram que o molibdênio diminuiu o nümero de nódulos, mas aumentou a quantidade de $\mathrm{N}$ fixado por nódu10. Em outro ensaio, onde o Mo foi aplicado ao revestimento da semente, RUSCHEL et alii (1969) relataram que o Mo aumentou significativamente o nitrogênio porcentual e total da planta.

\section{$4.5 .3-$ Correlações}

Objetivando mais levantar hipóteses para futuros trabalhos do que tirar conclusões definitivas, procedeu-se um estudo compa rativo de todas as variáveis estudadas neste experimento e as possíveis correlações existentes entre si. Considerando a profundidade do trabalho, apresentamos através das Tabelas 20 a 26 , todas as correlaçóes significativas encontradas em uma ou outra idade de colheita, nas três variedades de feijoeiro estudadas. Vários autores (RUSCHEL et alii, 1966 ; RUSCHEL et alii, 1969 ; BORGES et ali $i$, 1974 ; WERNER e MATTOS, 1974 ; SAITO e RUSCHEL, 1977) relataram a existência de interações significativas entre macro e micronutrientes, e entre värios micronutrientes, o que sugere a necessidade de estudos amplos e completos com ensaios de subtração, baseados sempre na análise do sistema solo-planta para determinação das exigências nutricionais da planta. Segundo Malavolta (1976), a relação entre micronutrientes, matéria or gânica e microrganismos é um campo quase totalmente inexplora- 
do, por falta de conhecimento da estrutura completa dos ácidos $\underline{\underline{u}}$ micos e fülvico e da velocidade de decomposição e renovação desses materiais no solo.

Todavia, o conhecimento das funções dos micronutrientes no metabolismo, seja associado com microrganismos, plantas ou animais avançou consideravelmente nos ültimos dez anos; sua parti cipação nos eventos metabólicos mais importantes, tais como respiração, fotossintese, fixação de $N_{2}$ e assimilação de nitratos e sulfatos, é sem dúvida, evidente (NICHOLAS, 1975).

Verifica-se nas Tabelas 20 a 26 , que de um modo geral, o peso da M. S. nodular e o peso da M. S. total representam parâme tros valiosos na avaliação da fixação do nitrogênio, e esta segue o desenvolvimento da planta, diminuindo à medida que a fun ção clorofiliana vai cessando (DOBEREINER et alii, 1966 ; RUSCHEL e REUS ZER, 1973 ). 


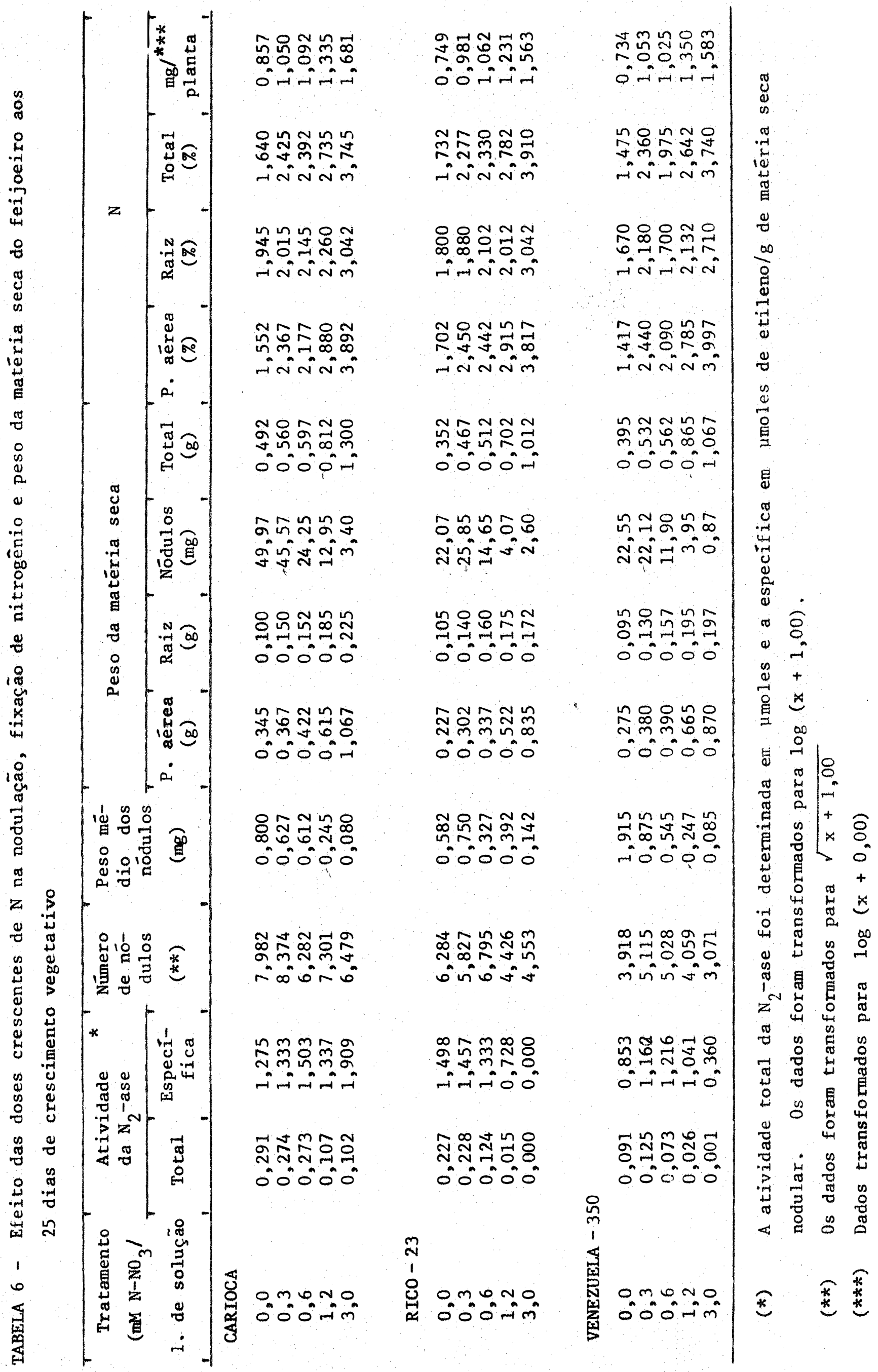




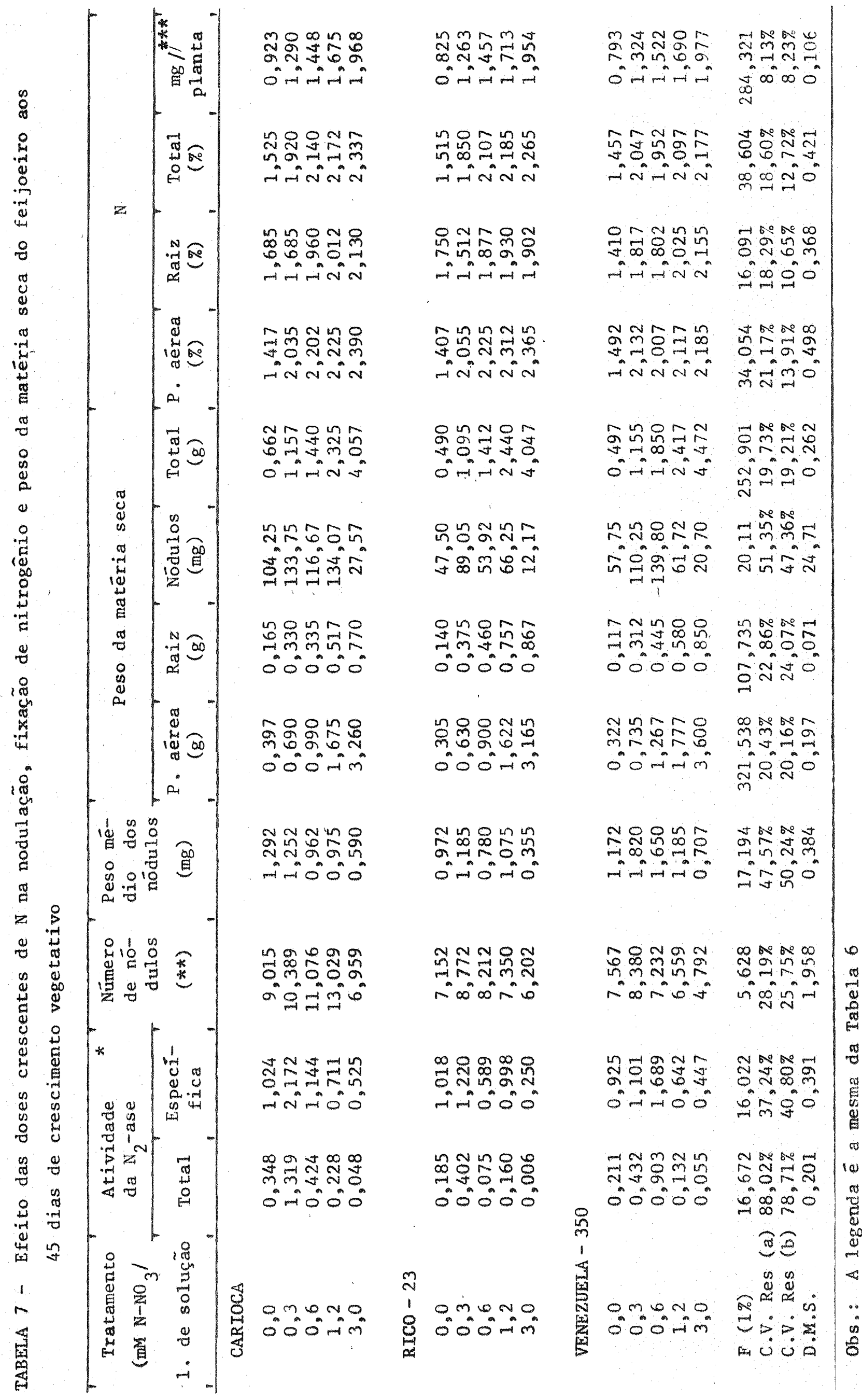




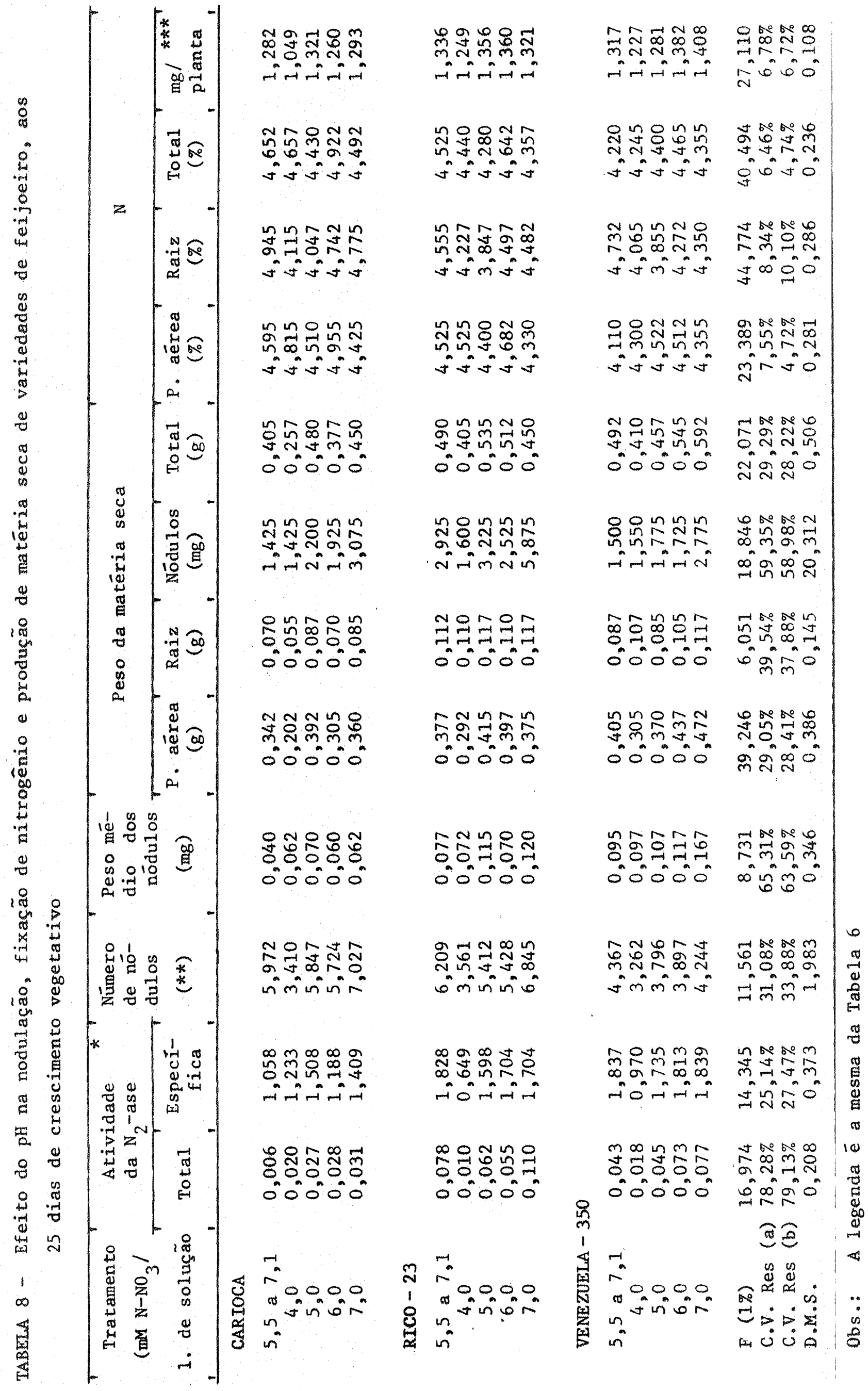




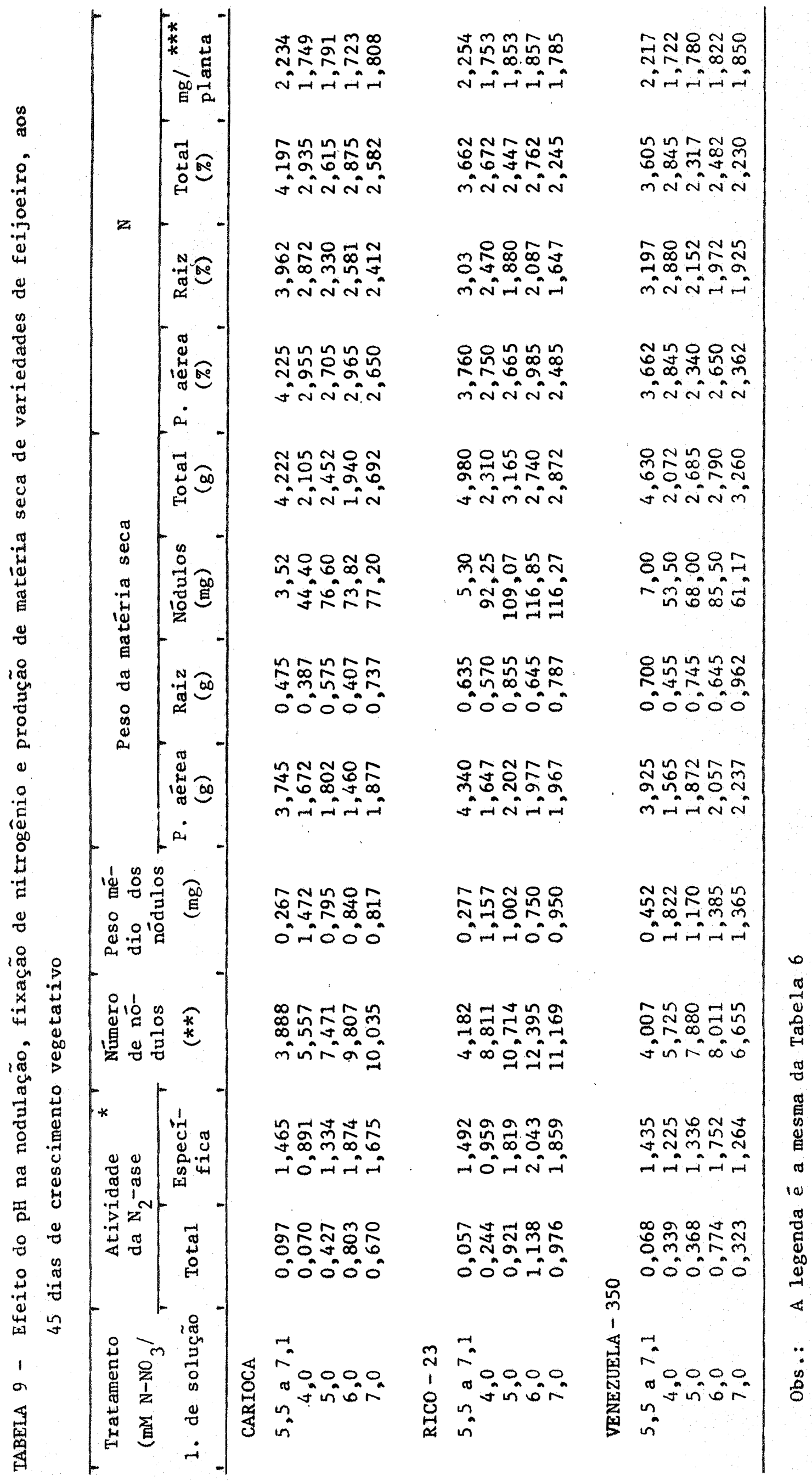




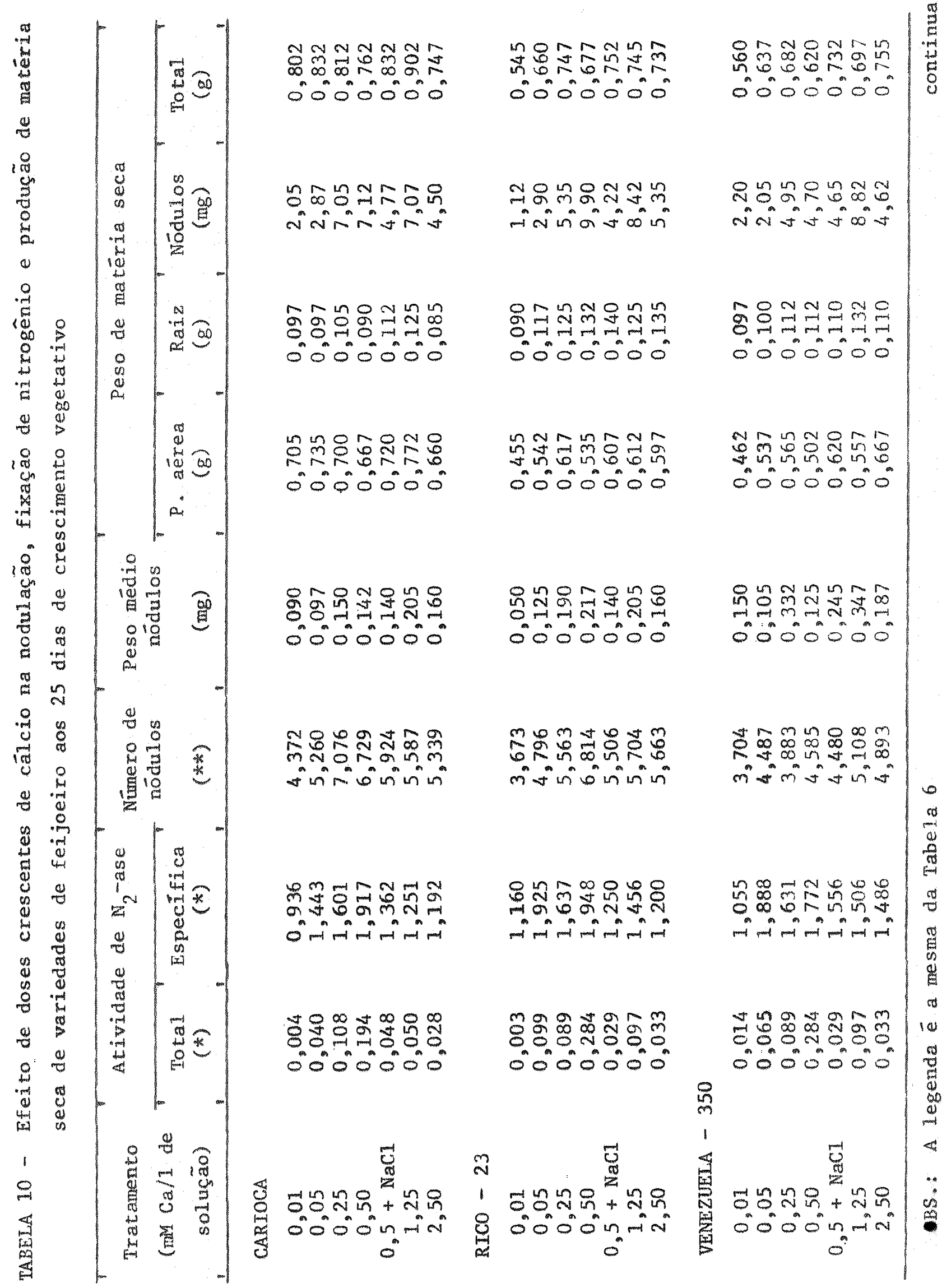


TABELA 10 - Continuação

\begin{tabular}{|c|c|c|c|c|c|c|}
\hline \multirow{2}{*}{$\begin{array}{l}\text { Tratamento } \\
\text { (mM Ca/1. } \\
\text { de soluçäo }\end{array}$} & \multicolumn{2}{|c|}{$\mathrm{Ca}$} & \multicolumn{4}{|c|}{$\mathrm{N}$} \\
\hline & $\begin{array}{c}\text { P.érea } \\
(\%)\end{array}$ & $\begin{array}{l}\text { Raiz } \\
(\%)\end{array}$ & $\begin{array}{c}\text { P. aérea } \\
(\%)\end{array}$ & $\begin{array}{l}\text { Raiz } \\
(\%)\end{array}$ & $\begin{array}{c}\text { Total } \\
(\%)\end{array}$ & $\begin{array}{c}\mathrm{mg} / \mathrm{planta} \\
(* * *)\end{array}$ \\
\hline \multicolumn{7}{|l|}{ CARIOCA } \\
\hline $\begin{array}{c}0,01 \\
0,05 \\
0,25 \\
0,50 \\
0,5+\mathrm{NaC1} \\
1,25 \\
2,50\end{array}$ & $\begin{array}{l}0,615 \\
0,877 \\
2,155 \\
2,140 \\
2,415 \\
2,677 \\
2,925\end{array}$ & $\begin{array}{l}0,662 \\
0,635 \\
0,925 \\
1,625 \\
1,222 \\
1,390 \\
1,617\end{array}$ & $\begin{array}{l}4,180 \\
3,902 \\
4,247 \\
4,142 \\
4,222 \\
4,247 \\
4,005\end{array}$ & $\begin{array}{l}5,037 \\
3,882 \\
3,037 \\
3,745 \\
3,230 \\
2,877 \\
3,630\end{array}$ & $\begin{array}{l}4,282 \\
3,827 \\
4,087 \\
3,045 \\
4,090 \\
4,062 \\
4,035\end{array}$ & $\begin{array}{l}1,547 \\
1,523 \\
1,529 \\
1,501 \\
1,541 \\
1,564 \\
1,480\end{array}$ \\
\hline \multicolumn{7}{|l|}{ RICO - 23} \\
\hline $\begin{array}{c}0,01 \\
0,05 \\
0,25 \\
0,50 \\
0,5+\mathrm{NaC1} \\
1,25 \\
2,50\end{array}$ & $\begin{array}{l}0,630 \\
0,900 \\
1,745 \\
1,982 \\
2,150 \\
2,585 \\
2,925\end{array}$ & $\begin{array}{l}0,565 \\
0,702 \\
1,040 \\
1,495 \\
1,142 \\
1,505 \\
1,647\end{array}$ & $\begin{array}{l}3,495 \\
3,912 \\
3,900 \\
3,790 \\
4,222 \\
4,247 \\
4,005\end{array}$ & $\begin{array}{l}3,845 \\
3,070 \\
2,377 \\
3,035 \\
2,852 \\
2,367 \\
2,762\end{array}$ & $\begin{array}{l}3,535 \\
3,762 \\
3,642 \\
3,640 \\
3,780 \\
3,460 \\
3,792\end{array}$ & $\begin{array}{l}1,290 \\
1,411 \\
1,434 \\
1,400 \\
1,461 \\
1,422 \\
1,457\end{array}$ \\
\hline \multicolumn{7}{|c|}{ VENEZUELA - 350} \\
\hline $\begin{array}{c}0,01 \\
0,05 \\
0,25 \\
0,50 \\
0,5+\mathrm{NaCl} \\
1,25 \\
2,50\end{array}$ & $\begin{array}{l}0,480 \\
1,125 \\
1,835 \\
2,140 \\
2,412 \\
2,585 \\
2,772\end{array}$ & $\begin{array}{l}0,472 \\
1,007 \\
0,900 \\
1,522 \\
0,877 \\
1,222 \\
1,560\end{array}$ & $\begin{array}{l}3,927 \\
4,030 \\
3,507 \\
3,890 \\
4,210 \\
3,577 \\
3,777\end{array}$ & $\begin{array}{l}4,240 \\
3,740 \\
2,727 \\
3,520 \\
2,865 \\
2,135 \\
2,860\end{array}$ & $\begin{array}{l}3,985 \\
3,985 \\
3,372 \\
3,822 \\
3,995 \\
3,295 \\
3,645\end{array}$ & $\begin{array}{l}1,356 \\
1,420 \\
1,374 \\
1,365 \\
1,479 \\
1,371 \\
1,467\end{array}$ \\
\hline
\end{tabular}

OBS.: A legenda é a mesma da Tabela 6 


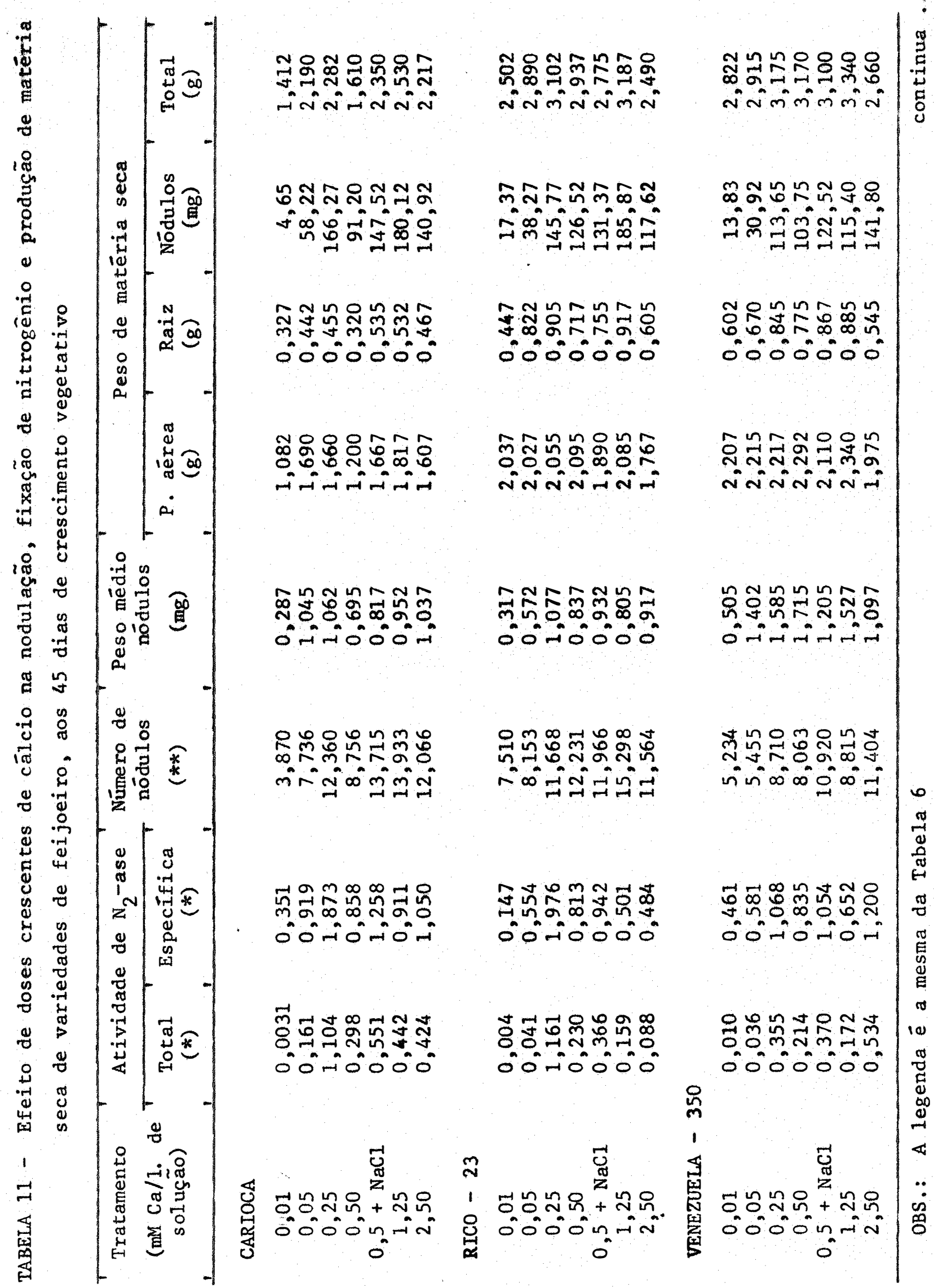




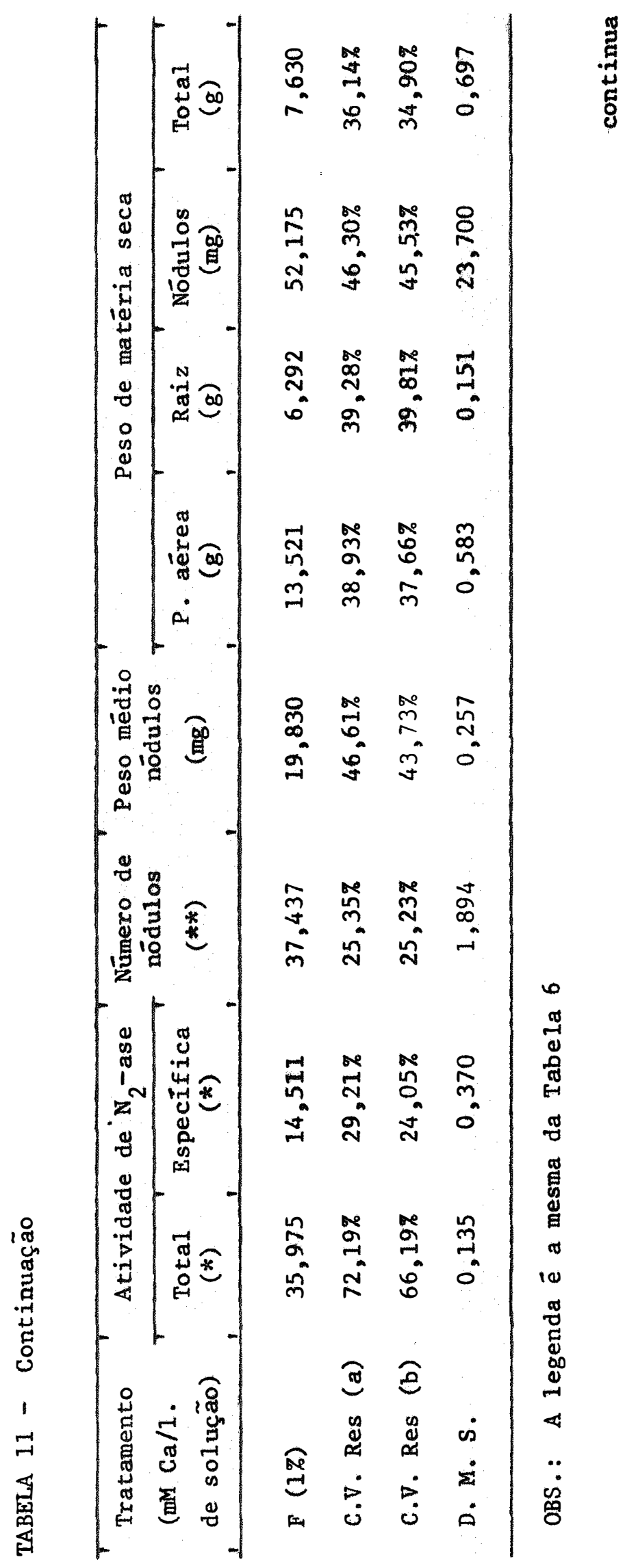


TABELA 11 - Continuação

\begin{tabular}{|c|c|c|c|c|c|c|}
\hline Tratamento & \multicolumn{2}{|c|}{$\mathrm{Ca}$} & \multicolumn{4}{|c|}{$\mathbf{N}$} \\
\hline $\begin{array}{l}\text { (mM } \mathrm{Ca} / 1 \text {. } \\
\text { de solução) }\end{array}$ & $\begin{array}{c}\text { P. aérea } \\
(\%)\end{array}$ & $\begin{array}{l}\text { Raiz } \\
(\%)\end{array}$ & $\begin{array}{c}\text { P. aérea } \\
(\%)\end{array}$ & $\begin{array}{l}\text { Raiz } \\
(\%)\end{array}$ & $\begin{array}{c}\text { Total } \\
(\%)\end{array}$ & $\underset{(* * *)}{\mathrm{mg} / \mathrm{planta}}$ \\
\hline \multicolumn{7}{|l|}{ CARIOCA } \\
\hline $\begin{array}{c}0,01 \\
0,05 \\
0,25 \\
0,50 \\
0,5+\mathrm{NaCl} \\
1,25 \\
2,50\end{array}$ & $\begin{array}{l}0,775 \\
1,000 \\
1,675 \\
1,942 \\
2,987 \\
3,060 \\
3,605\end{array}$ & $\begin{array}{l}0,745 \\
0,935 \\
1,575 \\
0,845 \\
1,325 \\
2,390 \\
2,840\end{array}$ & $\begin{array}{l}3,365 \\
2,622 \\
3,057 \\
2,457 \\
2,857 \\
3,292 \\
2,927\end{array}$ & $\begin{array}{l}3,272 \\
2,702 \\
2,335 \\
1,922 \\
2,235 \\
2,275 \\
2,227\end{array}$ & $\begin{array}{l}3,345 \\
2,640 \\
2,897 \\
2,345 \\
2,902 \\
3,065 \\
2,507\end{array}$ & $\begin{array}{l}1,626 \\
1,754 \\
1,777 \\
1,352 \\
1,775 \\
1,848 \\
1,762\end{array}$ \\
\hline \multicolumn{7}{|l|}{ RICO - 23} \\
\hline $\begin{array}{c}0,01 \\
0,05 \\
0,25 \\
0,50 \\
0,5+\mathrm{NaC1} \\
1,25 \\
2,50\end{array}$ & $\begin{array}{l}0,950 \\
1,000 \\
1,767 \\
2,272 \\
2,912 \\
3,557 \\
3,355\end{array}$ & $\begin{array}{l}0,967 \\
0,885 \\
1,865 \\
1,902 \\
1,720 \\
2,790 \\
2,862\end{array}$ & $\begin{array}{l}2,890 \\
2,110 \\
2,817 \\
2,452 \\
2,315 \\
2,430 \\
2,507\end{array}$ & $\begin{array}{l}3,042 \\
2,402 \\
2,120 \\
2,175 \\
2,032 \\
1,825 \\
1,857\end{array}$ & $\begin{array}{l}2,915 \\
2,187 \\
2,622 \\
2,382 \\
2,702 \\
2,250 \\
2,332\end{array}$ & $\begin{array}{l}1,861 \\
1,799 \\
1,882 \\
1,827 \\
1,776 \\
1,834 \\
1,743\end{array}$ \\
\hline \multicolumn{7}{|c|}{ VENEZUELA - 350} \\
\hline $\begin{array}{c}0,01 \\
0,05 \\
0,25 \\
0,50 \\
0,5+\mathrm{NaCl} \\
1,25 \\
2,50\end{array}$ & $\begin{array}{l}0,972 \\
1,012 \\
2,115 \\
2,365 \\
2,985 \\
2,490 \\
3,357\end{array}$ & $\begin{array}{l}0,840 \\
1,192 \\
1,437 \\
1,690 \\
1,150 \\
2,190 \\
2,765\end{array}$ & $\begin{array}{l}2,377 \\
2,257 \\
2,287 \\
2,455 \\
2,280 \\
2,060 \\
2,220\end{array}$ & $\begin{array}{l}2,720 \\
2,300 \\
1,935 \\
2,165 \\
1,715 \\
1,847 \\
1,945\end{array}$ & $\begin{array}{l}2,440 \\
2,270 \\
2,190 \\
2,385 \\
2,117 \\
2,002 \\
2,162\end{array}$ & $\begin{array}{l}1,825 \\
1,811 \\
1,827 \\
1,867 \\
1,781 \\
1,807 \\
1,740\end{array}$ \\
\hline $\begin{array}{l}\text { F (1\%) } \\
\text { C.V. Res (a) } \\
\text { C.V. Res (b) } \\
\text { D.M.S. }\end{array}$ & $\begin{array}{r}239,700 \\
13,31 \% \\
14,09 \% \\
0,308\end{array}$ & $\begin{array}{r}144,213 \\
14,50 \% \\
18,72 \% \\
0,223\end{array}$ & $\begin{array}{r}19,842 \\
11,34 \% \\
11,03 \% \\
0,408\end{array}$ & $\begin{array}{c}65,461 \\
13,12 \% \\
11,44 \% \\
0,404\end{array}$ & $\begin{array}{r}11,207 \\
18,03 \% \\
7,67 \% \\
0,626\end{array}$ & $\begin{array}{r}7,492 \\
10,03 \% \\
9,42 \% \\
0,176\end{array}$ \\
\hline
\end{tabular}

OBS.: A legenda ē a mesma da Tabela 6 


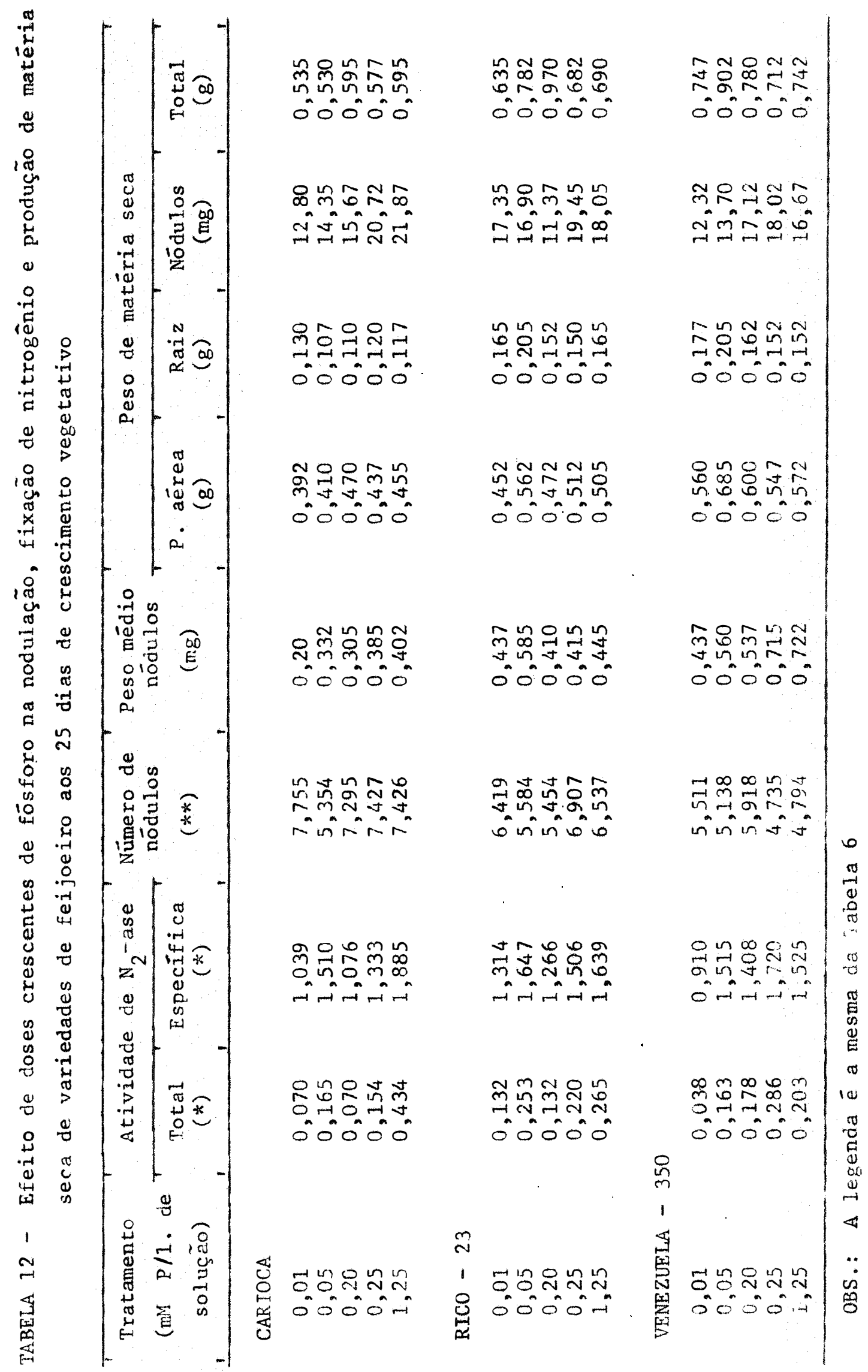


TABELA 12 - Continuação

\begin{tabular}{|c|c|c|c|c|c|c|}
\hline \multirow{2}{*}{$\begin{array}{l}\text { Tratamento } \\
\text { (mM F/1. } \\
\text { de soluçäo }\end{array}$} & \multicolumn{2}{|c|}{$\mathbf{P}$} & \multicolumn{4}{|c|}{$\mathrm{N}$} \\
\hline & $\begin{array}{c}\text { P. aērea } \\
(\%)\end{array}$ & $\begin{array}{l}\text { Raiz } \\
(\%)\end{array}$ & $\begin{array}{c}\text { P. aérea } \\
(\%)\end{array}$ & $\begin{array}{l}\text { Raiz } \\
(\%)\end{array}$ & $\begin{array}{c}\text { Tota1 } \\
(\%)\end{array}$ & $\underset{(* * *)}{\mathrm{mg} / \mathrm{p} 1 \mathrm{anta}}$ \\
\hline \multicolumn{7}{|l|}{ CARIOCA } \\
\hline $\begin{array}{l}0,01 \\
0,05 \\
0,20 \\
0,25 \\
1,25\end{array}$ & $\begin{array}{l}0,227 \\
0,747 \\
0,655 \\
0,955 \\
1,087\end{array}$ & $\begin{array}{l}0,317 \\
0,697 \\
0,977 \\
1,197 \\
1,737\end{array}$ & $\begin{array}{l}2,842 \\
2,765 \\
2,530 \\
2,897 \\
2,927\end{array}$ & $\begin{array}{l}2,325 \\
2,320 \\
2,412 \\
2,042 \\
1,990\end{array}$ & $\begin{array}{l}2,710 \\
2,670 \\
2,505 \\
2,720 \\
2,732\end{array}$ & $\begin{array}{l}1,163 \\
1,126 \\
1,183 \\
1,200 \\
1,216\end{array}$ \\
\hline \multicolumn{7}{|l|}{ RICO - 23} \\
\hline $\begin{array}{l}0,01 \\
0,05 \\
0,20 \\
0,25 \\
1,25\end{array}$ & $\begin{array}{l}0,267 \\
0,745 \\
0,665 \\
0,960 \\
1,107\end{array}$ & $\begin{array}{l}0,272 \\
0,865 \\
1,067 \\
1,160 \\
1,685\end{array}$ & $\begin{array}{l}2,825 \\
2,927 \\
2,790 \\
2,732 \\
2,747\end{array}$ & $\begin{array}{l}1,927 \\
2,097 \\
1,962 \\
1,930 \\
2,067\end{array}$ & $\begin{array}{l}2,680 \\
2,695 \\
2,582 \\
2,525 \\
2,580\end{array}$ & $\begin{array}{l}1,242 \\
1,332 \\
1,230 \\
1,245 \\
1,258\end{array}$ \\
\hline \multicolumn{7}{|c|}{ VENEZUELA - 350} \\
\hline $\begin{array}{l}0,01 \\
0,05 \\
0,20 \\
0,25 \\
1,25\end{array}$ & $\begin{array}{l}0,215 \\
0,685 \\
0,602 \\
0,942 \\
1,122\end{array}$ & $\begin{array}{l}0,305 \\
0,650 \\
1,037 \\
1,120 \\
1,667\end{array}$ & $\begin{array}{l}2,902 \\
2,927 \\
2,797 \\
2,890 \\
2,742\end{array}$ & $\begin{array}{l}2,032 \\
2,085 \\
2,185 \\
2,025 \\
2,032\end{array}$ & $\begin{array}{l}2,687 \\
2,732 \\
2,667 \\
2,725 \\
2,590\end{array}$ & $\begin{array}{l}1,315 \\
1,392 \\
1,319 \\
1,298 \\
1,289\end{array}$ \\
\hline
\end{tabular}

OBS.: A legenda è a mesma da Tabela 6 


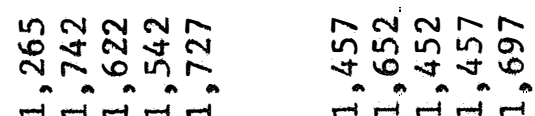

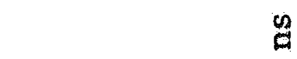

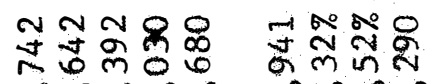

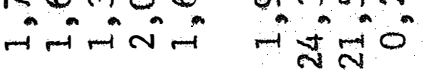

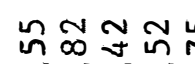

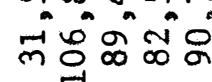

ํํㅇํㅇㅇำ

กำ 0 ค คํำ

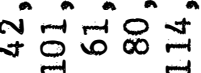

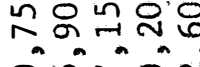
in $\infty$ i 윰

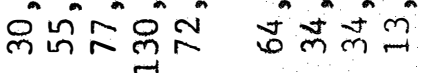

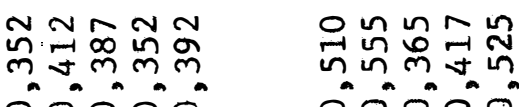

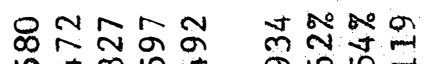

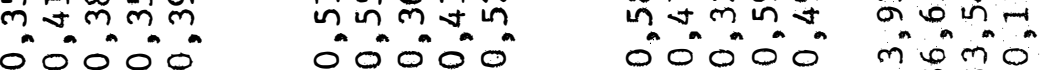
oñmin

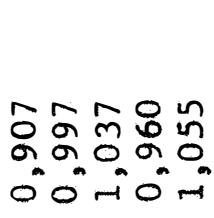
\&

$\sin$

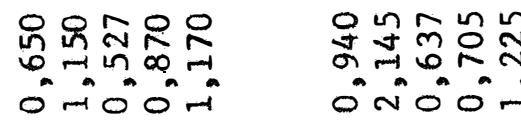

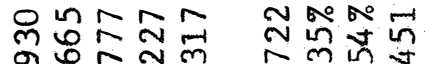

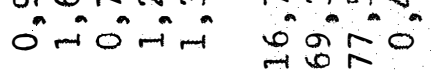

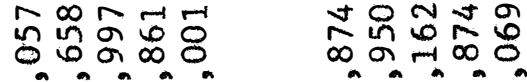

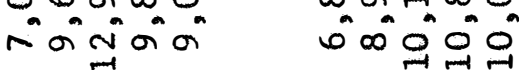

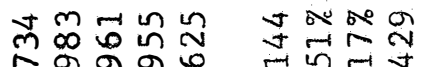
rag.

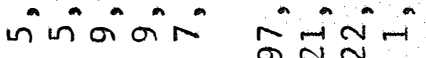

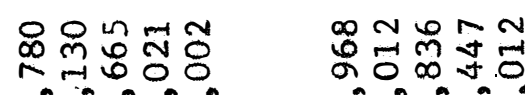

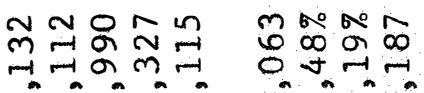

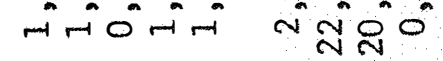
oniti-i 0 -ion-i-i

$m \mathfrak{m} m$ $\infty$ กิก अवत्रक मn

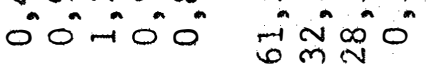

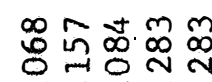
O00กั

ก

ㄷํㅇํำ ำก O०000ี

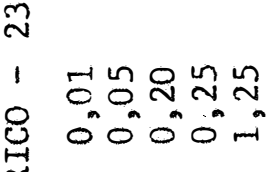

5

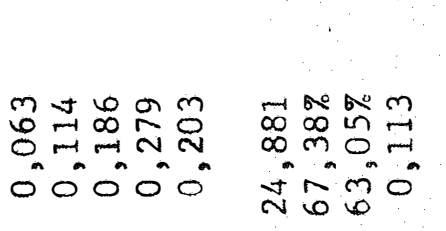
ㅇำ 
TABELA 13 - Continuação

\begin{tabular}{|c|c|c|c|c|c|c|}
\hline \multirow{2}{*}{$\begin{array}{l}\text { Tratamento } \\
\text { (mM P/I } \\
\text { de solução }\end{array}$} & \multicolumn{2}{|r|}{ p } & \multicolumn{4}{|c|}{$\mathrm{N}$} \\
\hline & $\begin{array}{c}\text { P. aérea } \\
(\%)\end{array}$ & $\begin{array}{l}\text { Raiz } \\
(\%)\end{array}$ & $\begin{array}{c}\text { P. aērea } \\
(\%)\end{array}$ & $\begin{array}{l}\text { Raiz } \\
(\%)\end{array}$ & $\begin{array}{c}\text { Total } \\
(\%)\end{array}$ & $\begin{array}{c}\mathrm{mg} / \mathrm{planta} \\
(* * *)\end{array}$ \\
\hline \multicolumn{7}{|l|}{ CARIOCA } \\
\hline $\begin{array}{l}0,01 \\
0,05 \\
0,20 \\
0,25 \\
1,25\end{array}$ & $\begin{array}{l}0,200 \\
0,407 \\
0,695 \\
0,485 \\
0,515\end{array}$ & $\begin{array}{l}0,165 \\
0,605 \\
1,125 \\
1,600 \\
2,655\end{array}$ & $\begin{array}{l}3,260 \\
2,727 \\
2,665 \\
2,620 \\
2,440\end{array}$ & $\begin{array}{l}2,467 \\
2,927 \\
1,780 \\
2,295 \\
2,522\end{array}$ & $\begin{array}{l}3,032 \\
2,802 \\
2,457 \\
2,542 \\
2,460\end{array}$ & $\begin{array}{l}1,580 \\
1,667 \\
1,576 \\
1,578 \\
1,611\end{array}$ \\
\hline \multicolumn{7}{|l|}{ RICO -23} \\
\hline $\begin{array}{l}0,01 \\
0,05 \\
0,20 \\
0,25 \\
1,25\end{array}$ & $\begin{array}{l}0,182 \\
0,375 \\
0,682 \\
0,472 \\
0,640\end{array}$ & $\begin{array}{l}0,150 \\
0,770 \\
1,690 \\
1,467 \\
2,692\end{array}$ & $\begin{array}{l}2,762 \\
2,627 \\
2,852 \\
2,557 \\
2,552\end{array}$ & $\begin{array}{l}2,235 \\
2,097 \\
1,897 \\
1,997 \\
2,015\end{array}$ & $\begin{array}{l}2,617 \\
2,400 \\
2,605 \\
2,382 \\
2,380\end{array}$ & $\begin{array}{l}1,561 \\
1,577 \\
1,572 \\
1,524 \\
1,581\end{array}$ \\
\hline \multicolumn{7}{|c|}{ VENEZUELA - 350} \\
\hline $\begin{array}{l}0,01 \\
0,05 \\
0,20 \\
0,25 \\
1,25\end{array}$ & $\begin{array}{l}0,167 \\
0,372 \\
0,592 \\
0,457 \\
0,502\end{array}$ & $\begin{array}{l}0,137 \\
0,772 \\
1,905 \\
1,600 \\
2,282\end{array}$ & $\begin{array}{l}2,772 \\
1,797 \\
2,980 \\
2,352 \\
2,325\end{array}$ & $\begin{array}{l}2,007 \\
2,310 \\
1,747 \\
2,155 \\
1,975\end{array}$ & $\begin{array}{l}2,512 \\
1,942 \\
2,610 \\
2,295 \\
2,212\end{array}$ & $\begin{array}{l}1,640 \\
1,494 \\
1,545 \\
1,648 \\
1,549\end{array}$ \\
\hline $\begin{array}{l}\text { F (1\%) } \\
\text { C.V. Res (a) } \\
\text { C.V. Res (b) } \\
\text { D.M.S. }\end{array}$ & $\begin{array}{r}1356,180 \\
8,64 \% \\
8,22 \% \\
0,044\end{array}$ & $\begin{array}{r}1495,140 \\
10,51 \% \\
12,41 \% \\
0,103\end{array}$ & $\begin{array}{r}73,112 \\
9,85 \% \\
8,76 \% \\
0,257\end{array}$ & $\begin{array}{r}13,100 \\
8,22 \% \\
9,09 \% \\
0,177\end{array}$ & $\begin{array}{r}78,845 \\
8,08 \% \\
7,56 \% \\
0,201\end{array}$ & $\begin{array}{l}3,417 \\
7,21 \% \\
6,08 \% \\
0,104\end{array}$ \\
\hline
\end{tabular}

OBS.: A legenda é a mesma da Tabela 6 


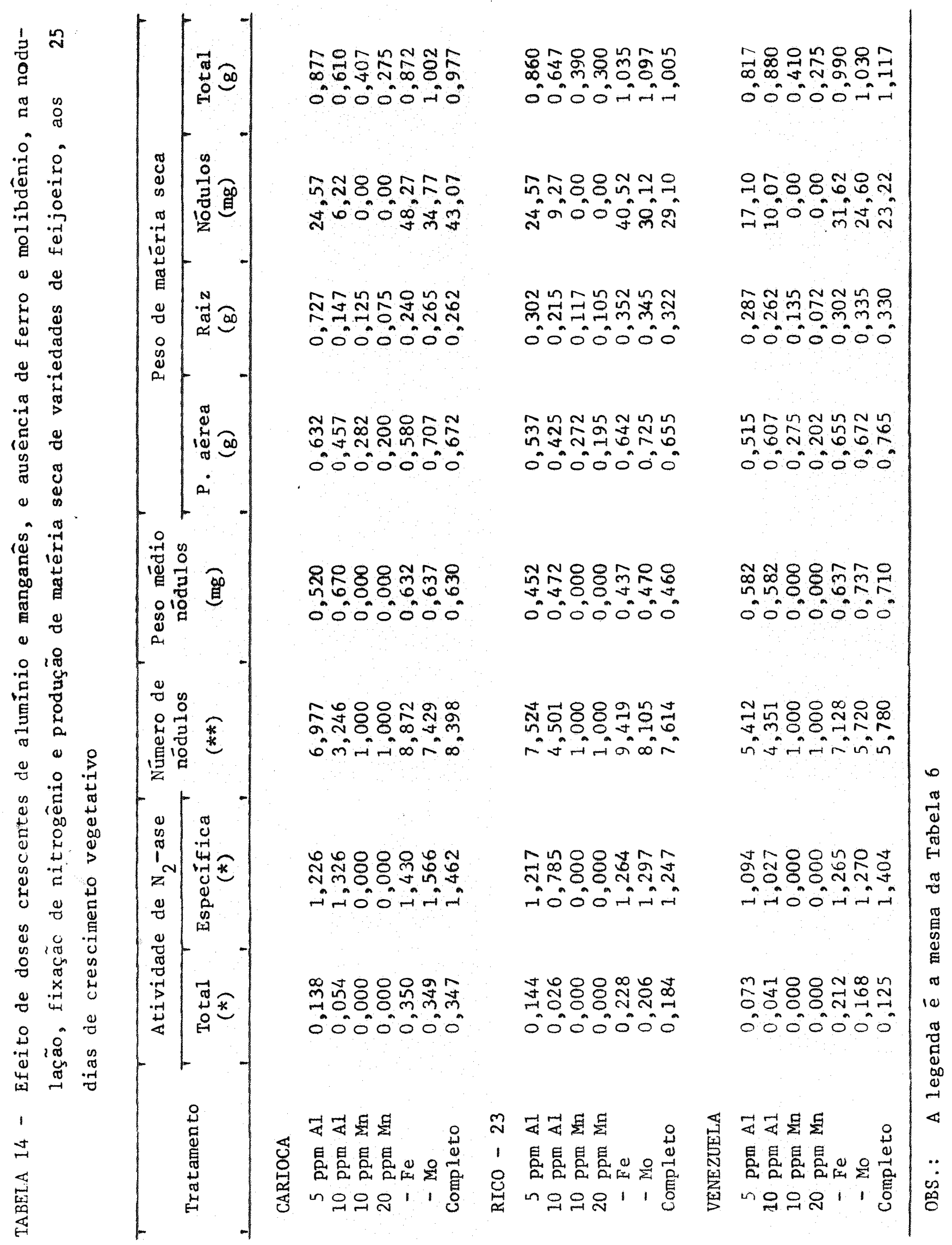




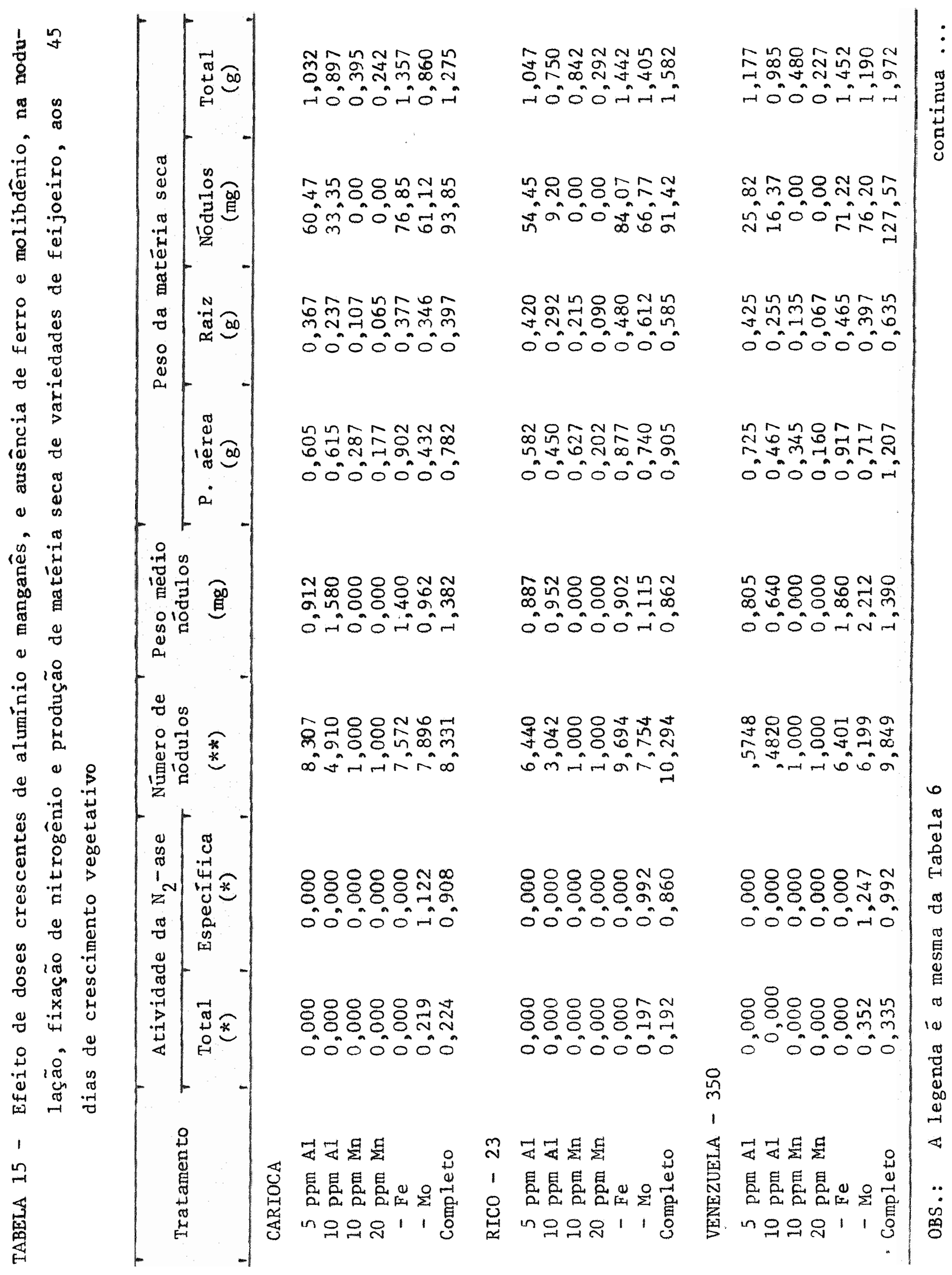


103.

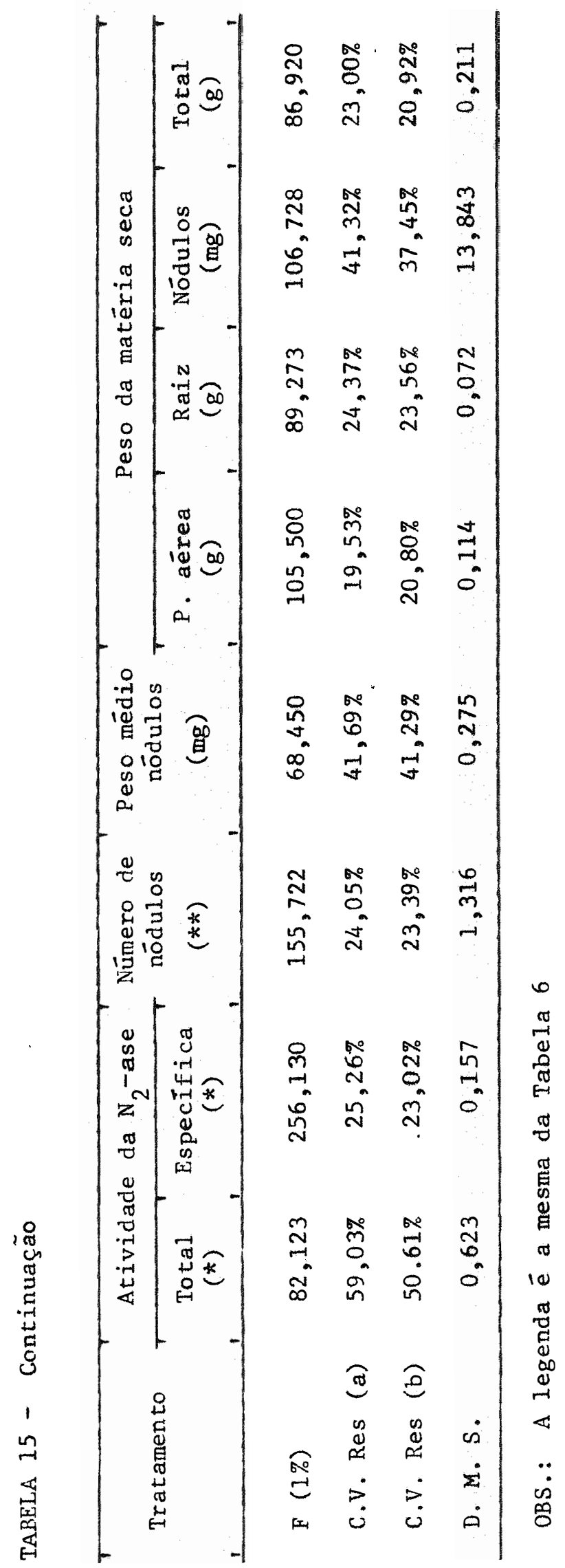




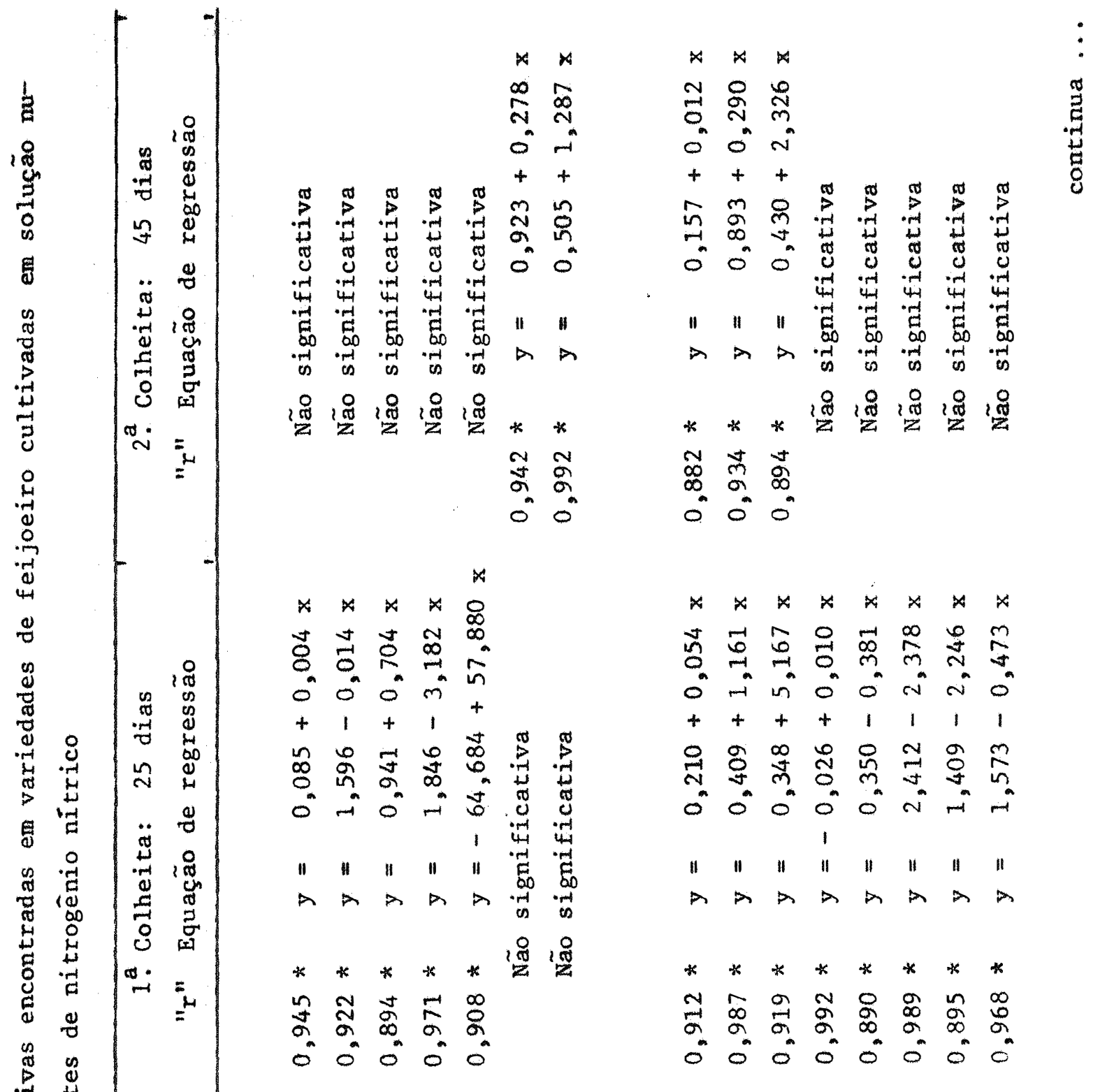

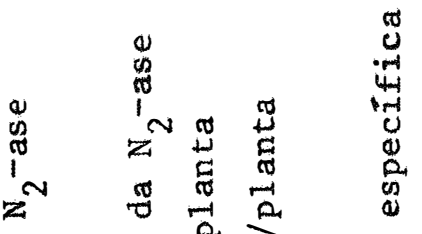

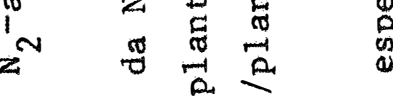

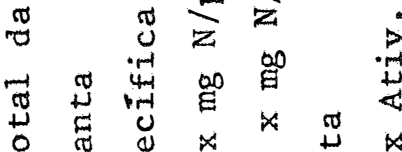

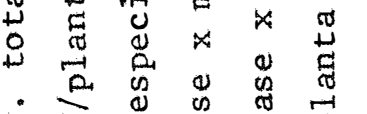

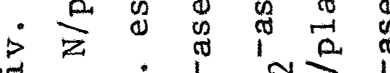

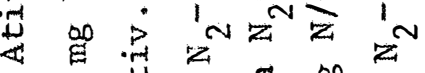

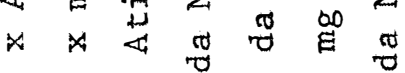

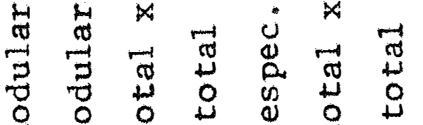

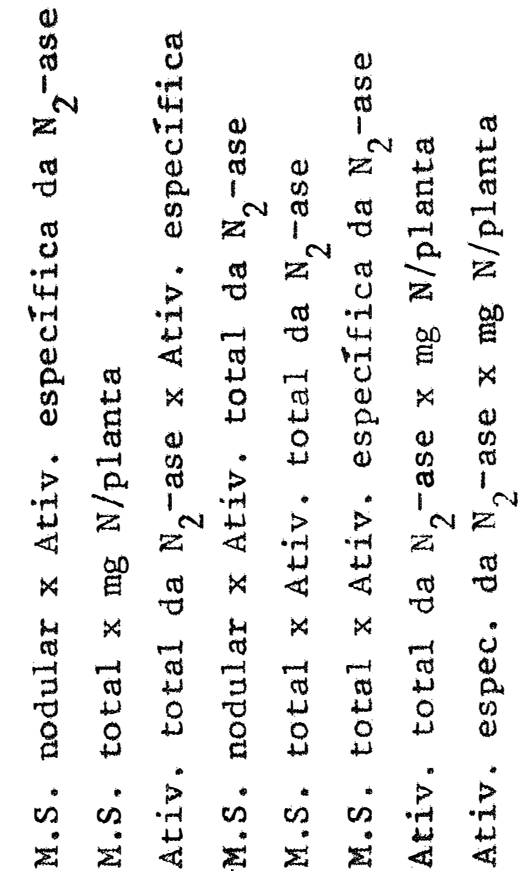




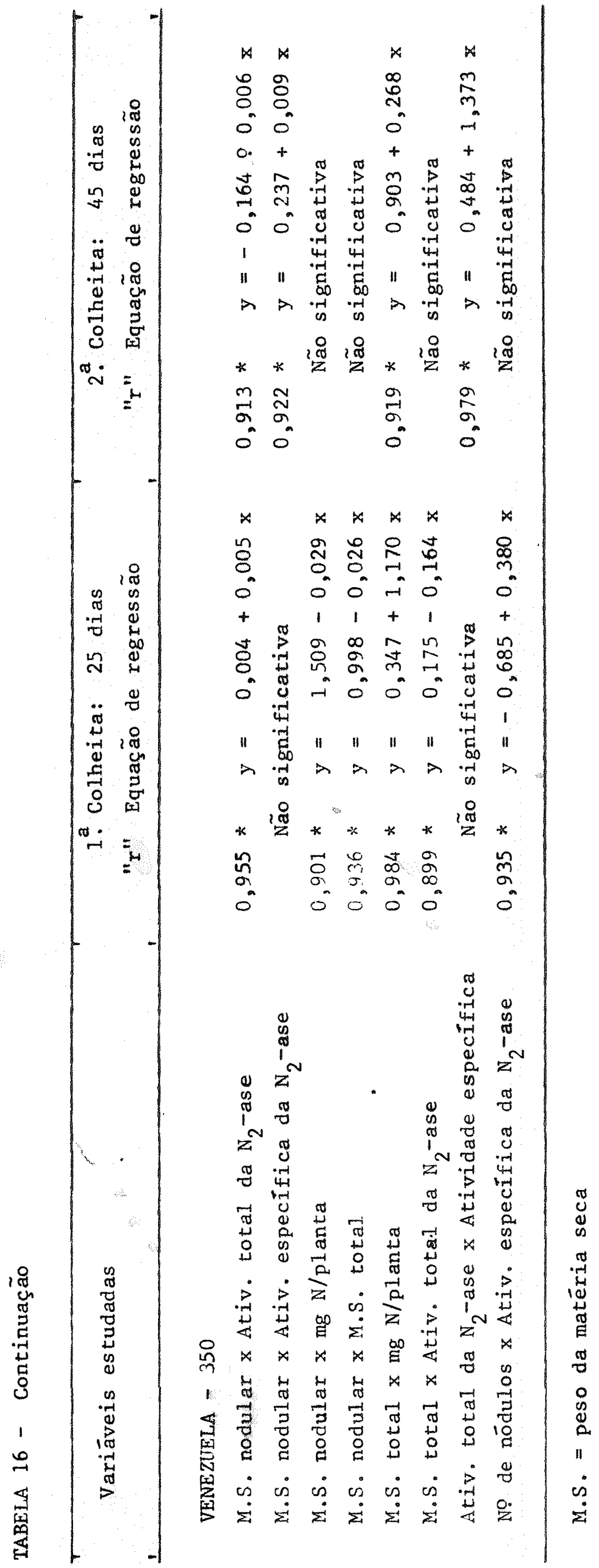




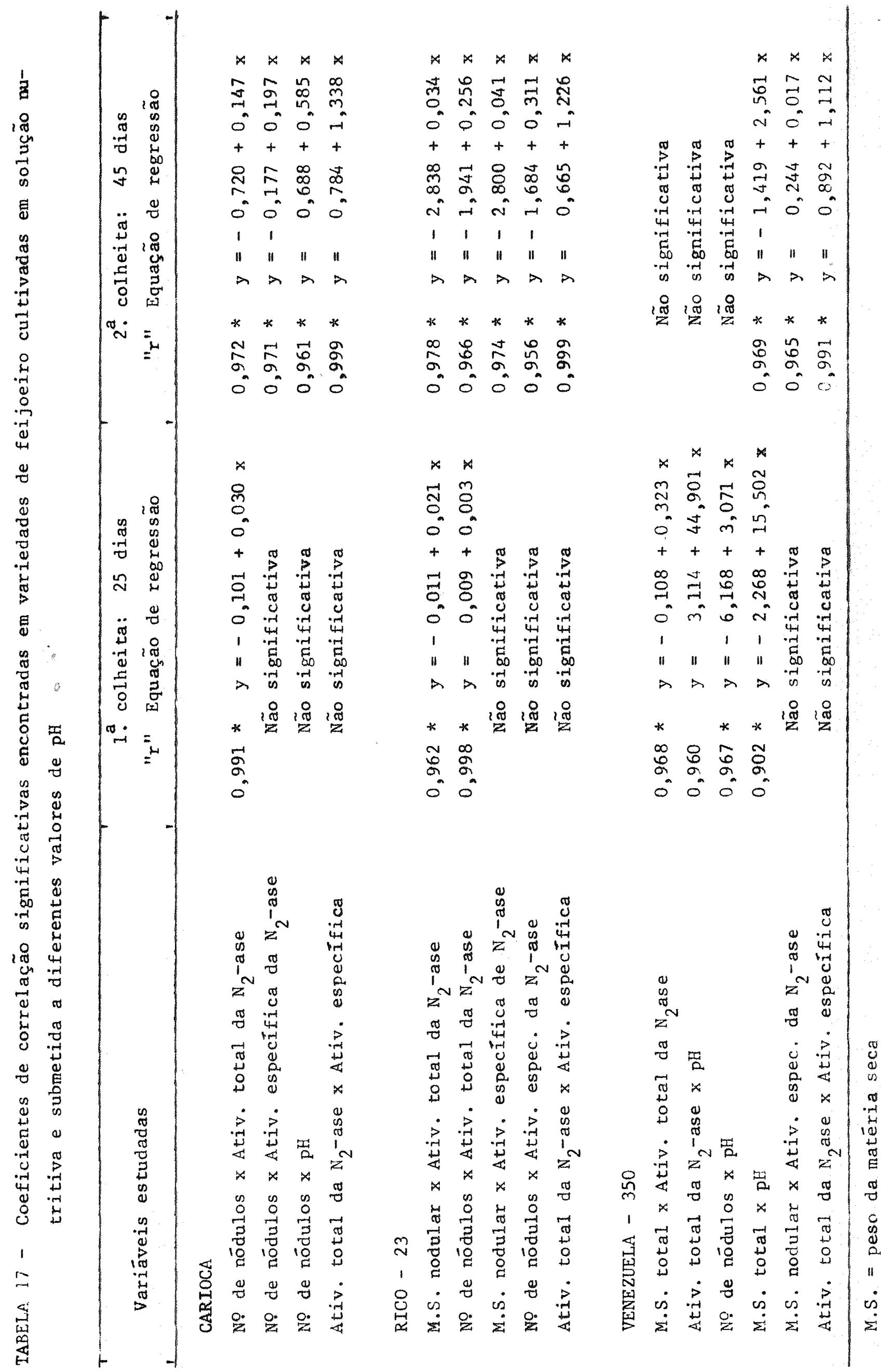




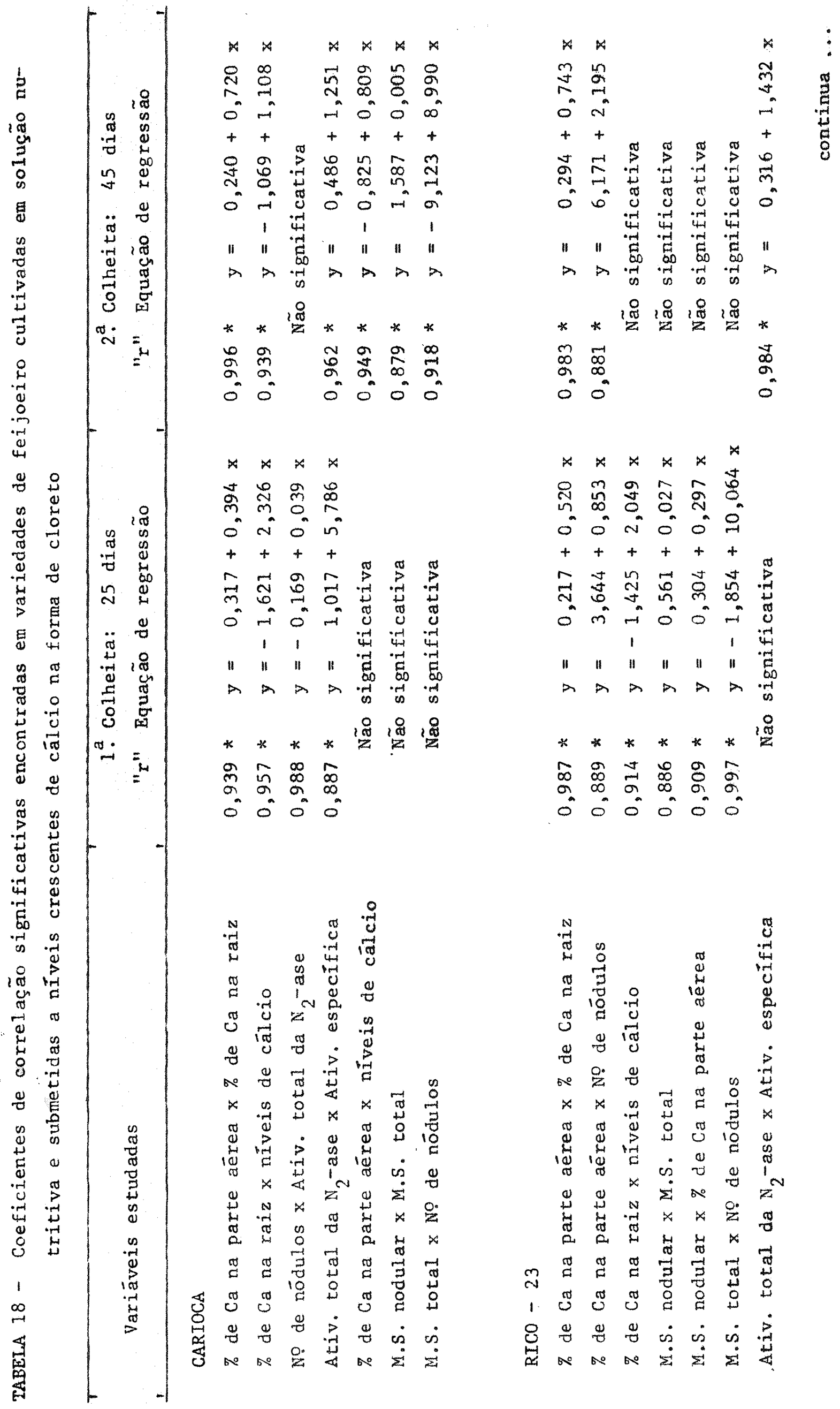




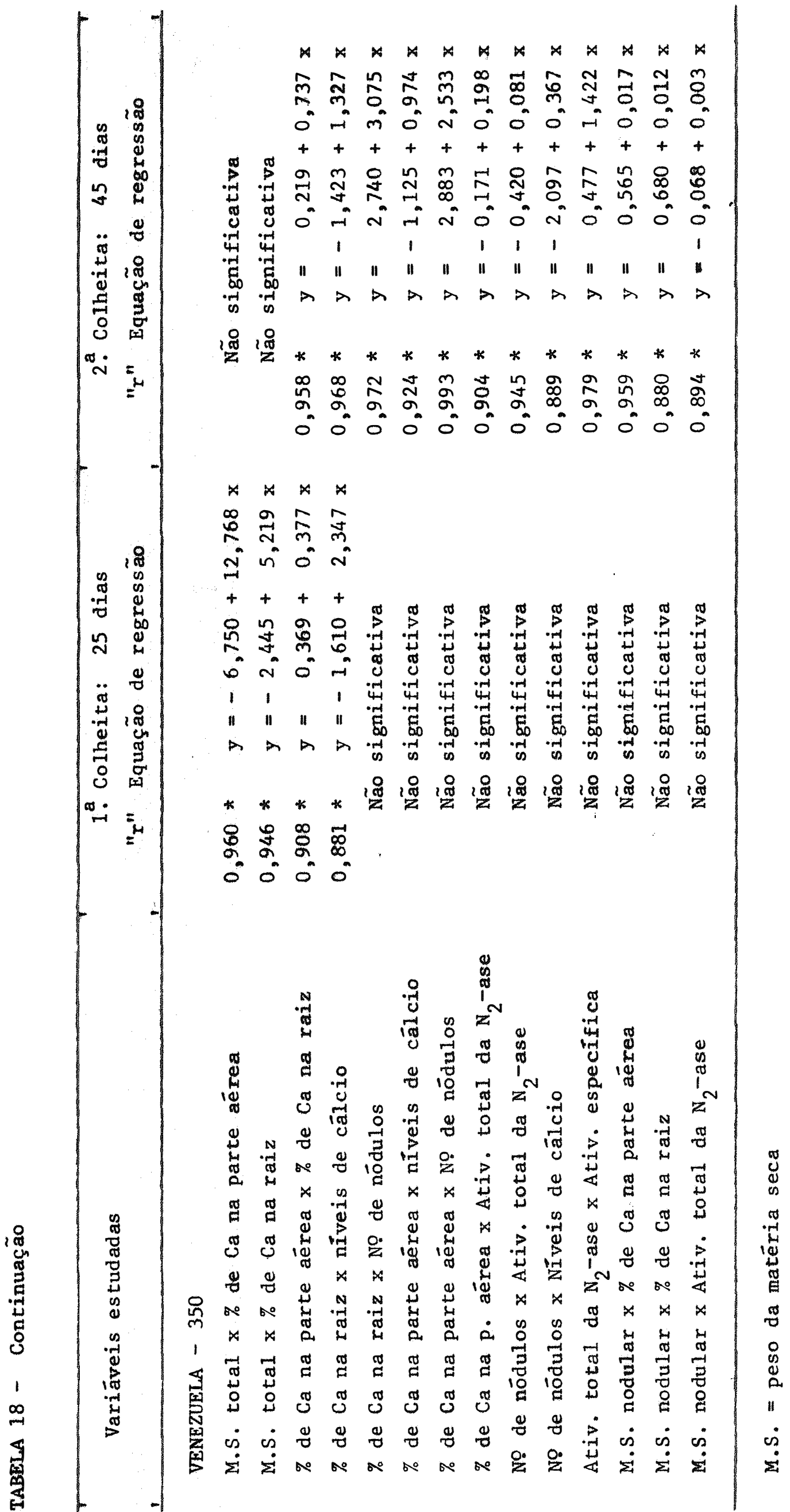




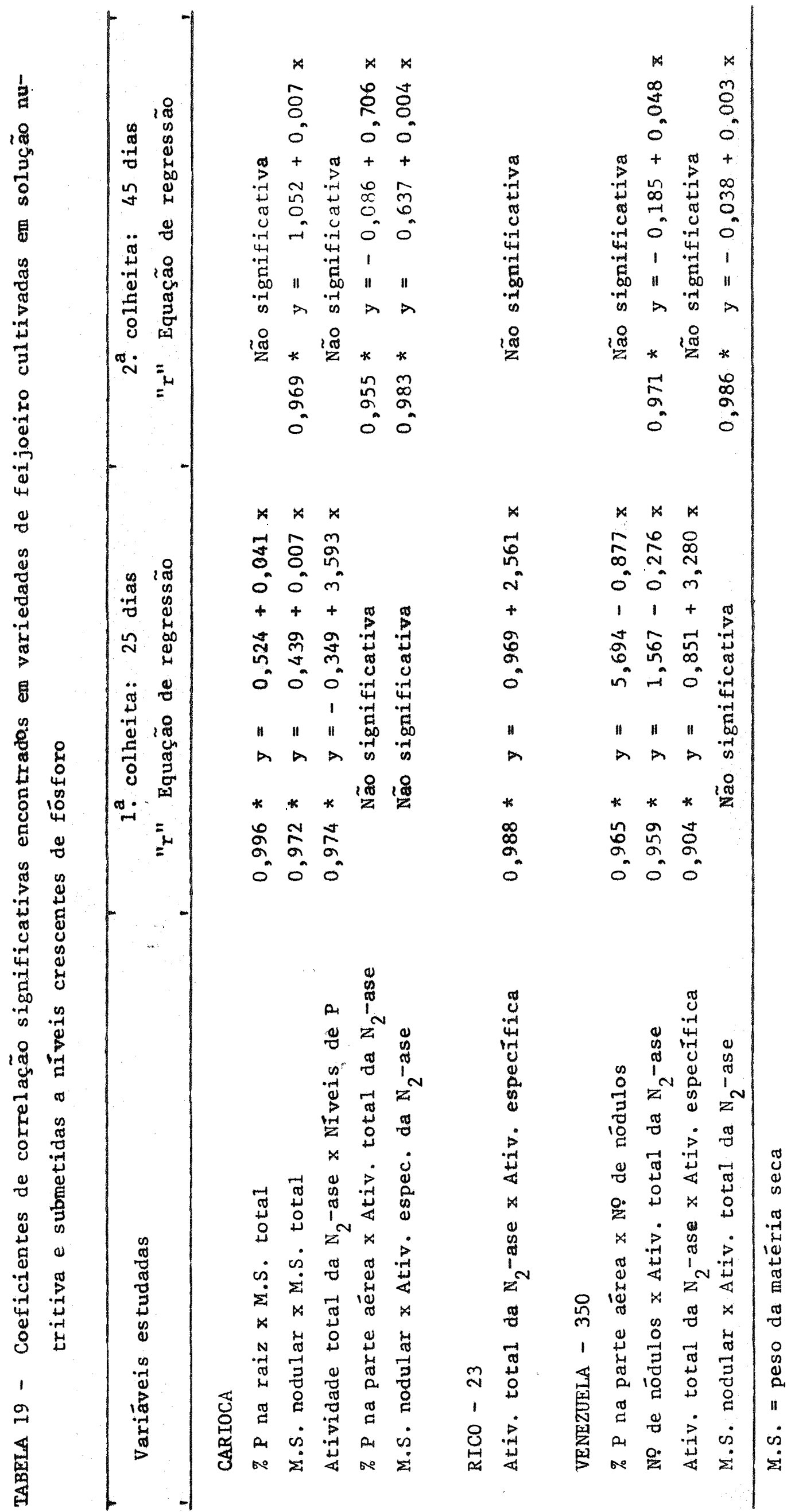




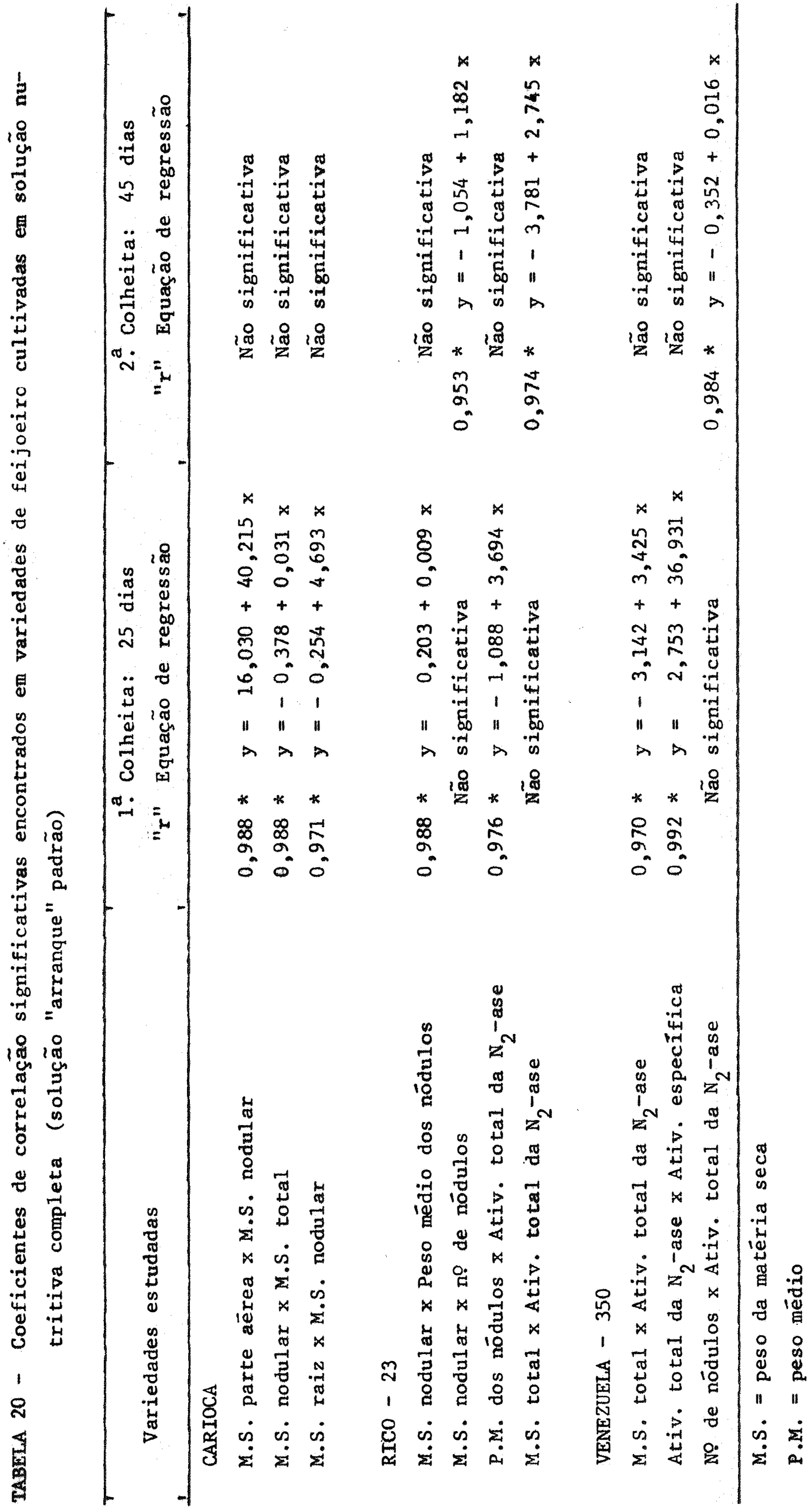




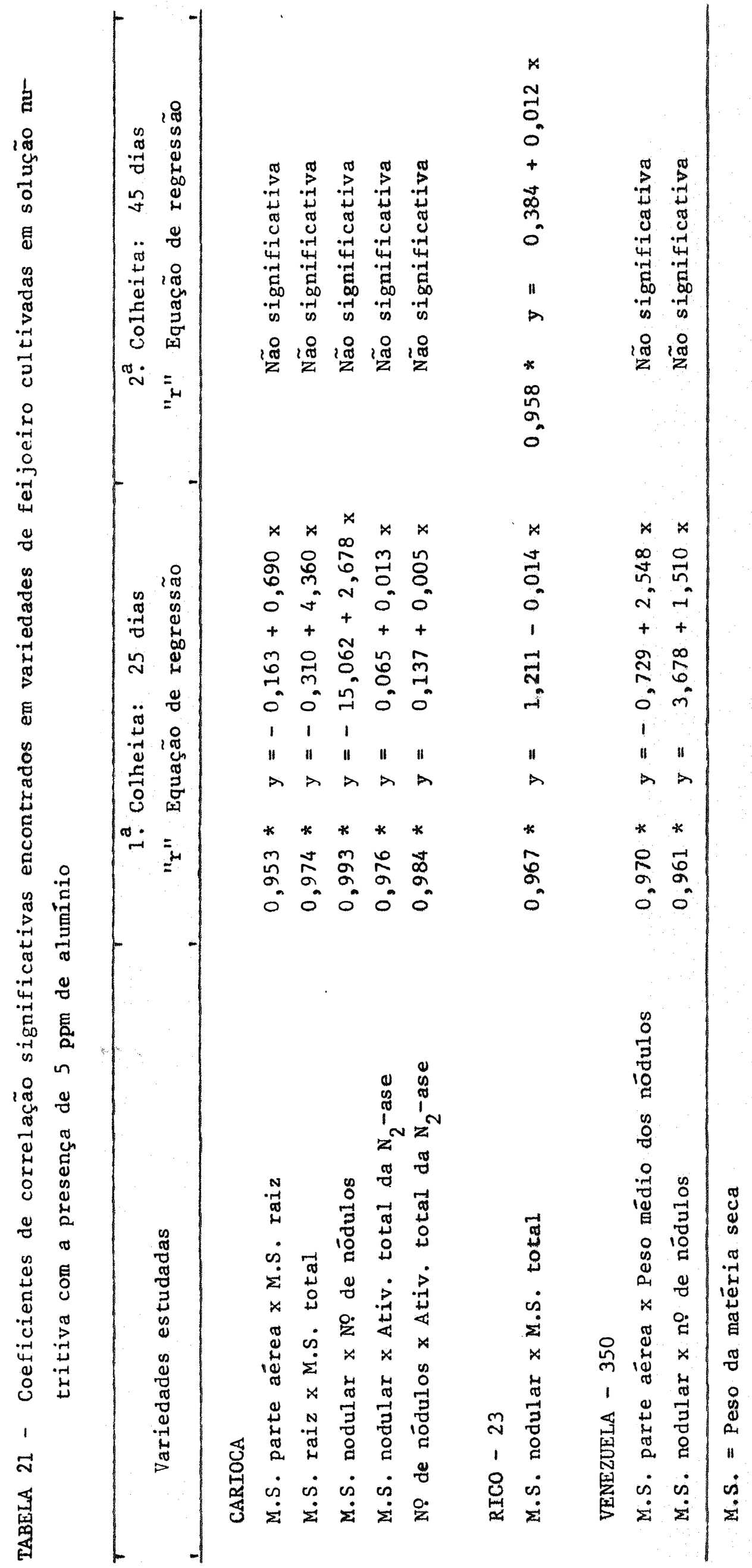


112.

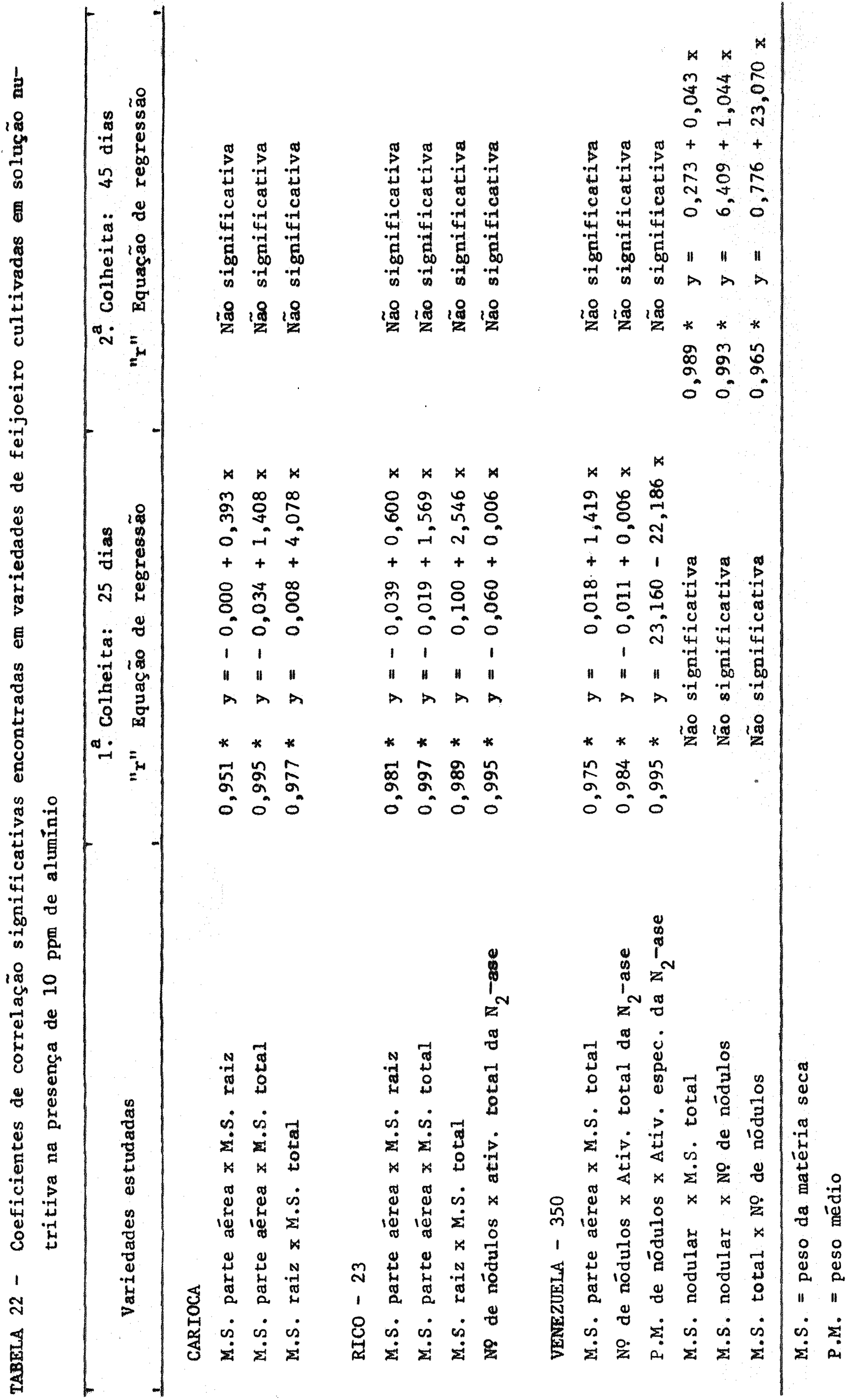


TABELA 23 - Coeficiente de correlação significativas encontrados em variedades de feijoeiro cultivadas em solução nutritiva com a presença de 10 ppm de manganês

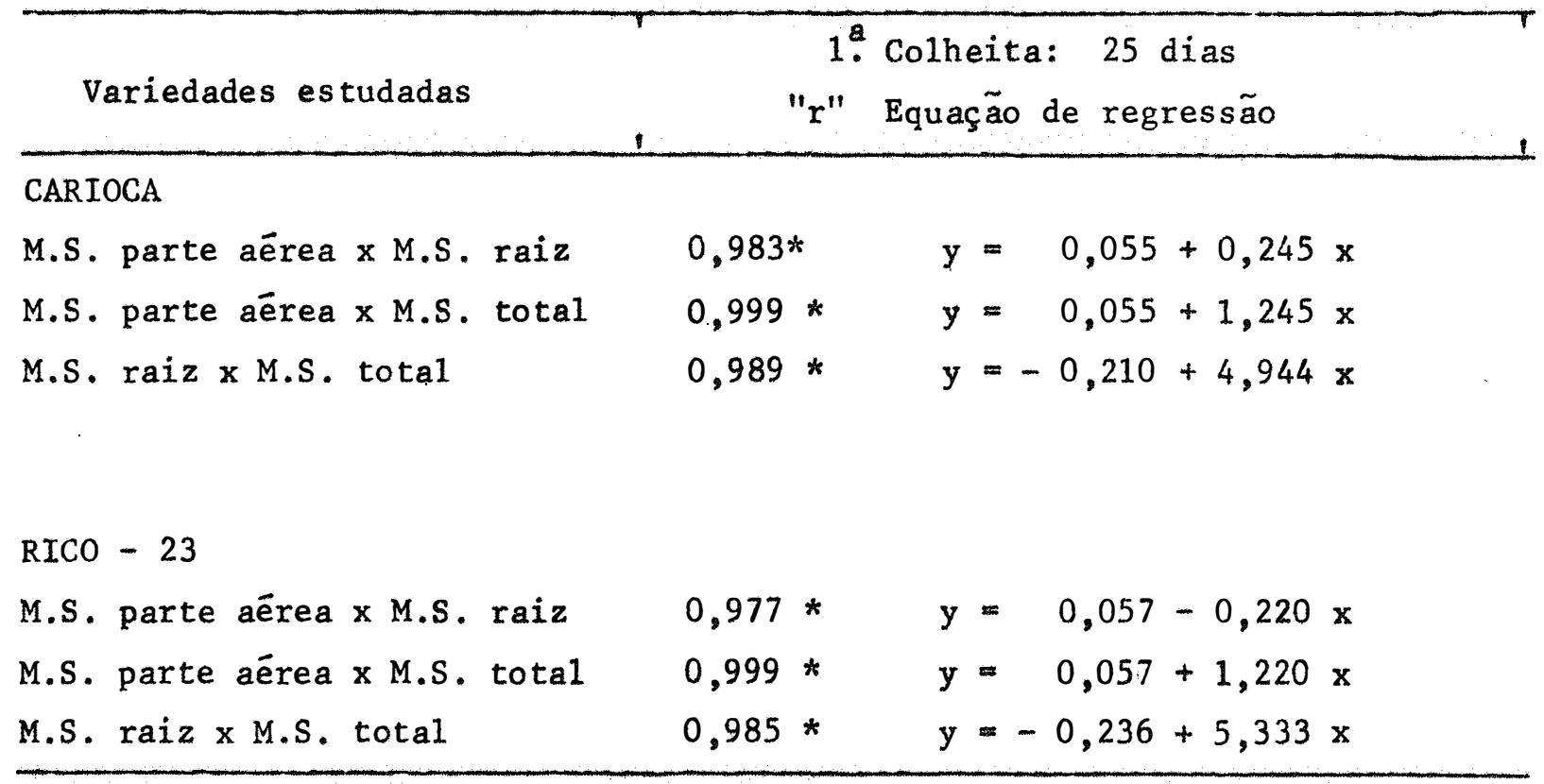

M.S. = peso da matéria seca

Obs.: As plantas não resistiram atē o 459 dia, quando se realizaria a 2. colheita. 
TABELA 24 - Coeficientes de correlação significativos encontrados em variedades de feijoeiro cultivadas em solução nutritiva com a presen ça de 20 ppm de manganês

\begin{tabular}{ll}
\hline Variäveis estudadas & 1 . Colheita: 25 dias \\
& "r" Equação de regressão \\
\hline
\end{tabular}

\section{CARIOCA}

M.S. parte aérea x M.S. total

$$
0,991 * \quad y=-0,001+1,380 x
$$

RICO - 23

M.S. parte aérea $\times$ M.S. total

$$
0,956 * \quad y=-0,012+1,600 x
$$

\begin{tabular}{|c|c|c|}
\hline M.S. parte aérea x M.S. total & $0,999 *$ & $y=-0,000+1,359 x$ \\
\hline M.S. parte aérea x M.S. raiz & $0,997 *$ & $y=-0,000+0,359 x$ \\
\hline M.S. raiz x M.S. total & $0,998 *$ & $0,001+3,767$ \\
\hline
\end{tabular}

M.S. = peso da matêria seca

Obs.: As plantas não resistiram até o 450 dia, quando se realizaria a 2. colheita. 


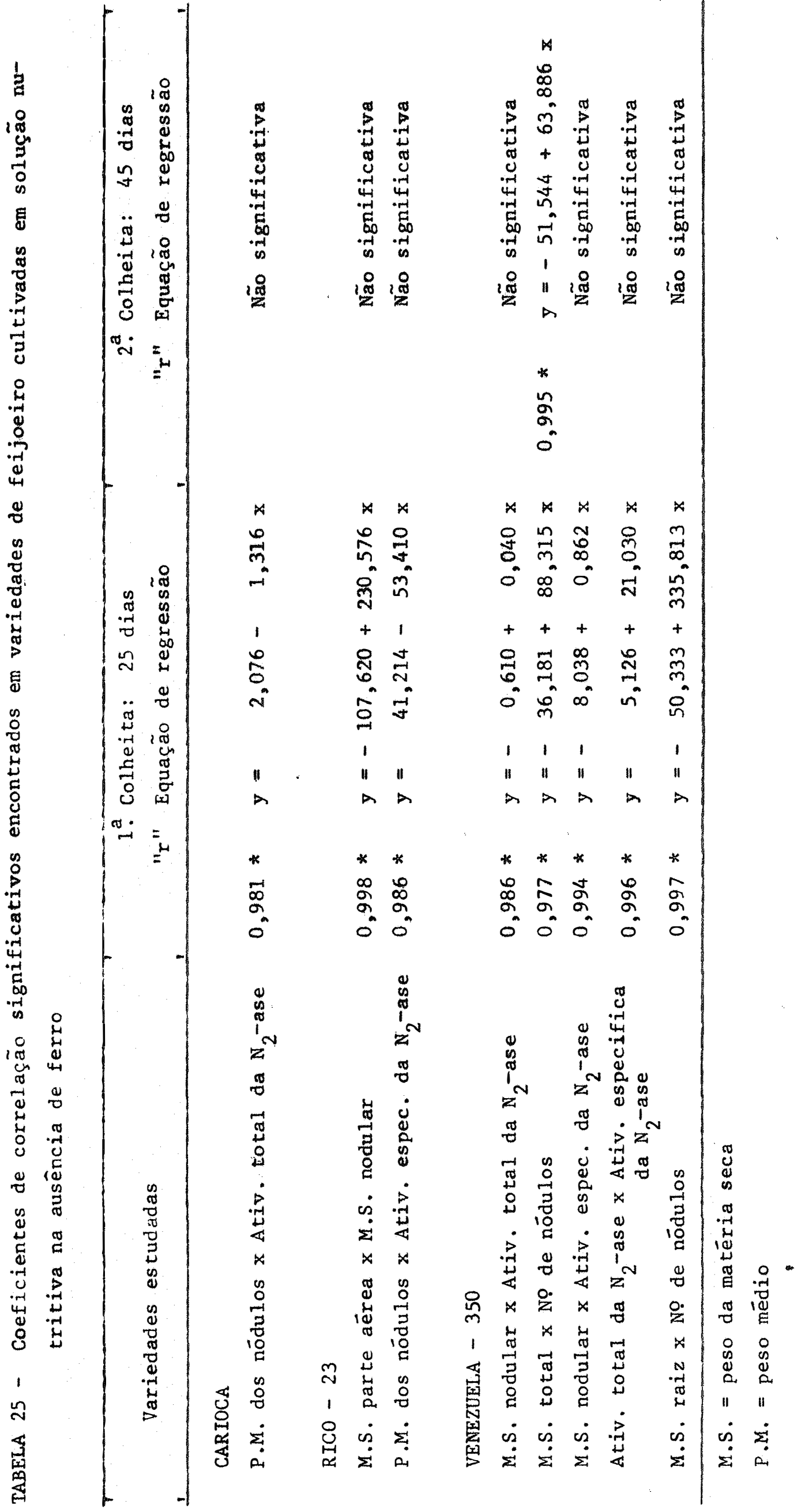




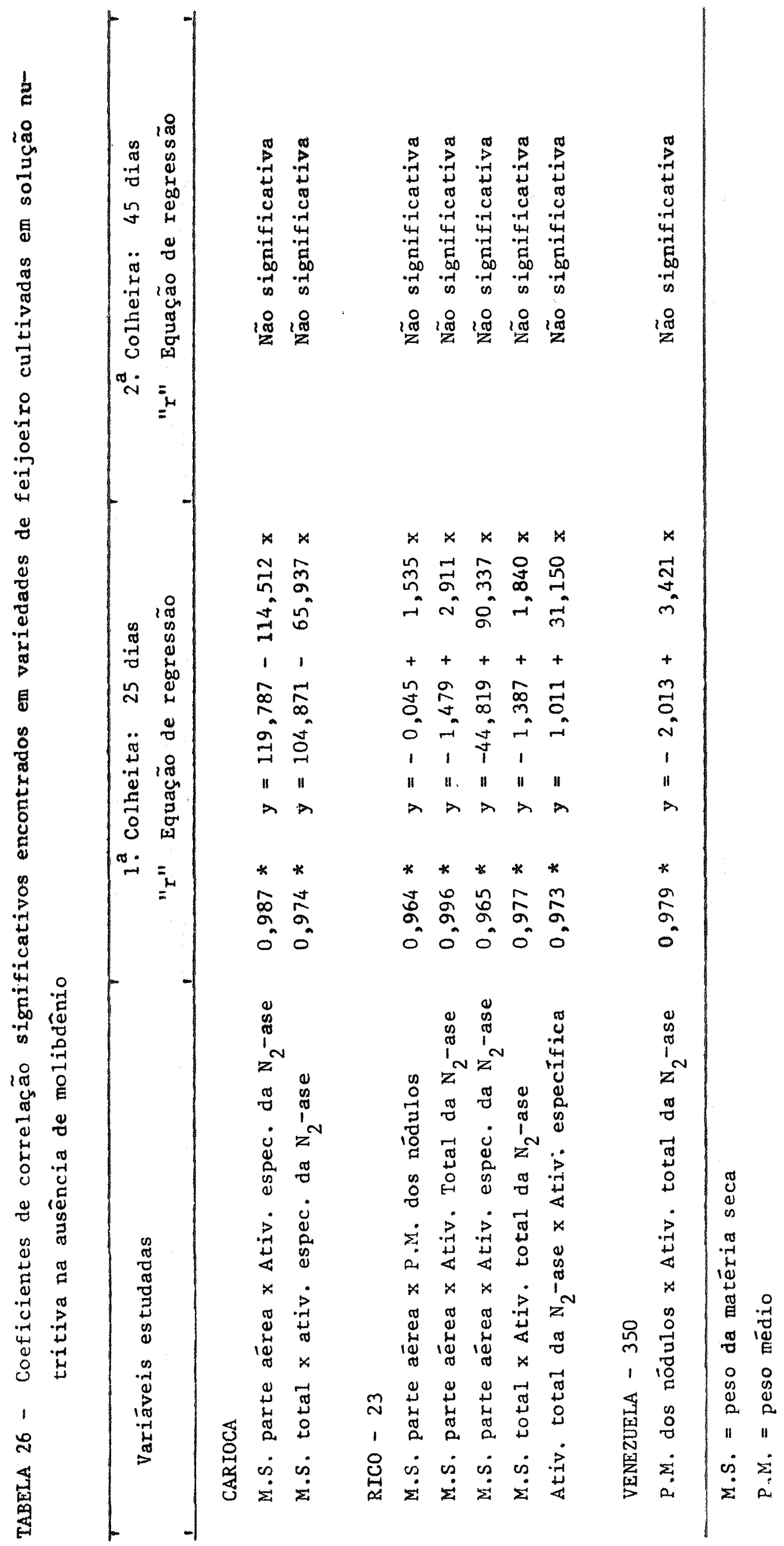


5 - CONCLUSOES

A luz dos resultados obtidos no presente trabalho através dos diferentes experimentos, e após submetê-los à analise estatística, pode-se tirar as seguintes conclusões:

a) - Diferenças entre as variedades de feijoeiro (Phaseolus vulgaris L.) estudadas, respectivamente, Carioca, Rico 23 e Ve nuela 350 , foram frequentes em ambas as idades de colheita (25 e 45 dias), sendo que, invariavelmente, o estádio vegetativo influenciou o peso da matéria seca, a nodulação e a fixação de nitrogênio; 
b) - As doses crescentes de nitrogênio sob a forma de nitrato (0 a 3,0 mM/1) administradas ao feijoeiro, afetaram a nodulação e a atividade total da $\mathrm{N}_{2}$-ase, reduzindo-as, mas a atividade específica da $\mathrm{N}_{2}$-ase, o peso da matéria seca e a quan tidade de $N$ absorvido, elevaram-se aos 25 dias de crescimen to vegetativo;

c) - Aos 45 dias de crescimento vegetativo, a nodulação número de nódulos e peso da matéria seca) aumentou até a dose de $1,2 \mathrm{mM}$ de $\mathrm{N}-\mathrm{NO}_{3}^{-}(16,8 \mathrm{ppm})$, para cair bruscamente com 3,0 $\mathrm{mM}$ de $\mathrm{N}^{-\mathrm{NO}_{3}^{-}}(42 \mathrm{ppm})$. A atividade da nitrogenase, tanto. total como específica, apresentou valores maiores com 0,3 mM de $\mathrm{N}^{-\mathrm{NO}_{3}^{-}}$, ao passo que o peso da matéria seca (parte aé rea, raiz e total) e o nitrogênio total absorvido responderam linearmente às doses crescentes de nitrogênio. Em ambas as idades, foi confirmada a necessidade de "dose de arranque" de $N$, necessária ao desenvolvimento inicial da plan ta, muito embora os níveis de tais exigências tenham diferi do entre as variedades;

d) - Todas as variedades estudadas foram drasticamente afetadas pelo $\mathrm{pH}$, e as melhores respostas com relação ao peso da matéria seca, nodulação e fixação de $N$, foram obtidas à medida que $O \mathrm{pH}$ alcançou os limites da neutralidade $(\mathrm{pH}=7,0)$, em ambos os estádios vegetativos. Entretanto, aos 45 dias de idade, todas as três variedades apresentaram os maiores valores para a atividade da nitrogenase, tanto total como específica, com o $\mathrm{pH} 6,0$; 
e) - Doses elevadas de Ca, 2,5 mM (100 ppm) beneficiaram a nodulação e a fixação de nitrogênio, avaliada através da ativi dade da nitrogenase, somente na variedade Venezuela 350 com 45 dias de idade, não se registrando tal tendência com rela ção ao $N$ absorvido. Considerando-se que o peso da matéria seca, total e nodular, são expressivos índices de avaliação da fixação de $N$, admite-se que $1,5 \mathrm{mM}(50 \mathrm{ppm})$, nas condifões experimentais do presente trabalho, pode ser considera da a dose ideal. A solução salina não afetou as variāveis estudadas, devido à baixa dose empregada. Os teores de Ca na parte aérea e na raiz elevaram-se como aumento das doses de $N$, não sendo acompanhada tal tendência com o $N$ absor vido pela planta;

f) - As variedades estudadas não responderam linearmente às doses de fósforo estudadas $(0,01$ a $1,25 \mathrm{~mm} / 1)$ e apresentaram um comportamento bastante diferente nas duas idades de cres cimento vegetativo. Aos 25 dias de idade, tanto a nodulação, como o peso da M.S. e a atividade da nitrogenase, apre sentaram valores mais elevados com doses mais altas $(0,25$ e $1,25 \mathrm{mM})$, confirmando-se a importância deste elemento no de senvolvimento inicial da planta, nem sempre beneficiando a nodulação ou a fixação do Nitrogênio. Em ambas as idades os teores de $P$ na parte aérea e na raiz elevaram-se com as coses de $P$, mas somente a raiz apresentou uma maior tendência à linearidade; 
8) - Nas doses estudadas, todas as variedades foram afetadas pela presença do Al e do Mn, principalmente com relação ao sís tema radicular, o que comprometeu o peso da M.S., a nodulação e a fixação de nitrogênio.

h) - As reservas de Mo existentes nas sementes do feijoeiro, são suficientes para assegurar o pleno desenvolvimento da planta, a nodulação e à fixação do nitrogênio;

i) - Devido às injūrias sofridas pelas plantas submetidas ao tra.. tamento menos Fe, nenhuma conclusão pode ser tirada do refe rido ensaio;

j) - o peso da M.S. nodular e o peso da M.S. total podem ser con siderados como valiosos índices de avaliação da fixação de nitrogênio pelo feijoeiro;

k) - A fixação do nitrogênio acompanhou sempre o desenvolvimento da planta, o que sugere a necessidade de novos estudos em estádios vegetativos mais avançados afim de que sejam avaliados os limites da atividade da nitrogenase, os quais representarão um parâmetro importante na avaliação da potencialidade de fixação de nitrogênio pelo feijoeiro.

1) - os vários fatores aqui estudados em solução nutritiva, sob condições controladas, demonstram a necessidade de se prosseguir em tais estudos, como meta prioritária, antecedendo 
outras hipóteses de trabalho em ensaios de campo, e envolven variedades conhecidas e de boa aceitação comercial.

m) - Os dados obtidos sugerem que nas condições de campo a baixa fixação de nitrogênio molecular pelo feijoeiro, traduzida nas respostas à adição desse elemento como adubo, podem se explicar pelo menos em parte devido à ação e interação de diversos fatores a saber: baixa concentração de $N$ combinado, insuficiente para o "arranque", acidez excessiva e baixos níveis de cálcio e fósforo, altos teores de Al e Mn. 


\section{6 - RESUMO}

Três variedades de feijoeiro (Phaseolus vulgaris L.), Carioca, Rico 23 e Venezuela $350^{\circ}$, foram cultivadas em solução nutritiva em experimentos conduzidos em casa de vegetação, sob con dições controladas e duas idades de colheita, aos 25 e 45 dias de crescimento vegetativo. Foram realizados cinco ensaios, atra vés dos quais estudou-se o efeito da presença de níveis crescentes de $\mathrm{N}^{-\mathrm{NO}_{3}^{-}}$combinado $(0 ; 0,3 ; 0,6 ; 1,2$ e $3,0 \mathrm{mM} / 1$ de solução), o efeito do $\mathrm{pH}(4,0 ; 5,0 ; 6,0$ e 7,0$)$, o efeito de níveis crescentes de Cálcio $(0,01 ; 0,05 ; 0,25 ; 0,50 ; 1,25$ e 2,50 $\mathrm{mM} / 1$ de solução), o efeito da presença de solução salina $(5,0 \mathrm{mM}$ de $\mathrm{NaC}(1)$, o efeito de níveis crescentes de Fósforo $(0,01 ; 0,5$; 0,$20 ; 0,25$ e $1,25 \mathrm{mM} / 1$ de solução) a toxidez do Al (5 e 10 ppm) e do Mn (10 e 20 ppm) e as ausências do Ferro e Molibdênio. 
Estimativas de produção foram feitas através do peso da Matéria Seca (M.S.) da parte aérea, da raiz, dos nódulos e M.S. total. A nodulação foi avaliada através do número de nódulos e do peso médio dos nódulos. A fixação do $N$ foi determinada atravēs da atividade da nitrogenase avalia-se pelo método de redução do acetileno e, pelas determinações dos teores de $N$ na raiz e parte aérea, além da quantidade total de $N$ absorvido (mg/planta). Nos ensaios de $\mathrm{Ca} \mathrm{e}^{\prime} \mathrm{P}$, procedeu-se à determinação dos teores dos referidos elementos na parte aérea e na raiz.

Em todos os ensaios, a anälise de variância detectou dife renças significativas entre Tratamentos, entre Variedades e entre Idade de colheita, para a quase totalidade das variáveis estudadas. Doses elevadas de $\mathrm{N}-\mathrm{NO}_{3}^{-}(3,0 \mathrm{mM})$ inibiram a nodulação e a fixação de $N$, mas aumentaram o peso da M.S. total e a quanti dade de $\mathrm{N}$ absorvido, enquanto doses de "arranque" $(0,3$ a $1,2 \mathrm{mM})$ aumentaram a nodulação e a fixação de N. Todas as variedades es tudadas apresentaram uma tendência à melhor comportamento nos va lores de $\mathrm{pH} 6,0$ e 7,0 ao passo que o $\mathrm{pH}$ 4,0 reduziu drasticamente - peso da M.S., a nodulação e a fixação de N. Os resultados obtidos com os diferentes niveis de Ca estudados apresentaram uma tendência para se sugerir o melhor tratamento como sendo 1,25 mM/1itro (50 ppm), embora persistam diferenças entre Variedades, e para a interação Tratamentos x Variedades, em algumas varia veis estudadas.

Não houve resposta linear ao Fósforo, mas aos 25 dias de idade, as exigências foram maiores. Os teores de Ca e P, na par te aérea e na raiz, elevaram-se à medida que as concentrações 
dos referidos elementos aumentaram, mas a quantidade de $\mathrm{N}$ absorvido não acompanhou essa tendência.

Nas doses estudadas, tanto o Al ( 5 e 10 ppm) comoom (10 e $20 \mathrm{ppm}$ ), efetaram o desenvolvimento do sistema radicular, inibindo a nodulação, a fixação de $\mathrm{N}$ e a produção de matéria seca. As injürias sofridas pelas plantas em decorrência do ataque de ācaros, prejudicou o tratamento menos Fe, não permitindo que fosse tirada qualquer conclusão.

As reservas de Mo existentes nas sementes do feijoeiro, fo ram e mais possíveis contaminaçoes suficientes para o desenvolvi mento da planta, simbiose e fixação de nitrogênio. A presença da solução salina $(5,0 \mathrm{mM}$ de $\mathrm{NaCl})$ não afetou nenhuma das variáveis estudadas. 
Three bean varieties (Phaseolus vulgaris L.) were grown in nutrient solution during 2 periods, 25 and 45 days.

The effects of: combined $\mathrm{N}$ (as $\mathrm{NO}_{3}^{-}$at the levels of 0 , $0.3,0.6,1.2$ and $3.0 \mathrm{mM} / 1), \mathrm{pH}(4.0,5.0,6.0$ and 7.0$)$, Ca supply $(0.01,0.05,0.25,0.50,1.25$ and $2.50 \mathrm{mM} / 1)$, sa linity $(5.0 \mathrm{mM} \mathrm{NaCl}), P$ supply $(0.01,0.05,0.20,0.25$ and $1,25 \mathrm{mM} / 1)$, Al toxicity (5 and $10 \mathrm{ppm})$, Mn toxicity (10 and $20 \mathrm{ppm}$ ), and Fe and Mo deficiencies on growth of nodules, $\mathrm{N}_{2}-$ - fixation were studied and numeral composition ( $C a$ and $P$ experiments only) were studied.

The main conclusions were the following: 
Growth was promoted by increasing the level of combined $\mathbb{N}$; only the starter treatments $(0.3$ and $1.2 \mathrm{~mm} / 1)$ promoted no dulation and $\mathrm{N}_{2}$-fixation as determined by nitrogenase activity (acetylene reduction technique).

Higher dry matter production was observed at $\mathrm{pH} 6.0-7.0$ whereas at $\mathrm{pH} 4.0$ poor growth could be ascrebed to low $\mathrm{N}_{2}$-fixa tion.

A favourable Ca effect on the parameters under study was observed up to the level of $1.25 \mathrm{mM} / 1$.

A non linear response to $P$ supply was also verified.

Excess Al and Mn did cause inibition on nodulation, small root growth and $\mathrm{N}_{2}$-fixation.

No effect was observed in the minus Mo treatments.

Mite infestation in the minus Fe treatment did not allow for conclusions to be drawn.

Varietal differences were observed. 
ADAMS, M.W. 1973. Plant architecture and physiological efficien cy in the field bean: In: Potentials of field bean and other food legumes in Latin America. Cali, Colombia, CIAT, p. $266-278$.

ALMEIdA, D.L. ; G.G. PESSAnha e A.F. PEnteado. 1973. Efeito da calagem e da adubação fosfatada e nitrogenada na nodulação e produção do feijoeiro (Phaseolus vulgaris). Pesq. agropec. bras. 8: $127-130$.

AMARAL, F.A.L. 1975. Eficiência de utilização de nitrogênio, fós fosforo e potássio de 104 variedades de feijoeiro (Phaseol.us vulgaris, L.) ESALQ/USP, $11 \mathrm{p}$. (Tese de Doutoramento).

ANDREW, C.S. e D.O. NORRIS. 1961. Comparative responses to Ca1cium of five tropical and four temperate pasture legume species. Aust. J. agric. Res. 12:40-55. 
ANDREW, C.S. 1962. Influence of nutrition on nitrogen fixation and growth of legumes. In: Commonwealth Organization. Divi sion of Tropical Pastures. A review of nitrogen in the tropics. with particular reference to pastures; a symposium. Bu11. 46, Austra1ia, p. 130-146.

ANDREW, C.S. e M.P. HEGARTY. 1969. Comparative responses to man ganese excess. of eight tropical and four temperate pasture legume species. Aust. J. agric. Res. 20 (4):587-696.

ANDREW, C.S. e M.F. ROBINS. 1969a. The effect of Phosphorus on the growth and chemical composition of some tropical pasture legumes. I. Growth and critical percentages of phosphorus. Aust. I. agric. Res. 20: $665-674$.

ANDREW, C.S. e M.F. ROBINS 1969b. The effect of Phosphorus on the growth and chemical composition of some tropical pasture legumes. II. Nitrogen, Calcium, Magnesium, Potassium, and Sodium contents. Aust. J. agric. Res. 20: 675-685.

ANDREW, C.S. e P.J. VANDEN BERG. 1973. The influence of Aluminium on phosphate absorption by whole plants and excised roots of some pasture legumes. Aust. J. agric. Res. 24 (3): $341-351$.

ANDREW, C.S. 1976. Effect of Calcium, pH and Nitrogen on the growth and chemical composition of some tropical and tempera te pasture legumes. I. Nodulation and growth. Aust. J. agric. Res. 27 (5): 611-625.

ANDREW, C.S. e A.D. JOHNSON. 1976. Effect of Calcium, pH and Ni trogen on the growth and chemical composition of some tropical and temperate pasture legumes. II. Chemical Composition (Calcium, Nitrogen, Potassium, Magnesium, Sodium and Phospho rus. Aust. J. agric. Res. 27 (5): 626-637. 
ANDREW, C.S. 1977. Legumes and Acid Soils. In: Int. Symposium on the limitations and potentials of biological nitrogen fixation in the tropics. Brasilia, $26 \mathrm{p}$.

APPLEBY, C.A. 1974. Leghemoglobin. In: QUISPEL, A. The Biology of Nitrogen Fixation. North-Holland Publ. Comp., Amsterdam. p. 521-554.

AYOUB, A.T. 1974. Effect of calcium on sodium salinization of Beans. (Phaseolus vulgaris L.). J. Exp. Bot. 25 (85): 245-252.

BALASUBRAMANIAN, V. e S.K. SINHA. 1976. Effects of salt stress on growth, nodulation and nitrogen fixation in cowpea and. Mung Beans. Physio1 P1ant. 36 (2): 197-200.

BANATH, C.L. ; E.A.N. GREENWOOD e J.F. LONERAGAN. 1966. Effect of Calcium deficiency on symbiotic nitrogen fixation. Plant. Physio1. 41 (1): 760-763.

BEN-ZIONI, A. ; C. ITAI e Y. VAADIA. 1967. Water and salt stres sed, kinetin and protein synthesis in tobacco leaves. Plant. Physio1. 42: 361-365.

BERGERSEN, F.J. 1971. The central reactions of nitrogen fixation. P1ant Soil. Spec. Vol. 512-523.

BERGERSEN, F.J. 1973. Symbiotic Nitrogen fixation by Legumes. In: BUTLER, G.W. e R.W. BAILEY. Chemistry and Biochemistry. of Herbage. Vo1. 2. Academic Press, London New York. p 189226 .

BERNSTEIN, I. e G. OGATA. 1966. Effects of salinity on nodulation, nitrogen fixation and growth of soybeans and alfafa. Agronomy, J. 58: 201-203. 
BORGES, A.C.; I.R. JARDIM FREIRE e J.A. BRAGA. 1974. Experimen to sobre efeito da calagem, Molibdênio, Enxofre e Zinco sobre a nodulação e fixação do nitrogênio em soja. In: VIIa. Reunión Latinoamericana sobre Rhizobium, Resistência, Chaco, Argentina. Univ. Nac. del Nordest. p. 40-56.

BOULTER, D. 1977. Breeding for proteins in Legumes. In: Curso Intensivo de Proteínas Vegetais. CNEM/USP/ESALQ. Piracicaba, $46 \mathrm{p}$.

BRASIL. Fundação Instituto Brasileiro de Geografia e Estatística. 1970. Anuário Estatístico do Brasil.

BRASIL. Fundação Instituto Brasileiro de Geografia e Estatística. 1976. Anuārio Estatístico do Brasil.

BRAY, R.H. 1954. A nutrient mobility condept of soil-plant relationships. Soil sci. $78: 9-22$.

BREMNER, J.M. 1965. Total Nitrogen. In: Methods of soil analy sis. Part 2. BLACK, C.A. (Ed.) Am. Soc. of Agron. Inc. Pub1. Mad. Wis. USA.

BRESSANI, R. ; M. FLORES e L.G. ELIAS. 1973. Accetability and value of food legumes in the human diet. In: Potentials of field beans and other food legumes in Latin America. Proced., Cali, Colombia, CIAT. p. 26-63.

BRILL, W.J. 1977. Biological Nitrogen fixation. Sc. Amer. 236 (1) : $68-81$.

BUTLER, G.W. e D.I.H. JONES. 1973. Mineral Biochemistry of Herbage. In: BUTLER, G.W. e R.W. BAILEY. Chemistry and Biochemistry of Herbage. Vo1. 2. Academic Press, London, New York. p. $127-162$. 
CABEDA, M. e J.R. JARDIM FREIRE. 1968. Informe preliminar sobre a toxidez de manganês e alumínio sobre a nodulação e fixação simbiótica de nitrogênio em soja em solos äcidos do Rio Grande do Sul. In: Anais da IV Reunião Latinoamericana sobre inoculantes para Leguminosas, Porto Alegre, p. 282-294.

CARTWRIGHT, P.M. e D. SNOW. 1962. The influence of foliar aplii cations of urea on the nodulation pattern of certain leguminous species. Annals Botany. 26 (102): 251-259.

CARTWRIGHT, P.M. 1967. The effect of combined Nitrogen on the growth and nodulation of excised roots of Phaseolus vulgaris L. Annals Botany, 31 (122): 309-321.

CHAGAS, J.M. e C. VIEIRA. 1975. Efeitos de intervalos de plantio e de níveis de adubação sobre o rendimento e seus componentes, em algumas variedades de feijão (Phaseolus vulgaris L. Annals Botany, 31 (122): 309-321.

CIAT, 1975. Centro Internacional de Agricultura Tropical. Progra ma de sistemas de producción de frijol (Phaseolus vulgaris L.) Cali, Colombia, Série FS-5, 40 p.

COBRA NETO, A. 1967. Absorção e deficiências dos macronutrientes pelo feijoeiro (Phaseolus vulgaris L. var. Roxinho). Piracicaba. ESALQ/USP. 67 p. (Tese de Doutoramento).

COLE, C.V. ; D.L. GRUNES; L.K. PORTER e S.R. OLSEN. 1963. The effects of Nitrogen on short-term phosphorus absorption and translocation in corn. (2ea mays). Proc. Soil Sci. Soc. Am. 27: 671-674.

DALE, J.E. 1964. Some effects of alternating temperature on the growth of French bean plants. Annals Botany, 28: 127-135. 
DANTAS, J.P. 1978. Comunicação pessoal.

DART, P. J. e F. V. MERCER, 1965. The effect of growth tempe rature, level of ammonium nitrate and light intensity on the growth and nodulation of cowpea (Vigna sinensis Ena]. ex. Hassk). Aust. J. Agr. Res. 16: 321-345.

DART, P. J. E D. C. WILDON, 1970. Nodulation and Nitrogen fí xation by Vigna sinensis and Vicia stropurpurea: The influence of concentration, form, and site of application of combined Nitrogen. Aust. J. agric. Res., 21: 45-56.

DART, P. J. 1974. The infection process. In: QUISPEL, A. The Biology of Nitrogen fixation. North-Holland Publ. Comp., Amsterdam. p. 382-429.

DEVLIN, R. M. 1975. Fisiologia Vegetal. Ed. Omega S.A. Barcelona, $468 \mathrm{p}$.

DOBEREINER, J. 1966. Manganese toxicity effects on nodula tion and nitrogen fixation by beans (Phaseolus vulgaris L.) in acid soils. Plant Soil. 24(1): 153-166.

DOBEREINER, J. ; N. B. ARRUDA e A. F. PENTEADO, 1966. Avaliação da fixação do nitrogênio, em leguminosas, pela regres são do Nitrogênio total das plantas sobre o peso dos nódu 1os. Pesq. agropec. bras. 1: 233-237. 
DOBEREINER, J. e N.B. ARRUDA. 1967. Interrelações entre varie dades e nutrição na nodulação e simbiose da soja. Pesq. agropec. bras. 2: 475.487 .

DOBEREINER, J. 1971. Inoculação cruzada e eficiência na simbiose de leguminosas tropicais. In: As Leguminosas na Agricul tura tropical. Anais do Sem. sobre Metodologia e Planejanen to de Pesquisa com Leguminosas Tropicais. IPEACS - UFRRJ. p. $181-192$.

DUNCAN, W.C. e A.J. OHLROGGE. 1958 . Principles of nutrient uptake from fertilizer bands. II. Root development in the band. Agronomy J., 50: 605-608.

DUTRA, L.G.; J. PEREIRA; J.M. BRAGA e A.S. REGO. 1975. Efeito da adubação nitrogenada, fosfatada e potássica na pradução da soja (Glycine max (L) Merril) e do feijão (Phaseolus vuz garis L.) em latossolo vermelho escuro extrutura média, nos Municípios de Goiânia e Anāpolis, Goiās. Rev. Ceres, 22 (123): $341-358$.

EDJE, 0. T. ; L. K. MUGHOGHO e U. W. U. AYONOADY. 1975. Respon ses of dry beans to varying nitrogen levels. Agronomy J. 67: $251-255$.

EPSTEIN, E. 1975. Nutrição Mineral das Plantas. Princípios e Perspectivas. Trad. E. MALAVOLTA; Editora da L. S. P. $341 \mathrm{p}$.

F. A. 0., 1974. Statistical Yearbook Twenty Fifth Issue. United Nations. New York, 829 p. 
FERRARI, E. ; S.M. SOUTO e J. DOBEREINER. 1967. Efeito da temperatura do solo na nodulação e no desenvolvimento da soja perene (Glycine javanica, L.). Pesq. agropec. bras. 2 : 461-466.

FONTES, L. A. N. 1972. Nota sobre efeitos da aplicação do adu bo nitrogenado e fosfatado, calcário e inoculante na cultura do feijão (Phaseolus vulgaris, L.). Rev. Ceres, 19 (103): $211-216$.

FOY, C.D. ; A.L. FLEMING ; G.R. BURNS e W.H. ARMIGER, 1967. Characterization of differential Al tolerance among varieties of wheat and barley. Soil sci soc. Amer. Proc. 31 : 513-521.

FOY, C. D. ; A. L. FLEMING e G.C. GERLOFF, 1972. Differential Aluminum tolerance in two Snapbean varieties. Agronomy J. $\underline{64}(6): \quad 815-818$.

FOY, C. D., 1974. Effects of Aluminum on plant growth. In: The Plant root and its environment. CARSON, E.W.Ed. The Univ. Press. of Virginia, Charlottesville, p. 601-642.

FRANCO, A.A. e J. DOBEREINER. 1968. Interferência do Ca e N na fixação sümbiótica do $N$ por duas variedades de phaseolus un garis. Pesq. agropec. bras. 3: 223-227.

FRANCO, A.A. 1977. Micronutrients requirement in Legume-Rhizobium symbiosis in the tropics. In: Int. Symposium on the 1 i mitations and potentials of biological nitrogen fixation jn the tropics. Brasilia, p. 55 . 
FRANÇA, G.E. e M.M. CARVALHO. 1970. Ensaio exploratório de fertilização de cinco leguminosas tropicais em um solo de cerrado. Pesq. agropec. bras., Rio de Janeiro, GB, 5: 147-153.

FREIRE, J.R.J. e C. VIDOR. 1971 . Fatores limitantes dos solos a cidos na simbiose de Rhizobium e as leguminosas. In: As leguminosas na Agricultura trooical. Anais do Seminário sobre metodologia e planejamento de pesquisa com leguminosas tropí cais. IPEACS, P. $211-247$.

FROUSSIOS, G. 1970. Genetic diversity and agricultural potencial in Phaseolus vulgaris L. Exp1. Agric. 6:129-141.

FURTADO, C. 1974. Formação Econômica do Brasil. Cia. Editora Naciona1, São Paulo, 12 a. Ed. 248 p.

GALLO, J.R. e S. MIYASAKA. 1961. Composição química do feijoeiro e absorção de elementos nutritivos, do florescimento à matu ração Bragantia. 20 (40): $867-884$.

GAUCH, H.G. 1973. Inorganic Plant Nutrition. Dowden Hutch \& Ross, Inc. Ed. Stroudsburg., Pa. 488 p.

GIBSON, A. H. 1971. Factors in the physical and biological envi ronment affecting nodulation and nitrogen fixation by legumes. Plant Soil. Spec. Vo1. 139-152.

GIBSON, A.H. 1974. Consideration of the growing legume as symbiotic association. Proc. Ind. Nat. Sci. Acad. 40 B (6): $741-$ 767.

GIBSON, A.H. 1976. Recovery and compensation by nodulated legumes to environmental stress. In: NUTMAN, P.S. Ed. Cambridge Univ. Press., London, Symbiotic nitrogen fixation in plants, p. $385-343$. 
GIBSON, 1976a. Limitation to Dinitrogen fixation by Legumes. In: Proc. Ist. Int. Symposium on Nitrogem Fixation. W.E. NEWTON e C.J. NYMAN. Eds. Washington State Univ. Press. Pullman. p. 507-517.

GIBSON, A.H. 1977. Lectures on Rhizobium, Legumes, and their Symbiosis. Curso Intensivo sobre fixação de Nitrogênio nos Trópicos. EMBRAPA. UFRRJ. $68 \mathrm{p}$.

GIBSCN, A.H. e J.D. PAGAN, 1977. Nitrate effects on the nodulation of legumes inoculated with Nitrate-reductase-deficient Mutants of Rhizobium. Plants. 134: 17-22.

GOEPFERT, C.F. 1972. Experimento sobre o efeito residual da adu bação fosfatada em feijoeiro (Phaseolus vulgaris). Agron. Sul riograndense, 8 (1): 41-47.

GRAHAM, P.H. e J. HALLIDAY. 1976. Inoculation and nitrogen fixa tion in the genus phaseolus. In: VIII Reunião Latino-America na de Rhizobium. Cali, Colómbia. p. 313-334.

GROBBELAAR, N. ; B. CLARKE e M.C. HOUGH. 1971. The nodulation and nitrogen fixation of isolated roots of Phaseolus vulgaris L. II. The influence of light on nodulation. Plant soil. Spec. Vol.: 203-214.

GURLEY, W.H. e J. GIDDENS. 1969. Factors affecting uptake,yield response and carryover of Mo in soybean seed. Agronomy I. 61: $7-9$.

HAAG, H.P.; E. MALAVOLTA; H. GARGANTINI e H. GARCIA BlanCO. 1967. Absorção de nutrientes pela cultura do feijoeiro. Bragantia, 26 (30): $381-391$. 
HABISH, H.A. 1970. Effect of certain soil condition on nodulati on of Acacia spp. Plant Soil, 33: 1-6.

HABISH, H.A. e H.M. ISHAG. 1974. Nodulation of legumes in the Sudan. III. Response of Haricot Bean to inoculation. Expl. Agric. 10 (1): 45-50.

HALLIDAY, J.H. 1976, Energy and Nitrogen fixation. In: VIII Reu nión Latinoamericana de Rhizobium. Cali, Colombia. 38 p.

HARDY, R.W.F.; R.D. HOLSTEN; E.K. JACKSON e R.C. BURNS . 1968 . The Acetylene-Ethylene Assay for $\mathrm{N}_{2}$ Fixation: Laboratory and Field Evaluation. Plant Physiol. 43: 1185-1207.

HARDY, R.W.F. ; R.C. BURNS e R.D. HOSTEN. 1973. Application of the Acetylene-Ethylene assay for measurement of Nitrogen fixation. Soil Biol. Biochem. 5: 47-81.

HARDY, R.W.F.; P. FILNER e R.H. HAGEMAN. 1975. Nitrogen imput. In: LAMBORG, M; S.K. RIES, F.H. TSCHIRLEY e S.H. WITTWER . (organizers). Crop Productivity - Research Imperatives Michi gan Agr. Exp. Sta., East Lansing. p. 133-176.

HAUSENBUILLER, R.L. 1975. Soil Science. Principles and Practices. Ed. WM, C. Brown Comp. Pub1. Dubuque, Iowa. 504 p.

HELLENDOORN, E.W. 1969. Intestinal effects following ingestion of beans. Food Techno1. 23: 87-91.

HEWITT, E.J. e T.A. SMITH. 1975. Plant Mineral Nutrition. English Univ. Press, Ltd. Ed. St. Paul's House, Warwick Lane, London, $298 \mathrm{p}$.

HIROCE, R. ; J.R. GALLO e H.A.A. MASCARENHAS. 1970. Análise foliar em feijoeiro. II. Diagnose da nutrição fosfatada. Bra gantia, 29 (Nota 2): 7-12. 
HOAGLAND, D.R. e D.I. ARNON. 1950. The water-culture method for growing plants without soil. Califórnia Agr. Exp. Sta. Circ. 347 .

IMBAMBA, S.K. 1973. Response of cowpea to salinity and (2-chloroethyl) trimethyl-ammonium chloride (CCC). Phsiol. Plant. 28: $346-349$.

JONES, R.K. 1968. Initial and residual effects of superphosphate on a Townsville lucerne pasture in north east Queensland.

Aust. J. exp. Agric. Anim. Husb. 8: 521-527.

JONES, M.B. e L.M.M. FEITAS. 1970. Respostas de quatro legumino sas tropicais ásforo, Potassio e Calcário num latossolo vermelho-amarela de campo cerrado. Pesq. agropec.Bras. 91-99.

JONES, R.K. 1974. A study of the phosphorus responses of a wide range of accessions from the genus stylosanthes. Aust. J. agric. Res. 25: $847-862$.

KALDY, M.S. 1972. Protein yield of various crops as related to protein value. Econ. Botany, 26: 142-144.

KAMPRATH, E.J. e C.D. FOY. 1971. Lime - fertilizer plant interactions in acid soils. In: McVICKAR, M.H., G.L. BRIDGER $e$ L.B. NELSON (Ed.) Fertilizer - Technology and Use. Soil Soc. Mad. p. 105-151.

KANG, B.T. 1975. Effects of inoculation and nitrogen fertilizer on soybean in western Nigeria. Expl. Agric. 11 (1): 23-31.

KEFFORD, N.P. J. BROCKWELL e J.A. ZWAR. 1960. The symbiotic syn thesis of auxin by legumes and nodule bacteria and its role in nodule development. Aust. J. biol., 13:456-457. 
KEMPTHORNE, 0.1973. The design and Analys is of Experiments. Robert E. Krieger Publ. Comp., Huntington, New York, 631 p.

KENNEDY, I.R.; J. Rigaud e J.C. TRICHANT. 1975. Nitrate reductase from bacteroids of Rhizobium japonicum: Enxyme characteristics and possible interactions with nitrogen fixation. Biochim. Biophys. Acta, 397: 24-35.

KLIEWER, W.M. e W.K. KENNEDY. 1960. Studies on response of legu mes to molybdenium and lime fertilization on Martinsilt loam soils. Soil Sci. Soc. Amer. Proc. 24 (5): 377-380.

KOCH, B. e H.J. EVANS. 1966. Reduction of acetylene to ethylene by soybean root nodules. Plant Physiol. 41: 1748-1749.

KOLLING, J. ; G.G. STAMMEL e E. KORNELIUS. 1974. Efeitos da calagem e da adubação fosfatada sobre a nodulação, nitrogênio total no tecido e produção de matéria seca de leguminosas forrageiras de clima tropical. Agron. Sulriograndense, 10 (2): $267-280$.

KOLLING, J. ; J.G. STAMMEL e E. KORNELIUS. 1976. Efeitos do ca1 cárfo e da adubação fosfatada sobre alguns componentes químicos do tecido de leguminosas forrageiras de clima tropical. Agron. Sulriograndense, 12 (2): 207-218.

LAERA, N.T. J.M. DAY e A.A. FRANCO. 1977. Effect of calcium and $\mathrm{pH}$ on the response of $\mathrm{N}_{2}$ - fixation to Mo fertilizer in Phaseolus vulgaris. In: Int. Symposium on the limitations and potentials of biological nitrogen fixation in the tropics. Brasilia.p. 99 .

LAHAYE, P.A. e E. EPSTEIN. 1971. Calcium and salt toleration by bean plants. Physiol. Plant. 25 (2): 213-218. 
LAMBERT, J. e B. TOUSSAINT: 1977. The effect of phosphate fertilizer on the yield and phosphorus uptake of the princiapl grass species. Phosphorus in Agriculture. 69: 15-22.

LEHNINGER, A.L. 1975. Biochemistry. 2nd. Ed. Worth Publish., Inc. New York, $1104 \mathrm{p}$.

LIE, T.A. e S. BROTONEGORO. 1969. Inhibition of root-nodule fox mation in leguminous plants by EDTA. Plant Soil, 30 (2): 339 342 .

LIE. T.A. 1969a. Non-photosynthetic effects of red and far light on root nodule formation by leguminous plants. Plant Soil, 30: $391-403$.

LIE, T.A. 1969b. The effect of low pH on different phases of no dule formation in pea plants. Plant Soil, 31(3): 391-406.

LIE, T.A. 1971. Symbiotic nitrogen fixation under stress condi tions. Plant Soil. Spec. Vol. 117-127.

LIE, T.A. 1974. Environmental effects on nodulation and symbiotic nitrogen fixation. In: QUISPEL, A. The Biology of Nitro gen Fixation. North-Holland Publ. Comp., Amsterdam. p. 555582 .

LOHNIS, M.P. 1951. Manganese toxicity in field and market graden crops. Plant Soil, 3: 193-222.

LONERAGAN, J.F. 1959. Calcium in the nitrogen metabolism of sub terranean clover. Aust. J. biol. Sci. 12: 26-39.

LONERAGAN, J.F. 1972. The soil chemical environment to symbiotic nitrogen fixation. In: Use of Isotopes for study of Fer tilizer utilization by legume crops. I.A.E.A., Viena. p. 17 54 . 
LONGERI, L. e O.N. ALLEN. 1970. Efecto de Calcio y Magnesio en el crecimiento de Rhiaobium trifolli en la fijacion de Nitro geno em simbiosis com Trizobium pratense. In: IV Reunião La tinoamericana sobre Inoculantes para Leguminosas. Porto Alegre.p. $35-39$.

LOPEZ, O.E.G. e E. MALAVOITA. 1974. Estudos sobre as relações entre Zinco e fósforo na nutrição da planta. In: Anais da E.S.A. "Luiz de Queiroz", Piracicaba. 31: 467-483.

LOWTHER, W.L. e J.F. LONERAGAN. 1970. Calcium in the nodulation of legumes. Proc. XI Int. Grassid. Congr. Queensiand, Austra iia. p. $446-450$.

MALAvoltA, E. 1967. Manual de Quimica Agricola. Adubos e Aduba ção. Ed. Agronômica Ceres Ltda. 2a. Ed. 606 p.

MAlavolta, E. 1972. Nutrição e Adubação. In: Anais do I Simpósio Brasileiro de Feijão. Campinas, p. 2211-242.

MALAVOLTA, E. ; H.P: HAAG; F.A.F. MELLO e M.O.C. BRASIL SOBRo. 1974. Nutrição Mineral e Adubação de Plantas Cultivadas. Li vraria Pioneira Editora. São Paulo. $727 \mathrm{p}$.

NAlavolta, E. 1975. Práticas de Nutrição Mineral de f́lantas. C. P.G. de Solos e Nutrição de Plantas. ESALQ/USP. Piracicaba. $65 \mathrm{p}$.

MALAvolTA, E. 1976. Manual de Quimica Agricola. Nutrição de Plantas e Fertilidade do Solo. Ed. Agronomica Ceres Ltda. 528. 
MALDONADO, G.F. e A.C. NEVES. 1971. Preferências Alimentares e consumo de alimentos e nutrimentos em dez áreas do território brasileiro. In: Anais do 30 simpósio Brasileiro de Alimentação e Nutrição, Belo Horizonte. $260 \mathrm{p}$.

MASEFIELD, G.B. 1968. Seasonal effects on the root nodulation of legumes. Expl. Agr. 4: $335-338$.

MASEFIELD, G.B. 1971. The root nodulation of tall and dwarf peas beans. Exp1. Agr. I (2): 123-127.

MEAGHER, W.W., C.M. JOHNSON e P.R. STOUT. 1952. Molybdenum requirement if leguminous plants suplied with fixed nitrogen. plant Physiol. 27 (2): 223-230.

MIFLIN, B.J. e P.J. LEA. 1976. The pathway of Nitrogen assimila tion in plants. Phytochemistry. 15 (6): 873-885.

MIYASAKA, S. ; E.S. FREIRE e H.A.A. MASCARENHAS . 1963. Modo e poca de aplicação de Nitrogênio na cultura do feijoeiro Bragantia. $22(40): 511-519$.

MOOY, C.J. e J. PESEK. 1966. Nodulation response of Soybeans to added Phosphorus, Potassium, and Calcium Salts. Agronomy. J. 58 (3): $275-280$.

MORRIS, H.D. e W.H. PIERRE. 1949. Minimum concentrations of man ganese necessary for injury to various legumes in culture so lutions. Agronomy J. 41: 107-112.

MULDER, E.G. A S. BROT́TONEGORO. 1974. Free-living heterotropic nitrogen-fixing bacteria. In: QUISPEL, A. The Biology. of Nitrogen Fixation. North-Holland Publ. Comp., Amsterdam. p.

MUNNS, D.N. 1968a. Nodulation of Medicago sativa in solution culture. II. Compensating effects of nitrate and of prior nodulation. Plant Soil, 28(2): 246-257. 
MUNNS, D.N. 1968b. Nodulation of Medicago sativa in solution culture. I. Acid-sensitive steps. Plant Soil, 28 (1): 129-146.

MUNN, D.N. 1969. Enzymatic breakdown of Pectin and Acid-Inhibi tion of the infection of Medicago roots by Rhizobium. Plant Soil, 30 (1): 117-120) Short communication).

MUNNS, D.N. e R.L. FOX. 1977. Comparative 1 ime requirements of tropical and temperate legumes. Plant Soil, 46:533-548.

MUNNS, D.N. ; R.L. FOX e B.L. KOCH. 1977. Influence of lime on nitrogen fixation by tropical and temperate legumes. Plant Soi1 46: 591-601.

NICHOLAS, D.J.D. 1975. The functions of trace elements in plants. In: NICHOLAS, D.J.D. e A.E. EGAN. Trace Elements in SoilPlant-Animal Systems. Academic Press, Inc. New York, London. p. $181-198$.

NORRIS, D.0.1965. Rhizobium relationships in legumes. In: Ann. IX Congr. Int. Pastagens. São Paulo. P. 1087-1092.

NORRIS, D. 0. 1967. The intelligent Use of legume inoculants and lime pelleting of tropical legumes. Trop. Grassld.1: 107-121.

NUTMAN, P.S. 1972. The influence of physical environmental factors on the activity of Rhizobium in soil and in symbiosis. In: Use of Isotopes for Study of fertilizer utilization by Legume crops. I.A.E.A., Viena. P. 55-83.

ODU, C.T.I.;A.A. FAYEMI e J.A. OGUNWALE. 1971. Effect of pH on the growth, nodulation and nitrogen fixation of Centrose ma pukescens and Stylosanthes gracilis. J. Sci. Fd. Agric. 22: 57-59. 
OGHOGHORIE, C.G.O. e J.S. PATE. 1971. The nitrate stress syndro me of the nodulated field pea (Pisum arvense L.). Techniques for measurement and evaluation in physiological terms. Blant Soil. Spec. Vol. p. 185-202.

ORTEGA, M.L. ; C.C. RODRIGUEZ e X.E. HERNANDEZ. 1974. Analisis bioquimica exploratorio de grano de los genotipos de Phaseolus vulgaris L. e Phaseolus coccineus cultivados en Mexico. Fitotecnia Latinoamericana 10 (1): 70-74.

PARKINSON, J.A. e S.E. ALLEN. 1975. A wit oxidation procedure suitable for the determination of nitrogen and mineral nutrients in biological material. Commun. Soil Sci. Plant A$\underline{\text { nalysis, }}$ 6 (1): $1-11$.

PATE, J.S. e P.J. DART. 1961. Nodulation studies in legumes. Plant Soil, 15: $329-346$.

PAZ, L.G. e A.O. LOBÃO. 1976. Aspectos fisiológicos da de folia ção em pastagens. Zootecnia, Nova Odessa (SP), 14 (2): 91108 .

PIMENTEL GOMES, F., 1970. Curso de Estatistica Experimental, 4‥ Ed. Liv. Nobel S.A. São Paulo. 430 P.

PONS, A.L. 1975. Efeito da Calagem e da adubação Nitrogenada em feijoeiro. Agron. Sulriograndense. 11 (2): 251-257.

POSTGATE, J. 1974. Prerequisites for biological nitrogen fixati on in free-living heterotrophic bacteria. In: QUISPEL, A. The Biology of Nitrogen Fixation. North-Holland Publi. Comp. Amsterdam. p. 663-685. 
PRADO, E.C. ; C. VIEIRA e H.A. ROBITAILLE. 1976. Comportamento de variedades trepadoras de feijão (Phaseolus vulgaris L.) cultivadas com tutoramento. Revista Ceres. 23 (130) 519-526.

RAGGIO, M. N. RAGGIO e J.G. TORREY. 1967. The nodulation of isolated leguminous roots. Am. J. Bot. 44: 325-334.

RAGGIO, N., M. RAGGIO e R.H. BURRIS. 1959. Nitrogen fixation by nodules formed on isolated bean roots. Biochem. Biophys. Ac ta. $32: 274-275$.

RAGGIO, M e N. RAGGIO. 1962. Root nodules. Ann. Rev. Plant Phy sio1. 13: 109-128.

RAGGIO, M. ; N. RAGGIO J.G. TORREY. 1965. The interaction of nitrate and carbohydrates in Rhizobial root nodule formation. Plant Physiol. 40 (4):601-606.

RANGA RAO, V. 1977. Effect of temperature on the Nitrogenase Ac tivity of intect and detached nodules in Lotus and stylosan thes J. Exp. Botany, 28 (103):261-267.

REIS, B. F. 1978. Comunicação pessoal.

RICE, W.A. : D.C. PENNEY A M. NYBORG. 1977. Effects of soil acidity on Rhizobia numbers, nodulation and nitrogen fixation by alfafa and red clover. Can. J. Soil sci. 57 (2): 197

RIGAUD, J. ; F.J. BERGERSEN ; G.L. TURNER e R.M. DANIEL. 1973. Ni trate dependent anaerobic acetylene-reduction and nitrogen fixation by soybean bacteroids. J. gen. Microbiol. 77. 137 144.

ROGERS, V.E. 1969. Depression of nitrogen uptake and growth of lucerne at high soil temperatures. Field sta. Record. Division of Plant Industry. CSIRO, Australia, 8: 37-44. 
ROVIRA, A.D. 1969. Plant root exudates. Bot. Rev. 35: 35-57.

RUSCHEL, A.P., D.P.P. SOUZA BRITTO e J. DOBEREINER. 1966. Fixação simbiótica de Nitrogênio atmosférico em feijão (PhaseoZus vulgaris) L.). II. Influência do Magnésio, do Boro, do Molibdênio e da Calagem. Pesq. agropec. bras. 1: 141-145.

RUSCHEL, A.P. ; R. ALVAHYDO e I.B.M. SAMPAIO. 1968. Influência do excesso de alumínio no feijão (Phaseolus vulgaris L.) cul tivado em solução nutritiva. Pesq.agropec. bras. $3: 229-$ 233.

RUSCHEL, A.P., D.P.P. SOUZA BRITTO e L.F. CARVALHO. 1969, Efeito do Boro, Molibdênio e Zinco quando aplicados ao revestimento da semente na fixação simbiótica do Nitrogênio atmosférico da Soja (Glycino max (L.) Merril). Pesq.agropec.bras. 4 : $29-37$.

RUSCHEL, A.P. e H.W. REUSZER. 1973. Desenvolvimento da nodula ção e fixação simbiōtica de nitrogênio em variedades de soja, em diferentes estádios do desenvolvimento da planta. Pesq. agropec. bras. 8: 251-256.

RUSCHEL, A.P. e H.W. REUSZER. 1973a. Fatores que afetam a simbiose Rhizobium phaseoli - Phaseolus vulgaris. Pesq. agropec. bras. 8: 287-292.

RUSCHEL, A.P. ; R. RUSCHEL ; D.L. ALMEIDA e A.R. SUHET. 1974. In fluência do nitrogênio mineral e orgânico na fixação simbiōtica de nitrogênio em soja. Pesq.agropec. bras. 9: 125-

RUSCHEL, A.P. e R. RUSCHEL. 1975. Avaliação da fixação simbiótí ca de nitrogênio em feijão. Pesq. agropec. bras. 10: 11-17. 
RUSCHEL, A.P. e S.M.T. SAITO. 1977. Efeito da inoculação de $\underline{\underline{\text { Rhi }}}$ zobium, nitrogẽnio e matéria orgânica na fixação simbiótica de nitrogênio em feijão (Phaseolus vulgaris L.). Rev. bras. Ciência do Solo. 1 (1): 21-24.

RUSCHEL, A.P. 1977. Comunicação pessoal.

RUSCHEL, A.P. ; E. SALATI e P.B. VOSE. 1977. Nitrogen enrichment of soil and plant by Rhizobium phaseoli-Phaseolus vulga ris symbiosis. (Short communication).

RUTGER, J.N. 1970. Variation in protein content and its relations to other characters in beans (Phaseolus vulgaris L.). Report of the tenth dry beans research conference. Agricultu . ral Research Service. p. 59-69.

SAITO, S.M.T. e A.P. RUSCHEL. 1976. Influência da calagem, adubação fosfatada e micronutrientes na nodulação natural do feijão (Phaseolus vulgaris L.). In: VIII Reunião Latino-Americana do Rhizobium. Cali, Colobia. 11 p.

SCOTT, D.B. 1978. Recent developments in the biochemistry of $\mathrm{Ni}$ trogen fixation in the legume - Rhizobium symbiosis. Ciência e Cultura. 30 (2): 185-194.

SIMONSEN ASSOCIADOS, 1976. Projeto Feijão, Planejamento Marketing, CNEM, São Paulo.

SING, J.N. e H.J. MACK. 1966. Effects of soil temperatures on growth, fruiting and mineral composition of snap beans. Proc. Amer. Soc. Hort. Sci. 88: 378-383.

SISTACHS, E. 1970. Effect of $N$ fertilization and inoculation on yield and $N$ content of black beans (Phaseolus vulgaris). Rev. cubana Cienc. agric. 4: 227-230. 
SKINNER, K.J. 1976. Nitrogen Fixation. Chem. \& Eng. News, 54 (41): $22-35$.

SMALL, J.G.C. e O.A. LEONARD. 1969. Translocation of $\mathrm{C}^{14} 1 \mathrm{abel-}$ led photosynthate in nodulated legumes as influenced by nitrate nitrogen. Am. J. Bot. 56:187-194.

SNEDECOR, G.W. e W.G. COCHRAN. 1974. Metodos Estadisticos. Comp. Editorial Continental S.A. México. 703 p.

SOLHEIM, B. e J. RAA. 1971. Evidence countering the theory of specific induction of pectin degrading enzymes as basis for specifity in Rhizobium-Leguminosae ssociation. Plant Soil, $35: 275-280$.

SOMERS, I.I. e J.W. SHIVE. 1942. The Iron-Manganese relation in Plant Metabolism. Plant Physiol. 17 (4): 582-602.

SUUTO, S.M. e J. DOBEREINER. 1969. Toxidez de manganês em leguminosas forrageiras tropicais. Pesq.agropec. bras. 4: 129138 .

SOUTO, S.M. e J. DOBEREINER. 1970. Efeito da temperatura do solo na fixação de nitrogênio em alfafa do Nordeste (Stylosanthes gracilis) e kudzu tropical (Fueraria javanica). Pesq. agropec. bras. 5: $365-371$.

STAMFORD, N.P. ; A.B. CAMPELO e J. DOBEREINER. 1968. Nódulos pretos eficientes e ineficientes e sua inoculação cruzada em várias leguminosas In: Anais da IV Reunião Latinoamericana sobre Inoculantes para Leguminosas, Porto Alegre.

TANNER, J.W. e I.C. ANDERSON. 1963. An external effect of inor ganic nitroger ir root nodulation. Nature, 198: 303-304. 
TANNER, J.W. e I.C. ANDERSON. 1964. External effect of combined nitrogen on nodulation. Plant Physiol. 39: 1039-1043.

TERRY, N. 1977. Photosynthesis, Growt, and the role of Chloride. Plant Physiol. 60 (1): 69-75.

TONHAZY, N.E. e M.J. PELCZAR Jr. 1954. Oxidation of indoleactic acid by an extracellular enzyme from Polyporus versicolor and e similar oxidation catalyzed by nitrate. Science, 120 : 141-142.

TULMANN NETO, A. 1975. Contibuição ao melhoramento do feijoeiro (Phaseolus vulgaris L.) visando aumentar a quantidade e melhorar a qualidade da proteína. Piracicaba. ESALQ/USP. $150 \mathrm{p}$.

UNGER, P.W. e R.E. DANIELSON. 1967. Water relations and growth of beans (Phaseolus vulgaris L.) as influenced by nutrient solution temperatures. Agronomy J. 59 (2): 143-136.

VAN SCHREVE, D.A. 1959. Effects of added sugars and nitrogen on nodulation of legumes. Plant Soil., 11: 93-112.

VICENT, J.M. 1965. Environmental factors in the fixation of nitrogen by the legumes. In: BARTHOLOMEW, W.V. e F.E. CLARK. Soil Nitrogen. Agronomy no 10. Amer. Soc. Agron. Inc. Madison, Wis. p. 384-435.

VICENT, J.M. 1974. Root-nodule symbioses with Rhizobium. In: QUISPEL, A. The Biology of Nitrogen fixation. North-Holland Pub1. Comp., Amsterdam. p. 265-341.

VICENT, J.M. 1975. Manual Practico de Rizobiologia. Editorial Hemisferio Sur. Buenos Aires. 220 p. 
VIRTANEN, A.I. e J.K. MIETTINEN. 1963. Biological Nitrogen Fixa tion. In: STEWART, F.C. (Ed.) Plant Physiology. A Treatise. Academic Press, Inc. New York. p. 539-668.

WARNOCK, R.E. 1970. Micronutrient uptake and mobility within corn plants (2ea mays L.) in relation to phosphorus-induced zinc deficiency. Soil Sci Soc. Amer. Proc. 34: 765-769.

WERNER. J.C. e H.B. MATTOS. 1974. Ensaio de fertilização com a 1 guns micronutrientes em soja perene (Glycine wightii, willo.) In: VIIa. Reunión Latinoamericana sobre Rhizobium, Resistência, Chaco, Argentina. Universidad Nacional del Nordeste. p. 354-371.

WHITEAKER, G. ; G.C. GERLOFF ; W.H. GABELMAN e D. L.INDGREN. 1976 . In traspecific differences in growth of Beans at stress levels of phosphorus. J. Amer. Soc. Hort. Sci. 101 (4): 472-475.

WHITEMAN, P.C. 1970. Distribution and weight of nodules in tropical pasture legumes in the field. Expl. Agric. 7: 75-85.

WIGNARAJAH, K. ; D.H. JENNINGS e J.F. HANDLEY. 1975a. The effect of salinity on growth of Phaseolus vulgaris L. I. Anatomical changes in the first trifoliate leaf. Annals Botany. $39(164): 1029-1038$.

WIGNARAJAH, K. ; D.H. JENNINGS e J.F. HANDLEY. $1975 \mathrm{~b}$. The effect of salinity on growth of Phaseolus vulgaris I. II. Effect on Internal solute concentration. Annals Botany. 39 (164): 1039 1056 .

WORTHEN, E.L. e S.R. ALDRICH. 1967. Suelos agricolas, su Conser vaciōn y Fertilizaciōn. Uniōn Tipografica Editorial Hispano

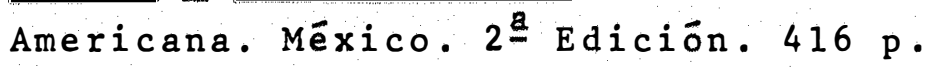


WUTKE, A.C.P. 1975. Acidez. In: MONIZ, A.C. Elementos de Pedolo gia. Livros Técnicos e Científicos Editora S.A. Rio de Janeiro. p. 149-189. 
152.

9 - $A$ P N D I C 


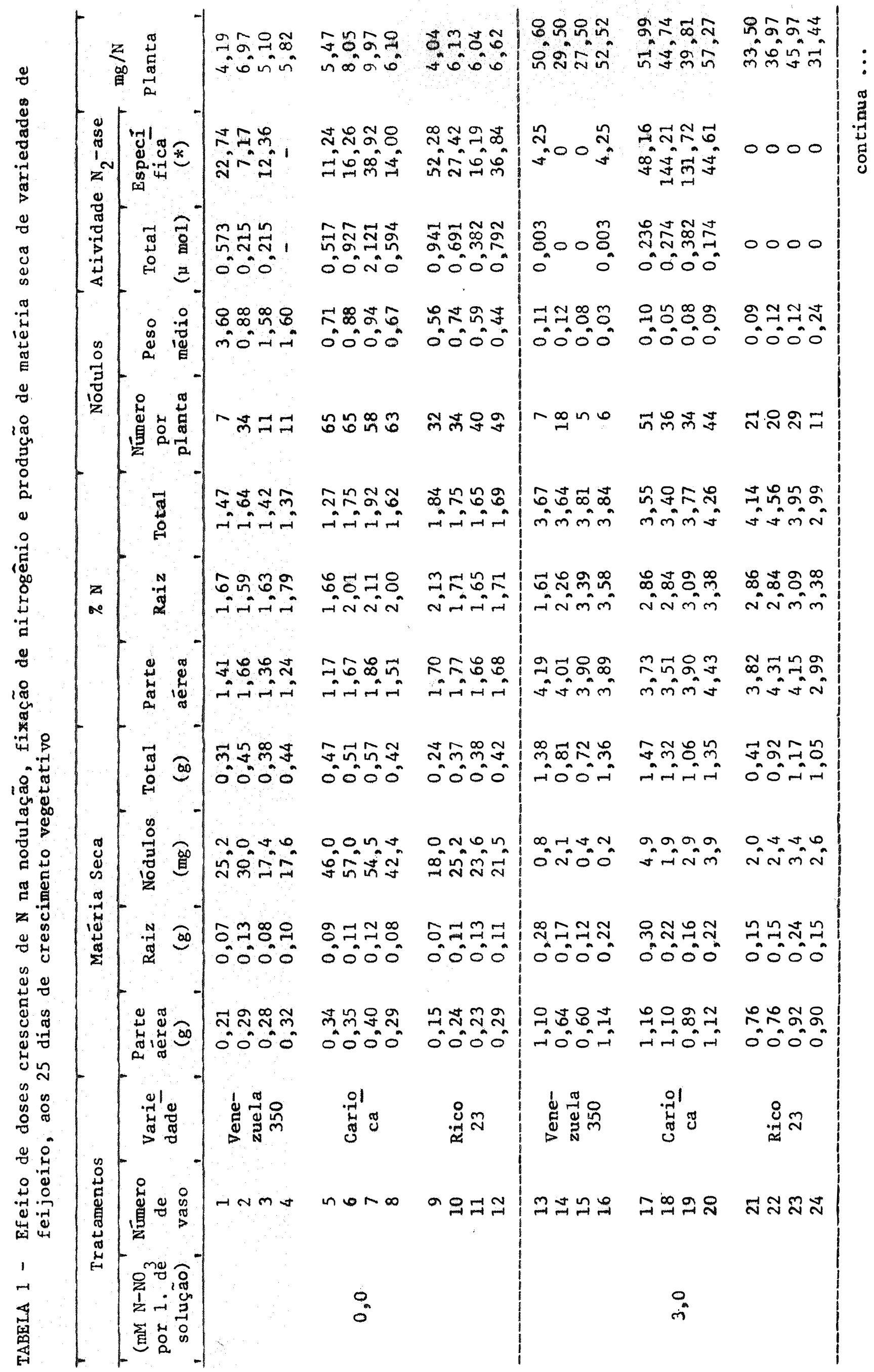




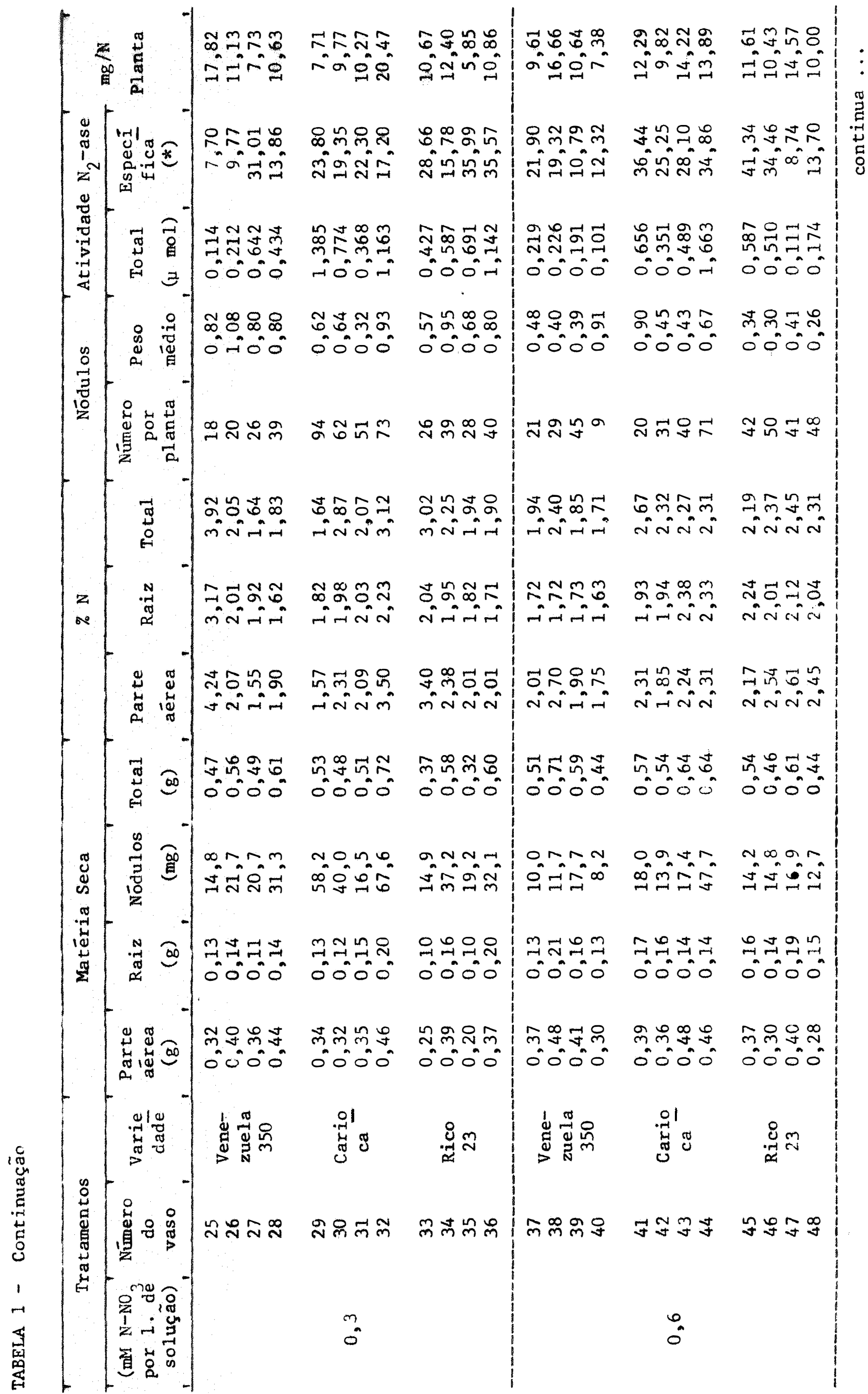




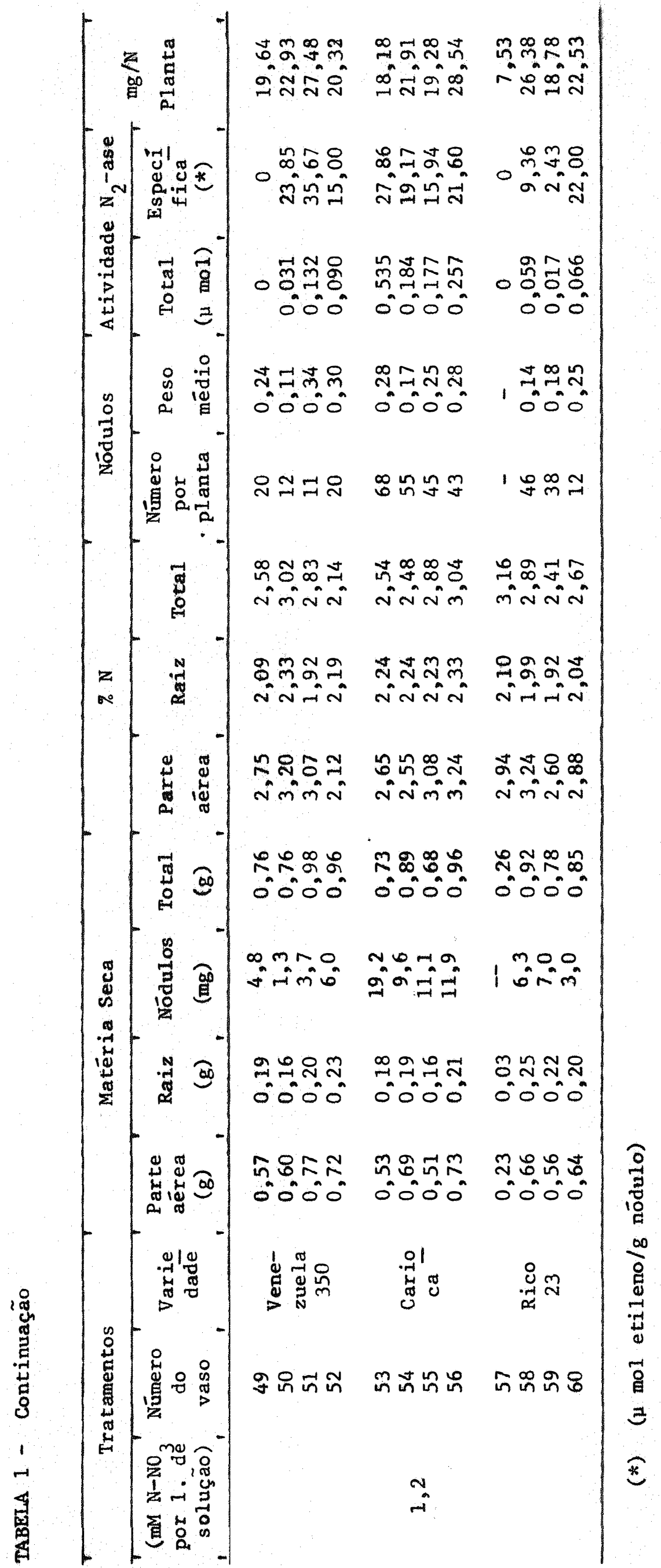




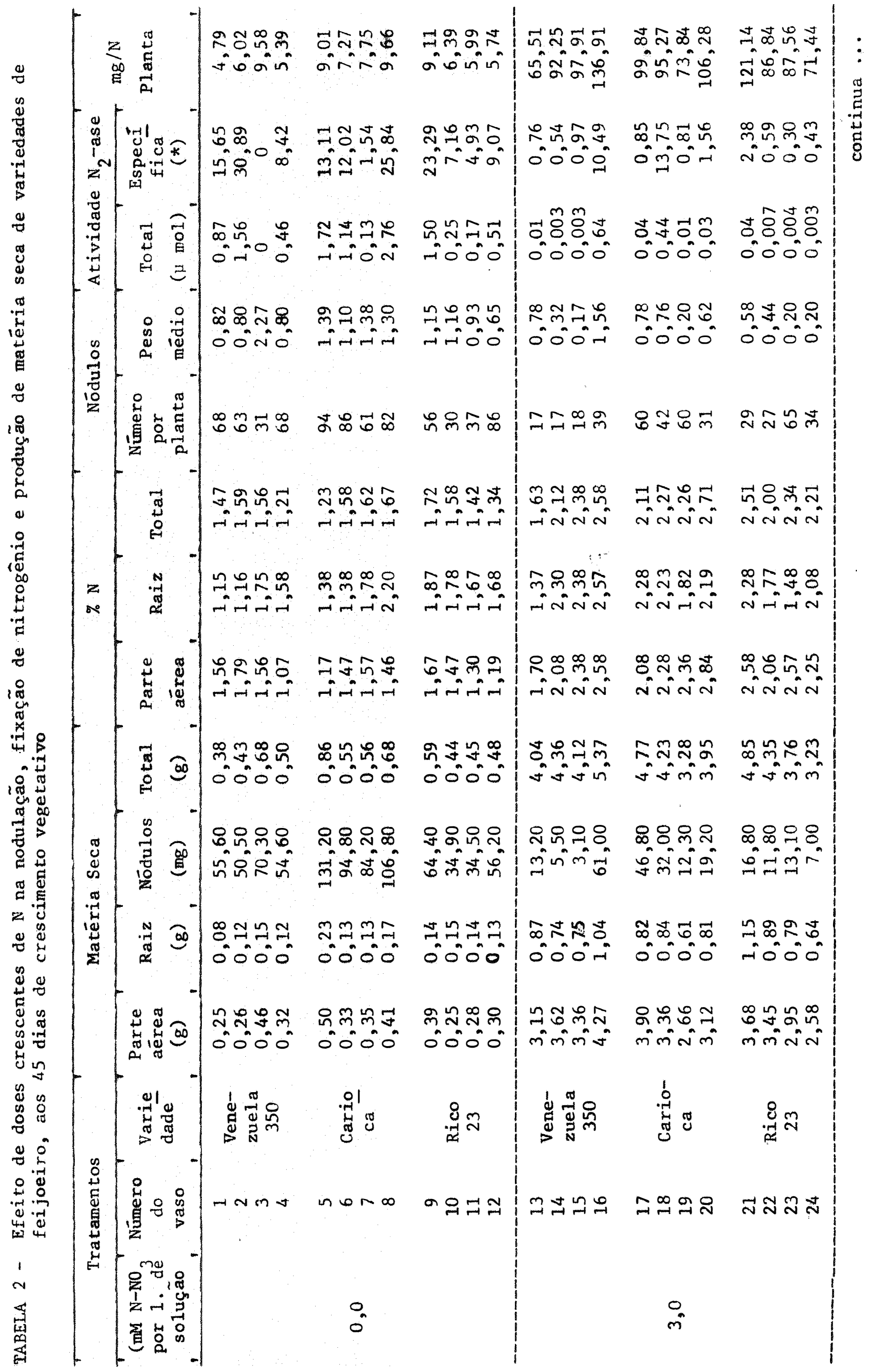




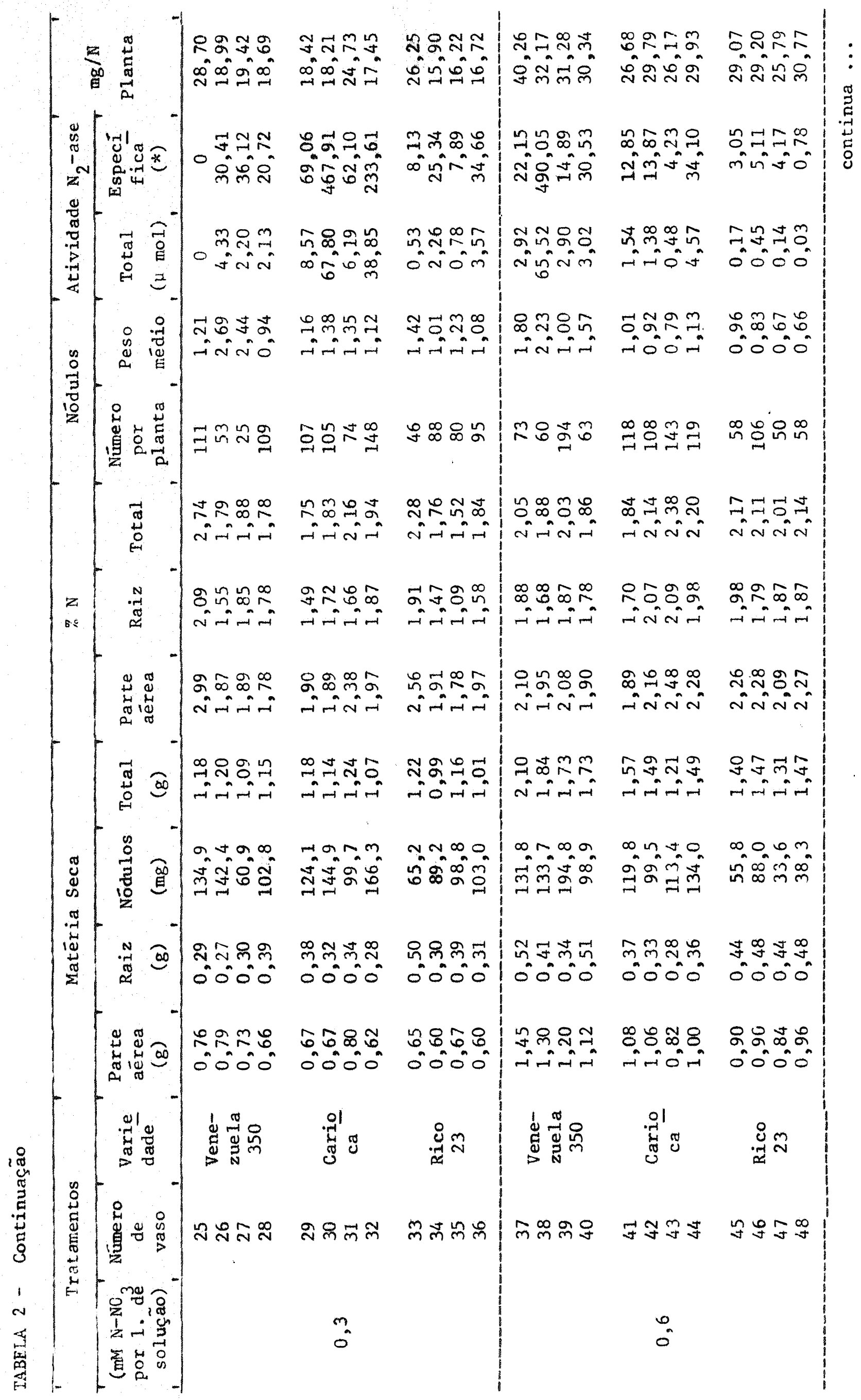




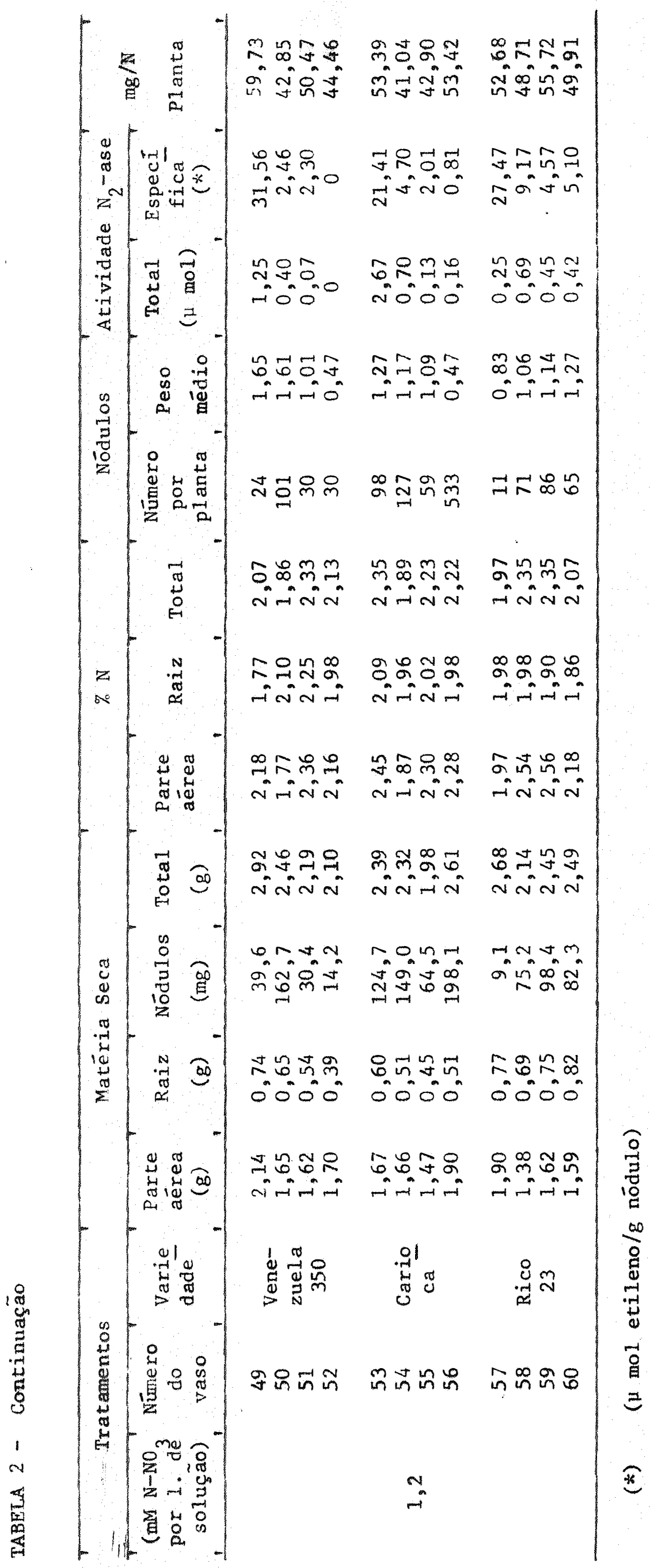




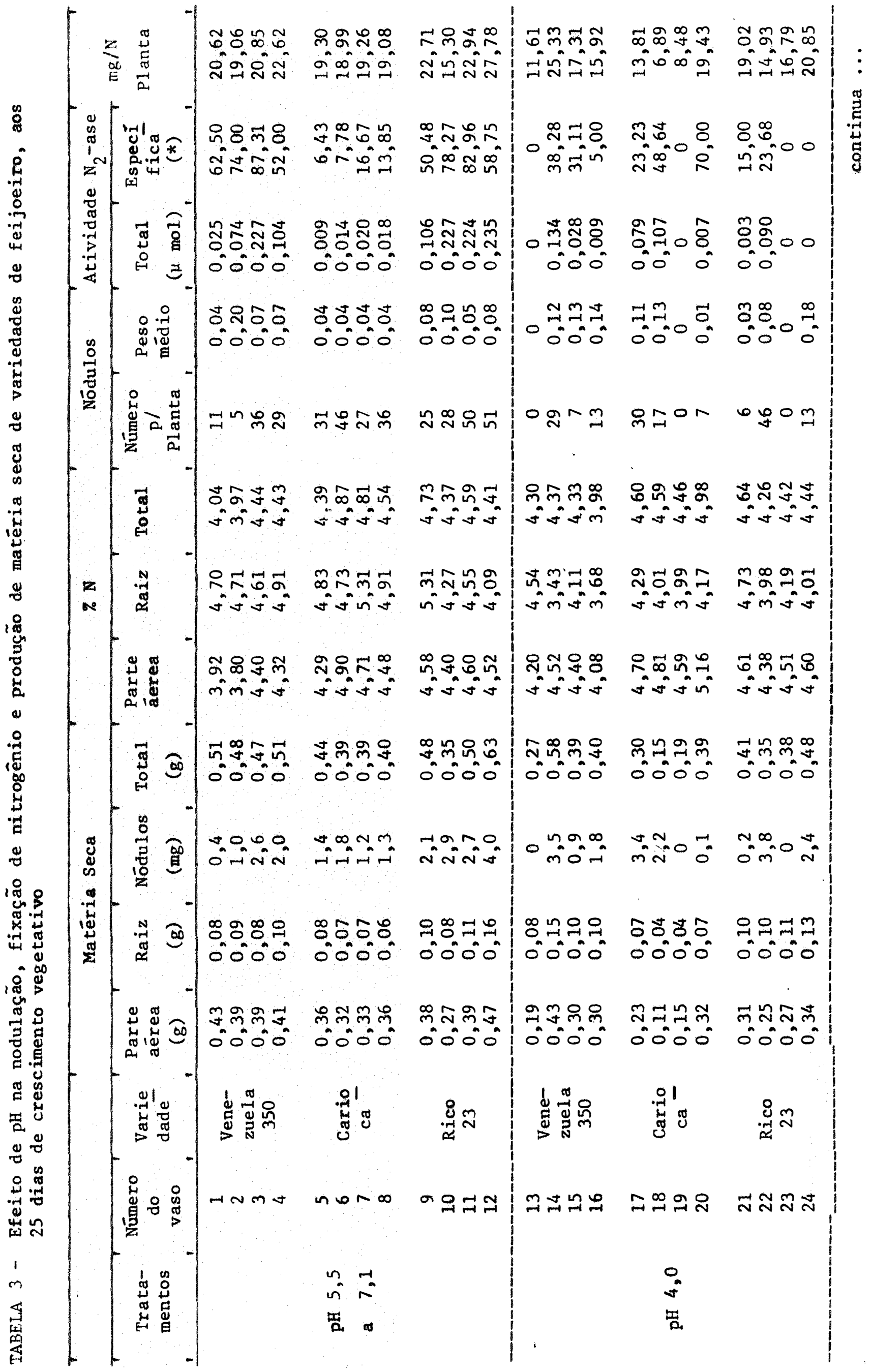




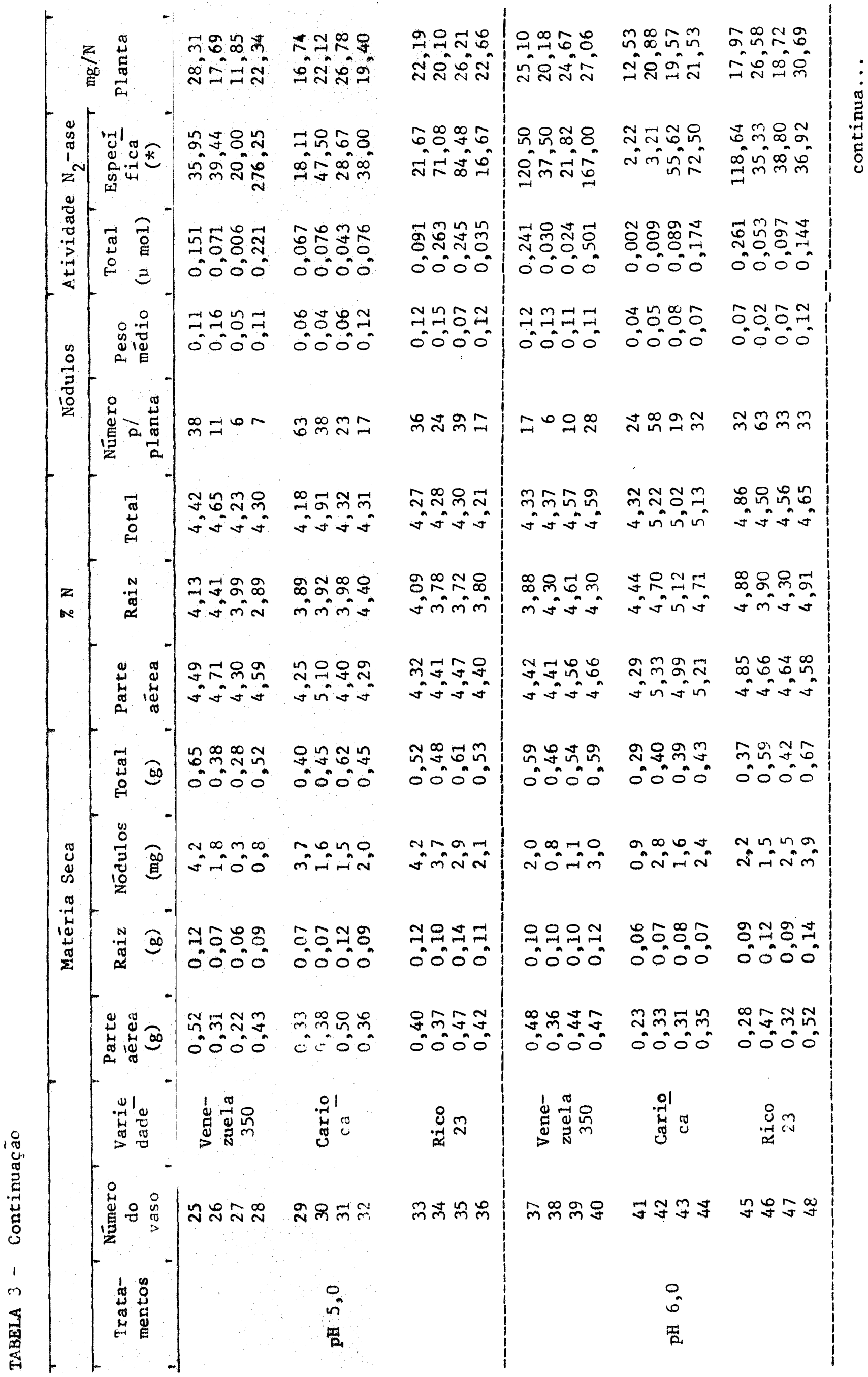




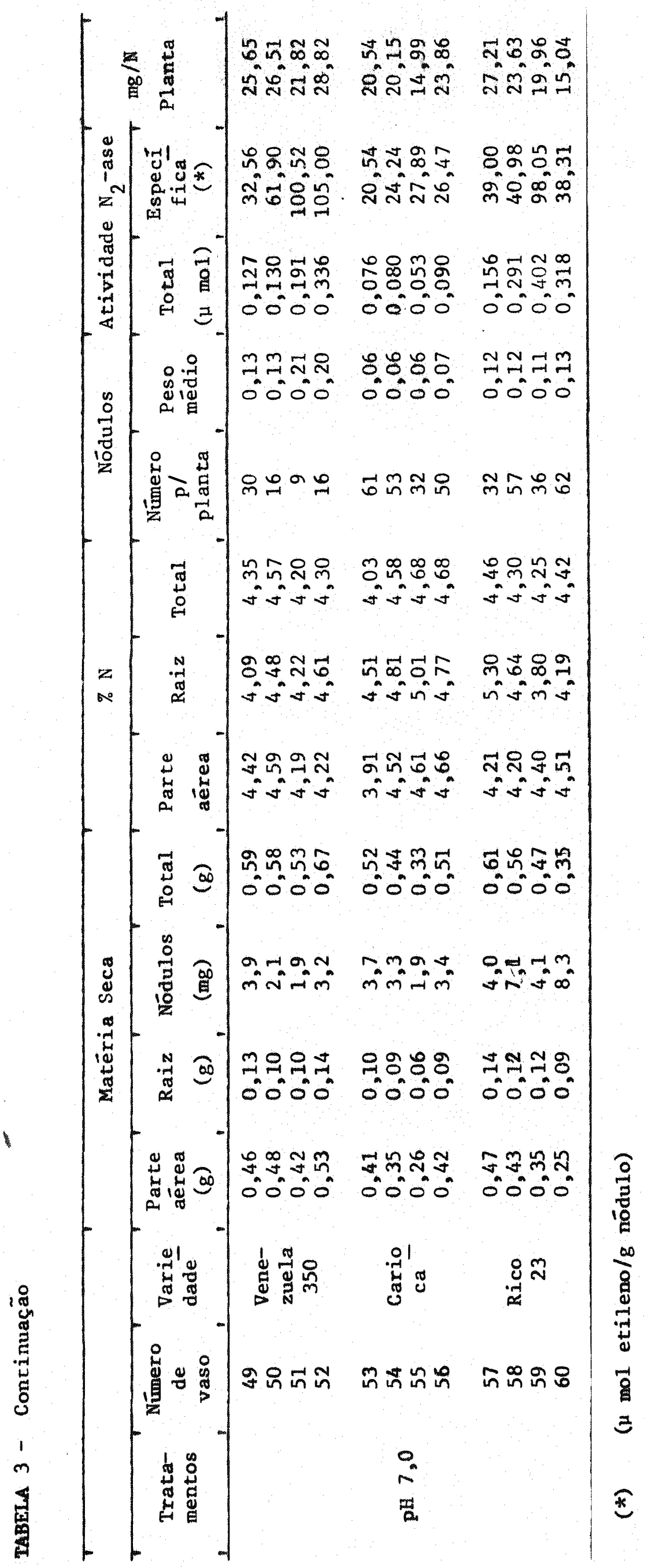




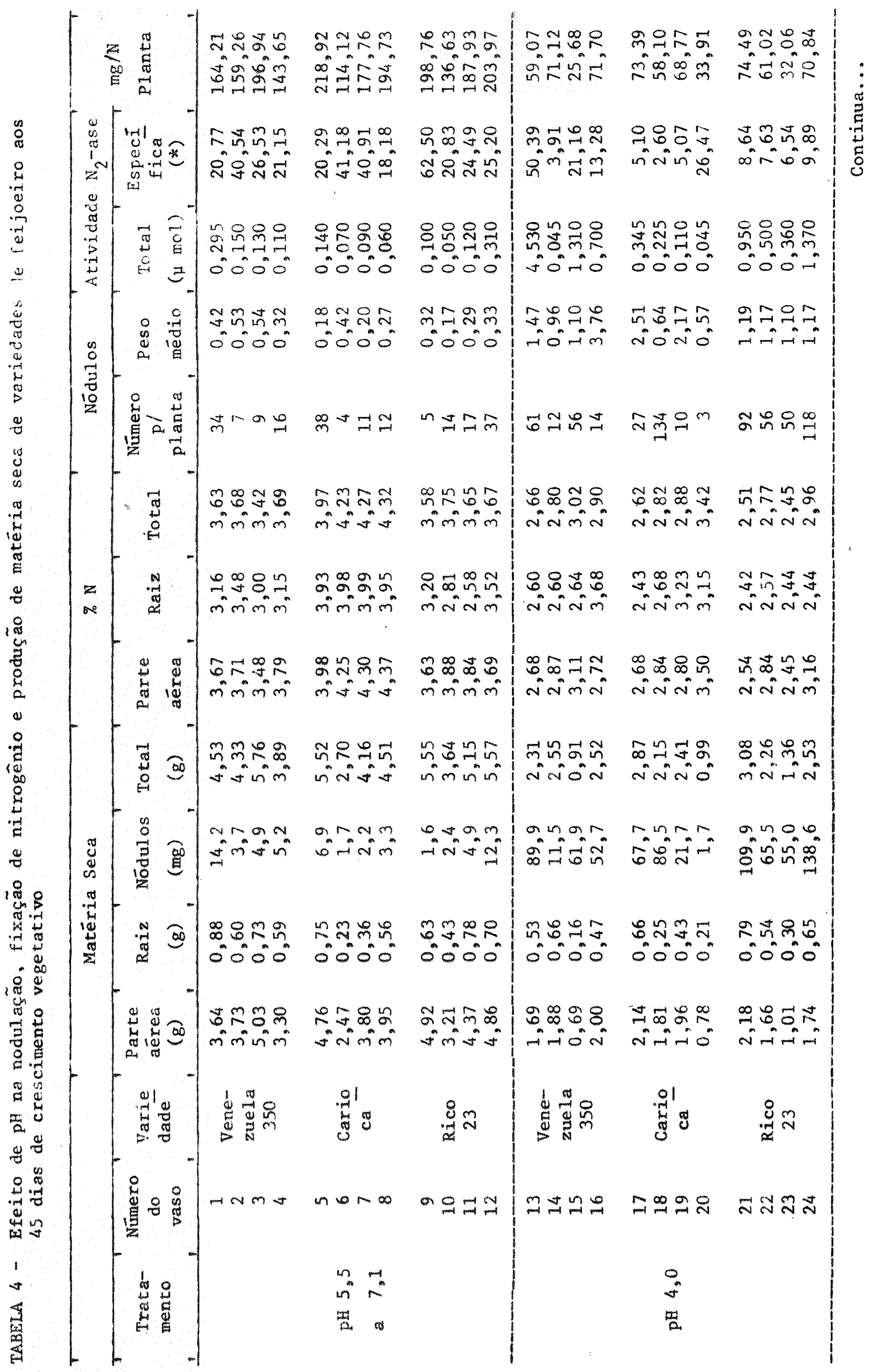




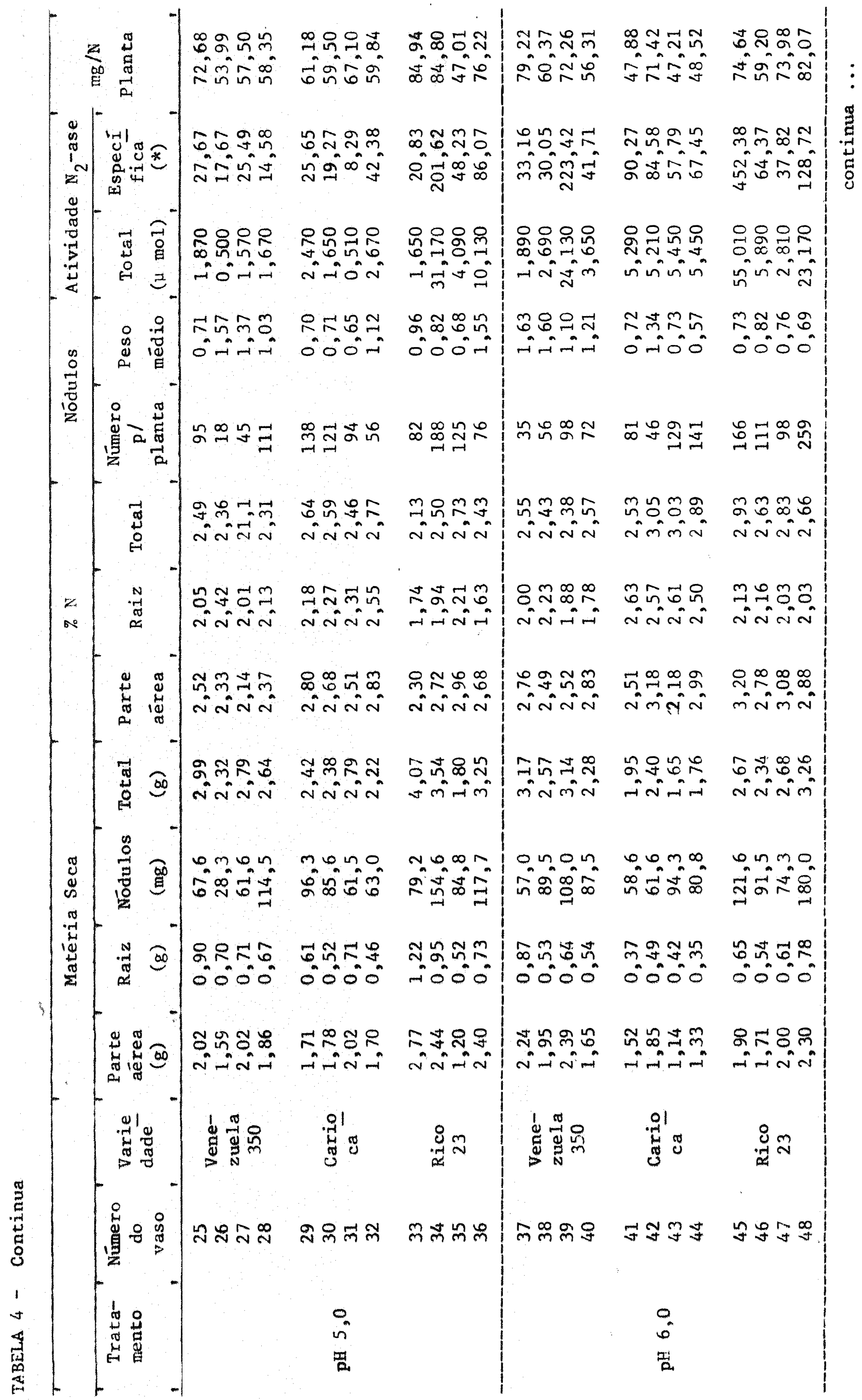




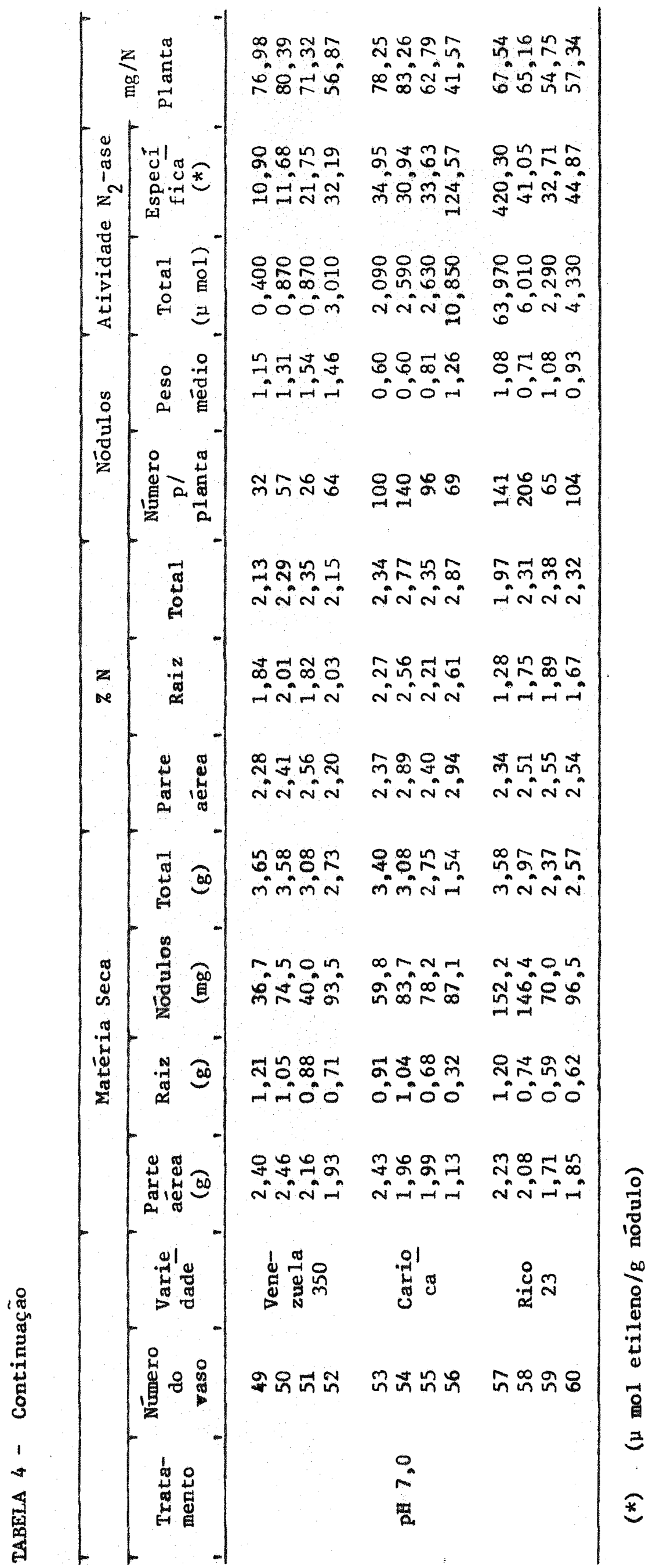




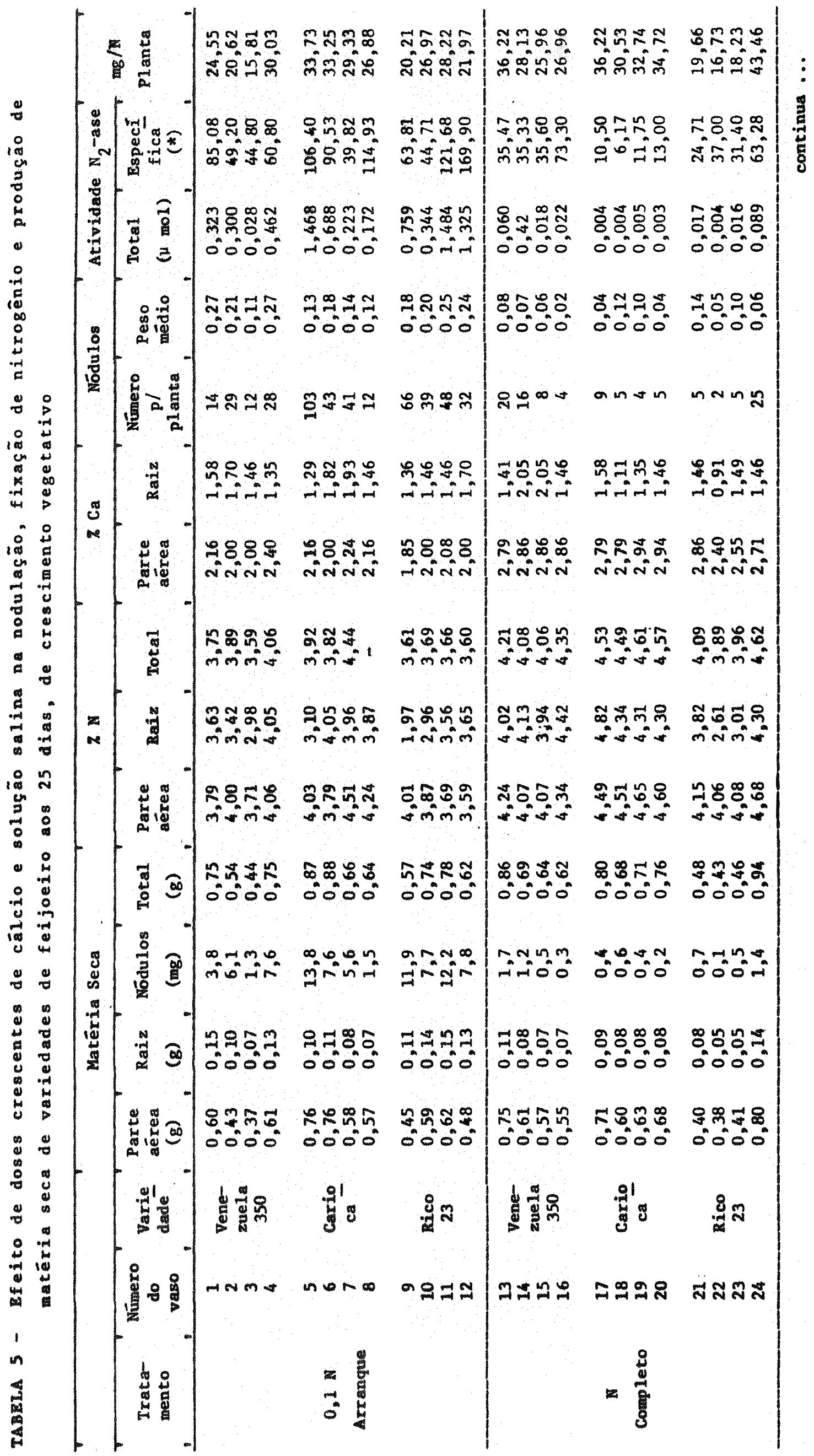




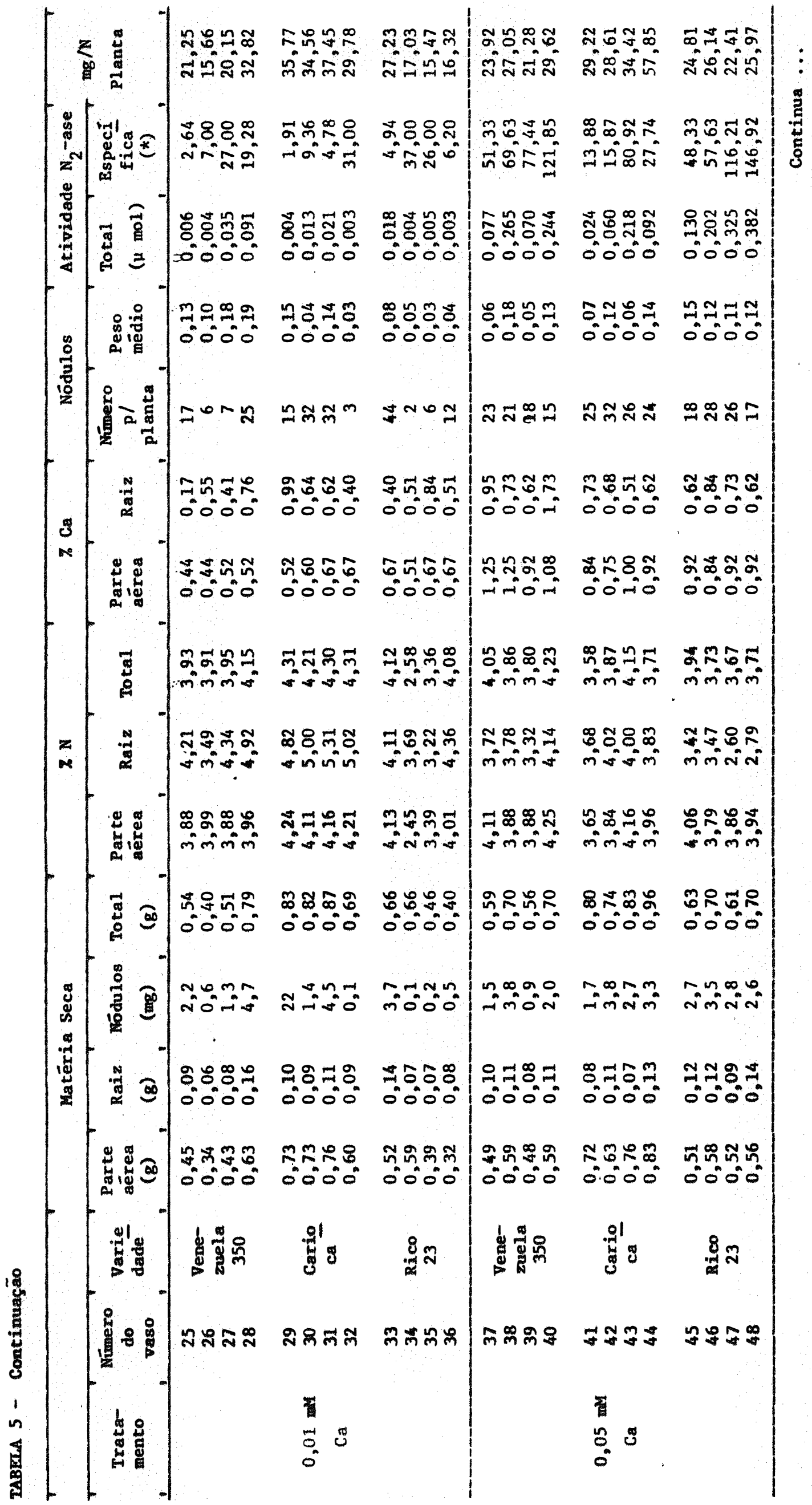




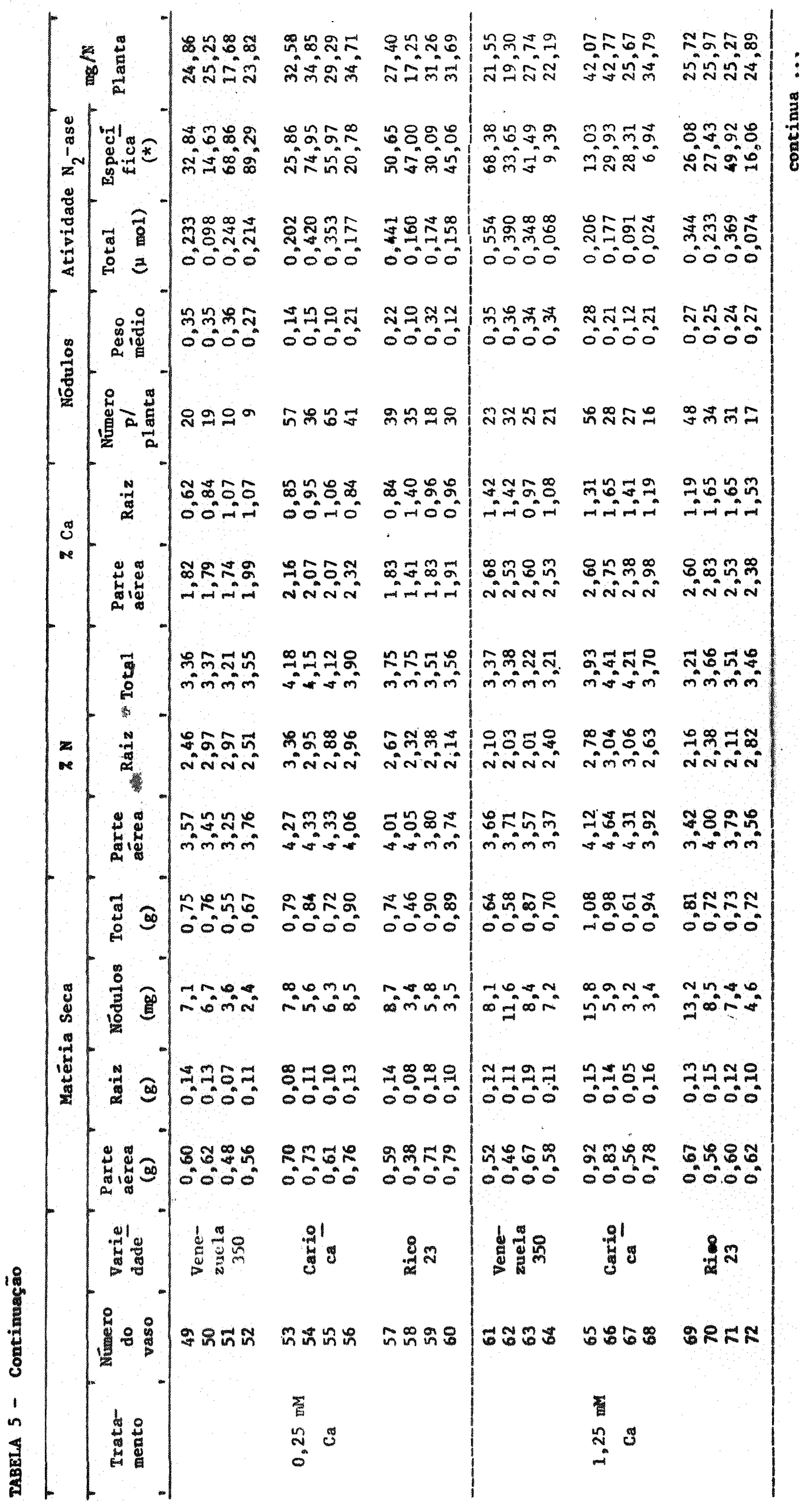




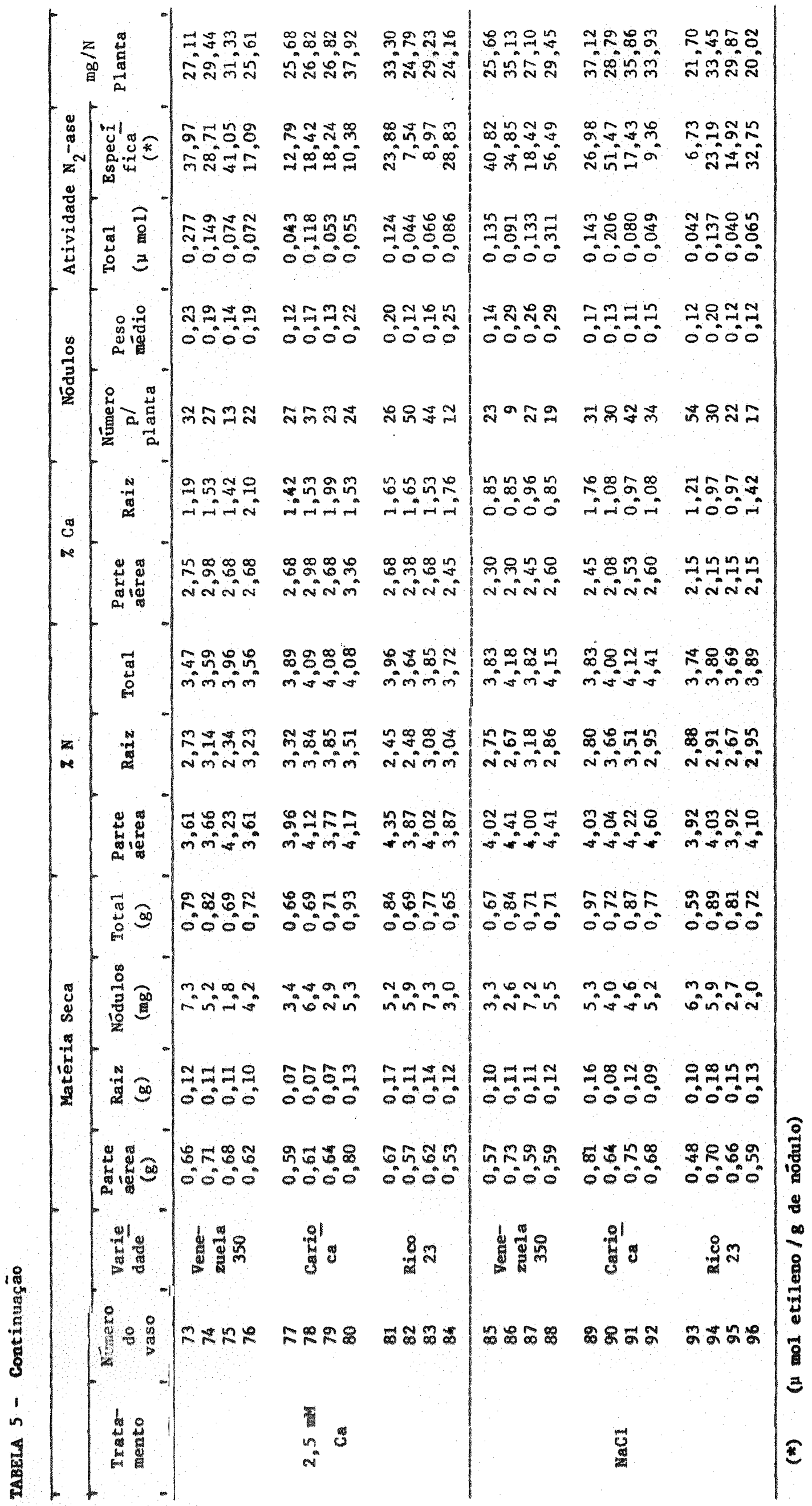




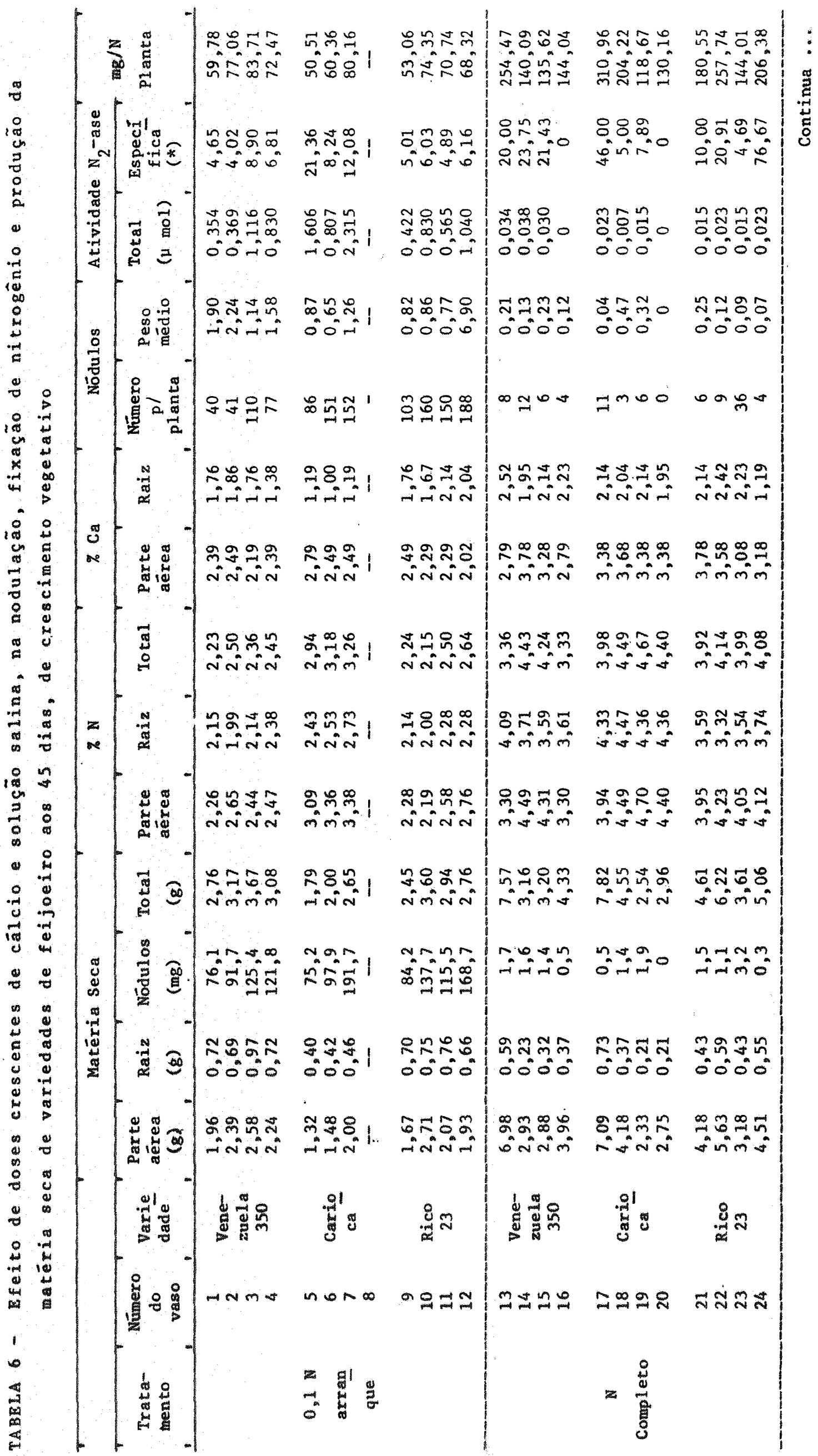




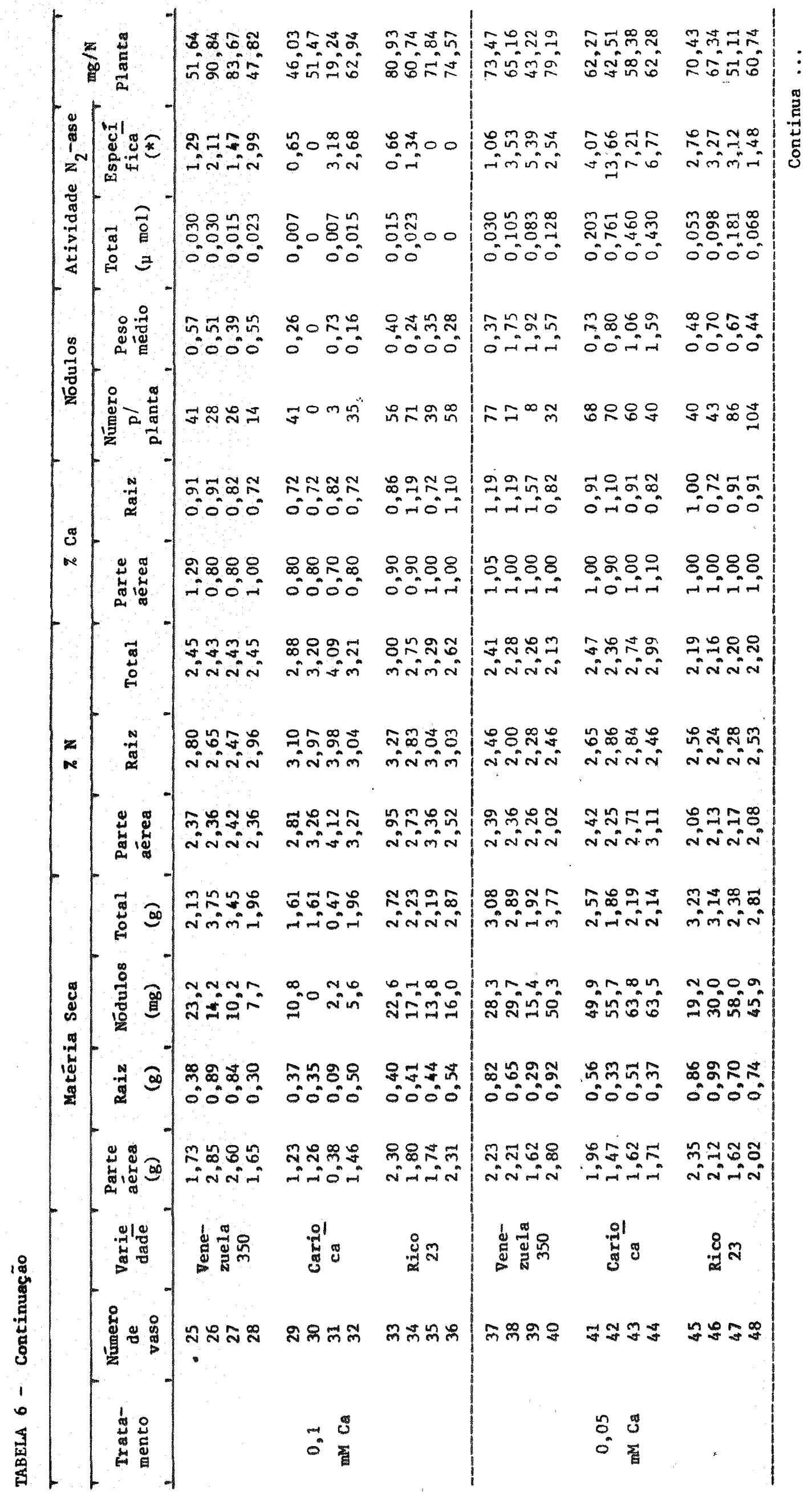




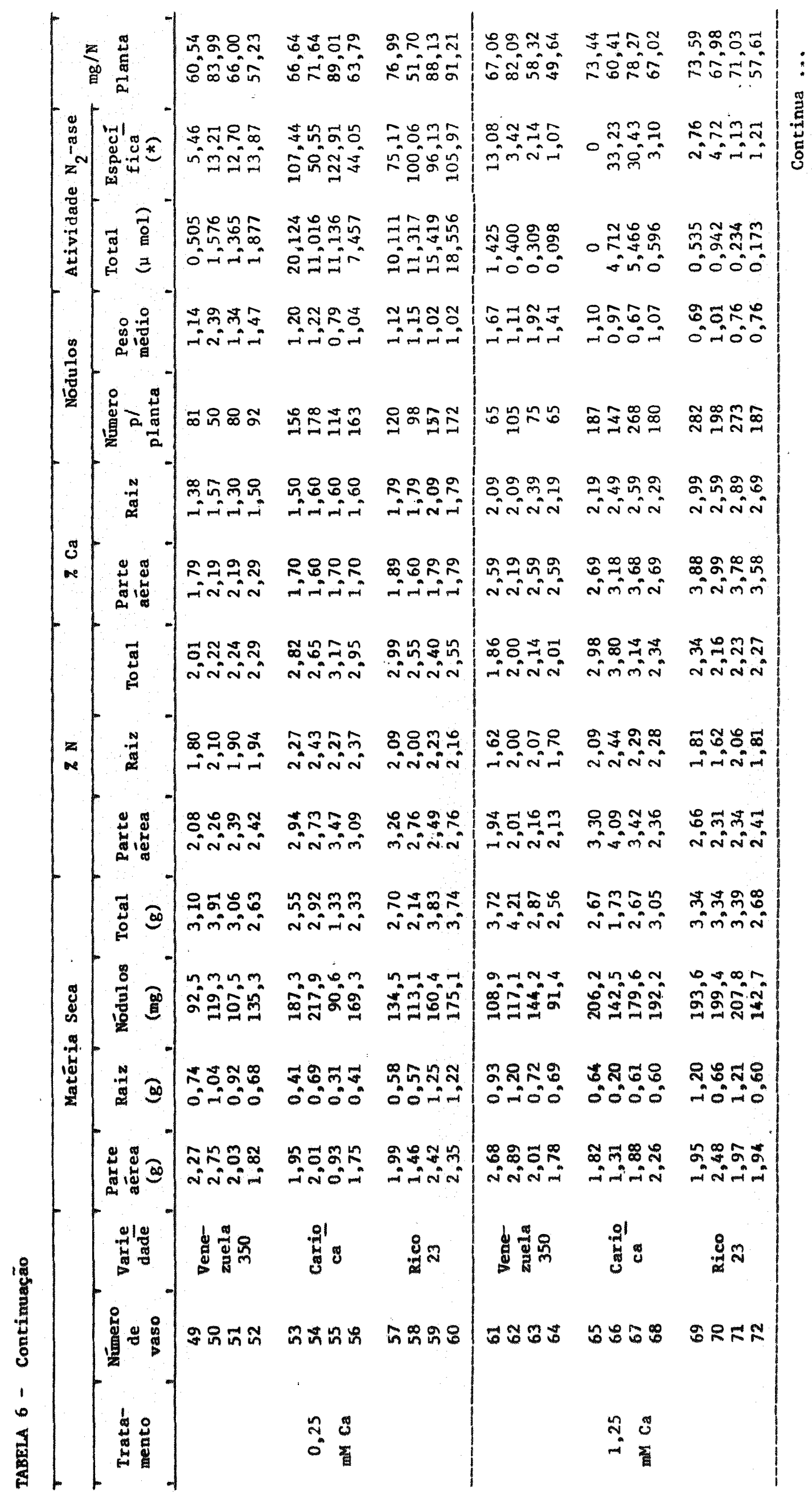




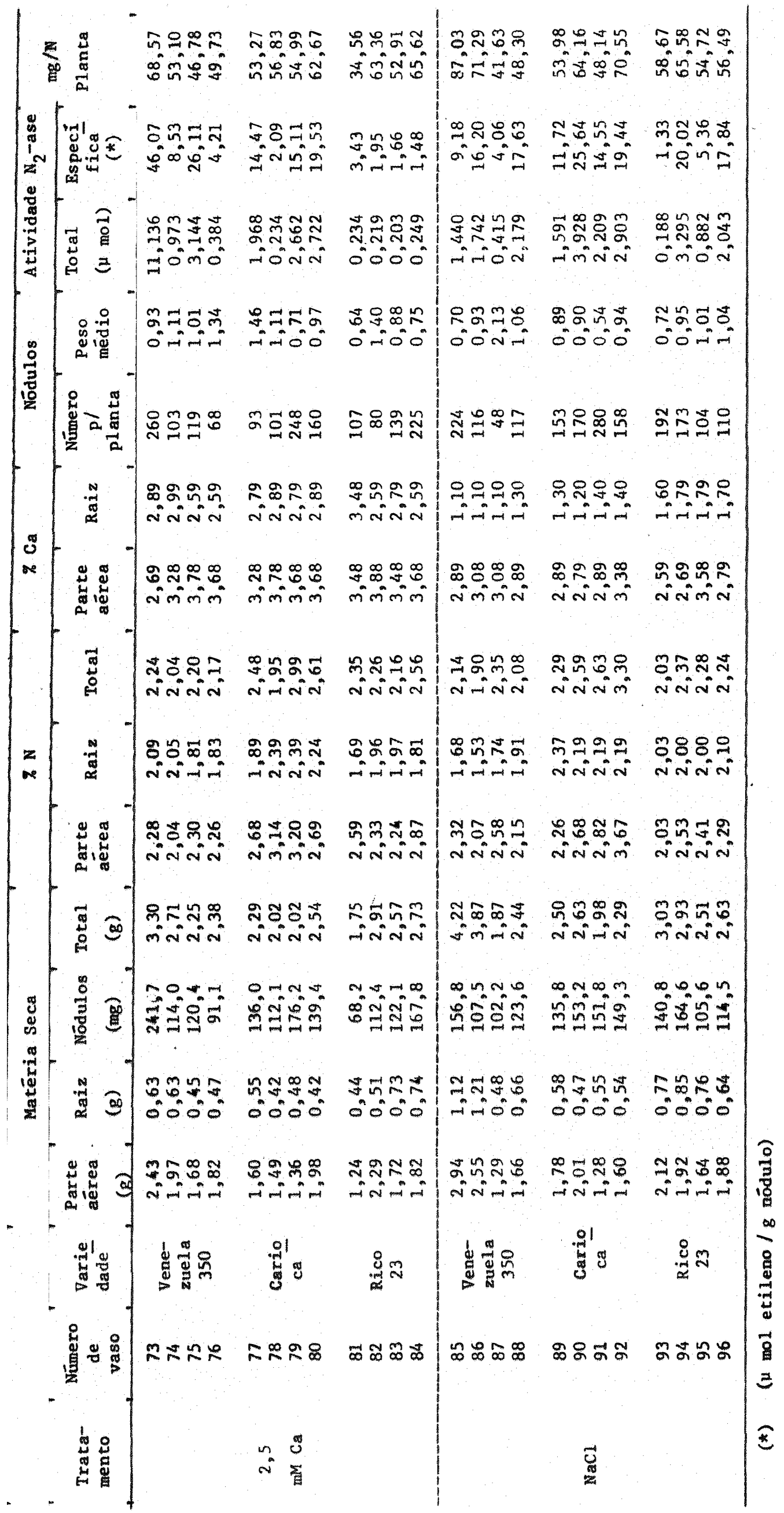




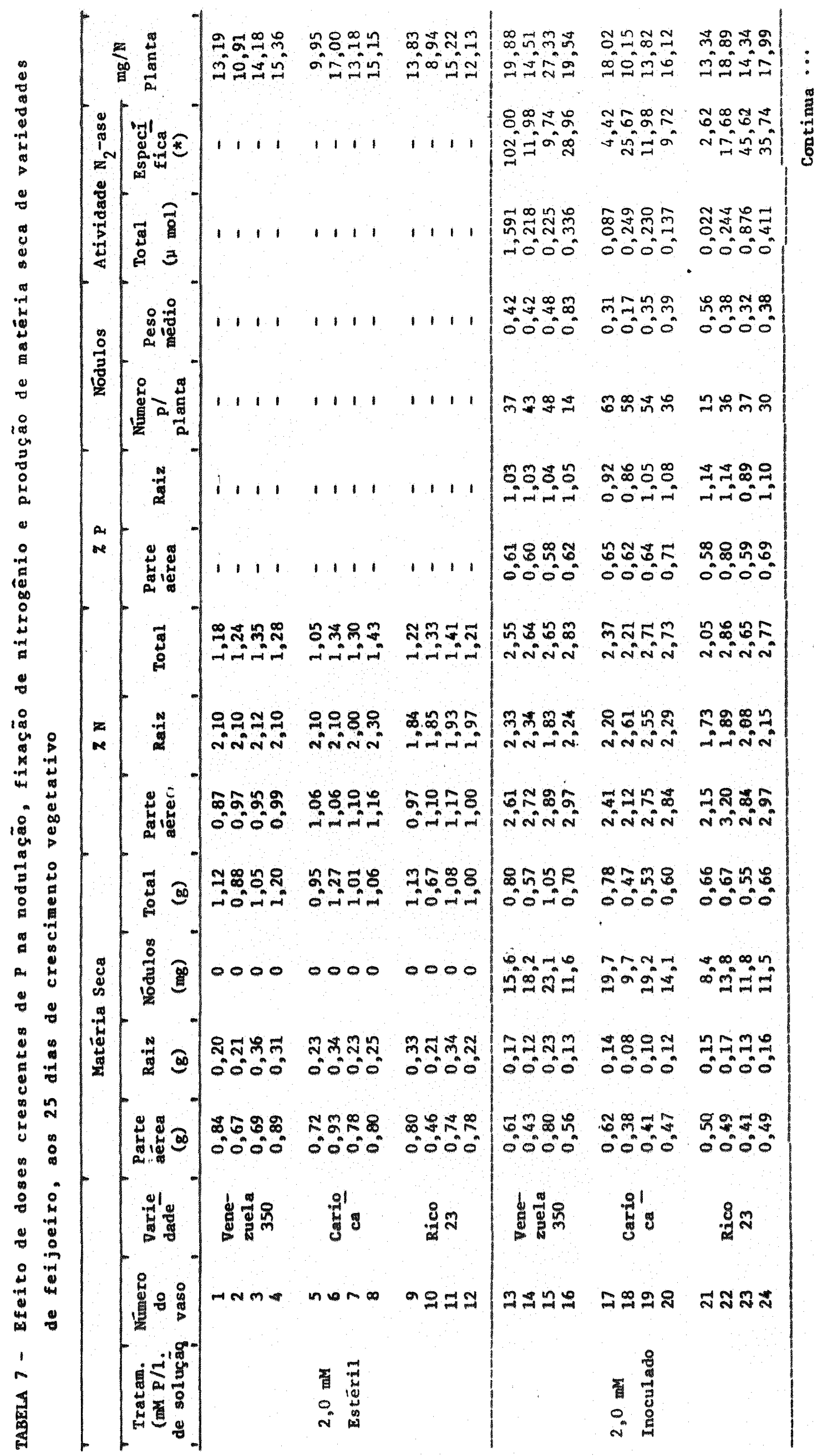




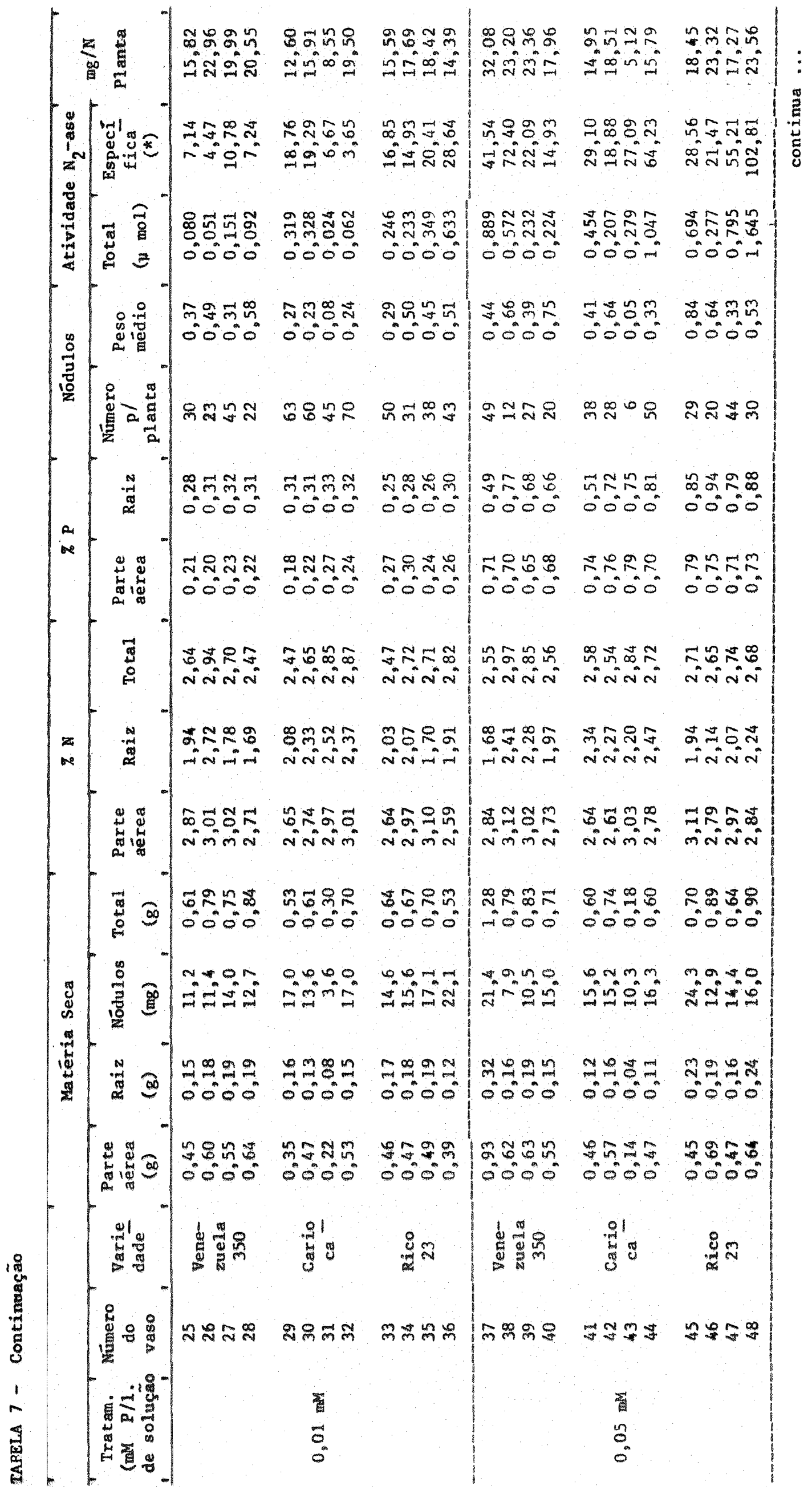




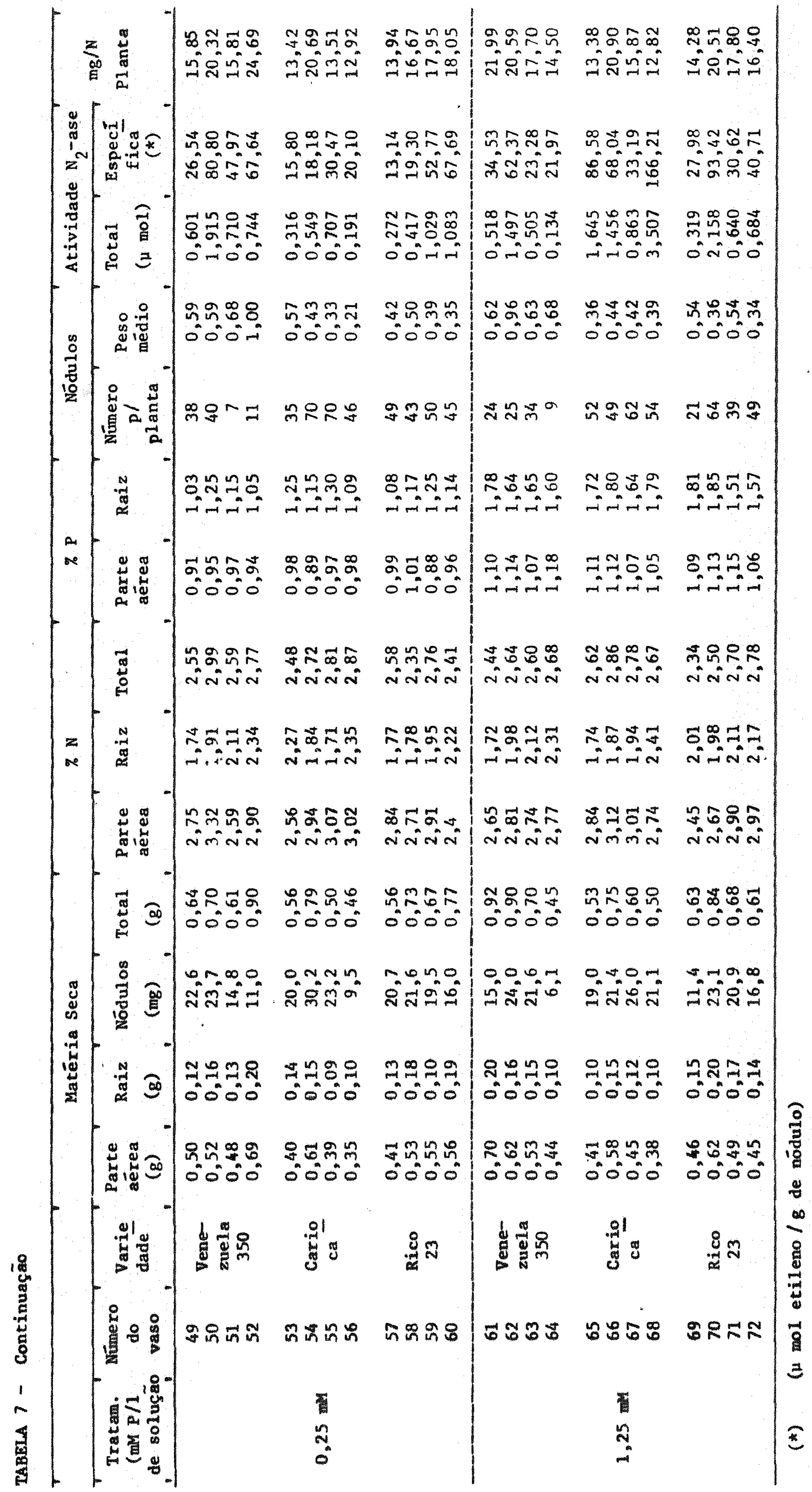




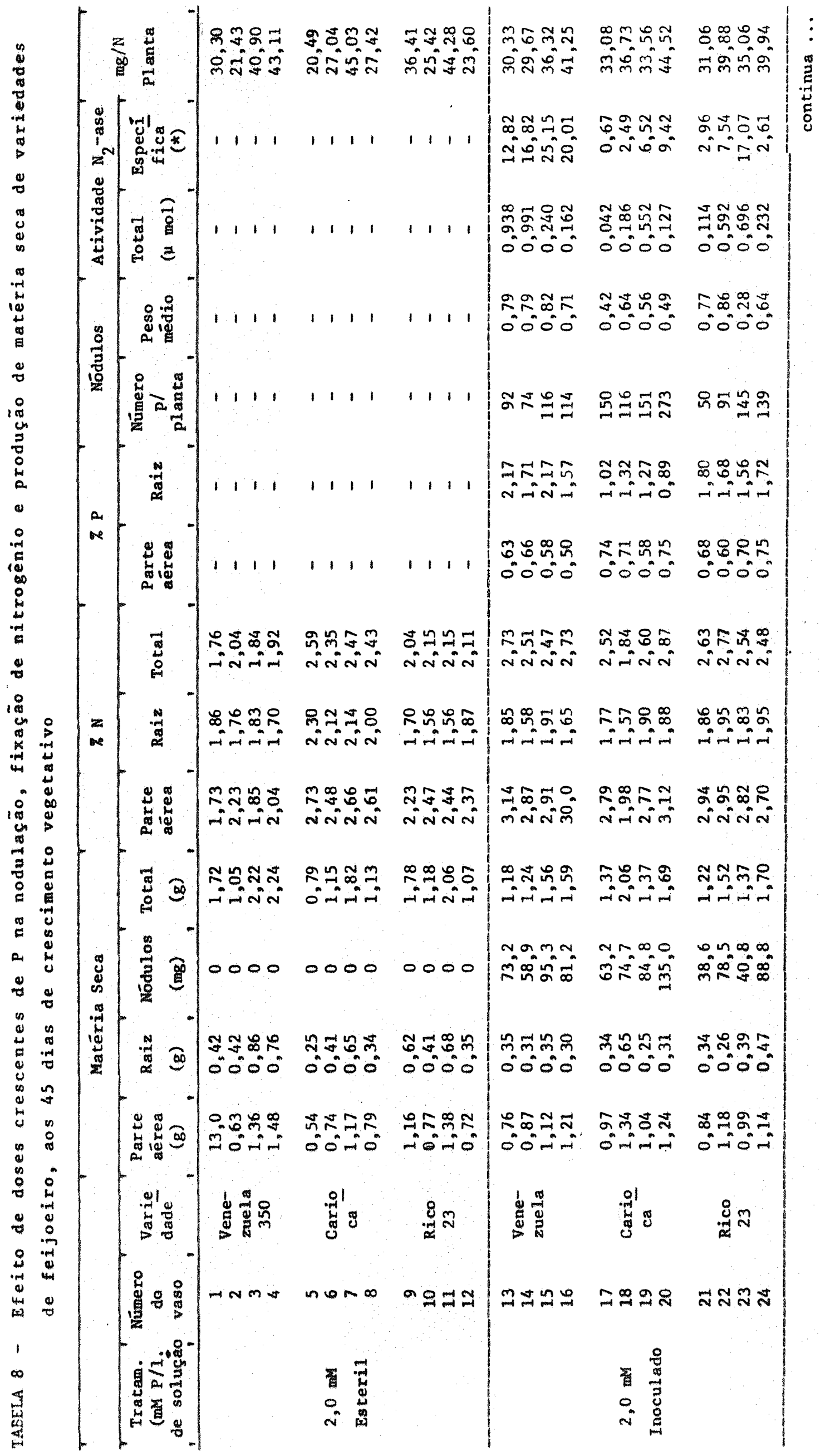




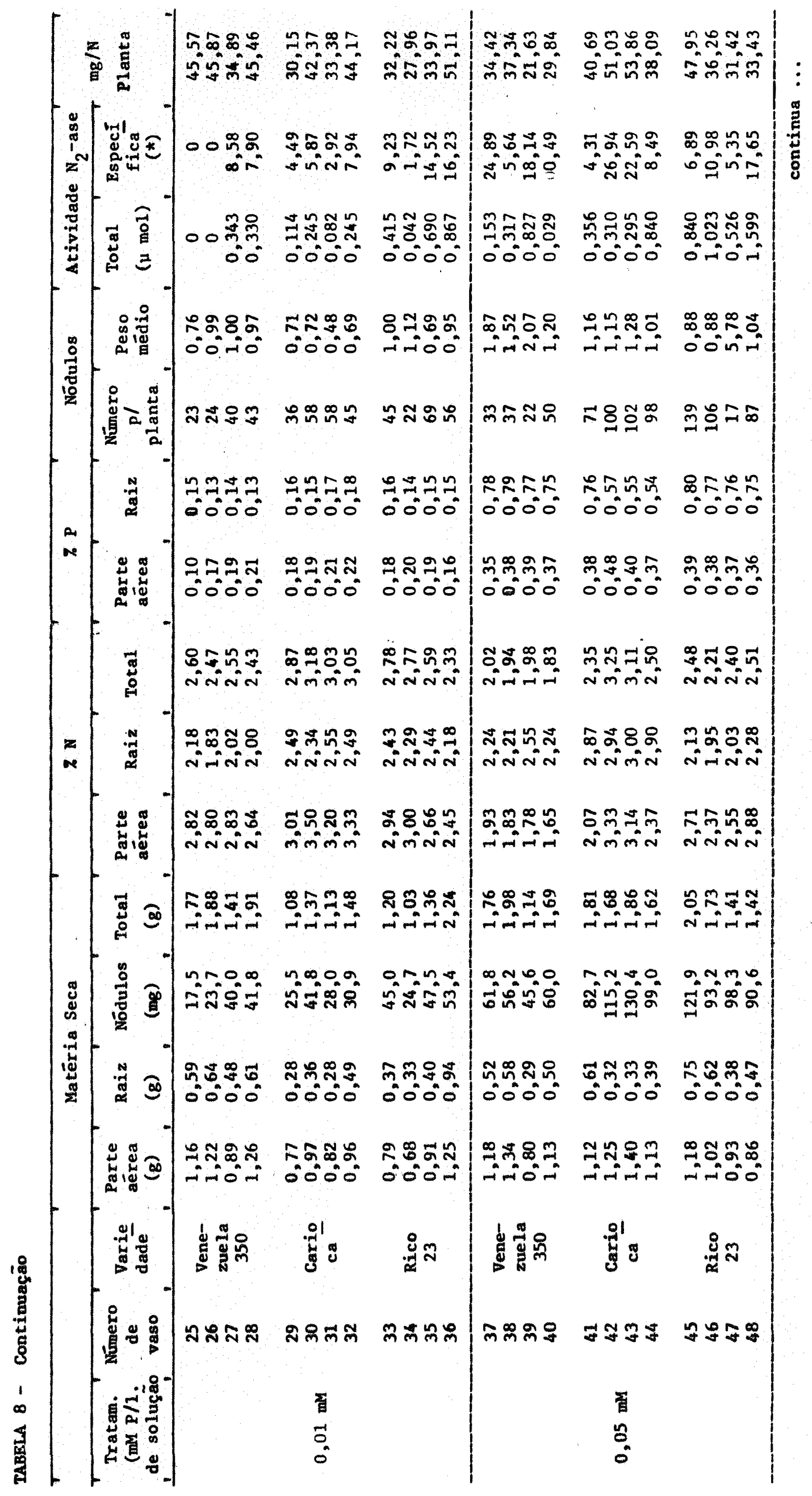




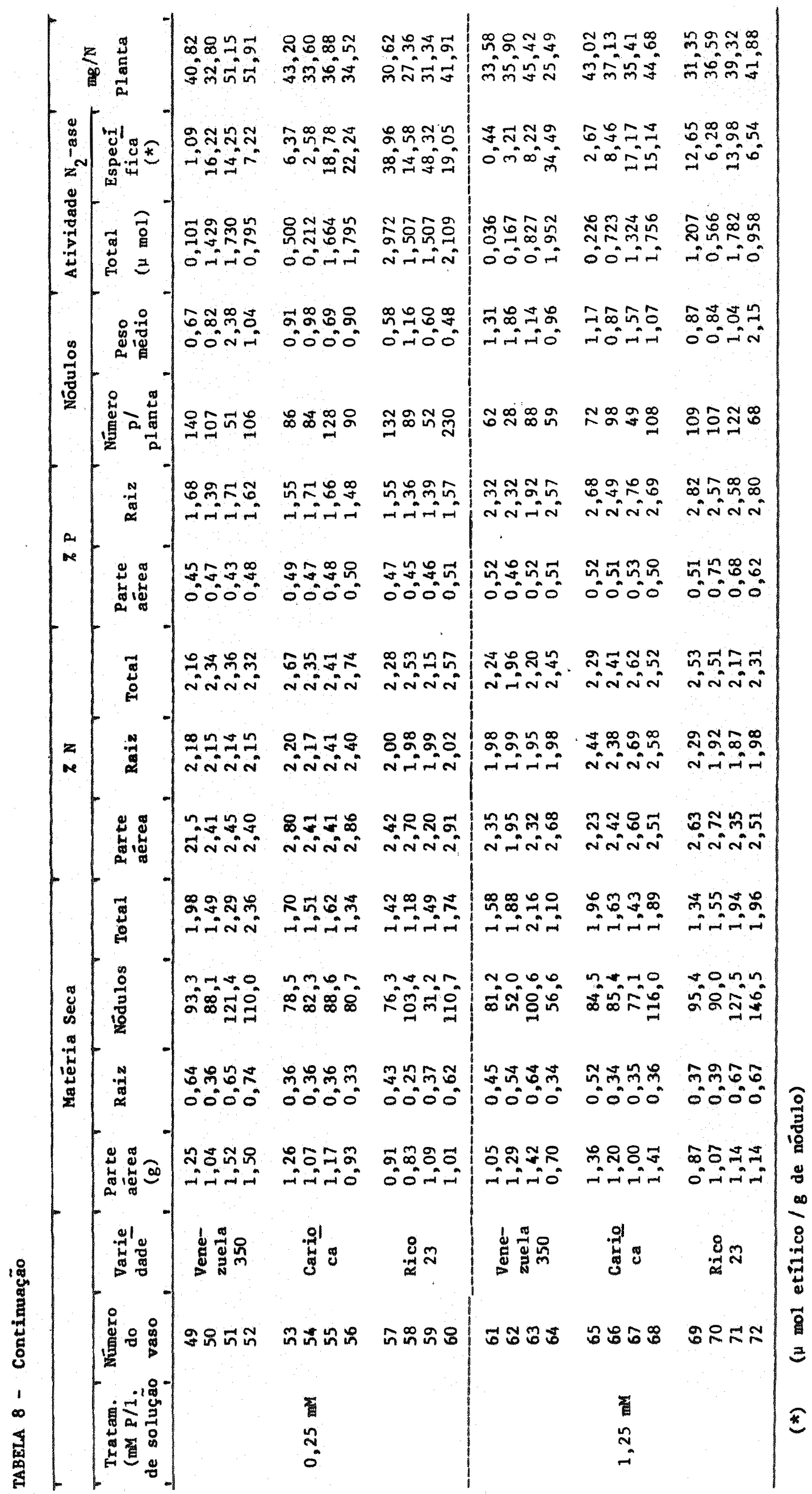




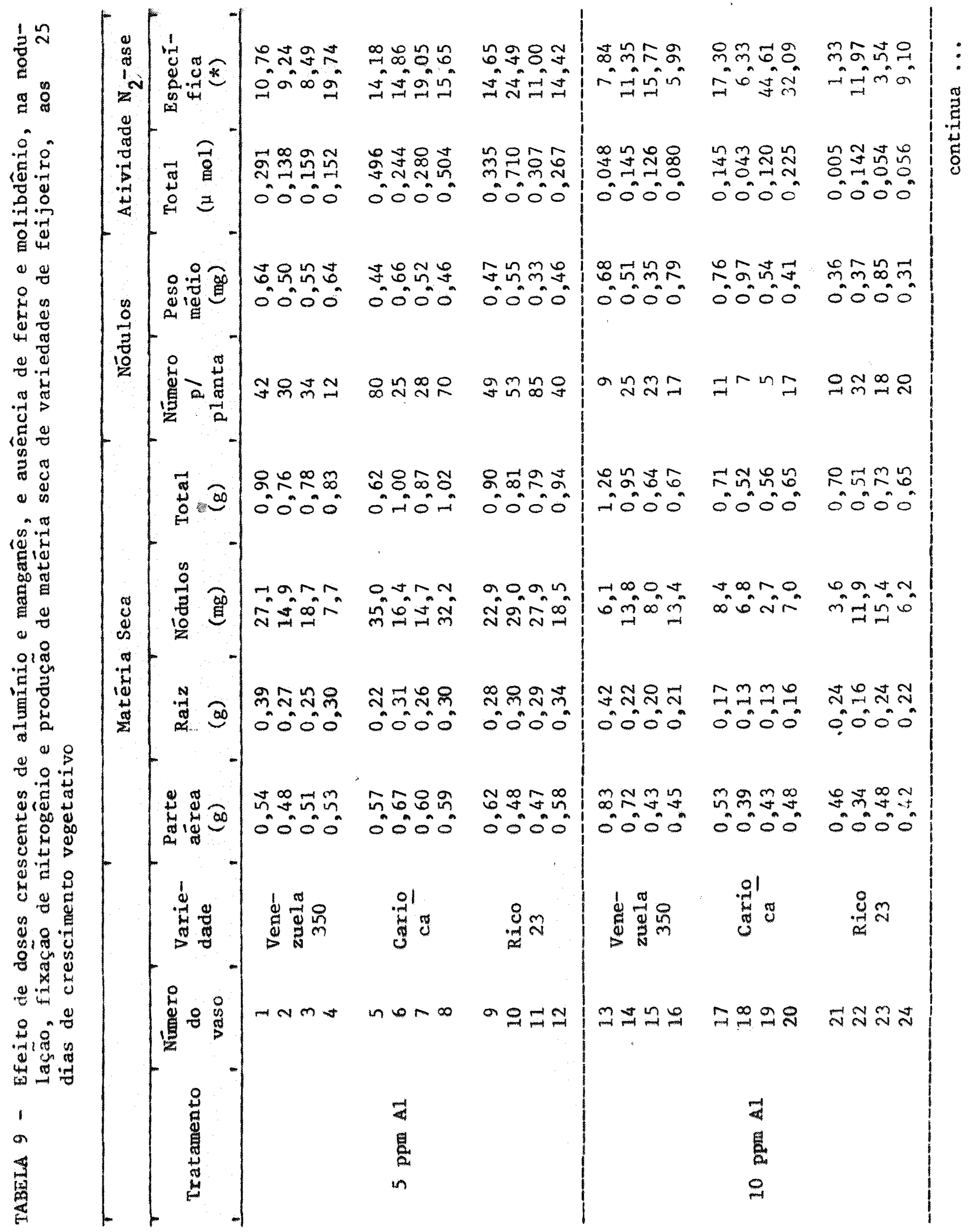




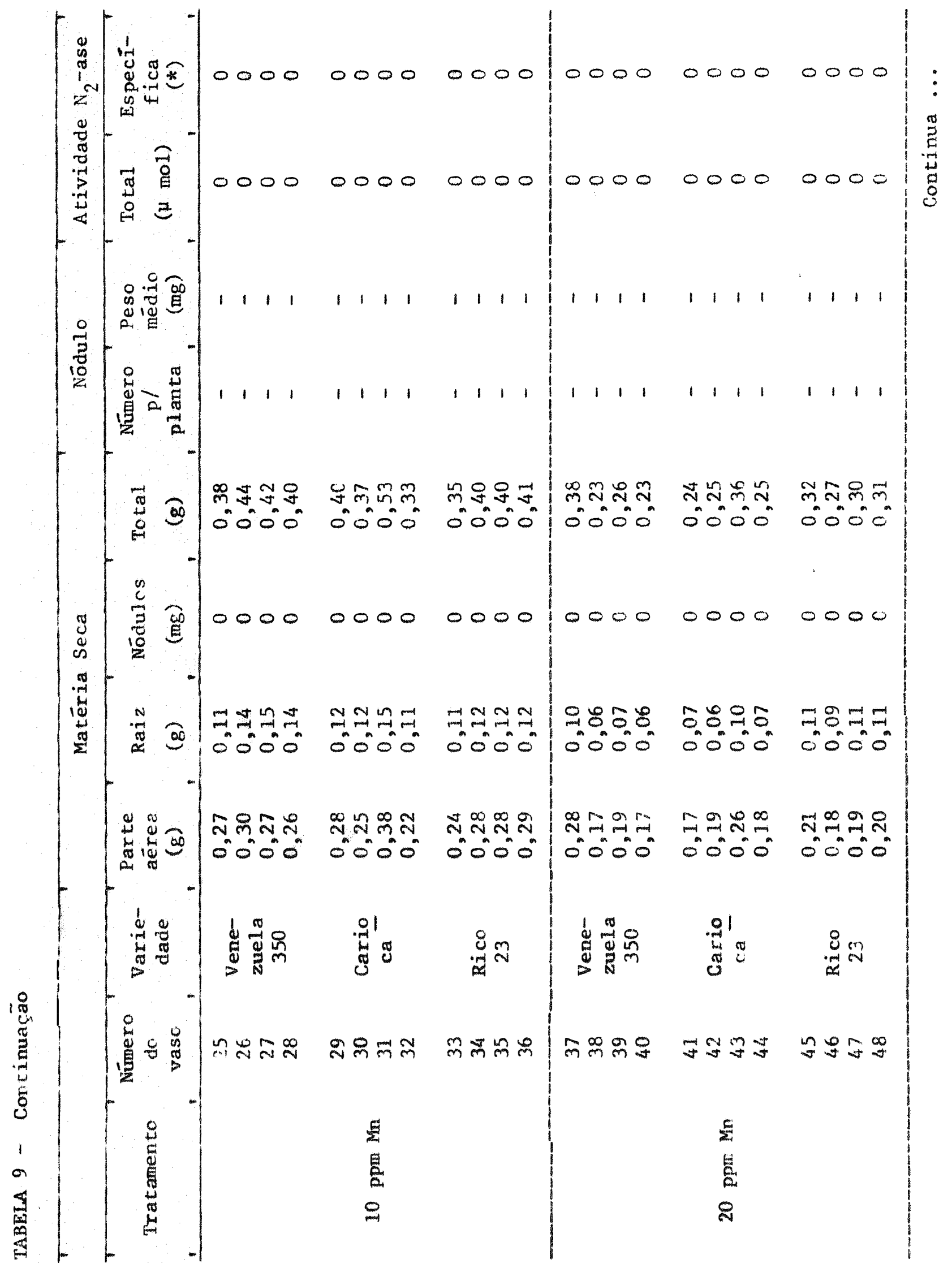




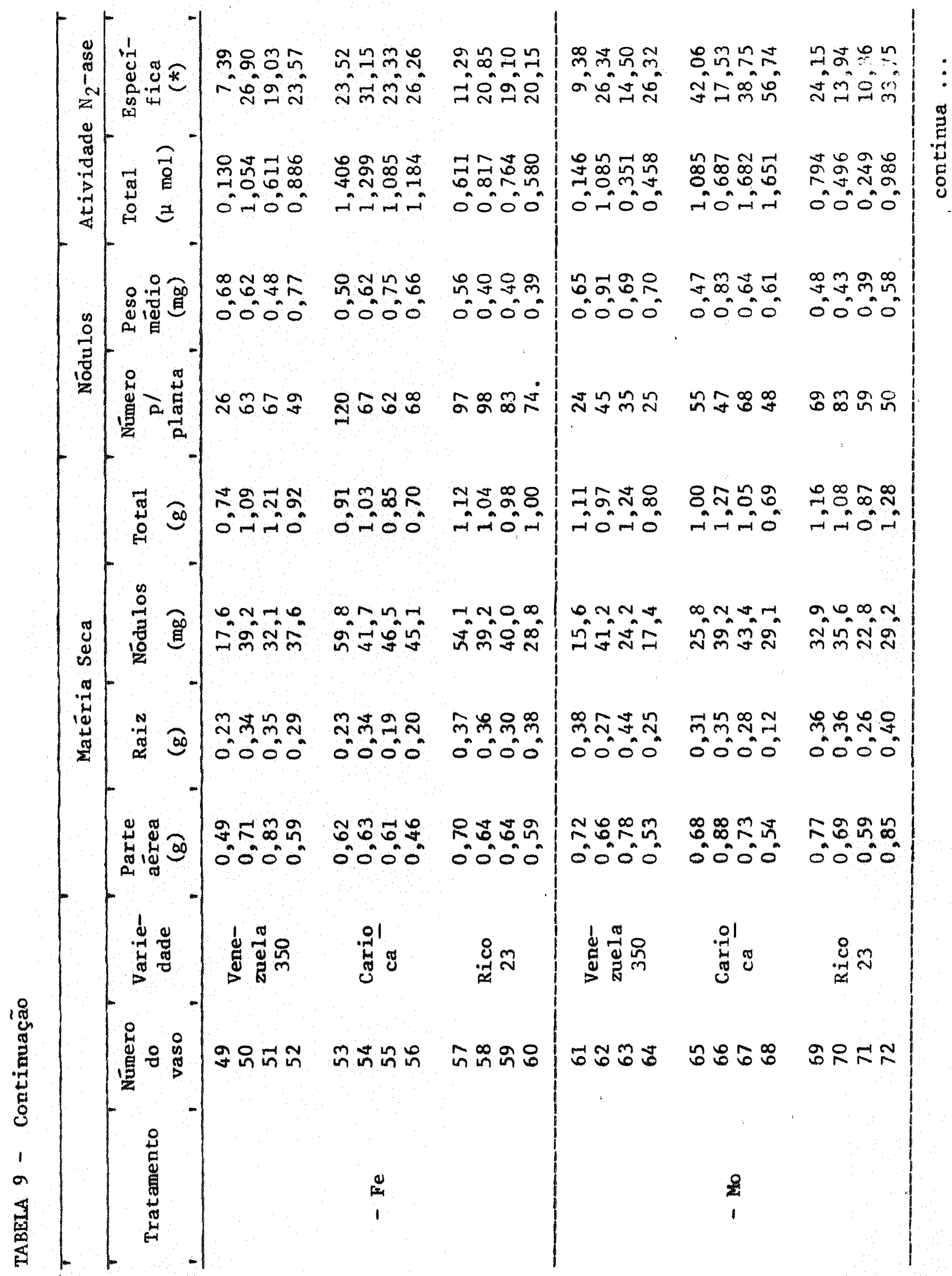




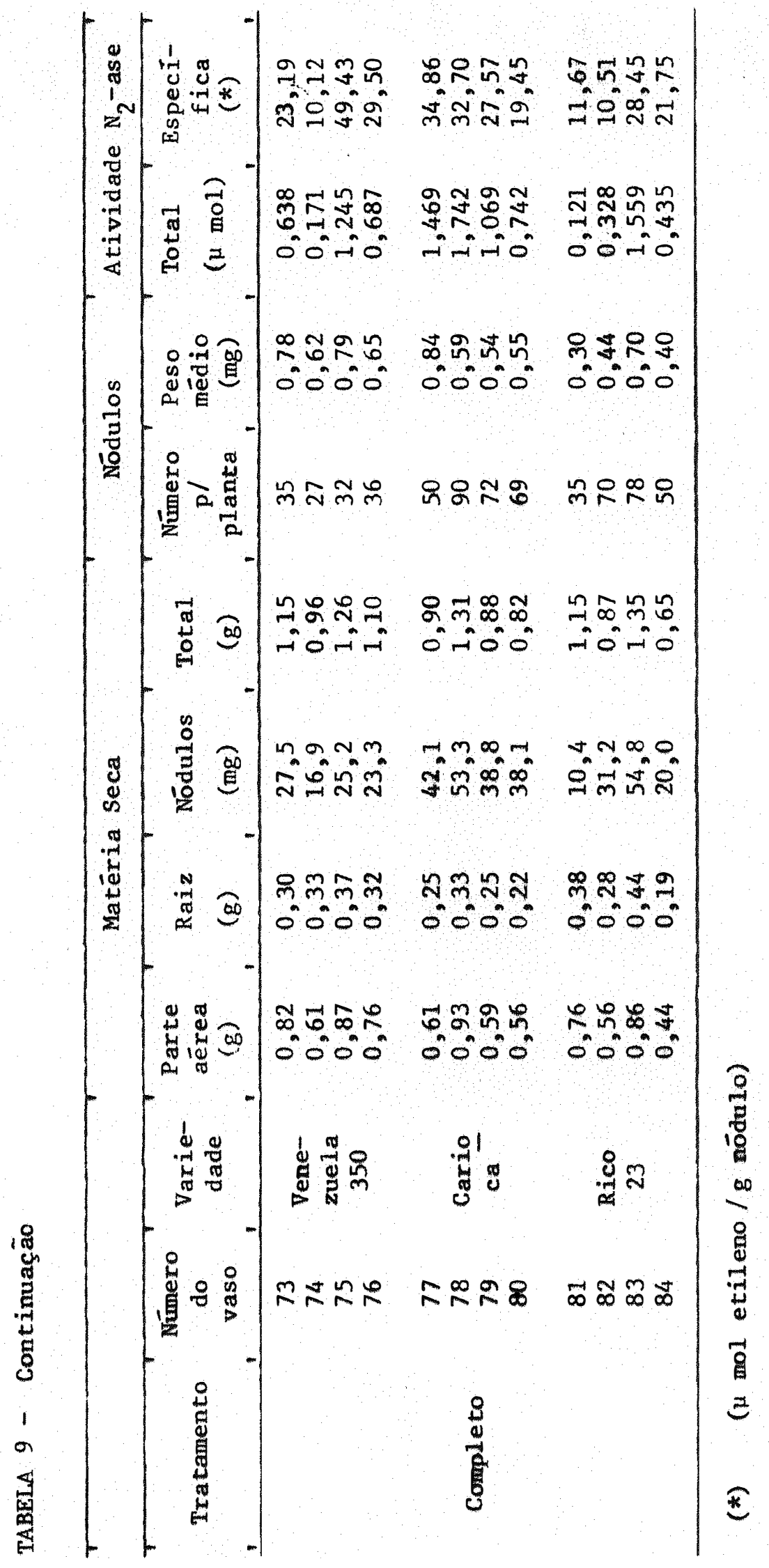




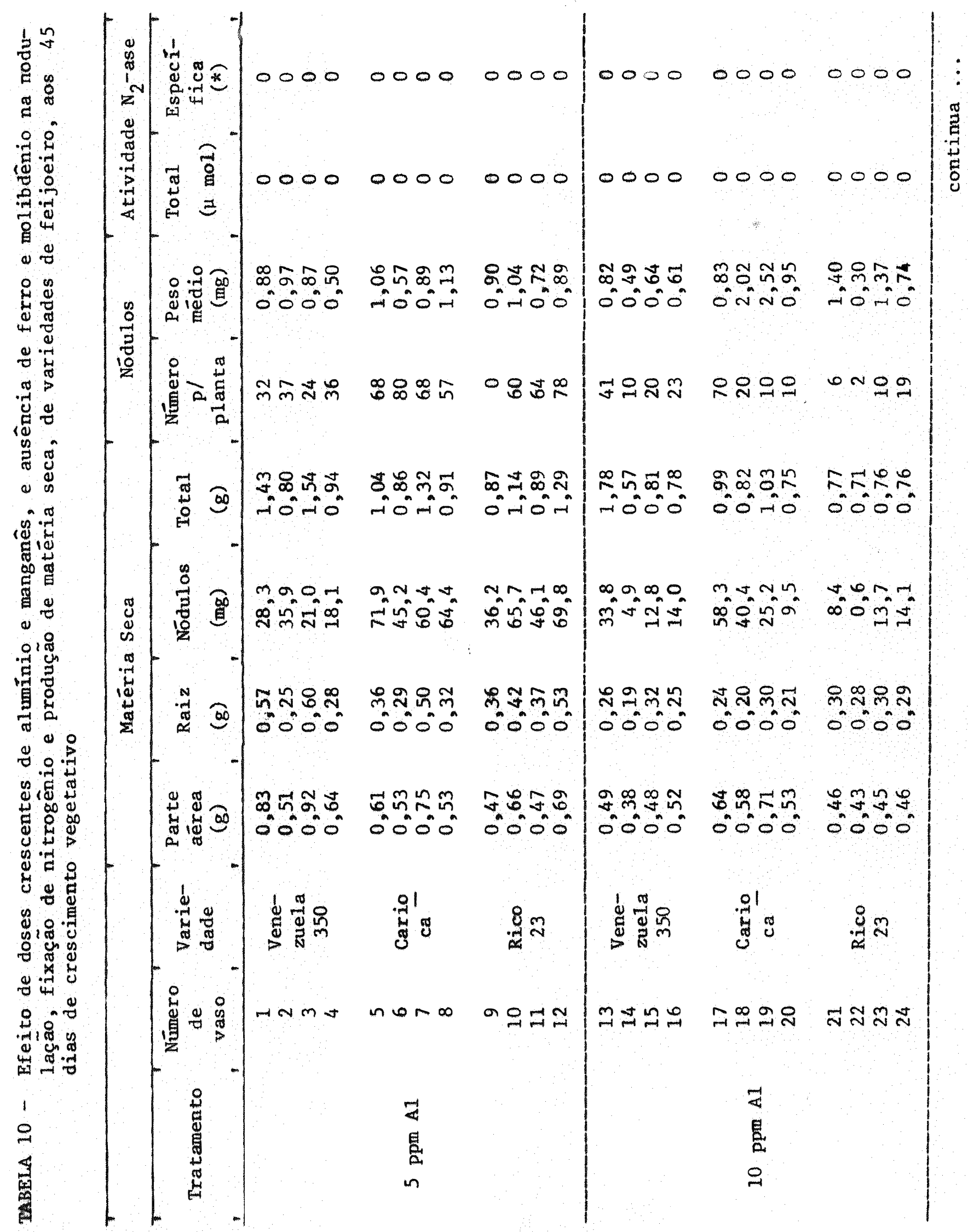




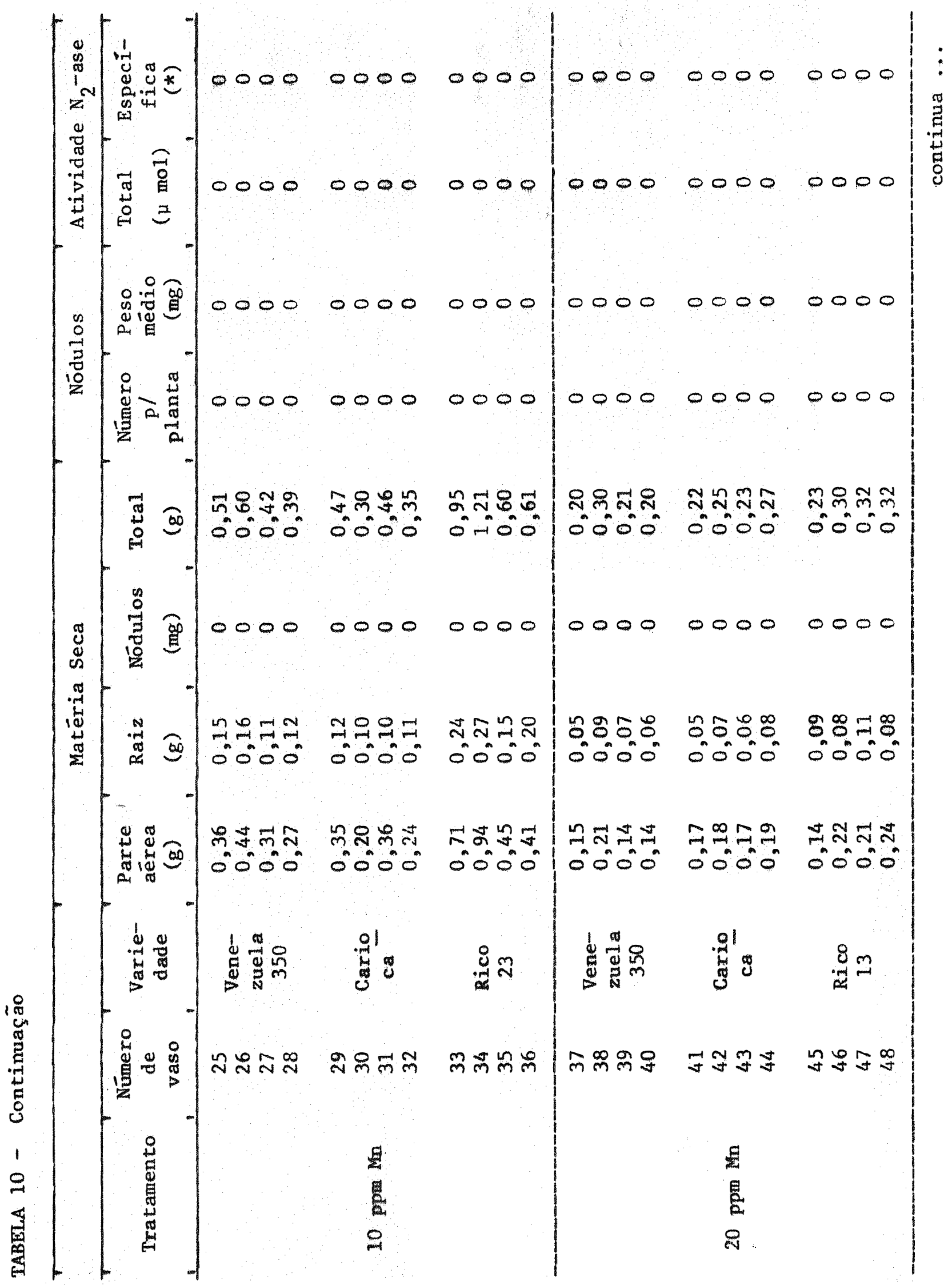




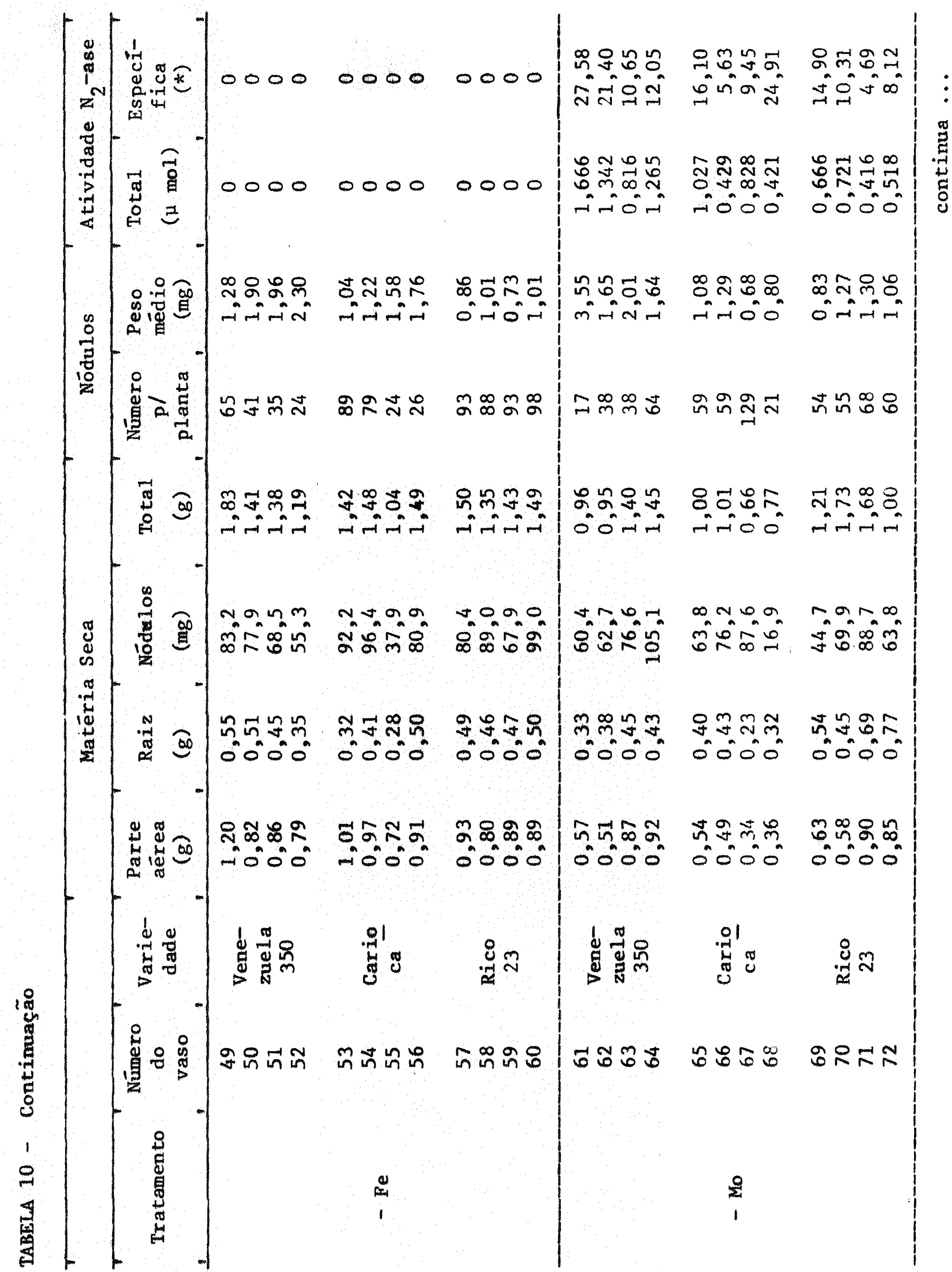




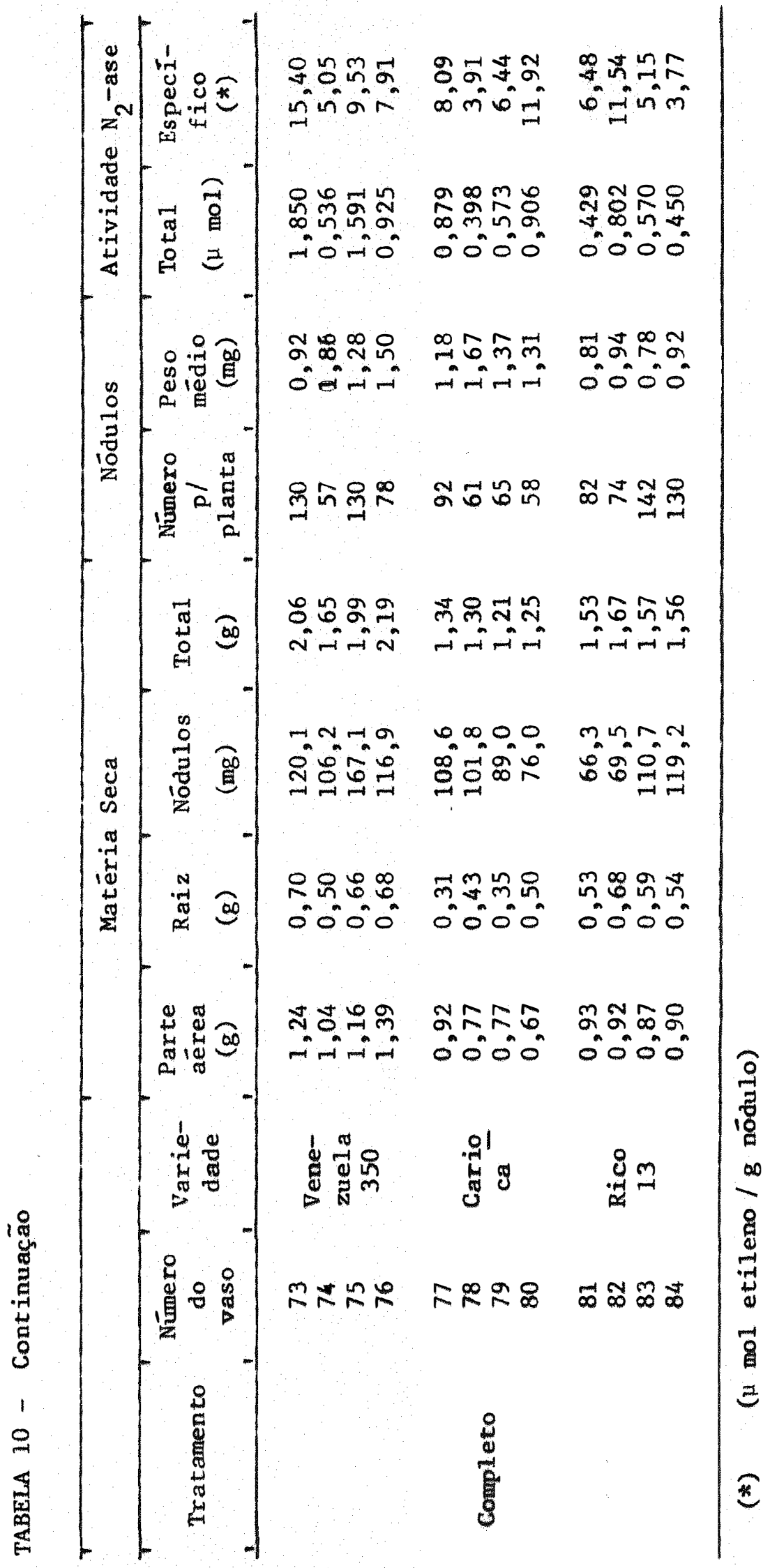

